UNIVERSIDADE DE SÃO PAULO

CAMPUS DE SÃO CALOS

\title{
ESTUDO DOS ATRIBUTOS DO MEIO FÍSICO COMO BASE PARA O ZONEAMENTO GEOAMBIENTAL DA REGIÃO DE INFLUÊNCIA DO RESERVATÓRIO DA USINA HIDROELÉTRICA DE CACONDE (SP), ESCALA: 1:50.000, COM USO DE GEOPROCESSAMENTO
}

Holden Robson de Amorim

\begin{abstract}
Dissertação apresentada à Escola de Engenharia de São Carlos da Universidade de São Paulo, para concorrer ao Título de Mestre, pelo curso de PósGraduação em Engenharia Civil - Área de concentração: Geotecnia.
\end{abstract}

São Carlos 
UNIVERSIDADE DE SÃO PAULO

CAMPUS DE SÃO CALOS

\title{
ESTUDO DOS ATRIBUTOS DO MEIO FÍSICO COMO BASE PARA O ZONEAMENTO GEOAMBIENTAL DA REGIÃO DE INFLUÊNCIA DO RESERVATÓRIO DA USINA HIDROELÉTRICA DE CACONDE (SP), ESCALA: 1:50.000, COM USO DE GEOPROCESSAMENTO
}

Holden Robson de Amorim

\begin{abstract}
Dissertação apresentada à Escola de
Engenharia de São Carlos da

Universidade de São Paulo, para concorrer ao Título de Mestre, pelo curso de PósGraduação em Engenharia Civil - Área de concentração: Geotecnia.
\end{abstract}

Orientador: Prof. Dr. Osni José Pejon

São Carlos 


\section{Candidato: Geólogo HOLDEN ROBSON DE AMORIM}

Dissertação defendida e julgada em 19-05-2003 perante a Comissão Julgadora:

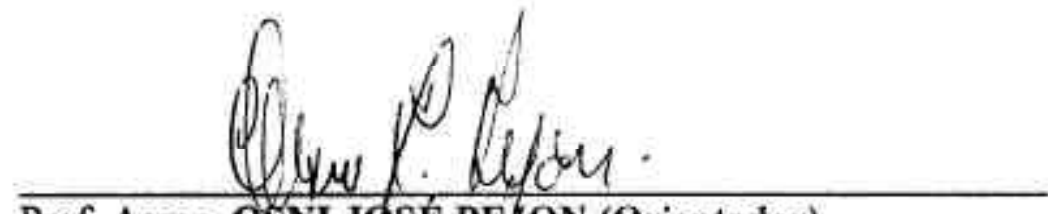

Prof. Assoc. OSNI JQSSÉ PE JON (Orientador)

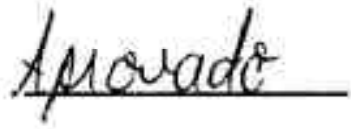

(Escola de Engenharia de São Carlos/USP)

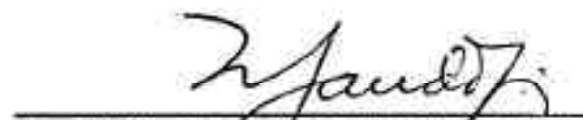

Prof. Tit. NI/S 0 N GANDOLFI

(Escola de Entenhatria de São Carlos/USP)

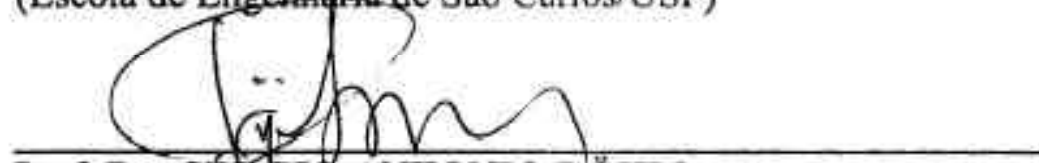

Prof. Dr. SÉRिIO ANTONIO RÖHM

(Universidade Federal de São Carlos/UFSCar)
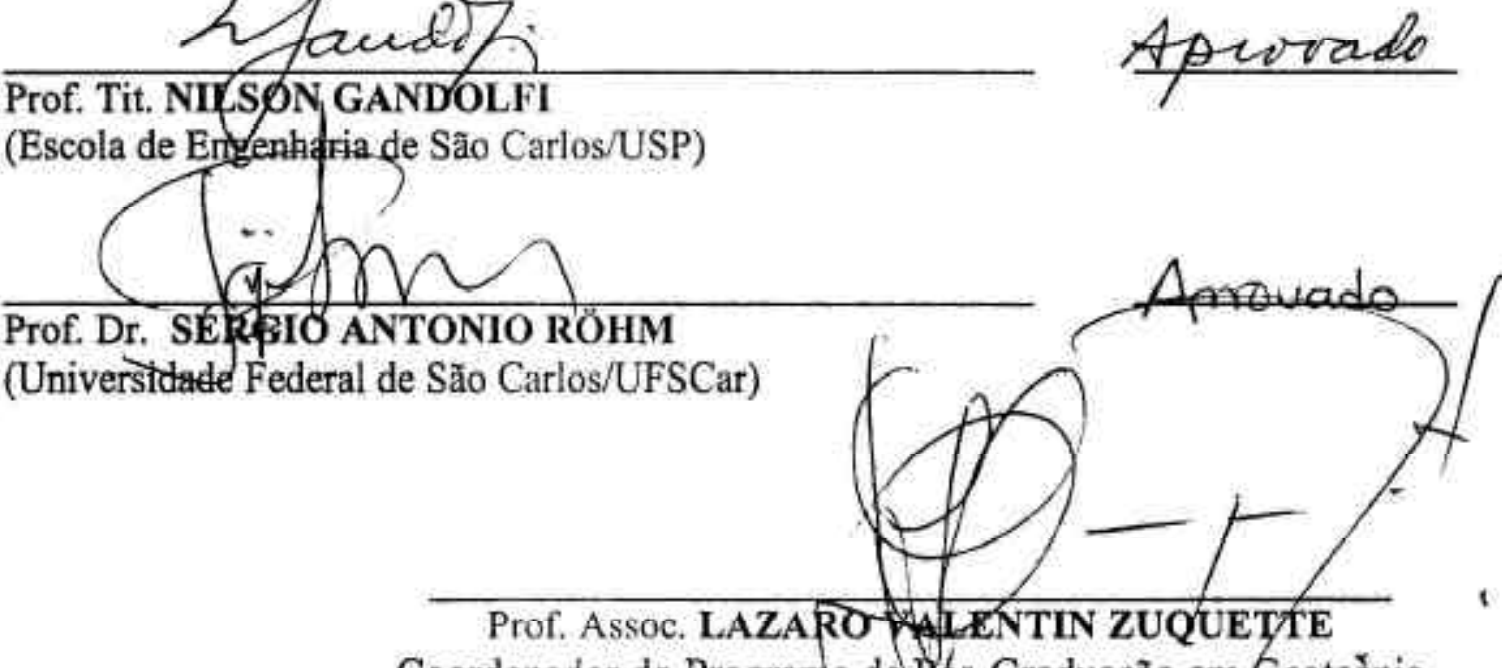

Coordenador do Programa de Pós-Graduação em Geotečnia
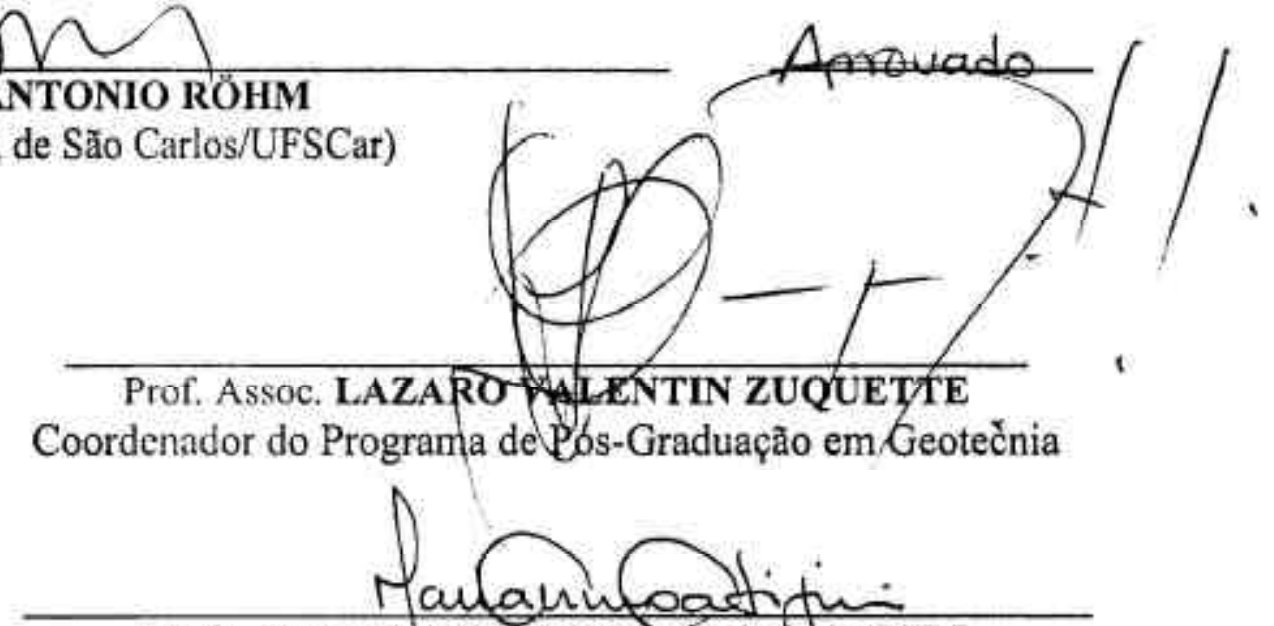

Profa. Assoc. MARIA DO CARMO CALIJURI

Presidente da Comissão de Pós-Graduação da EESC 
Aos meus pais, Pedro e Suely Amorim, e ao meu irmão Rafael Amorim. 


\section{AGRADECIMENTOS}

A DEUS por sua presença constante em minha vida, dando-me saúde e principalmente sabedoria nos momentos que mais preciso.

Aos meus pais, Pedro e Suely Amorim, e ao meu irmão Rafael Amorim por preencherem de amor o coração do seu filho e irmão que tão longe esteve de casa.

Ao professor Dr. Osni José Pejon pela amizade, dedicação, estimulo e a rica orientação conferida.

A Lidiane Freire por seu amor e por sempre me fazer acreditar que conseguiria conquistar meus objetivos na vida.

Ao geólogo Msc. Jaime Colares e aos professores Dr. Nilson Gandolfi e Dr. César Veríssimo pela amizade e pelo auxilio no ingresso no programa de pósgraduação da USP.

Aos amigos que deixei em Fortaleza e que não esqueceram do amigo em São Carlos: Claúdio Petroccelli, Gustavo Moser e Ulisses Júnior.

Aos primeiros amigos que fiz na cidade, Wilson Cartaxo e Fábio Lopes, pela amizade e companheirismo.

Aos amigos, moradores da República Tijolinho, também pela amizade e

companherismo: Éverton ("Monstro"), João Fernando, Tibério (“Tibas”), Fábio Lavor ("Fabão"), Jorge, Iran, Vinícius, Carlos Alberto ("Kaito”), Douglas, André Coelho (“Jabuti”), André (“Andrezão") e Alisson.

Aos amigos, também moradores do Tijolinho, Sérgio Brasil ("Bolacha”) e Sérgio Siebra ("Tio Roy”) pela enorme amizade e generosidade.

A Jocy ("Moagem"), Kleber ("Baiano") e Luiz Barras também pelo mesmo motivo: amizade e generosidade. 
A Helano Fonteles, grande amigo e conselheiro, pela ajuda e amizade em todos os momentos tanto em Fortaleza quanto em São Carlos.

As minhas amigas Sara Fernada e Indira Macambira pela grande amizade e por sempre estarem dispostas a ouvir o amigo.

A Silvana Brandão pela amizade e enorme ajuda no desenvolvimento dessa dissertação.

Aos amigos da Geo: Dirlene, Célio, Vinícius, Maurício, Paulo Maurício, Domingos, Jânio, Leonardo, Juliana, Gracinete (“Gracy”) e Rogério.

Ao "povo" do SHS: Geovani (“Cabeludo”), Romeu (“Tapuru”), Leonardo, Aurélio ("Besta"), Hélio ("Negão") e João ("Deformado").

Aos professores do Departamento: Zuquette, Paraguassu, Zé Eduardo e Orêncio.

A USP e a CAPES pela excelente infra-estrutura e apoio financeiro para realização desse mestrado.

Enfim, a todos aqueles que participaram da minha vida nesse período, dos quais muitos me farão sentir saudades ... 
Foi numa cidade do interior de São Paulo São Carlos ...

(Trecho inicial da canção "A Miragem", composta pela República Tijolinho, que conta a árdua trajetória de um estudante de mestrado da USP de São Carlos) 


\section{SUMÁRIO}

LISTA DE FIGURAS.................................................................................. i

LISTA DE TABELAS............................................................................... vi

LISTA DE ABREVIATURAS E SIGLAS........................................................ xii

LISTA DE SÍMBOLOS................................................................................ xiii

RESUMO_................................................................................................................ xiv

SUMMARY / ABSTRACT....................................................................................... $\quad \mathrm{xv}$

1 INTRODUÇÃ

1.1 Objetivos................................................................................................... 2

2 REVISÃO BIBLIOGRÁFICA................................................................. 3

2.1 Bacias Hidrográficas................................................................................................. 3

2.1.1 Definição, Tipos e Padrões de Drenagem....................................................... 3

2.1.2 A Bacia Hidrográfica como Limite Territorial para o Planejamento e

Gerenciamento Ambiental.............................................................................. 6

2.2 Estudos Geoambientais............................................................................................. 9

2.2.1 Motivações................................................................................................ 9

2.2.2 Desenvolvimento Sustentado e Gestão Ambiental........................................... 10

2.2.3 Geoambiente e a Ação Antrópica.................................................................... 14

2.2.4 Exemplos de Metodologias Desenvolvidas em Estudos Geoambientais.... 16

2.3 Geoprocessamento.................................................................................................. 26

2.3.1 Sistemas de Informação Geográfica................................................................. 26

2.4 Análise de Agrupamentos de Informações Geoambientais (Cluster Analysis) ............................................................................................................ 31

3 MATERIAIS E MÉTODOS...................................................................... 32 
3.1 Métodos de Trabalho.............................................................................................. 32

3.1.1 Trabalhos de Gabinete................................................................................. 32

3.1.2 Trabalhos de Campo............................................................................................... 35

3.1.3 Trabalhos de Laboratório................................................................... 35

3.2 Materiais Utilizados.......................................................................................... 37

4 CARACTERIZAÇÃO GERAL DA ÁREA EM ESTUDO................................ 39

4.1 Localização, Tamanho da Área e Acesso........................................................ 40

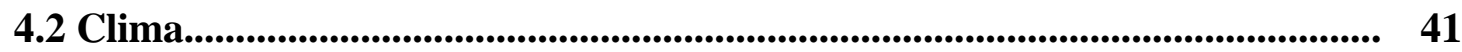

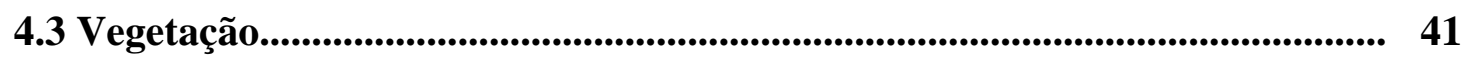

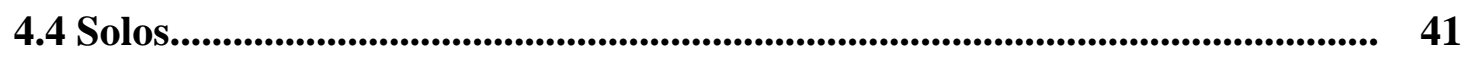

4.5 Geomorfologia..................................................................................................................... 41

4.6 Geologia Regional............................................................................................................. 42

4.7 Aspectos Sócio-econômicos.......................................................................................... 43

5 OBTENÇÃO DOS DADOS, TRATAMENTO E ANÁlise DAS INFORMAÇÕES................................................................................................ 44

5.1 Documentos Cartográficos Elaborados....................................................... 44

5.1.1 Mapa de Documentação.............................................................................. 44

5.1.2 Carta de Declividades........................................................................... 46

5.1.3 Mapa de Substrato Rochoso........................................................................... 53

5.1.4 Mapa de Materiais Inconsolidados.......................................................... 61

5.1.5 Mapa de Landforms......................................................................................... 89

5.1.6 Mapa de Uso e Ocupação................................................................................... 111

5.1.7 Carta de Potencial Agrícola........................................................................ 118

5.2 Sistemas de Bancos de Dados Associados aos Documentos Cartográficos

Produzidos em Ambiente SIG.......................................................................... 128

5.2.1 Construção do Banco de Dados Baseados em Registros Pontuais............. 129

5.2.2 Construção do Banco de Dados a Partir dos Documentos Cartográficos Elaborados..................................................................................................... 130

5.2.3 Alguns Exemplos de Operações que Podem Ser Realizadas Utilizando os Bancos de Dados e os Documentos Cartográficos Produzidos......................................................................................................... 131

6 CARTA DE ZONEAMENTO GEOAMBIENTAL............................................ 138 
6.1 Definição e Finalidades da Carta de Zoneamento Geoambiental................... 138

6.2 Elaboração da Carta de Zoneamento Geoambiental........................................ 138

6.3 Análise das Aptidões e das Situações de Uso e Ocupação do Meio Físico nas Unida des Geoambientais................................................................................... 147

6.3.1 Aptidões do Meio Físico nas Unidades Geoambientais................................. 147

6.3.2 Situação do Uso e Ocupação do Meio Físico nas Unidades Geoambientais................................................................................................... 149

7 CONCLUSÕES E RECOMENDAÇÕES....................................................... 159

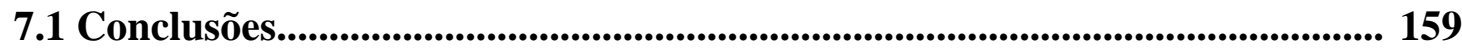

7.1.1 Quanto a Metodologia de Zoneamento Geoambiental................................. 159

7.1.2 Quanto ao Geoprocessamento das Informações............................................... 160

7.1.3 Quanto aos Resultados Obtidos no Zoneamento Geoambiental................. 160

7.2 Recomendações.......................................................................................... 161

REFERÊNCIAS BIBLIOGRÁFICAS............................................................ 162

ANEXO I - MAPA DE DOCUMENTAÇÃO

ANEXO II - CARTA DE DECLIVIDADES

ANEXO III - MAPA DE SUBSTRATO ROCHOSO

ANEXO IV - MAPA DE MATERIAIS INCONSOLIDADOS

ANEXO V - MAPA DE LANDFORMS

ANEXO VI - MAPA DE USO E OCUPAÇÃO

ANEXO VII - CARTA DE POTENCIAL AGRÍCOLA

ANEXO VIII - CARTA DE ZONEAMENTO GEOAMBIENTAL

ANEXO IX - RELAÇÃO ENTRE AS UNIDADES DE TERRENO E OS DIVERSOS ATRIBUTOS DO MEIO FÍSICO LEVANTADOS

ANEXO X - RELAÇÃO ENTRE AS UNIDADES GEOAMBIENTAIS E OS DIVERSOS ATRIBUTOS DO MEIO FÍSICO LEVANTADOS 


\section{LISTA DE FIGURAS}

FIGURA 2.1 Bacia hidrográfica, fluxos e transformações de energia, água e sedimentos...

FIGURA 2.2 Disposição espacial dos principais tipos de padrão de drenagem (Fonte: Christofoletti, 1974).......................................

FIGURA 2.3 Principais usos do solo e possíveis interferências nos recursos hídricos (Fonte: Pires \& Santos, 1995)

FIGURA 2.4 Representação esquemática das relações e interações no geoambiente (Modificado de Aswathanarayana, 1995)

FIGURA 2.5 Carta de aptidão a disposição de resíduos sólidos (Fonte: Dai et al., 2001)

FIGURA 2.6 Cartas geotécnicas produzidas para a região de Piracicaba (SP).

FIGURA 2.7 Cartas geotécnicas produzidas para as bacias dos Rio Passa Cinco e Rio da Cabeça, ambos afluentes da margem direita do Rio Corumbataí (SP).

FIGURA 2.8 Estrutura geral de sistemas de informação geográfica. (Fonte: Davis \& Câma ra, 1999).

FIGURA 3.1 Fluxograma mostrando as diversas interações entre as etapas de trabalho executadas na pesquisa................................. 34

FIGURA 3.2 Ficha de campo utilizada na pesquisa.............................................. 36

FIGURA 4.1 Localização da área em estudo........................................................ 40

FIGURA 5.1 Etapas seguidas para a construção do Mapa de Documentação. 
FIGURA 5.2 Hierarquização da rede hidrográfica e digitalização em diferentes camadas

FIGURA 5.3 Etapas seguidas para construção da Carta de Declividades.... 49

FIGURA 5.4 Utilização do filtro moda numa porção do MDT onde o grid é $3 \times 3$.

FIGURA 5.5 Aspecto da declividade antes e depois da utilização do filtro $\operatorname{moda}(3 \times 3)$

FIGURA 5.6 Modelo digital de Terreno indicando o posicionamento espacial do Maciço Alcalino e do Complexo Varginha gerado a partir do software ArcView ${ }^{\circledR} 3.1$

FIGURA 5.7 Migmatitos estromatíticos formando leitos intercalados nos migmatitos graníticos.

FIGURA 5.8 Fonólitos e nefelita sienitos, unidades do Maciço Alcalino que compõem o substrato rochoso da área estudada.

FIGURA 5.9 Etapas seguidas para a construção do Mapa de Substrato Rochoso

FIGURA 5.10 Etapas seguidas para a construção do Mapa de Materiais Inconsolidados

FIGURA 5.11 Adsorção de azul de metileno em função da porcentagem de argila dos materiais inconsolidados, mostrando o comportamento laterítico ou não laterítico, obtido com a classificação M.C.T. (Fonte: Pejon, 1992)

FIGURA 5.12 Diagrama de atividade das argilas pelo método do azul de metileno (Fonte: Pejon, 1992)

FIGURA 5.13 Ábaco para determinação do potencial expansivo (Fonte: Pejon, 2000)

FIGURA 5.14 Análise de agrupamentos entre as amostras de materiais inconsolidados (modo $Q)$ a partir dos resultados dos ensaios de granulometria conjunta. 
FIGURA 5.15 Curvas granulométricas das amostras pertencentes aos grupos texturais I, II, III e IV

FIGURA 5.16 Curvas granulométricas das amostras pertencentes aos grupos texturais V $\quad$ (A), $\quad$ VI $\quad$ (B), $\quad$ VII $\quad$ (C) (D).

FIGURA 5.17 Materiais inconsolidados pertencentes a Unidade 02.

FIGURA 5.18 Materiais inconsolidados pertencentes a Sub-unidade 03b. 73

FIGURA 5.19 Materiais inconsolidados pertencentes a Unidade 04............... 75

FIGURA 5.20 Materiais inconsolidados pertencentes a Unidade 07............... 77

FIGURA 5.21 Materiais inconsolidados pertencentes a Sub-unidade 10d...... 80

FIGURA 5.22 Materiais inconsolidados pertencentes a Sub-unidade 13b...... 83

FIGURA 5.23 Aplicação da técnica de avaliação de terreno, modificado de Cooke \& Doorkamp (1990) apud Lollo (1996)............................ 91

FIGURA 5.24 Imagem sombreada do relevo (gerada a partir do MDT no Surfer ${ }^{\circledR}$ 7.00) mostrando a localização dos Sistemas de terreno que compõem a área estudada.

FIGURA 5.25 Imagem sombreada do relevo mostrando a localização das unidades que compõem o Sistema de Terreno A......................... 94

FIGURA 5.26 Vista da Unidade A05............................................................. 95

FIGURA 5.27 Vista da Unidade A07..................................................................... 97

FIGURA 5.28 Vista da Unidade A08........................................................... 97

FIGURA 5.29 Imagem sombreada do relevo mostrando a localização das unidades que compõem o Sistema de Terreno B........................ 99

FIGURA 5.30 Vista da Unidade B01 ............................................................. 100

FIGURA 5.31 Imagem sombreada do relevo mostrando a localização das unidades que compõem o Sistema de Terreno C........................ 102

FIGURA 5.32 Imagem sombreada do relevo mostrando a localização das unidades que compõem o Sistema de Terreno D......................... 104

FIGURA 5.33 Vista da Unidade D01......................................................... 104

FIGURA 5.34 Vista da Unidade D02................................................................. 105

FIGURA 5.35 Vista da Unidade D04 ....................................................... 106 
FIGURA 5.36 Vista da Unidade D10................................................................. 107

FIGURA 5.37 Etapas seguidas para a construção do Mapa de Landforms..... 108

FIGURA 5.38 Análise de agrupamentos entre as Unidades de Terrenos (modo Q) presentes no Mapa de Landforms............................... 110

FIGURA 5.39 Etapas seguidas para a construção do Mapa de Uso e Ocupação....................................................................................... 112

FIGURA 5.40 Bandas 4, 5 e 3 do LANDSAT 5 sobrepostas ao MDT gerado para área estudada utilizando o ArcView ${ }^{\circledR} 3.1$............................ 113

FIGURA 5.41 Aparência das amostras de treinamento das classes de uso e ocupação da área estudada a partir das composições das bandas 4, 5 e 3 do LANDSAT 5.

FIGURA 5.42 Etapas seguidas para a construção do Carta de Potencial Agrícola

FIGURA 5.43 Planos de informações utilizados no Idrisi ${ }^{\circledR} 32$ para gerar a carta de potencial agrícola.

FIGURA 5.44 Etapas seguidas para a construção do mapa de documentação no Arc View GIS 3.1

FIGURA 5.45 Identificação das Unidades de Terreno com auxilio de hot link

FIGURA 5.46 Cálculo do comprimento dos canais fluviais através da função field calculator.

FIGURA 5.47 Função que ry builder utilizada na seleção de entidades do mapa de documentação (triângulos destacados em amarelo).. 135

FIGURA 5.48 Entidades numéricas selecionadas na tabela de pontos amostrados a partir da função que ry builder.

FIGURA 5.49 Unidades de Terreno (entidades alfanuméricas) selecionadas na tabela de landforms a partir da função que ry builder.

FIGURA 5.50 Função query builder utilizada na seleção de Unidades de Terreno no mapa de landforms (polígonos destacados em amarelo)

FIGURA 6.1 Etapas seguidas para a construção da Carta de Zoneamento Geoambiental. 
FIGURA 6.2 Análise de agrupamentos (modo Q) realizada a partir das superfícies ocupadas em cada unidade de terreno pelas classes/unidades de declividades, de potencial agrícola, de substrato rochoso e de materiais inconsolidados.

FIGURA 6.3 Análise de agrupamentos (modo Q) realizada a partir das superfícies ocupadas em cada unidade de terreno pelas classes/unidades de declividades, de potencial agrícola, de substrato rochoso e de materiais inconsolidados onde a distância euclidiana máxima atingida é igual a $100 \%$

FIGURA 6.4 Análise de agrupamentos (modo Q) realizada a partir das superfícies ocupadas em cada unidade geoambiental pelas classes/unidades de declividades, de potencial agrícola, de substrato rochoso e de materiais inconsolidados

FIGURA 6.5 Análise de agrupamentos (modo Q) realizada a partir das superfícies ocupadas em cada unidade geoambiental pelas classes/unidades de declividades, de potencial agrícola, de substrato rochoso e de materiais inconsolidados onde a distância euclidiana máxima atingida é igual a $100 \%$

FIGURA 6.6 Análise de agrupamentos (modo Q) realizada a partir das superfícies ocupadas pelas classes de potencial agrícola em cada unidade geoambiental.

FIGURA 6.7 Análise de agrupamentos (modo Q) realizada a partir das superfícies ocupadas em cada unidade geoambiental pelas classes de potencial agrícola onde a distância euclidiana máxima atingida é igual a $100 \%$

FIGURA 6.8 Regressão linear entre o percentual de superfícies ocupadas por café e o percentual de superfícies que apresentam solo exposto nas 21 Unidades Geoambientais analisadas 


\section{LISTA DE TABELAS}

TABELA 2.1 Instrumentos de gestão ambiental (Fonte: Bitar \& Ortega, 1998).

TABELA 5.1 Comparação entre vantagens e desvantagens na construção da carta de declividades por meios convencionais e computacionais.

TABELA 5.2 Parâmetros geométricos dos arquivos digitalizado e interpolado na construção do MNT.

TABELA 5.3 Resultados da distribuição das classes na Carta de Declividades após a utilização do filtro moda $(3 \times 3)$.

TABELA 5.4 Caracterização da amostra dos materiais inconsolidados que compõem a Unidade 02 quanto a sua localização, granulometria e índices físicos.

TABELA 5.5 Caracterização da amostra dos materiais inconsolidados que compõem a Unidade 02 pelo método de adsorção de azul de metileno

TABELA 5.6 Caracterização das amostras dos materiais inconsolidados que compõem a Unidade 03 quanto a sua localização, granulometria e índices físicos

TABELA 5.7 Caracterização das amostras dos materiais inconsolidados que compõem a Unidade 03 pelo método de adsorção de azul de metileno

TABELA 5.8 Caracterização da amostra dos materiais inconsolidados que compõem a Unidade 05 quanto a sua localização, 
granulometria e índices físicos

TABELA 5.9 Caracterização da amostra dos materiais inconsolidados que compõem a Unidade 05 pelo método de adsorção de azul de metileno

TABELA 5.10 Caracterização da amostra dos materiais inconsolidados que compõem a Unidade 06 quanto a sua localização, granulometria e índices físicos

TABELA 5.11 Caracterização da amostra dos materiais inconsolidados que compõem a Unidade 06 pelo método de adsorção de azul de metileno

TABELA 5.12 Caracterização da amostra dos materiais inconsolidados que compõem a Unidade 07 quanto a sua localização, granulometria e índices físicos

TABELA 5.13 Caracterização da amostra dos materiais inconsolidados que compõem a Unidade 07 pelo método de adsorção de azul de metileno

TABELA 5.14 Caracterização da amostra dos materiais inconsolidados que compõem a Unidade 08 quanto a sua localização, granulometria e índices físicos.

TABELA 5.15 Caracterização da amostra dos materiais inconsolidados que compõem a Unidade 08 pelo método de adsorção de azul de metileno.

TABELA 5.16 Caracterização das amostras dos materiais inconsolidados que compõem a Unidade 09 quanto a sua localização, granulometria e índices físicos.

TABELA 5.17 Caracterização das amostras dos materiais inconsolidados que compõem a Unidade 09 pelo método de adsorção de azul de metileno

TABELA 5.18 Caracterização das amostras dos materiais inconsolidados que compõem a Unidade 10 quanto a sua localização, granulometria e índices físicos

TABELA 5.19 Caracterização das amostras dos materiais inconsolidados 
que compõem a Unidade 10 pelo método de adsorção de azul de metileno.

TABELA 5.20 Caracterização da amostra dos materiais inconsolidados que compõem a Unidade 11 quanto a sua localização, granulometria e índices físicos.

TABELA 5.21 Caracterização da amostra dos materiais inconsolidados que compõem a Unidade 11 pelo método de adsorção de azul de metileno.

TABELA 5.22 Caracterização das amostras dos materiais inconsolidados que compõem a Unidade 13 quanto a sua localização, granulometria e índices físicos.

TABELA 5.23 Caracterização das amostras dos materiais inconsolidados que compõem a Unidade 13 quanto a sua localização, granulometria e índices físicos.

TABELA 5.24 Caracterização das amostras dos materiais inconsolidados que compõem a Unidade 15 quanto a sua localização, granulometria e índices físicos

TABELA 5.25 Caracterização das amostras dos materiais inconsolidados que compõem a Unidade 15 pelo método de adsorção de azul de metileno

TABELA 5.26 Caracterização das amostras dos materiais inconsolidados que compõem a Unidade 16 quanto a sua localização, granulometria e índices físicos.

TABELA 5.27 Caracterização das amostras dos materiais inconsolidados que compõem a Unidade 16 pelo método de adsorção de azul de metileno.

TABELA 5.28 Caracterização da amostra dos materiais inconsolidados que compõem a Unidade 17 quanto a sua localização, granulometria e índices físicos

TABELA 5.29 Caracterização da amostra dos materiais inconsolidados que compõem a Unidade 17 pelo método de adsorção de azul de metileno. 
TABELA 5.30 Caracterização das amostras dos materiais inconsolidados que compõem a Unidade 18 quanto a sua localização, granulometria e índices físicos........................................................

TABELA 5.31 Caracterização das amostras dos materiais inconsolidados que compõem a Unidade 18 pelo método de adsorção de azul de metileno

TABELA 5.32 Caracterização das amostras dos materiais inconsolidados que compõem a Unidade 19 quanto a sua localização, granulometria e índices físicos.

TABELA 5.33 Caracterização das amostras dos materiais inconsolidados que compõem a Unidade 19 pelo método de adsorção de azul de metileno

TABELA 5.34 Caracterização das amostras dos materiais inconsolidados que compõem a Unidade 20 quanto a sua localização, granulometria e índices físicos.

TABELA 5.35 Caracterização das amostras dos materiais inconsolidados que compõem a Unidade 20 pelo método de adsorção de azul de metileno.

TABELA 5.36 Caracterização da amostra dos materiais inconsolidados que compõem a Unidade 21 quanto a sua localização, granulometria e índices físicos

TABELA 5.37 Caracterização da amostra dos materiais inconsolidados que compõem a Unidade 21 pelo método de adsorção de azul de metileno

TABELA 5.38 Níveis hierárquicos propostos por Lollo (1996) para técnica de avaliação de terreno.

TABELA 5.39 Critérios Utilizados na Descrição das Unidades te Terreno....

TABELA 5.40 Comparação entre os resultados obtidos na composição dos Sistemas de Terreno por meio da Técnica de Avaliação de Terreno de Lollo (1996) em relação aos definidos pela análise de agrupamentos, para isso, considerando as condições de contorno estabelecidas para área em estudo. 
TABELA 5.41 Valores de exatidão global e coeficiente kappa obtidos para imagem da área estudada a partir dos algoritmos de classificação supervisionada fornecidos pelo $E N V I$ ® 3.2 ........ 117

TABELA 5.42 Resultados da distribuição das classes para o Mapa de Uso e Ocupação.

TABELA 5.43 Combinação de atributos e níveis que definem as classes da carta de potencial agrícola (Fonte: Zuquette, 1993).

TABELA 5.44 Classificação dos planos de informações obtidos por meio do mapa de materiais inconsolidados de acordo com suas classes de adequabilidade de potencial agrícola (de acordo com Zuquette, 1993)

TABELA 5.45 Resultados da distribuição das classes que compõem a Carta de Potencial Agrícola.

TABELA 6.1 Unidades geoambientais e sua(s) unidade(s) de terreno correspondente(s)

TABELA 6.2 Relação entre os setores destinados a pecuária bovina extensiva e as diversas classes/unidades presentes nas cartas de declividades e potencial agrícola e nos mapas de substrato rochoso e materiais inconsolidados

TABELA 6.3 Relação entre os setores destinados a monocultura cafeeira e as diversas classes/unidades presentes nas cartas de declividades e potencial agrícola e nos mapas de substrato rochoso e materiais inconsolidados

TABELA 6.4 Relação entre os setores de floresta nativa e as diversas classes/unidades presentes nas cartas de declividades e potencial agrícola e nos mapas de substrato rochoso e materiais inconsolidados

TABELA 6.5 Relação entre os setores sem cobertura vegetal e as diversas classes/unidades presentes nas cartas de declividades e potencial agrícola e nos mapas de substrato rochoso e materiais inconsolidados

TABELA 6.6 Relação entre os setores destinados as áreas urbanizadas e as 
diversas classes/unidades presentes nas cartas de declividades e potencial agrícola e nos mapas de substrato rochoso e materiais inconsolidados.............................................. 155

TABELA 6.7 Matriz de correlação obtida por regressão linear entre o percentual de superfície que cada unidade de uso e ocupação possui para as diferentes unidades geoambientais. 


\section{LISTA DE ABREVIATURAS E SIGLAS}

CPRM - Companhia de Pesquisa de Recursos Minerais

CTC - Capacidade de Troca Catiônica

FAB - Força Aérea Brasileira

IBGE - Instituto Brasileiro de Geografia e Estatística

IG - Instituto Geológico

IPT - Instituto de Pesquisas Tecnológicas do Estado de São Paulo S.A.

MCT - Miniatura, Compactado, Tropical

MDT - Modelo Digital de Terreno

MNT - Modelo Numérico de Terreno

PVC - Policloreto de Vinila

RMS - Erro Médio Quadrático

SE - Superfície Específica

SIG - Sistemas de Informação Geográfica

SUS - Sistema Único de Saúde

USAF - United States Air Force

UTM - Universal Transverse Mercator 


\title{
LISTA DE SÍMBOLOS
}

\author{
$\rho_{d}-$ Massa Específica Seca \\ $\rho_{\mathrm{s}}$ - Massa Específica dos Sólidos \\ Acb - Valor de Adsorção de Azul de Metileno para a Fração Argila dos Solos \\ e - Índices de vazios \\ n - Porosidade \\ $S_{r}$ - Grau de Saturação \\ Vb - Valor de Adsorção de Azul de Metileno para os Solos
}




\title{
RESUMO
}

\begin{abstract}
AMORIM, Holden Robson de. Estudo dos atributos do meio físico como base para o zoneamento geoambiental da região de influência do reservatório da Usina Hidroelétrica de Caconde (SP), escala: 1:50.000, com uso de geoprocessamento. 2003. 170 p. Dissertação Mestrado - Escola de Engenharia de São Carlos, Universidade de São Paulo, São Carlos.
\end{abstract}

Estudos geoambientais se propõem a avaliar e planejar o uso do solo tomando como base os principais atributos do meio físico. O objetivo principal desse trabalho é apresentar e aplicar uma proposta metodológica, considerando os procedimentos e os produtos da cartografia geotécnica desenvolvida para as condições brasileiras, que vise o planejamento territorial. A proposta foi aplicada na região de influência do reservatório da Usina Hidroelétrica de Caconde (SP). Foram avaliadas características geomorfológicas, geológicas, de solos (comportamento geotécnico) e aptidão agrícola. A carta de zoneamento geoambiental foi produzida por meio de trabalhos de geoprocessamento e análise de agrupamentos dos diversos planos de informações produzidos. Os resultados mostraram que a proposta funcionou adequadamente considerando os atributos do meio físico selecionados. Todos os produtos cartográficos gerados na pesquisa, encontram-se inseridos nos sistemas de informações geográficas Idrisi 32 e ArcView GIS 3.1, no qual este último associa aos mapas e cartas confeccionados um banco de dados geoambiental de modo a possibilitar que as informações possam ser acrescidas, inseridas, recuperadas, atualizadas ou simplesmente removidas desde que se queira ou se faça necessário.

Palavra-chave: Atributos do Meio Físico, Zoneamento Geoambiental, Geoprocessamento, Análise de Agrupamentos, Reservatório da Hidroelétrica de Caconde (SP). 


\title{
SUMMARY / ABSTRACT
}

\begin{abstract}
AMORIM, Holden Robson de. Study of the geoenvironment attributes as a subsidy to the geoenvironmental zoning in the region of influence at Caconde's Hydroelectric Reservoir (SP), scale: 1:50.000, using geoprocessing. 2003. 170 p. Dissertação Mestrado - Escola de Engenharia de São Carlos, Universidade de São Paulo, São Carlos.
\end{abstract}

Geonvironmental studies are important to promote environment management. The main objective of this work is to present and to apply a methodological proposal based in both procedures and products of the Engineering Geological Mapping that should aid the territorial planning. The proposal has been applied in the region of influence of the Caconde's Hydroelectric Reservoir (SP). Geological and geomorpholocial information were evaluated and the characteristics of unconsolidated materials and agricultural potential have been determined. Geoenvironmental zoning map was produced by using geoprocessing and cluster analysis techniques of several produced information plans. The proposal operate adequately environment attributes selected and realize appropriately the results. All cartographic products generated in this work were handled in the geographical information system Idrisi 32 and ArcView 3,1. Geoenvironmental database has been associated with produced maps in ArcView Gis.

Key-words: Geoenvironment Attributes, Geoenvironmental Zoning, Geoprocessing, Cluster Analysis, Caconde's Hydroelectric Reservoir (SP). 


\section{CAPÍTULO 1 - INTRODUÇÃO}

As transformações sociais, políticas e econômicas ocorridas no mundo desde a revolução industrial produziram significativas modificações na Terra. O homem, motivado principalmente pela utilização dos recursos naturais, intensificou e diversificou as formas de uso e ocupação do meio físico, quase sempre sem levar em consideração o conceito de desenvolvimento sustentável.

Segundo Diniz et al. (1999) a cartografia geotécnica subsidia o estudo de problemas do meio físico, especificamente, na análise de riscos e nas avaliações ambientais regionais. Os autores construíram, a partir da automação da cartografia geotécnica (passagem das informações cartográficas do meio analógico para o digital), uma Base de Dados Geoambientais para Estado de São Paulo. Esta, por sua vez, trouxe enormes benefícios podendo se transformar num poderoso instrumento que venha a comandar ações de planejamento e uso do solo, tais como: seleção de áreas para implantação de empreendimentos industriais ou residenciais, planos diretores, planos de defesa civil, estudos de impacto ambiental, planejamento e fiscalização de obras, elaboração de cartas de riscos, suscetibilidades e aptidões, seleção de áreas para disposição de resíduos sólidos, dentre outros. 
A área em estudo localiza-se no que corresponde à superfície formada pela bacia de contribuição da Usina Hidroelétrica de Caconde (SP). Embora a área esteja situada numa das regiões com maior potencial agrícola e pecuário do país, esta ainda carece de estudos que levem em consideração zoneamentos geotécnicos e geoambientais em escalas consideradas regionais. Tais avaliações são de extrema necessidade na atualidade, tendo em vista que o uso e a ocupação inadequada do meio físico pode tornar os recursos naturais exauríveis, principalmente o recurso hídrico, tão presente e fundamental no desenvolvimento econômico e social da região.

\subsection{Objetivos}

Em linhas gerais, o presente trabalho busca o zoneamento geoambiental da área em estudo através da construção da carta geoambiental totalmente integrada a sistemas de informações geográficas (ArcView GIS 3.1 e Idrisi 32), para isso, considera os procedimentos e os produtos da cartografia geotécnica proposta por Zuquette (1987), Zuquette \& Gandolfi (1990), Zuquette (1993) e Zuquette et al. (1997).

Desse modo, pretende-se confeccionar e apresentar um conjunto de produtos cartográficos geotécnicos que forneçam as bases para o estabelecimento de um zoneamento geoambiental fundamentado nas informações do meio físico.

Este trabalho objetiva, ainda, estudar a viabilidade da utilização da técnica de estatística multivariada, denominada de análise de agrupamentos associada ao geoprocessamento na definição das unidades geoambientais. 


\section{CAPÍTULO 2 - REVISÃO BIBLIOGRÁFICA}

\subsection{Bacias Hidrográficas}

\subsubsection{Definição, Tipos e Padrões de Drenagem}

Segundo Guerra (1980) uma bacia hidrográfica pode ser definida como um conjunto de terras drenadas por um rio principal e seus afluentes (Figura. 2.1). A quantidade de água que atinge os cursos fluviais é dependente do tamanho da área ocupada pela bacia, da precipitação total e de seu regime, além das perdas devidas à evapotranspiração e à infiltração.

Christofoletti (1974) classifica as bacias de drenagem, de acordo com escoamento global, nos seguintes tipos:

a) Exorreicas, quando o escoamento das águas se faz de modo contínuo até o mar ou oceano;

b) Endorreicas, quando as drenagens são internas e não possuem escoamento até o mar, desembocando em lagos ou dissipando-se nas areias do deserto, ou perdendo-se nas depressões cársticas;

c) Arreicas, quando não existe nenhuma estruturação em bacias hidrográficas, como nas áreas desérticas onde a precipitação é negligenciável e a atividade dunária é intensa, obscurecendo as linhas e os padrões de drenagem;

d) Criptorreicas, quando as bacias são subterrâneas, como em áreas cársticas. A drenagem subterrânea acaba por surgir em fontes ou integrar-se em rios subaéreos. 


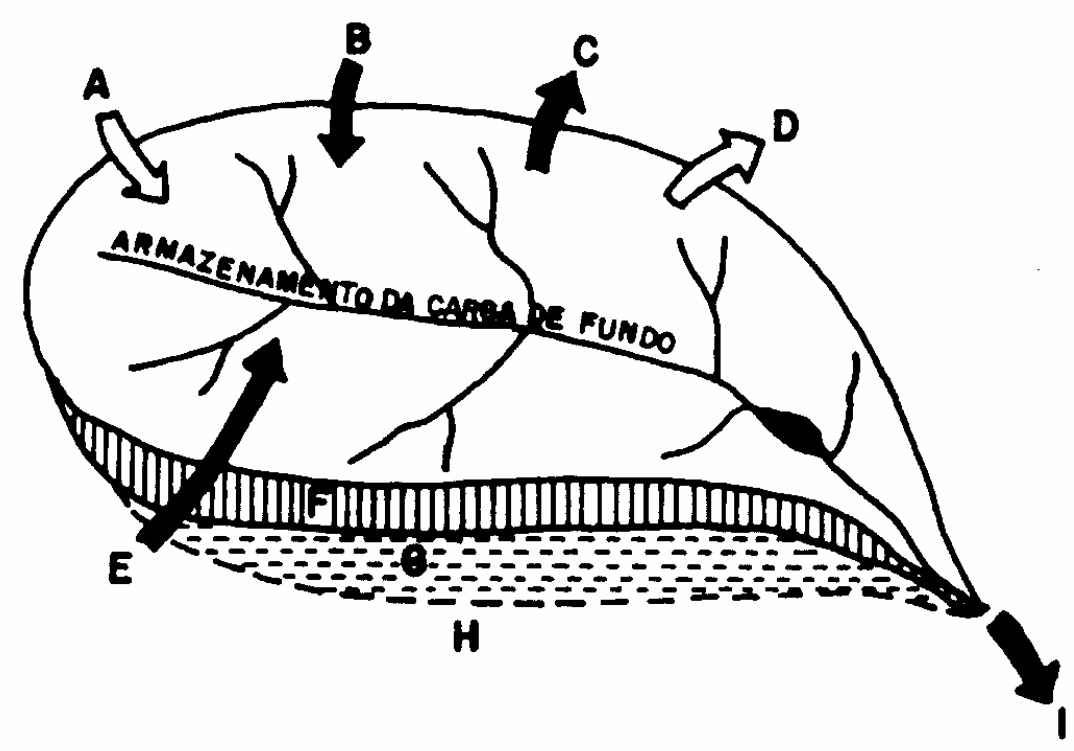

FIGURA 2.1 - Bacia hidrográfica, fluxos e transformações de energia, água e sedimentos. (A) energia radiante, (B) precipitação, (C) evapotranspiração, (D) energia latente, (E) material intemperizado, (F) armazenamento de umidade de solo, (G) armazenamento de água subterrânea, (H) material fonte, (I) descarga, transporte de sedimentos em suspensão, dissolvidos e de fundo. (Fonte: Cunha \& Guerra, 1996).

No estudo de bacias hidrográficas é muito importante a caracterização dos padrões de drenagens (Figura 2.2), estes definidos como o arranjo espacial dos cursos fluviais, que podem ser influenciados em sua atividade morfométrica pelo tipo e disposição das camadas rochosas, pela resistência litológica variável, pelas diferenças de declividade e pela evolução geomorfológica da região. Uma ou várias bacias podem estar englobadas na caracterização de um determinado padrão. 


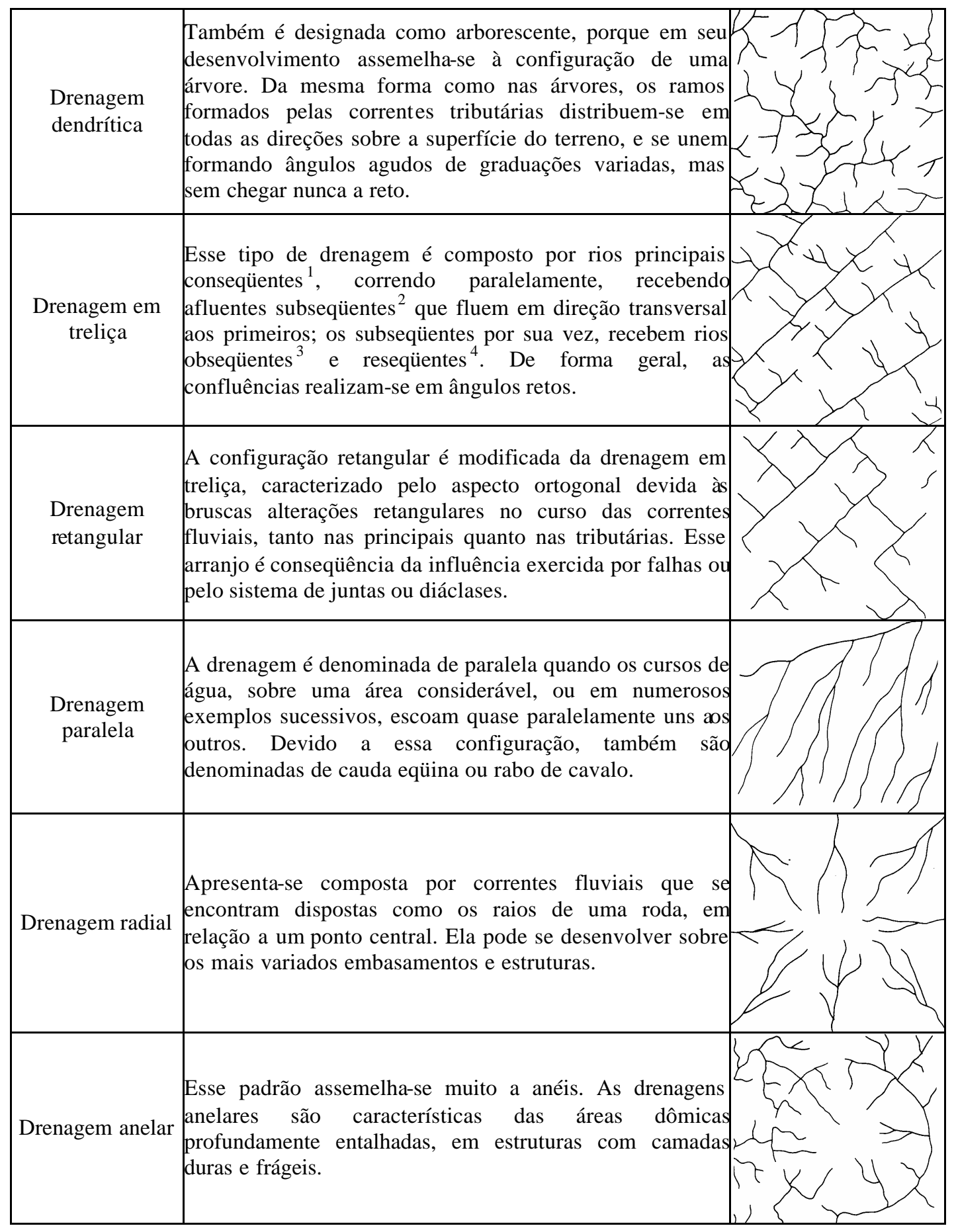

FIGURA 2.2 - Disposição espacial dos principais tipos de padrão de drenagem (Fonte: Christofoletti, 1974).

\footnotetext{
${ }^{1}$ Rios cujos cursos foram determinados pela declividade da superfície terrestre, em geral coincidino com a direção da inclinação principal das camadas.

${ }^{2}$ Rios cuja a direção de fluxo é controlada pela estrut ura rochosa, acompanhando sempre uma zona de fraqueza, tal como uma falha, junta, camada rochosa delgada ou facilmente erodível.

${ }^{3}$ Rios que correm em sentido inverso à inclinação das camadas ou a inclinação original dos rios consequentes.

${ }^{4}$ Rios que correm na mesma direção dos rios consequentes, mas nascem num nível mais abaixo.
} 


\subsubsection{A Bacia Hidrográfica como Limite Territorial para o Planejamento e Gerenciamento Ambiental}

Segundo Chaudhry (2000) os recursos hídricos são os recursos naturais mais importantes e devem ser geridos de forma integrada tendo em vista a importância da água em relação aos seus usos diversos (abastecimento urbano e industrial; irrigação; geração de energia elétrica; recreação e turismo ecológico; navegação fluvial; etc), a manutenção de qualidade e quantidade e o aproveitamento otimizado com o mínimo de conflitos. Essa postura de gerenciamento integrado se torna, nos dias de hoje, mais necessária ao se constatar que os recursos hídricos são limitados e que podem sofrer sérios danos como resultado de uma exploração desordenada (Figura 2.3).

De acordo com Pires \& Santos (1995) as abordagens do planejamento do uso do solo baseada em critérios econômicos clássicos tem falhado por não reconhecer o conflito entre as metas de desenvolvimento econômico e a capacidade de suporte dos ecossistemas. Somente uma abordagem holística, que verifique causas e efeitos das intervenções humanas e interprete as condições ambientais de toda a área estudada, permitirá traçar diretrizes de desenvolvimento adequadas ao ambiente físico e biológico.

Segundo Pires Neto (1994) as bacias hidrográficas são as unidades de gerenciamento ambiental mais adequadas dentro de um planejamento territorial, sendo perfeitamente possível caracterizá-las quanto às restrições e potencialidades ao uso urbano, a exploração dos recursos minerais e de águas subterrâneas, como também as potencialidades, restrições e impactos associados ao uso agropecuário e extrativista do terreno.

Para Prochnow (1990) a adoção da bacia hidrográfica como unidade de planejamento ambiental se justifica não só por esta se constituir em uma unidade física bem caracterizada, mas também porque não existe nenhuma região continental, por menor que seja, que não se integre a uma bacia. 


\section{Urbanização - Industrialização Agricultura - Mineração}

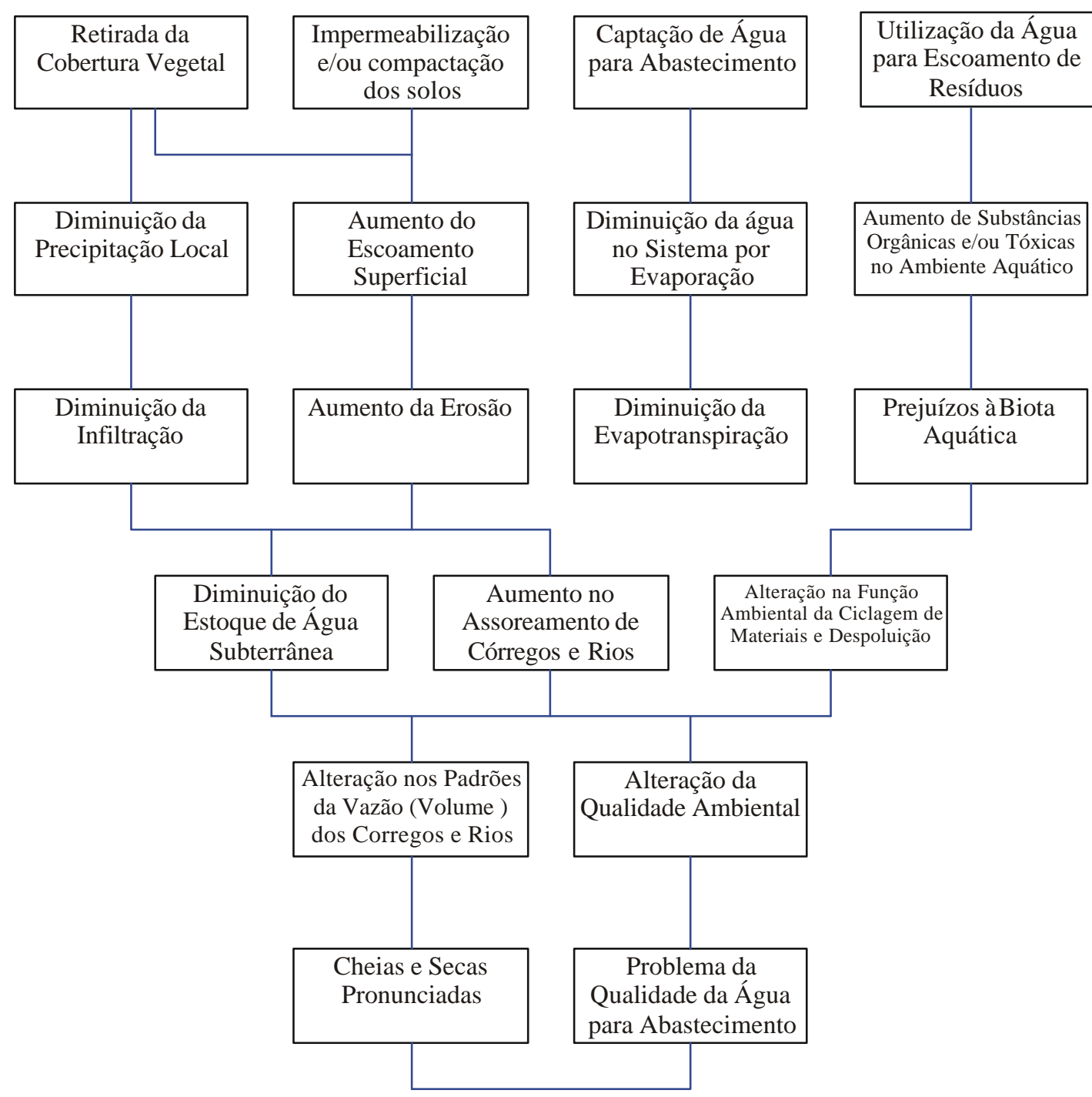

FIGURA 2.3 - Principais usos do solo e possíveis interferências nos recursos hídricos (Fonte: Pires \& Santos, 1995). 
Para Pires \& Santos (1995), a bacia de drenagem funciona como unidade de planejamento e gerenciamento, pois ntegra os aspectos ambientais, econômicos e políticos, com ênfase no primeiro, isso porque a capacidade de dar suporte ao desenvolvimento possui sempre um limite, a partir do qual todos os outros aspectos serão inevitavelmente afetados. Entretanto, no inicio o gerenciamento e planejamento de bacias hidrográficas somente se limitava a questão do problema hídrico em si, ou seja, controle de inundações, irrigação, navegação e abastecimento público e industrial. Posteriormente, com o aumento excessivo da demanda, os técnicos amadurecidos na administração tiveram a necessidade de incorporar aspectos relacionados aos vários usos de água para atender os múltiplos usuários, que muitas vezes competiam pelo recurso. A partir desse novo cenário, ao se buscar solucionar o conflito entre os usuários, é que surgiu a necessidade de dimensionar a qualidade e quantidade do recurso para cada um, bem como sua responsabilidade. Para o gerenciamento ambiental de bacias hidrográficas os autores destacam as seguintes etapas:

a) Etapa de diagnóstico ambiental - o objetivo dessa etapa é analisar a situação atual do uso do solo, o nível de aproveitamento dos recursos naturais através de: inventário e levantamento dos dados e informações sobre o ambiente físico e biológico; levantamento das áreas ambientais críticas; análise das informações e classificação das unidades geográficas de acordo com a capacidade de absorver os diversos usos humanos, considerando suas restrições ambientais.

b) Prognóstico ambiental - nessa etapa são analisadas prováveis condições futuras (inclusive as insustentáveis) em diferentes cenários de tempo e ocupação do espaço, frente as tendências de desenvolvimento e a demanda de serviços e produtos.

c) Integração das análises ambientais, políticas e econômicas do plano de gerenciamento de bacias hidrográficas. 
Lanna (1995) destaca como aspecto vantajoso de se adotar a bacia hidrográfica como unidade territorial de planejamento e gerenciamento ambiental, o fato que a rede de drenagem de uma bacia pode ser capaz de indicar as relações de causa e efeito de problemas ambientais, por outro lado, muitas vezes os limites municipais e estaduais não acompanham os divisores da bacia, o que pode acarretar problemas no seu gerenciamento em função de questões políticas.

Ross \& Del Prette (1998) apontam que no Brasil a gestão ambiental caminha progressivamente no sentido de tomar as bacias hidrográficas como unidades de planejamento regional, com clara ênfase na questão dos recursos hídricos, seguindo o modelo francês de gerenciamento de Bacias Hidrográficas. Os autores indicam a necessidade de adoção de uma política que contemple todas as áreas dos recursos naturais (águas, solos, relevo, atmosfera, subsolo, flora, fauna) e as componentes sociais e econômicas, não apenas em termos de bacias hidrográficas, mas também considerando sua inserção regional e sua articulação com os problemas nacionais.

\subsection{Estudos Geoambientais}

\subsubsection{Motivações}

O homem chega ao século XXI com a população superando seis bilhões de habitantes e com um crescimento populacional superior a 100 milhões de pessoas por ano. Por conta desse enorme crescimento, observa-se uma grande transformação no planeta.

O homem altera substancialmente o globo quase sempre sem levar em consideração o risco que traz a sua própria sobrevivência como as dos outros componentes da biosfera através da poluição do ar, do desmatamento intensivo, do acúmulo de produtos e resíduos tóxicos e do uso intensivo das últimas jazidas de reserva fóssil. 
De acordo com Cunha \& Guerra (1996) a mundialização da questão ambiental teve inicio na $1^{\text {a }}$. Conferência das Nações Unidas sobre o Meio Ambiente realizada em junho de 1972, em Estocolmo, movida pela degradação ambiental em todo o mundo que se refletia em poluição industrial, exploração dos recursos naturais, deterioração das condições ambientais e problemas sanitários.

A reunião de 1992 no Rio de Janeiro, levou a discussão sobre o desenvolvimento sustentado e a necessidade de alterações profundas que levassem em conta a capacidade de suporte do planeta, fluxo de energia e a complexidade dos ecossistemas, com ênfase na interdependência dos fatores (Tundisi, 2000).

\subsubsection{Desenvolvimento Sustentado e Gestão Ambiental}

O desenvolvimento sustentado é a exploração dos recursos naturais feito de forma que as gerações futuras possam utilizar esses recursos e beneficiar-se de um processo contínuo e equilibrado, no qual a redução das desigualdades econômicas e a diminuição da pobreza sejam metas fundamentais. Outros aspectos devem ser levados em consideração como: a preservação e a restauração dos ecossistemas naturais, a reciclagem de materiais e o deslocamento das prioridades de um crescimento quantitativo para um crescimento qualitativo (Tundisi, 2000).

Segundo o autor para a compreensão da complexidade que envolve o problema ambiental é necessário o desenvolvimento de técnicas e metodologias adequadas que possibilitem um melhor conhecimento dos ecossistemas, suas funções, características e balanço energético, considerando-se problemas biogeofísicos, econômicos e sociais.

Nesse contexto, insere-se o conceito de instrumentos de gestão ambiental definidos por Bitar \& Ortega (1998) como sistematização de procedimentos técnicos e administrativos para assegurar a melhoria e o aprimoramento contínuo do desempenho ambiental de um empreendimento ou de uma área a ser protegida e, em decorrência, obter o reconhecimento de conformidade das medidas e práticas adotadas. 
De acordo com Bitar \& Ortega (1998), no Brasil, alguns desses instrumentos têm sido objetos de legislação e normalização técnica, podendo ser subdivididos em dois grupos segundo a escala territorial (Tabela 2.1).

Gothe (1991) afirma que o Estado brasileiro é ineficiente ao tratar da questão ambiental, realizando ações esporádicas e pontuais, atuando principalmente a reboque da manifestação da sociedade civil, minimizando os impactos negativos de empreendimentos isolados por pressão de grupos organizados. Desse modo, mostrando a falta de consciência de que o meio ambiente permeia todos esse setores e que na verdade, a gestão ambiental está imbricada com boa parte das atividades do estado, não podendo, portanto, ser comprimida a um pequeno setor da administração pública, também estanque em relação aos demais. O autor propõe uma série de medidas para evitar a permanência do atual quadro caótico referentes à gestão ambiental, são elas:

a) Aglutinar de forma efetiva pessoas e instituições cujas atividades visem a proteção do meio ambiente ou sejam causa de significativas modificações ambientais - na administração pública, nas estatais, empresas e organizações não governamentais - efetivando e expandindo o conceito de sistema nacional de meio ambiente, resgatando-o da letra da lei para a prática diária. A participação de todos os setores envolvidos proporciona uma troca e homogeneização de informações, um conhecimento mútuo das necessidades, condicionantes e metas que, mesmo não conduzindo ao consenso, contribui para aprimorar a base técnica e o jogo democrático das discussões envolvendo a questão ambiental; 
TABELA 2.1 - Instrumentos de gestão ambiental (Fonte: Bitar \& Ortega, 1998).

\begin{tabular}{|c|c|}
\hline \multicolumn{2}{|c|}{ GESTÃO AMBIENTAL } \\
\hline \multirow{8}{*}{$\begin{array}{l}\text { Instrumentos de gestão ambiental de } \\
\text { empreendimentos ou gerenciamento ambiental }\end{array}$} & Avaliação de impacto ambiental \\
\hline & Recuperação de áreas degradadas \\
\hline & Monitoramento Ambiental \\
\hline & Análise de riscos ambientais \\
\hline & Investigação de passivo \\
\hline & ambiental \\
\hline & Seguro ambiental \\
\hline & Sistema de gestão ambiental \\
\hline \multirow{4}{*}{$\begin{array}{l}\text { Instrumentos de gestão ambiental de áreas } \\
\text { geograficamente delimitadas }\end{array}$} & Bacias hidrográficas \\
\hline & $\begin{array}{c}\text { Unidades de conservação } \\
\text { ambiental }\end{array}$ \\
\hline & Áreas costeiras \\
\hline & Áreas metropolitanas \\
\hline
\end{tabular}

b) Dar peso significativo ao meio ambiente na tomada de decisão e na formulação das várias políticas setoriais, fazendo com que o estado incorpore a temática e a legislação ambiental, num prazo máximo de cinco anos. Isso envolve basicamente reformular e reestruturar a administração pública, despreparada e mal equipada, através de um programa de formação de competência técnica, científica e gerencial em gestão ambiental, para pessoal dos vários setores (energia, transporte, agricultura, mineração, etc) além dos órgãos ambientais. Ênfase especial deve ser dada ao trabalho multidisciplinar já que, embora não se discuta a existência de bons cientistas e técnicos no país, estes se encontram dispersos nas instituições, não trabalham sob uma ótica multidisciplinar e os especialistas não tem sequer uma linguagem comum para discussão; 
c) Dar atenção à formulação da opinião pública, no sentido também de capacitála a bem utilizar os recentes canais de participação popular;

d) Solucionar uma questão chave do gerenciamento ambiental, ainda mal equacionada no Brasil e nos países do Terceiro Mundo, relativo às relações comerciais que impõem a venda de matérias primas a custos irrisórios, promovendo uma verdadeira expropriação dos recursos naturais, e transferência de produtos e processos caros e altamente poluidores, muitas vezes proibidos nos países ricos. Um outro aspecto é que a péssima distribuição de renda nos países pobres promove a instalação de massas famintas, que se encontram privadas de terra para subsistência e moradia, em áreas altamente sensível a intervenção antrópica.

e) Rever o papel das organizações ambientalistas não governamentais, independentes dos seus objetivos e estratégias com objetivo de evitar denúncias tecnicamente infundadas.

Segundo Ross \& Del Prette (1998) a gestão ambiental, em âmbito nacional, carece de um conjunto de áreas integradas que faça parte de uma política mais ampla, dentro de um plano estratégico de desenvolvimento. Existe uma grande necessidade de implementação de um amplo projeto de desenvolvimento sustentável, com objetivos claros de um desenvolvimento econômico para a melhoria progressiva das condições sociais e a adoção de políticas de preservação, de conservação e recuperação ambiental, indicando como um dos primeiros passos a implementação de zoneamentos ecológico-econômicos nos estados. 


\subsubsection{Geoambiente e a Ação Antrópica}

Ambiente é tudo que nos cerca. Nós vivemos numa interface dinâmica entre atmosfera, hidrosfera e litosfera. Os seres humanos são formados a partir dessa interface, sendo afetados por ela sempre numa escala crescente. O termo ambiente geológico ou simplesmente geoambiente se refere à parte mais superior da litosfera que é significativamente afetada pelas atividades humanas (Figura 2.4). O geoambiente é composto por rochas, solos, fluidos, gases e organismos sendo conectado e influenciado pela atmosfera, clima, condições geológicas do terreno e cobertura vegetal. As atividades humanas interagem com os processos geológicos, físicos químicos e bioquímicos que ocorrem nos solos e rochas (Aswathanarayana, 1995).

De acordo com o autor os impactos provocados pelo homem atingem:

a) Rochas - com a mudança na composição, estrutura e propriedades geológicas das rochas e no manto de intemperismo;

b) Solos - com a criação de novos solos primários, e, modificação nos processos de formação do solo, que afetam o manto rochoso e o regime de água subterrânea;

c) Água superficial e subterrânea - estes são sem dúvida os mais dinâmicos componentes do geoambiente, e os mais afetados pelas atividades do homem. Proteção das águas superficiais e subterrâneas e diminuição da poluição constituem as tarefas mais importantes realizadas pela comunidade;

d) Microorganismos - afetando os processos hidroquímicos e a qualidade da água.

e) Atmosfera - através da poluição atmosférica podendo penetrar na hidrosfera, biosfera e litosfera, com o risco causar mudanças indesejáveis no clima, solos, vegetação e qualidade da água. 


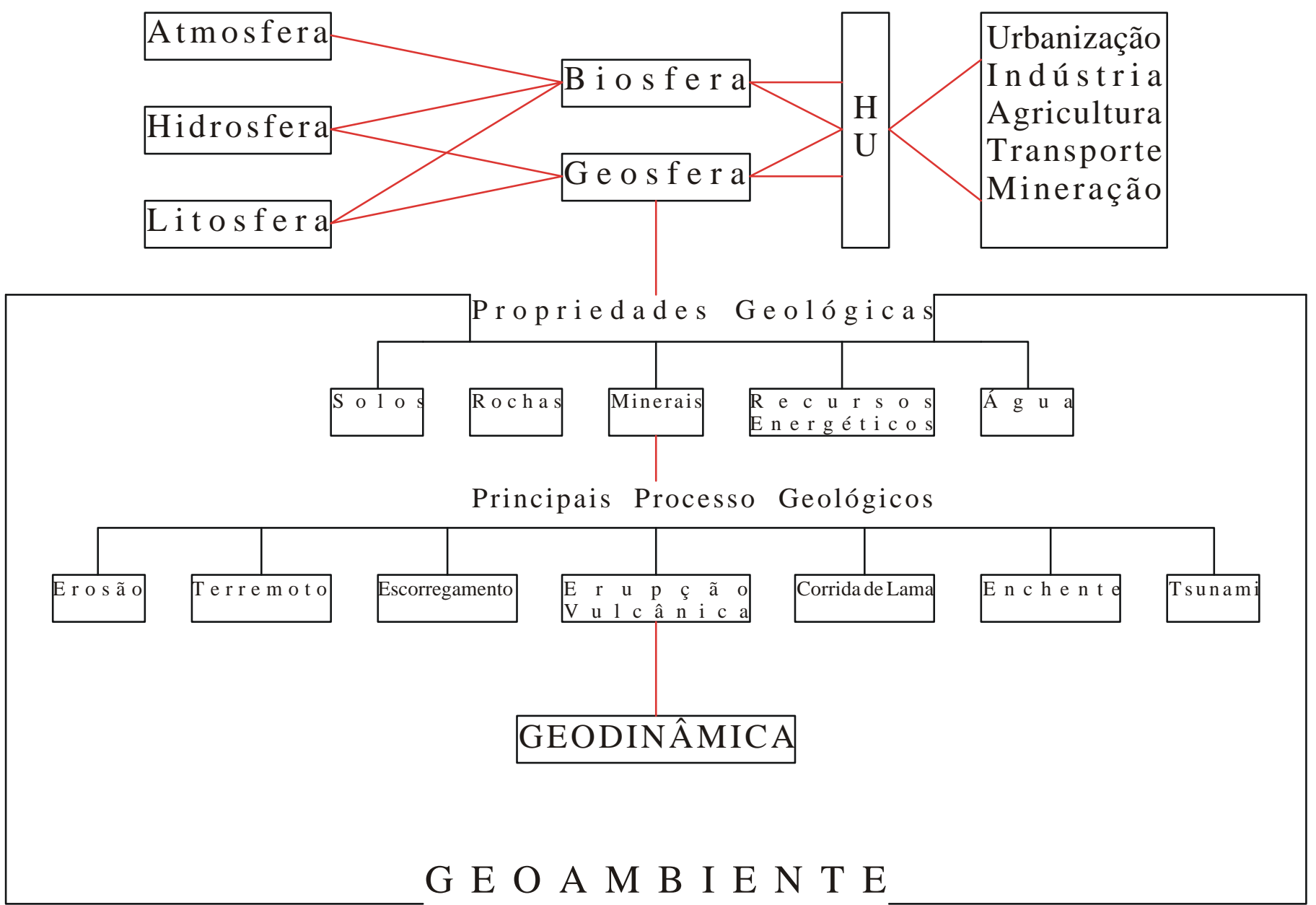

FIGURA 2.4 - Representação esquemática das relações e interações no geoambiente (Modificado de Aswathanarayana, 1995). 
De acordo com Aswathanarayana (1995) as principais atividades que geram impactos na dinâmica do geoambiente são:

a) Mineração - mudança na paisagem, escorregamentos, subsidência, poluição da água e solo, diminuição do nível freático, perigo causado por explosões;

b) Obras Civis - escorregamentos, corridas de lama, queda de blocos, inundação, subsidência, mudança no nível freático.

c) Industrias - poluição da água, solo, ar e biota.

d) Agricultura e silvicultura - erosão, escorregamentos, salinização do solo, poluição da água, inundação.

e) Turismo - poluição da água e do solo

f) Disposição de lixo - poluição da água e do solo, agressão as rochas sobrejacentes, efeitos termais.

Segundo Ross (1996) os estudos de impactos ambientais (EIA) são obrigatórios pela legislação brasileira, para qualquer grande investimento que demande a execução de obras de engenharia. Os estudos de impactos ambientais e os respectivos relatórios de impacto ambiental (RIMA) são parte dos instrumentos da política nacional de meio ambiente, conforme se destacam na lei 6938 de 31 de agosto de 1981.

\subsubsection{Exemplos de Metodologias Desenvolvidas em Estudos Geoambientais}

\section{METODOLOGIAS ESTRANGEIRAS}

\section{Metodologia Empregada por Cendrero (1975)}

Cendrero (1975) realizou na baía de Santander norte da Espanha um mapeamento geológico-ambiental baseado na metodologia e conceitos empregados pelo Departamento de Geologia Econômica do Texas, em Austin. 
Inicialmente, são definidos sistemas tomando como base os ambientes geológicos (ambiente lagunar, fluvial, costeiro, etc) da área, em seguida para cada sistema suas respectivas unidades, estas baseadas em processos ativos, landforms, propriedades físicas dos materiais, assembléias biológicas e influência do homem.

Cendrero (1975) avalia a capacidade ambiental das unidades geológicoambientais utilizando 21 tipos de atividades humanas. O autor acha conveniente a distinção no mapa entre as atividades que são nocivas para o meio ambiente se executadas sobre determinadas unidades; ou se o efeito prejudicial se dá do meio sobre a atividade.

O produto final é a confecção de um mapa geológico-ambiental que pode ser utilizado no planejamento, principalmente na definição das unidades para disposição de lixo, preservação ambiental e áreas adequadas a construção.

É salientado que as unidades geológico-ambientais e de uso da terra e da água são freqüentemente dinâmicas e sujeitas a mudanças, sendo as informações representativas da situação da data que foram mapeadas.

\section{Metodologia Empregada por Cendrero et al. (1990)}

Cendrero et al. (1990) construíram mapas geocientíficos com fins planejamento para duas áreas, uma na Província de Valência e a outra na ilha de Gran Canarianas (Canaria).

A abordagem metodológica utilizada considera a identificação e integração de unidades de acordo com Cristian \& Stewart (1968) e Cendrero et al. (1986). Segundo os autores, o ambiente morfodinâmico é a maior unidade que pode ser delimitada para um mapa base geocientífico. Esse definido, tomando como base o clima, as feições morfoestruturais e topográficas. O ambiente morfodinâmico pode ser dividido em sistemas morfodinâmicos. Os sistemas são delimitados a partir de landforms, embasamento rochoso e depósitos superficiais. Por fim, os sistemas podem ainda ser sub-divididos em unidades morfodinâmicas, estas determinadas através da litologia, dos solos, da geomorfologia, dos processos ativos, da vegetação e da influência humana. 
As unidades morfodinâmicas são utilizadas nos processos de planejamento servindo como base para mapas derivados de risco geológico, capacidade de uso do solo, grau de erosão presente, potencial de erodibilidade e qualidade para conservação.

\section{Metodologia Empregada por Dai et al. (2001)}

Dai et al. (2001) propõem o zoneamento geoambiental como instrumento de planejamento do espaço urbano chinês, que tem uma das maiores taxas de crescimento populacional do mundo. A área de estudo selecionada localiza-se na cidade de Lanzhou, capital da Província de Gansu, a Segunda maior cidade a noroeste da China.

De acordo com os autores a avaliação do planejamento urbano requer o manuseio de uma grande quantidade de informações espaciais. Desse modo, propõem a utilização de sistemas de informação geográfica na integração de diversos planos de informação com o objetivo de se produzir cartas que auxiliem esse planejamento.

Baseado em aspectos topográficos, condições geológicas e hidrogeológicas e histórico de acidentes geológicos os autores conseguiram cruzar todos os atributos por eles considerados, seguindo o Processo Analítico Hierárquico. O resultado final mostrou a adequabilidade do meio físico considerando diversas categorias de uso urbano (Figura 2.5).

\section{Metodologia Empregada por De Villota et al. (2002)}

Os autores propõem o zoneamento geoambiental com a finalidade de orientar a ocupação urbana da região de Vall de Gallinera (Mediterrâneo Espanhol). De acordo com De Villota et al. (2002), o objetivo principal da metodologia é relacionar de forma clara e acessível parâmetros e problemas relacionados ao meio ambiente e a arquitetura, de modo que os profissionais de ambas as áreas possam desenvolver uma interação reciproca entre suas disciplinas. 


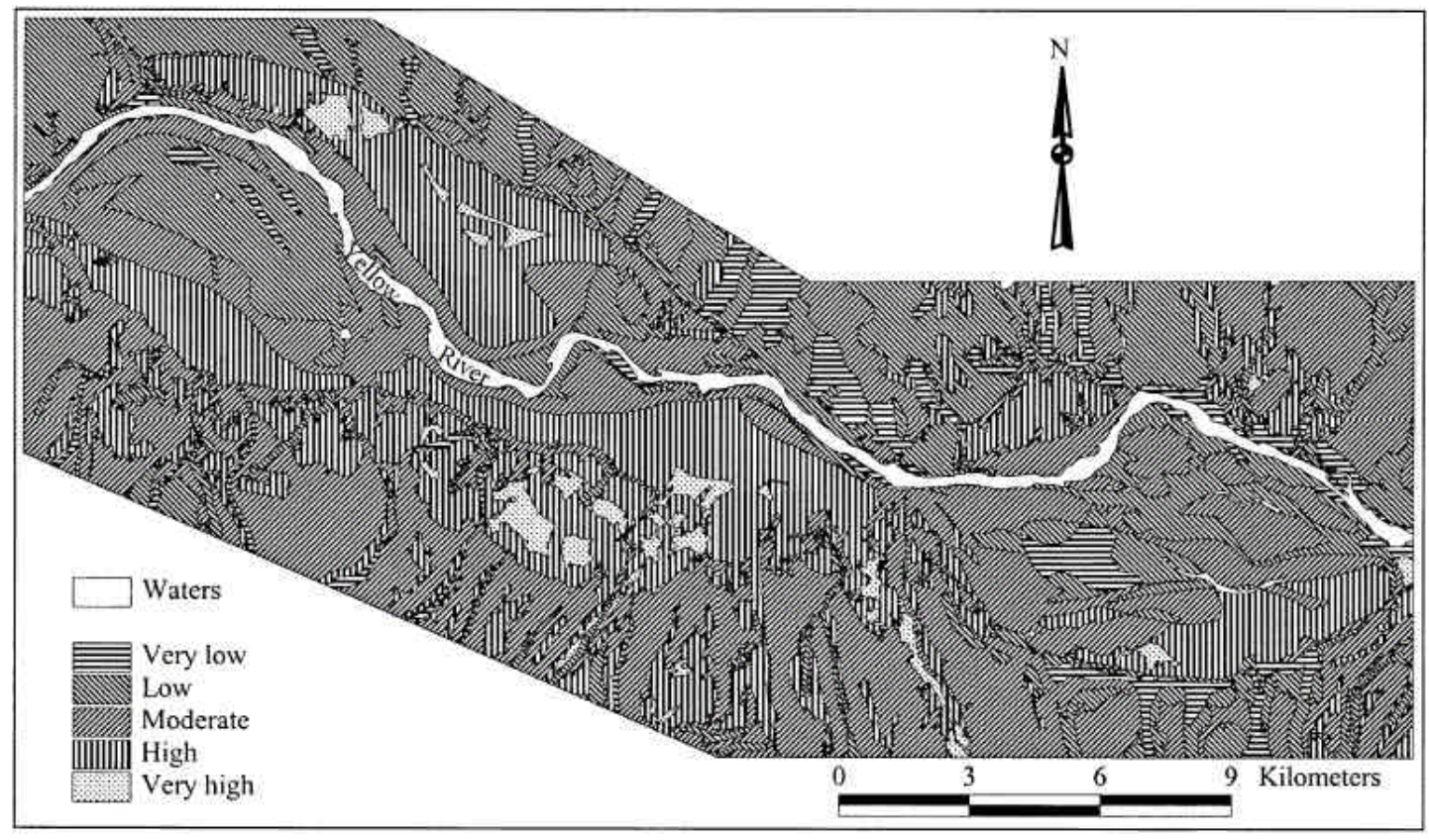

FIGURA 2.5 - Carta de aptidão a disposição de resíduos sólidos (Fonte: Dai et al., 2001).

A metodologia envolve basicamente três etapas. Na primeira ocorre a compilação de dados de ensaios realizados, publicações produzidas consideradas relevantes, mapas temáticos gerais, fotografias aéreas, análise de materiais e projetos envolvidos nas construções já existentes.

Nessa fase é produzido o mapa de recomendações e limitações quanto ao uso (mapa geoambiental) através da união entre o mapa de unidades homogêneas (constituídos pelos planos de informações de declividades, litologias, formas do terreno e domínios geomorfológicos), unidades ambientais (constituídos pelos planos de informações de hidrologia, solos, clima e vegetação) e unidades de paisagem (constituídos pelos planos de informações de qualidades, fragilidade e riscos do meio físico além das atividades humanas desenvolvidas).

A segunda fase envolve a análise e integração dos resultados obtidos na fase anterior de forma a determinar quais parâmetros-chave poderiam estar relacionados com a zona rural e suas interações com meio ambiente local. 
$\mathrm{Na}$ última etapa da metodologia é determinada a relação entre as características ambientais e de arquitetura, em todos os níveis, de modo a se determinar o grau de integração e compatibilidade entre a arquitetura e o meio ambiente.

\section{METODOLOGIAS NACIONAIS}

\section{Metodologia Empregada pelo IG (Vedovello et al., 1999)}

Vedovello et al. (1999) sugerem a utilização de geoprocessamento em cartografia geotécnica com a finalidade de gestão ambiental. Desse modo, a partir do emprego de sistemas de informação geográficas, associado aos produtos cartográficos geotécnicos produzidos, é construído um sistema gerenciador de informações geoambientais especialmente desenvolvido para a gestão de resíduos sólidos.

De acordo com os autores, uma das principais motivações para a construção do banco de dados geoambientais, foi a necessidade de armazenamento da grande quantidade de dados de natureza geológica-geotécnica colecionados pelo Instituto Geológico de São Paulo através de vários projetos de pesquisa realizados.

Vedovello et al. (1999) desenvolveram um sistema de banco de dados voltado a disposição de resíduos industriais e domésticos para a Região Metropolitana de Campinas a partir da análise das características geoambientais que interferem nas condições de segurança do empreendimento e na manutenção da qualidade geoambiental da região.

Os autores obtiveram um sistema de banco de dados geoambientais que além de apresentar as informações geológico-geotécnicas de natureza pontual (perfis geotécnicos, perfis geológicos, sondagens geotécnicas, poços tubulares profundos, atividades de mineração, fotografias aéreas, etc.) também disponibilizou sete produtos cartográficos necessários a gestão dos resíduos, são eles: Mapa de aspectos sócio-políticos; Mapa de compartimentação fisiográfica; Mapa geológico; Mapa de distribuição pluviométrica; Mapa de susceptibilidade a processos de erosão, escorregamentos e inundações; Mapa de vulnerabilidade a poluição dos aqüíferos e Mapa de avaliação regional para a disposição de resíduos. 


\section{Metodologia Empregada pela CPRM (Dantas, 2000)}

Dantas (2000) define zoneamento geoambiental como um diagnóstico físicobiológico, cujo objetivo maior é individualizar zonas homogêneas, com características similares, possibilitando orientar o planejamento do território.

O autor propõe a carta de zoneame nto geoambiental para o Estado do Rio de Janeiro a partir do emprego da abordagem geoecológica, na qual o ecótono, ou unidade geoambiental, é um produto singular da combinação de elementos geobiofísicos e geoeconômicos, que se transformam ao longo do tempo em resposta à dinâmica dos processos desencadeados no meio ambiente.

A proposta metodológica analisa diversos temas tais como: geologia, geomorfologia, pedologia, hidrologia, geotecnia, hidrogeologia, uso do solo, vegetação, clima, infra-estrutura dos serviços, aspectos socioeconômicos e fundiários, e capacidade de uso do solo para fins agrícolas. A metodologia que envolve a construção da carta geoambiental busca delimitar as unidades territoriais em função das combinações mútuas entre fatores do potencial geoecológico (condições geológicas, geomorfológicas, climáticas e hidrológicas \hidrogeológicas) e os fatores da exploração biológica, com ênfase para os solos e a vegetação.

\section{Metodologia Empregada pelo IPT (Diniz et al., 1999)}

A exemplo da metodologia desenvolvida pelo IG (Vedovello et al., 1999), o IPT (Diniz et al., 1999) considera para a construção de uma base de dados geoambientais para o Estado de São Paulo os produtos gerados a partir da automação da cartografia geológico-geotécnica.

A proposta metodológica possui quatro objetivos principais, são eles:

a) Apresentar a cartografia como ferramenta para o estudo de processos do meio físico e modelagem de bases de dados geoambientais;

b) Apresentar diretrizes para o desenvolvimento de base de dados geoambientais em SIG, visando aplicações, como: avaliação ambiental e análise de riscos geológico-geotécnicos; 
c) Propor uma modelagem de bases de dados geoambientais utilizando como estrutura suporte a automação da cartografia geotécnica visando sua aplicação em inventário cartográfico, SIG, multimídia e home page;

d) Elaborar a Base de Dados Geoambientais do Estado de São Paulo, através das etapas de modelagem lógica, modelagem física, planejamento cartográfico, digitalização georeferenciada, geocodificação e a discretizacão da Carta Geotécnica do Estado de São Paulo em layers (camadas).

O enfoque metodológico-cartográfico-geotécnico adotado pelo IPT abrange o contexto que valoriza a solução de problemas existentes ou possíveis, desse modo realiza:

a) pré-estabelecimento de um modelo espacial que integre o conjunto de problemas verificados e potenciais;

b) conhecimento das causas e condicionantes dos comportamentos e dos fenômenos;

c) investigação dirigida através das evidencias acessíveis (dados preexistentes, imagens de sensoriamento remoto, investigação de campo, sondagens e ensaios);

d) uso intenso de todo o universo de dados disponíveis.

De acordo com Diniz et al. (1999) o sistema georeferenciado se constitui em importante instrumento para subsidiar as ações de planejamento e uso do solo, tais como: seleção de áreas para implantação de empreendimentos industriais ou residenciais, planos diretores, planos de defesa civil, estudos de impacto ambiental, planejamento e fiscalização de obras, elaboração de cartas de riscos, susceptibilidades e aptidões, seleção de áreas para disposição de resíduos sólidos, dentre outros.

Além disso, a construção da Base de Dados Geoambientais trouxe inúmeras vantagens, no que se refere à melhoria da infra-estrutura de trabalho, à diminuição dos prazos de execução de projetos, e a conseqüente redução de custos. 


\section{Metodologia Empregada pela EESC/USP}

A metodologia baseia-se em linhas gerais nas etapas e finalidades da cartografia geoambiental realizada principalmente na Espanha. Entretanto, os documentos produzidos seguem os procedimentos utilizados pela cartografia geotécnica desenvolvida para as condições brasileiras propostas por Zuquette (1987), Zuquette \& Gandolfi (1990), Zuquette (1993) e Zuquette et al. (1997). Além disso, busca-se ainda com a utilização de SIG's (Sistemas de Informação Geográfica) a obtenção de algumas cartas, de forma a explorar seu potencial em cruzamentos automatizados.

A proposta metodológica da EESC/USP analisa basicamente os atributos do meio físico de caráter geomorfológico, geológico e de materiais inconsolidados (comportamento geotécnico), o que produz deste modo, uma série de documentos cartográficos geotécnicos, tais como: carta de declividades, mapa de landforms, mapa de substrato rochoso, mapa de materiais inconsolidados, etc.

Uma outra característica da metodologia aparece nos trabalhos de Grecchi (1998) e Lopes (2000). Os autores citados confeccionaram documentos cartográficos que avaliam potencialidades (aptidões) e limitações (susceptibilidades e processos geodinâmicos) do meio físico, conforme mostra a Figura 2.6, cruzando as cartas e mapas geotécnicos propostos pela metodologia da EESC/USP. Na obtenção desses produtos Grecchi (1998) e Lopes (2000) freqüentemente submetem os planos de informação envolvidos (substrato rochoso, materiais inconsolidados, declividades, etc) à análise multicriterial.

De acordo com Lopes (2000) este método de combinação utiliza os atributos através de uma ordenação hierárquica, em uma matriz de correlação paritária, comparando-se a importância relativa de cada atributo, frente ao processo em análise. Esse procedimento é realizado dentro do ambiente SIG, que no caso em questão se processa no Idrisi.

A proposta metodológica é aplicada em escalas consideradas regionais (Zuquette, 1993), geralmente 1:50.000. Tal procedimento objetiva, principalmente, contribuir com o planejamento territorial das áreas analisadas, desse modo realizando a análise geoambiental e apontado as potencialidades e limitações do meio físico frente a diversas solicitações. 

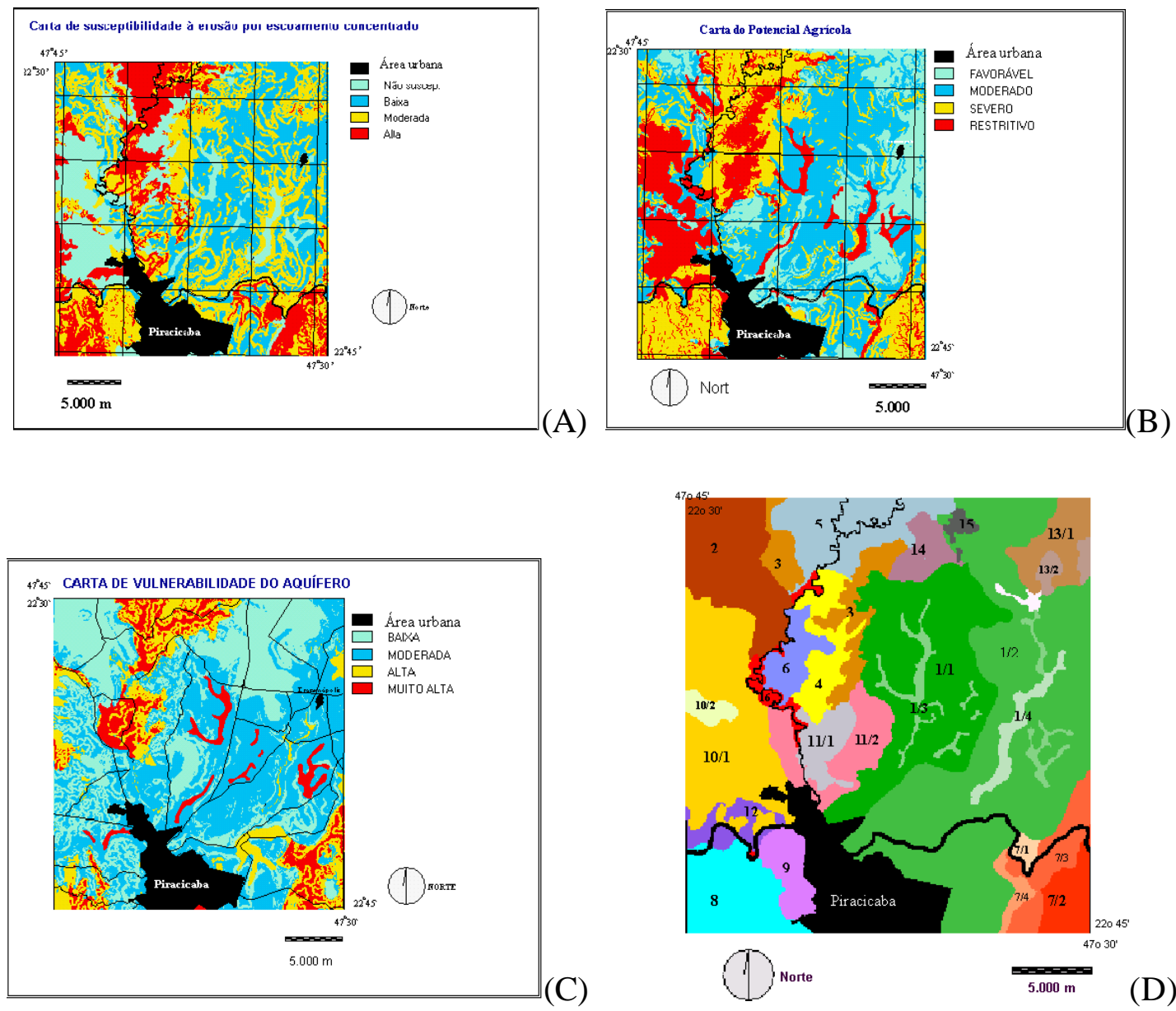

FIGURA 2.6 - Cartas geotécnicas produzidas para a região de Piracicaba (SP), onde:

(A) Carta de susceptibilidade à erosão por escoamento concentrado;

(B) Carta do Potencial Agrícola; (C) Carta de Vulnerabilidade do Aqüífero e (D) Carta de Zoneamento Geoambiental (Fonte: Grecchi $\&$ Pejon, 1998).

A metodologia da EESC/USP, sempre em seus estudos geoambientais procura sintetizar todas as informações colecionadas e produzidas em uma Carta de Zoneamento Geoambiental, esta realizada por meio da reclassificação das unidades de terreno (mapa de landforms) como mostra a Figura 2.7. 

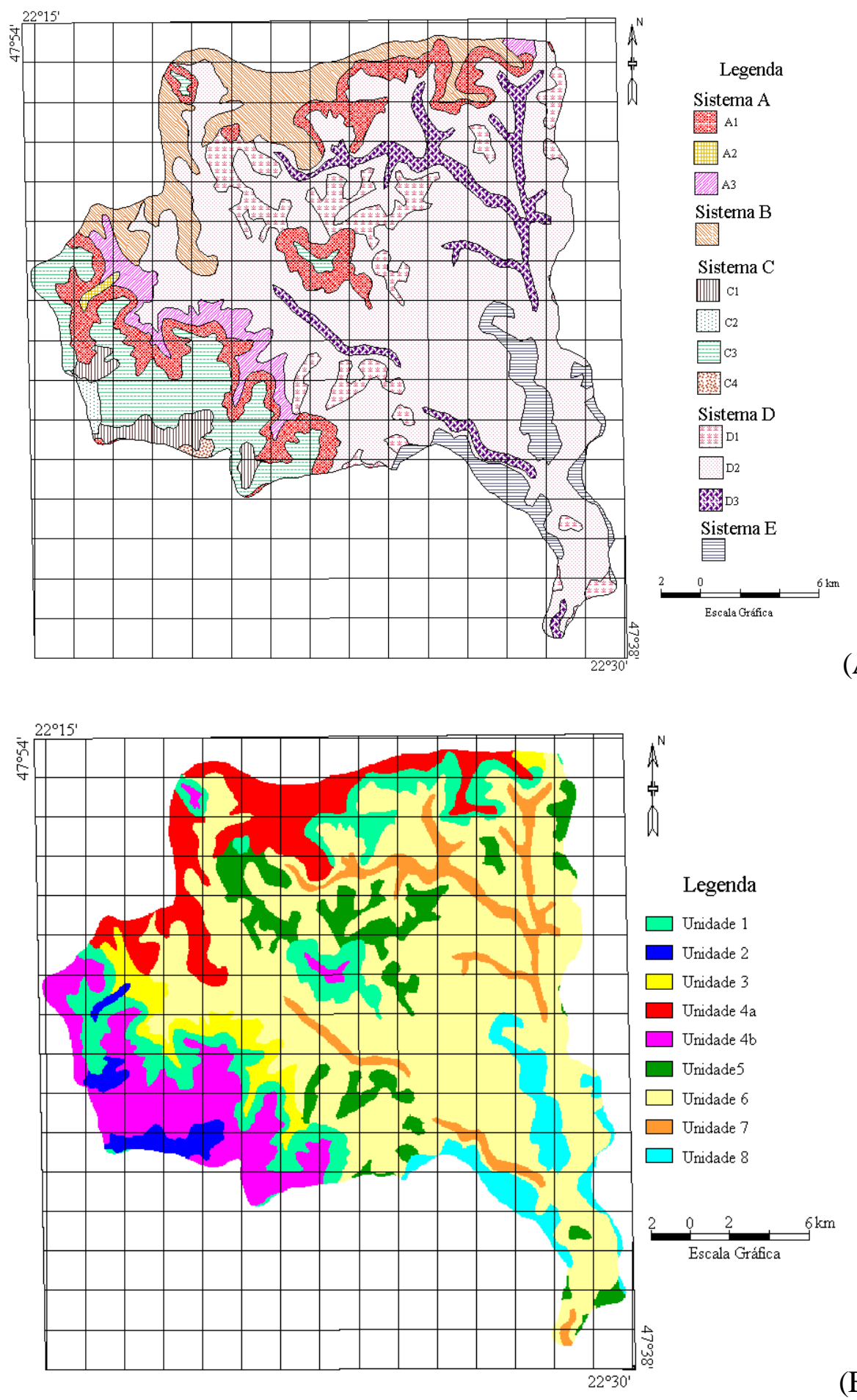

(A)

(B)

FIGURA 2.7 - Cartas geotécnicas produzidas para as bacias dos Rio Passa Cinco e Rio da Cabeça, ambos afluentes da margem direita do Rio Corumbataí (SP). O ítem (A) corresponde ao Mapa de Landforms enquanto (B) a Carta de Zoneamento Geoambiental (Fonte: Lopes \& Pejon, 2002). 


\subsection{Geoprocessamento}

O homem vive em um mundo de natureza espacial, sempre lidando diariamente com interações espaciais complexas que formam a maior parte de sua vida diária. Os indivíduos trabalham numa localidade, vivem em outra, interagem com outros indivíduos e instituições espalhadas por uma área substancial. Os seres humanos sempre se encontram tendo que tomar decisões que envolvem conceitos de distância, direção, adjacência, localização relativa e tantas outras mais complexas são tomadas, de modo geral, de maneira intuitiva. A partir dessa situação, o homem desenvolveu ao longo dos séculos o mapa, um modo eficiente de armazenar as informações sobre as complexas relações espaciais (Calijuri, 2000).

De acordo com Câmara \& Davis (1999) o geoprocessamento surgiu das primeiras tentativas de automatizar parte do processamento de dados com características espaciais na Inglaterra e nos Estados Unidos, nos anos 50, com o objetivo principal de reduzir custos de produção e manutenção de mapas.

Segundo Câmara \& Davis (1999) geoprocessamento é a disciplina do conhecimento que utiliza técnicas matemáticas e computacionais para o tratamento da informação geográfica e que vem influenciando de maneira crescente as áreas de cartografia, análise de recursos naturais, transportes, comunicação, energia e planejamento urbano e regional.

\subsubsection{Sistemas de Informação Geográfica}

Os sistemas de informação geográfica (SIG's) ou sistemas de geoprocessamento (Dias, 1993) são as ferramentas computacionais para o geoprocessamento que permitem realizar análises complexas, ao integrar dados de diferentes fontes e ao criar bancos de dados georeferenciados (Figura 2.8). 


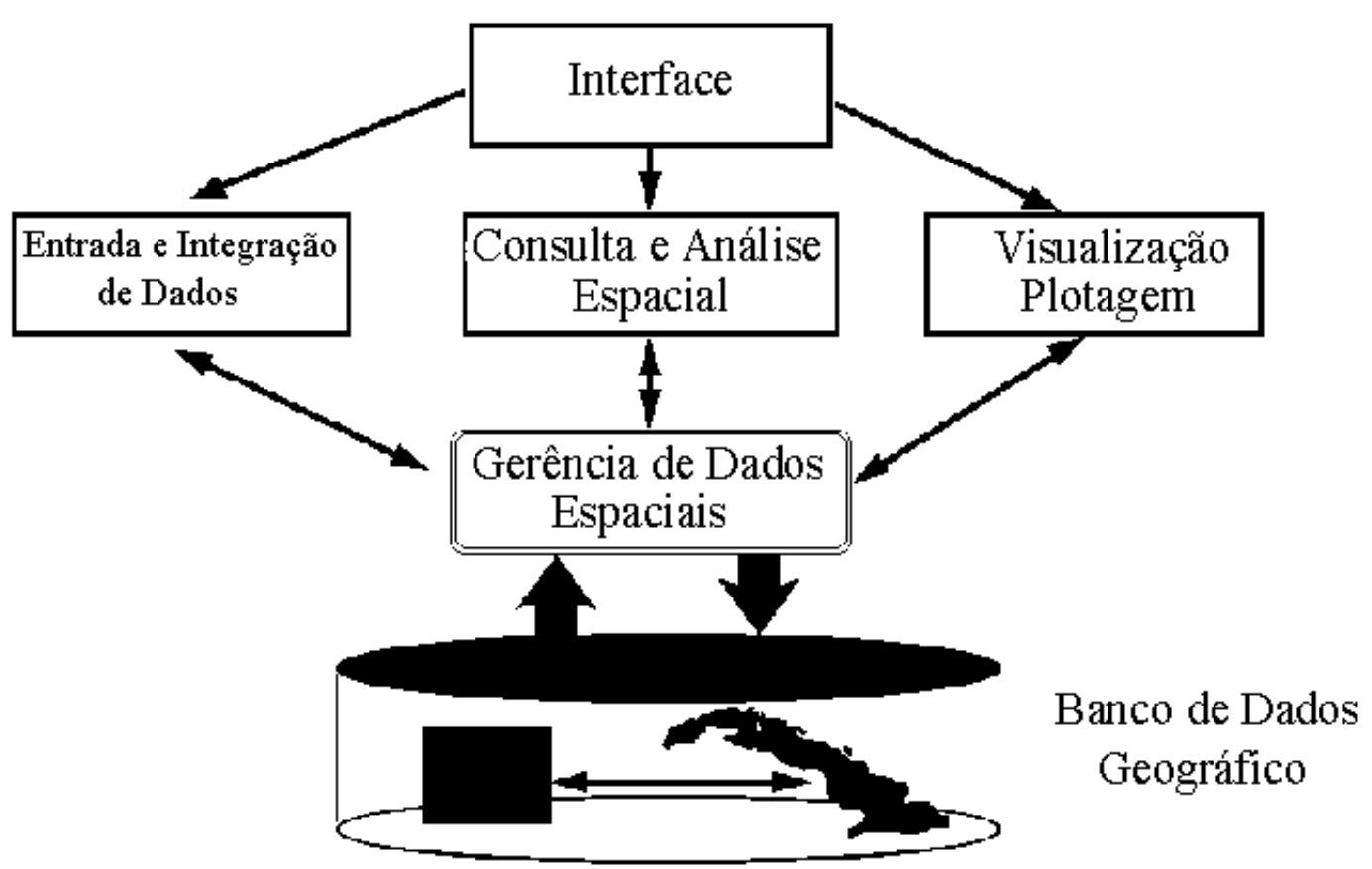

FIGURA 2.8 - Estrutura geral de sistemas de informação geográfica. (Fonte: Davis \& Câmara, 1999).

Existem inúmeras definições para SIG, eis alguns exemplos:

“O termo Sistemas de Informação Geográfica (SIG) é aplicado para sistemas que realizam o tratamento computacional de dados geográficos e recuperam informações não apenas com base em suas características alfanuméricas, mas também através de sua localização espacial; oferecem ao administrador (urbanista, planejador, engenheiro) uma visão inédita de seu ambiente de trabalho, em que todas as informações disponíveis sobre um determinado assunto estão ao seu alcance, interrelacionadas com base no que lhes é fundamentalmente comum -- a localização geográfica. Para que isto seja possível, a geometria e os atributos dos dados num SIG devem estar georeferenciados, isto é, localizados na superfície terrestre e representados numa projeção cartográfica" (Davis \& Câmara, 1999).

"Um SIG é um sistema auxiliado por computador para a aquisição, armazenamento, análise e visualização de dados geográficos" (Eastman, 1997). 
"Um sistema de Informação geográfica pode ser definido como uma coleção organizada de hardware, software, dados geográficos e pessoal envolvido no trabalho, projetada para, eficientemente capturar, armazenar, atualizar, manipular, analisar e representar todas as formas de informações referida geograficamente" (Calijuri, 2000).

Segundo Davis \& Câmara (1999) um SIG tem os seguintes componentes:

a) Interface com o usuário

b) Entrada e Integração de dados:

c) Funções de consulta e análise espacial;

d) Visualização e plotagem;

e) Armazenamento e recuperação de dados (organizados sob a forma de um banco de dados geográficos);

De acordo com Salazar Junior (1998) qualquer software de SIG deve contemplar as seguintes características principais descritas abaixo:

- Interface customizável;

- Entrada de dados flexível;

- Conversão de dados;

- Ambiente gráfico (CAD);

- Projeção de mapas;

- Transformação de sistemas de projeção;

- Ambiente de edição;

- Acesso a outras bases de dados tabulares;

- Geração de buffers;

- Consulta espacial e lógica;
- Atualização dinâmica de dados;

- Armazenamento de dados tabulares;

- Geocodificação e busca por endereço;

- Análises de redes;

- Modelagem de localização/alocação;

- Modelagem de superfícies;

- Modelagem raster;

- Análise de superfícies;

- Produção de mapas 
Segundo Calijuri (2000) pode-se realizar nos SIG's uma série de análises , tais como otimizar o sistema de transporte coletivo; avaliar a tendência preferencial de crescimento dos bairros; definir a forma pela qual se deve proceder ao avanço das redes de infraestrutura urbana (água, esgoto, pavimentação, iluminação, telefonia, etc); definir os locais estratégicos para a instalação de postos de saúde, hospitais, creches, escolas, áreas de lazer, áreas potenciais de ocupação residencial e industrial; avaliar a percentagem de cobertura natural e cultivada pelo homem; determinar a extensão de áreas industriais e residenciais, agrícolas, etc.

Zuquette et al.(1997) alertam os usuários de SIG na realização de operações de análise geográfica pois muitos profissionais vêm cometendo graves erros ao considerar que os SIG's, ou até mesmos programas similares, produzem informações diretas sobre o meio físico, ou que podem desconsiderar a obtenção de informação referente aos componentes ambientais. Tal tipo de procedimento provoca sérios prejuízos, uma vez que só reúnem recursos de desempenho, de tratamento estatístico e de banco de dados em um mesmo conjunto, e, portanto serão eficientes somente se o conjunto for utilizado para tratar um número significativo de atributos obtidos por procedimentos criteriosos, e que tenham validade para o tratamento areal.

Segundo Dias (1993), antes do uso do SIG, o tratamento das informações geográficas era composto por cadastros de dados informatizados e pelo cruzamento de planos de informação (atributos) de forma manual. Esse procedimento inibia o desenvolvimento de um grande número de aplicações, devido à evidente demora e alto custo homem/hora de desenvolvimento.

De acordo com Medeiros \& Camara (2002) o uso da tecnologia dos sistemas de informação geográfica apontam para quatro campos de atuação ligados aos Estudos Ambientais, são eles:

a) Mapeamento Temático: objetivam a caracterização e o entendimento da organização do espaço como ponto de partida para o estabelecimento das bases para ações e estudos futuros. Como exemplos podem-se citar levantamentos temáticos geológicos, geomorfológicos, pedológicos, de cobertura vegetal. 
b) Diagnóstico Ambiental: visam estabelecer estudos particulares sobre regiões de interesse, basicamente voltados a projetos de ocupação ou preservação. Incluem-se nessa categoria Relatórios de Impacto Ambiental (RIMAs) e os estudos visando o estabelecimento de Áreas de Proteção Ambiental (APAs).

c) Avaliação de Impacto Ambiental: objetivam o monitoramento dos resultados da intervenção humana sobre o ambiente. Levantamentos como o feito pelo SOS Mata Atlântica sobre o remanescente de floresta na costa leste brasileira é um exemplo de estudo de Avaliação de Impacto Ambiental

d) Ordenamento Territorial e os Prognósticos Ambientais: buscam normalizar a ocupação do espaço, procurando racionalizar a gestão do território, levando em consideração o conceito de desenvolvimento sustentado. (Zoneamentos Ecológico-Econômicos, Zoneamentos Geoambientais).

Devido as suas poderosas ferramentas de manipulação e análise de dados geográficos, tais como: análise geográfica (consulta ao banco de dados, operações boleanas e matemáticas entre mapas), processamento digital de imagens e modelagem numérica de terreno (geração de mapas de declividade, visualização 3D, cálculos de volumes) diversos estudos geoambientais vêem utilizando os SIGs, atuando principalmente nos campos de mapeamento temático e ordenamento territorial (Grecchi, 1998; Lopes, 2000). 


\subsection{Análise de Agrupamentos de Informações Geoambientais (Cluster}

\section{Analysis)}

De acordo com Landim (2001) a análise de agrupamentos (cluster analysis) é um termo usado para descrever uma infinidade de técnicas numéricas cujo objetivo principal é classificar os valores de uma matriz de dados sob estudo em grupos discretos. Tal técnica classificatória multivariada pode ser utilizada quando se deseja explorar as similaridades entre indivíduos (modo Q) ou entre variáveis (modo R) definindo-os em grupos, considerando simultaneamente, no modo $\mathrm{Q}$, todas as variáveis medidas em cada indivíduo e, no modo $\mathrm{R}$, todos os indivíduos nos quais foram feitas as mesmas mensurações.

Ainda segundo o autor, dentre as técnicas numéricas de análise de agrupamentos empregadas em geologia, os métodos por agrupamentos hierárquicos são os mais utilizados. Nesses, a partir da matriz inicial de dados obtém-se uma matriz simétrica de similaridades e inicia-se a detecção de pares de casos com a mais alta similaridade, ou a mais baixa distância; para essa combinação, segundo níveis hierárquicos de similaridade, escolhe-se entre os diversos procedimentos aglomerativo de tal modo que cada ciclo de agrupamento obedeça a uma ordem sucessiva no sentido do decréscimo de similaridade.

Landim (2001) destaca que os coeficientes de similaridade representam o grau de semelhança entre pares de objetos e como os mesmos deverão ser arranjados de acordo com os respectivos graus de similaridade de modo a ficarem agrupados segundo uma disposição hierárquica. Os resultados quando organizados em gráfico, do tipo dendrograma, mostrarão as relações das amostras agrupadas.

$\mathrm{Na}$ análise introdutória de matrizes de dados, a análise de agrupamentos se torna bastante eficiente para auxiliar na formulação de hipóteses a respeito da homogeneidade de dados de natureza multivariada, o que vem a ajudar quão se quer analisar, por exemplo quanto essa homogeneidade se desenvolve entre atributos do meio físico levantados em estudos ambientais, principalmente pela variabilidade e quantidade de dados manipulados nestes estudos. 


\section{CAPÍTULO 3 - MATERIAIS E MÉTODOS}

\subsection{Métodos de Trabalho}

O método de trabalho empregado nessa pesquisa, cuja finalidade é desenvolver um zoneamento geoambiental para área estudada associando a esse a utilização de SIG's, baseou-se na proposta metodológica de desenvolvimento da cartografia geotécnica para as condições brasileiras de Zuquette (1987), Zuquette \& Gandolfi (1990), Zuquette (1993) e Zuquette et al. (1997).

Assim, por meio de trabalhos de gabinete, campo e laboratório foram produzidos oito documentos cartográficos geotécnicos (mapas de documentação, substrato rochoso, materiais inconsolidados, landforms, uso e ocupação além das cartas de declividades, potencial agrícola e zoneamento geoambiental) integrados a dois sistemas de informação geográfica, um baseado no formato vetor (ArcView 3.1) e o outro no raster (Idrisi 32).

\subsubsection{Trabalhos de Gabinete}

Os trabalhos de gabinete tiveram diversas etapas, são elas: revisão bibliográfica; elaboração dos produtos cartográficos geotécnicos preliminares; obtenção dos dados, tratamento e análise das informações; integração das informações produzidas aos sistemas de informação geográfica Idrisi 32 e ArcView 3.1; produção dos produtos cartográficos geotécnicos intermediários e dos definitivos; realização do zoneamento geoambiental para área em estudo e redação final da pesquisa. 
É importante frisar que essas etapas não foram realizadas de modo seqüencial como previamente definido (excetuando as duas primeiras) em razão da atuação de um complexo conjunto interativo, de modo que, à medida que novas informações eram adicionadas aos sistemas de informação geográficas essas acabavam influenciando em todos os passos (Figura 3.1).

Durante a fase de revisão bibliográfica foram levantadas informações tanto acerca de metodologias de zoneamento geoambientais baseados em estudos geológicos-geotécnicos, quanto de estudos de caracterização do meio físico para a área pesquisada.

Os resultados dessa etapa apontaram que o zoneamento geoambiental deveria tomar como base a proposta metodológica de desenvolvimento da cartografia geotécnica para as condições brasileiras de Zuquette (1987), Zuquette \& Gandolfi (1990), Zuquette (1993) e Zuquette et al. (1997).

Com relação a caracterização do meio físico, foram selecionados os estudos de Cavalcante et al. (1979), IPT (1981), PROJETO RADAMBRASIL (1983), Oliveira et al. (1983) e Liporaci (1994). Em complemento a esta fase foram adquiridas cartas topográficas, fotografias aéreas, imagens de satélite da área além de fichas de campo por meio de consulta ao banco de dados da CPRM.

De posse desses dados foram produzidos, a partir de fotointerpretação, os mapas preliminares de landforms e substrato rochoso, onde este último contou com a compilação dos documento produzidos por Oliveira et al. (1983) e Liporaci (1994).

A medida que os trabalhos de campo e de laboratório foram se desenvolvendo, através das etapa de tratamento e análise das informações com integração aos SIG's Idrisi 32 e ArcView 3.1, foram superaras as diversas fases intermediárias de construção dos documentos cartográficos, desse modo foi obtido como produto final o conjunto cartográfico geotécnico formados por cinco mapas e três cartas.

As últimas etapas de gabinete realizadas foram acerca do desenvolvimento da metodologia de construção da carta de zoneamento final e da redação final do texto da dissertação. 


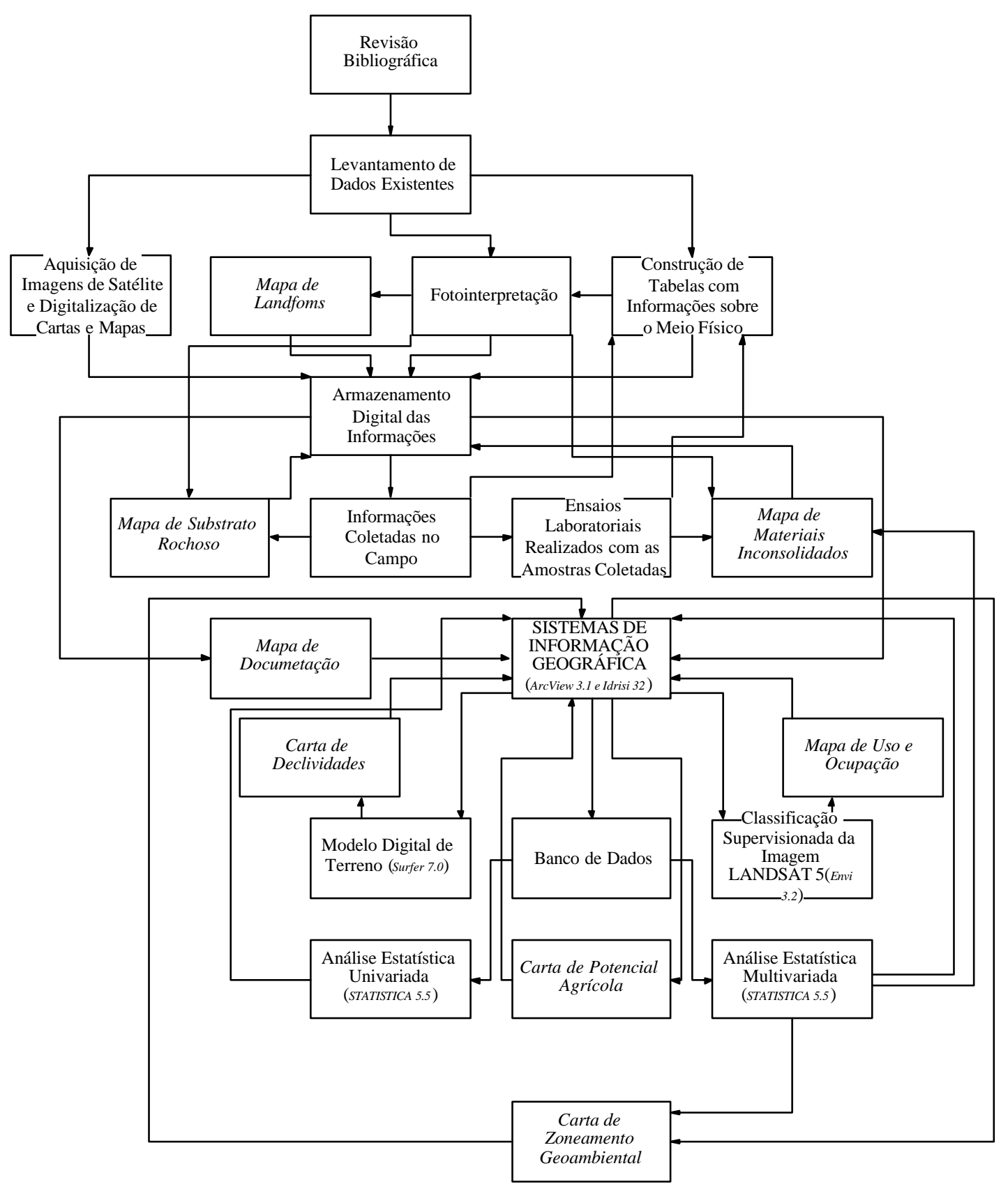

FIGURA 3.1 - Fluxograma mostrando as diversas interações entre as etapas de trabalho executadas na pesquisa.

O detalhamento dos procedimentos utilizados para elaboração de cada um dos documentos cartográficos geotécnicos está descrito nos capítulos 5 (Obtenção dos Dados, Tratamento e Análise das Informações) e 6 (Carta de Zoneamento Geoambiental). 


\subsubsection{Trabalhos de Campo}

Os trabalhos de campo foram realizados com o objetivo de caracterizar o meio físico quanto aos componentes avaliados nessa pesquisa (substrato rochoso, materiais inconsolidados e landforms) além do padrão de uso e ocupação e a presença de eventos geodinâmicos na área estudada.

Desse modo, com relação ao substrato rochoso, foram analisados vários aspectos como litologia predominante, mineralogia, cor, padrão e grau de fraturamento. Os materiais inconsolidados, por sua vez, foram caracterizados quanto a sua origem, cor, espessura, composição textural, homogeneidade e grau de intemperismo de acordo com a proposta da GEOLOGICAL SOCIETY (1995) como mostra a Figura 3.2. As unidades de terreno, delimitadas para o mapa de landforms, a partir dos trabalhos de campo, tiveram os seus perfis geológico-geotécnicos definidos e descritos.

\subsubsection{Trabalhos de Laboratório}

Os trabalhos de laboratório se desenvolveram exclusivamente sobre as amostras de materiais inconsolidados deformadas e indeformadas, onde estas ultimas foram obtidas no campo a partir de anéis de PVC de diâmetro em torno de 7,45 cm e altura de 4,65 cm, segundo proposto por Zuquette (1987).

Além dos ensaios de granulometria conjunta (ABNT NBR 7181), fundamentais na classificação dos materiais inconsolidados, esses materiais também foram caracterizados em função de sua capacidade de troca catiônica (CTC), de acordo com Pejon (1992), a partir do ensaio de azul de metileno.

Valores de massa específica dos sólidos (ABNT NBR 6508) foram determinados para todos os pontos amostrados. Nos locais onde houve a coleta de amostras indeformadas foram obtidos outros índices físicos como massa específica seca $\left(\rho_{d}\right)$, índice de vazios $(e)$, porosidade $(n)$ e grau de saturação $\left(S_{r}\right)$. 
FICHA DE CAMPO

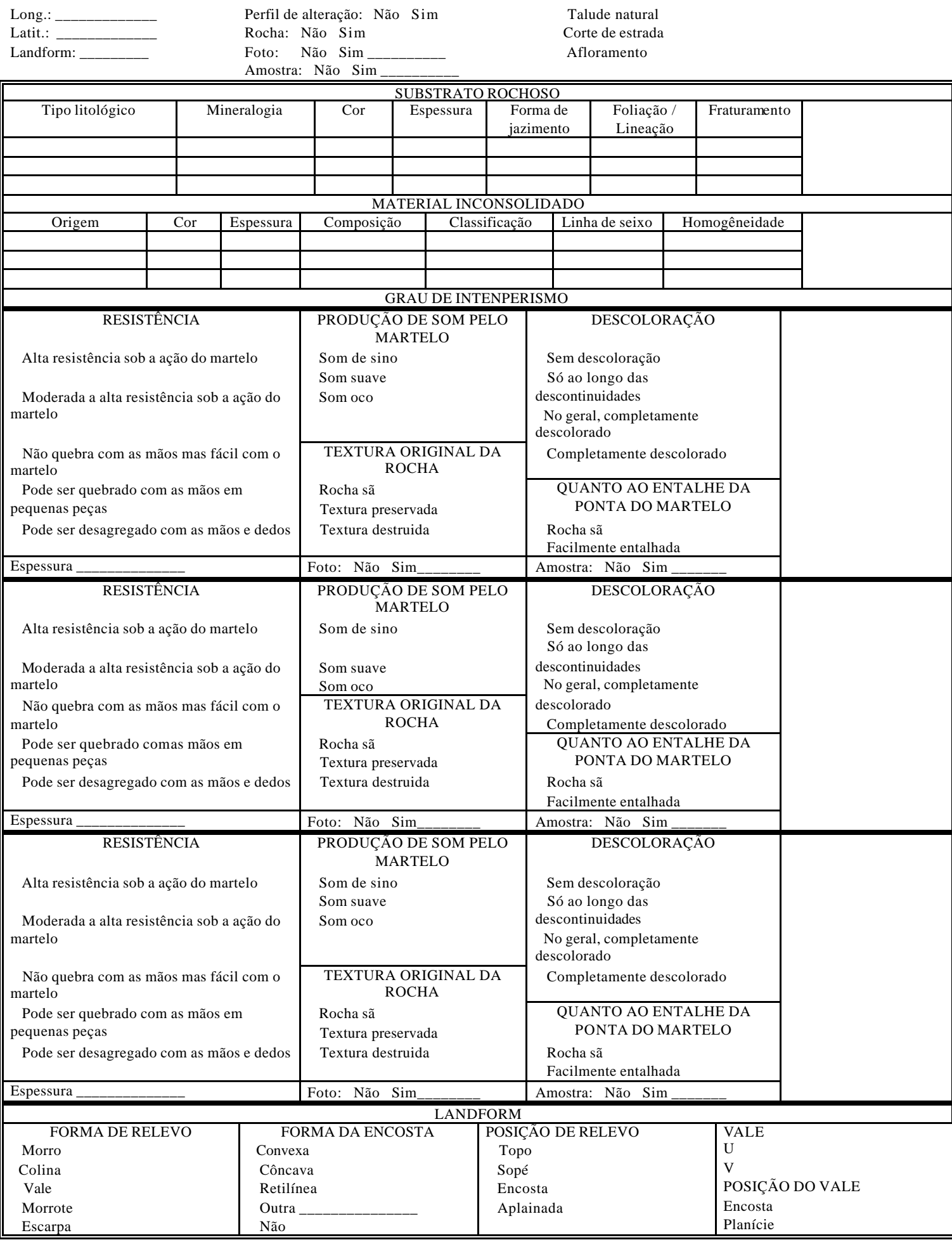

\begin{tabular}{|l|l|l||}
\hline \multirow{1}{|c||}{ USO } & PROCESSO GEODINÂMICO ASSOCIADO & OBSERVAÇÕES \\
Residenc. urbano & Escorregamento & \\
Residenc. rural & Erosão & \\
Turístico & Assoreamento & \\
Industrial & Inundação & \\
Pasto & \multicolumn{1}{|c||}{ INFORMAÇÕES ADICIONAIS } & \\
Plantio & Solo Não Sim & \\
Exploração mineral & N.A. Não Sim & \\
\hline
\end{tabular}

FIGURA 3.2 - Ficha de campo utilizada na pesquisa. 


\subsection{Materiais Utilizados}

Os mapas, as cartas, as fotografias aéreas, as imagens de satélite, os equipamentos de campo e os softwares utilizados para execução dessa pesquisa apresentam-se listados abaixo:

\section{Documentos Cartográficos}

$\checkmark$ Folhas topográfica publicada pelo IBGE (escala 1:50.000) de Caconde (SF-23 VC-VI-2)

$\checkmark$ Folhas topográfica publicada pelo IBGE (escala 1:50.000) de Botelhos (SF-23-VD-IV-1)

$\checkmark$ Folhas topográfica publicada pelo IBGE (escala 1:50.000) de Poços de Caldas (SF-23 V-C-VI-4)

$\checkmark$ Folhas topográfica publicada pelo IBGE (escala 1:50.000) de Caldas (SF-23-VD-IV-1).

$\checkmark$ Mapa geológico das porções paulista das quadrículas de Caconde e Guaxupé na escala 1: 50.000 (Oliveira et al., 1983)

$\checkmark$ Mapa de substrato rochoso de parte do Município de Poços de Caldas (MG) escala: 1:25.000 (Liporaci, 1994)

\section{Fotografias Aéreas}

$\checkmark$ trinta e três fotografias aéreas convencionais da FAB/USAF obtidas por meio de vôos realizados entre 1964 e 1966 executados com escala aproximada de 1:60.000.

\section{Imagens de Satélites}

$\checkmark$ sete imagens do LANDSAT 5 (uma para cada banda) datadas de setembro de 1999.

\section{$\underline{\text { Equipamentos Utilizados nas Etapas de Campo }}$}
$\checkmark$ Martelo geológico
$\checkmark$ Bússola Brunton
$\checkmark$ Máquina Fotográfica
$\checkmark$ Aparelho de GPS 
$\checkmark$ Sacos Plásticos $(20$ x $40 \mathrm{~cm})$

$\checkmark$ Anéis de PVC $(7,45 \times$ 4,65 cm)

$\checkmark$ Um Par de Espátulas

\section{$\underline{\text { Principais Softwares Utilizados na Pesquisa }}$}

$\checkmark$ AutoCad Map ® 2000 - Digitalização dos planos de informações.

$\checkmark$ Idrisi ® 32 - Cálculo da declividade e operações matemáticas utilizando os diversos planos de informações.

$\checkmark$ ArcView GIS ® 3.1 - Banco de dados associados aos planos de informações.

$\checkmark$ Envi ${ }^{\circledR} 3.2$ - Processamento Digital de Imagens.

$\checkmark$ Statistica $\AA^{\circledR} 5.5$ - Analises estatísticas com dados univariados e multivariados.

$\checkmark$ Surfer ${ }^{\circledR} 7.0$ - Modelagem digital de terreno. 


\section{CAPÍTULO 4 - CARACTERIZAÇÃo GERAL DA ÁREA EM ESTUDO}

\subsection{Localização, Tamanho da Área e Acesso}

O local objeto dessa pesquisa situa-se à nordeste do Estado de São Paulo incluindo porção do Município de Caconde (SP), estendendo-se para parte dos Municípios de Botelhos e Poços de Caldas no Estado de Minas Gerais (Figura 4.1).

A área estudada localiza-se entre as coordenadas $324 \mathrm{~km}$ e $360 \mathrm{~km}$ UTM (EW) e 7580 km e 7616 km UTM (NS) pertencentes à Zona 23 do Hemisfério Sul tendo como Datum Horizontal o de Córrego Alegre (MG) e o Vertical o de Marégrafo Imbituba (SC). O Elipsóide de referência é o .SAD-69.

A área de pesquisa compreende a superfície da sub-bacia hidrográfica representada pelo conjunto de drenagens da Bacia do Rio Pardo direcionadas ao reservatório da Hidroelétrica de Caconde, excetuando a área de drenagem da Represa de Bortolan (Poços de Caldas, MG), o que totaliza 482,31 km².

O acesso pode ser feito através da Cidade de Campinas (SP) pela Rodovia Anhanguera no sentido do interior do Estado de São Paulo até o Km 134. Nesse ponto, o acesso continua pela rodovia estadual SP 340 até a Cidade de Águas da Prata (divisa como Estado de Minas Gerais). No lado mineiro, o acesso continua pela rodovia federal BR 267 até a Cidade de poços de Caldas onde se atinge a porção sul da área estudada. 


\subsection{Clima}

O clima segundo Cavalcante et al. (1979) é classificado de acordo com a classificação de Köppen como tropical úmido, esse caracterizado por uma estação seca (julho à setembro) e uma chuvosa bem definida (dezembro à fevereiro).

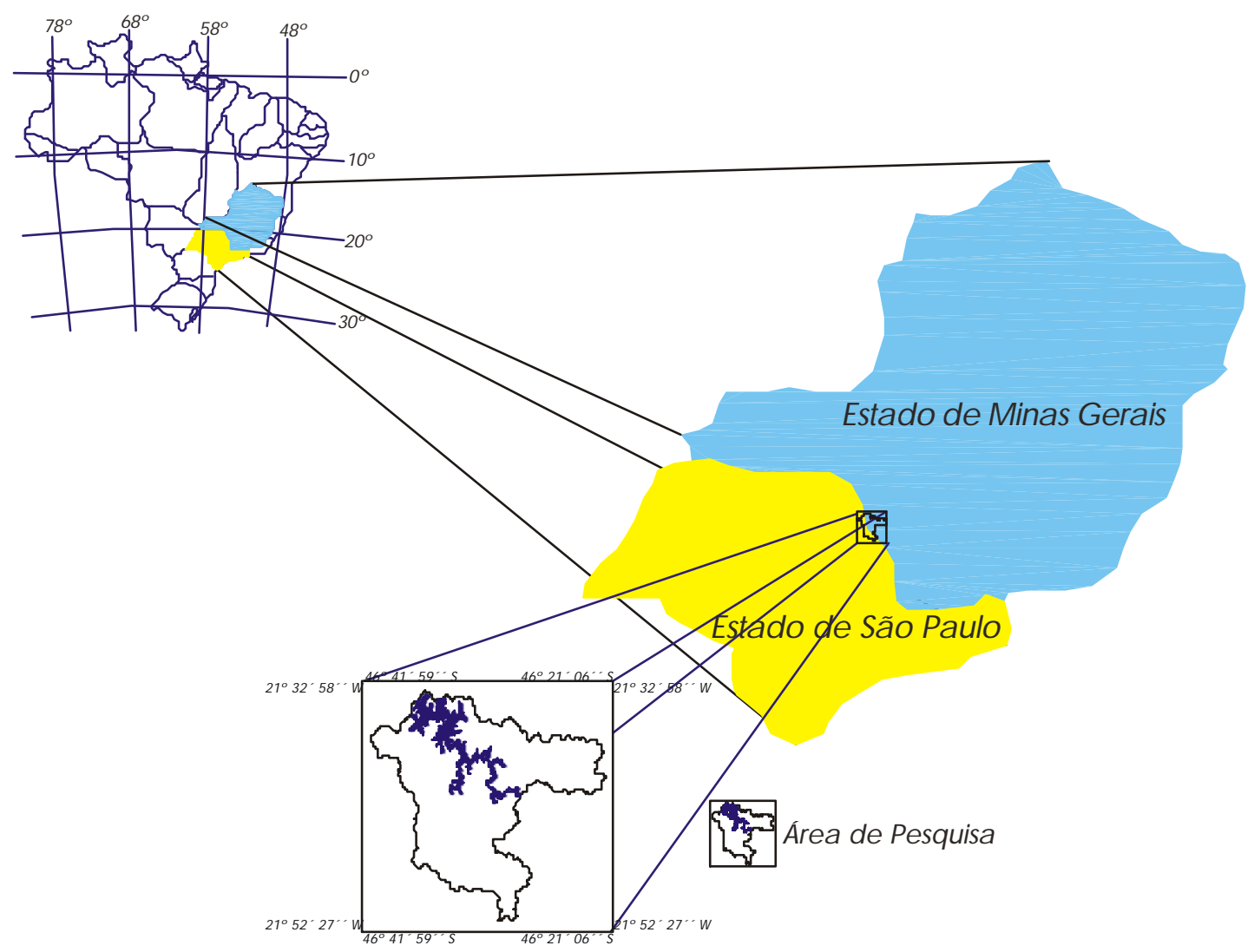

FIGURA 4.1 - Localização da área em estudo.

A região apresenta pequenas variações pluviométricas e de temperatura. A temperatura média do mês mais frio é inferior a $18^{\circ} \mathrm{C}$ e a do mês mais quente $22^{\circ} \mathrm{C}$. $\mathrm{O}$ índice pluviométrico anual varia entre $1.100 \mathrm{~mm}$ e $1.700 \mathrm{~mm}$ (PROJETO RADAMBRASIL, 1983). 


\subsection{Vegetação}

De acordo com Lima (1966) apud Cavalcane et al. (1979) a cobertura vegetal da área estudada é representada pela Floresta Mesófila, que corresponde a uma formação florestal estacional, latifoliada, subcaducifólia. Seus tipos vegetais mais comuns são: o cedro, a figueira e o pau d'alho.

Em proporções quantitativas, a vegetação nativa quase não pode ser mais observada, o intenso uso e ocupação humana promoveram a substituição da cobertura vegetal original pelos campos de pastagem e áreas de lavoura (principalmente café). Os resquícios de floresta são praticamente só encontrados nas encostas com altas declividades.

\subsection{Solos}

Segundo Cavalcante et al. (1979) na região estudada em função da influência de um clima relativamente quente e de precipitações abundantes, que promovem a lixiviação dos elementos solúveis e o acúmulo de ferro e alumínio, predominam fundamentalmente os latossolos.

O latossolo mais comum é o do tipo vermelho-escuro, esse caracterizado por apresentar um horizonte B latossólico (espesso e homogêneo) de coloração vermelha onde a textura varia de média a argilosa. Em diversas porções sobre as litologias do maciço alcalino, onde se desenvolveram intensos processos alteração secundária, é possível encontrar a presença de grandes depósitos lateríticos.

\subsection{Geomorfologia}

O contexto geomorfológico, de acordo com o IPT (1981), é formado pelo Planalto Atlântico, especificamente pela porção norte da Serrania de Lindóia, e o Planalto de Caldas. 
$\mathrm{Na}$ Serrania de Lindóia o relevo é caracterizado por Serras Alongadas e Morros de Serras Restritas. Os primeiros são formados por elevações de topos angulosos, vertentes ravinadas e de perfis retilíneos, por vezes abruptas formando vales fechados e apresentando alta densidade de drenagem. Os Morros de Serras Restritas constituem-se de morros com topos arredondados, vertentes retilíneas abruptas, com alta densidade de drenagem em padrão dendrítico a pinulado com vales fechados e planícies aluvionares interiores restritas.

No Planalto de Poços de Caldas as formas de relevo são condicionadas pelo Maciço Alcalino de Poços de Caldas, sendo a porção interna do relevo marcada por um relevo de Mar de Morros e as bordas deste marcada por Linhas de Crista de Escarpa.

\subsection{Geologia Regional}

Em termos regionais, de acordo com Cavalcante et al. (1979), o contexto geológico da área de pesquisa é representado pelas rochas pré-cambrianas do Complexo Varginha e as rochas do Complexo Alcalino de Poços de Caldas, estas formadas na transição dos períodos Cretáceo Superior/Terciário (Mesozóico/Cenozóico).

As litologias que predominam no Complexo Varginha são granulitos ácidos e básicos, gnaisses granitóides diversos, gnaisses graníticos e anfibolíticos e com menor expressão quartzitos, rochas cálcio-silicáticas e mármores. No Complexo Alcalino de Poços de Caldas a predominância petrográfica é de foiaítos, fonólitos, tinguaítos e rochas potássicas.

Do ponto de vista geológico-estrutural, no que se refere as relações de contato com outros complexos, no Complexo Varginha processam-se por falhas de grande envergadura, observadas ou prováveis, estas últimas traduzindo-se em lineamentos marcados por xistificação, recristalizações superpostas e ação hidrotermal pegmatítica. 
Ainda segundo Cavalcante et al. (1979), a fase vulcânica alcalina de Poços de Caldas está intimamente relacionada aos movimentos verticais de grande amplitude que atingiram o Complexo Varginha durante o Terciário. Tal atividade resultou no desenvolvimento de uma intensa atividade hidrotermal e de um padrão de flaturamento radial que pode ser facilmente observado ao longo de todo Maciço Alcalino.

\subsection{Aspectos Sócio-econômicos}

A área em estudo abrange o município paulista de Caconde e os mineiros de Botelhos e Poços de Caldas, entretanto engloba somente as sedes municipais dos dois últimos.

Em Botelhos, de acordo com dados do censo do IBGE (2000), a população do município é de 15.103 habitantes. A parcela economicamente ativa se distribui principalmente nos setores agropecuário, extração vegetal e pesca, seguida pela atividade industrial, comércio de mercadorias, transporte e comunicações. A infra estrutura educacional conta somente com o ensino básico e fundamental. $\mathrm{O}$ município possui um único hospital mantido pelo Sistema Único de Saúde (SUS).

Ainda segundo o censo do IBGE (2000), o Município de Poços de Caldas possui uma população de 135.343 habitantes. O setor industrial é o que mais emprega a parcela da população economicamente ativa, sendo seguido pelo comércio de mercadorias, agropecuário, extração vegetal, pesca, transporte e comunicações. Do ponto de vista educacional o município conta com o ensino básico, fundamental, profissionalizante e superior. O serviço de saúde apresenta quatro hospitais o que totaliza 651 leitos. 


\section{CAPÍTULO 5 - OBTENÇÃO DOS DADOS, TRATAMENTO E ANÁLISE DAS INFORMAÇÕES}

\subsection{Documentos Cartográficos Elaborados}

Para esse trabalho os documentos cartográficos elaborados (todos na escala 1:50.000 e no formato CAD) foram concebidos baseando-se na proposta metodológica de desenvolvimento da cartografia geotécnica para as condições brasileiras de Zuquette (1987), Zuquette \& Gandolfi (1990), Zuquette (1993) e Zuquette et al. (1997).

Tal proposta se fundamenta na produção e análise de um conjunto de documentos cartográficos que tem o objetivo de representar o meio físico a partir dos seus principais atributos. Além disso, permite o zoneamento de uma área em função do cruzamento dos documentos cartográficos produzidos, apontando suas potencialidades e restrições dependendo da solicitação a qual é submetida.

\subsubsection{Mapa de Documentação}

O mapa de documentação (ANEXO I) apresenta informações relativas à rede hidrográfica, à malha viária, à topografia, ao perímetro urbano, ao limite da área em estudo além dos pontos visitados que foram utilizados na pesquisa.

A construção do mapa de documentação se iniciou com a seleção e o escaneamento dos elementos gráficos (Figura 5.1) presentes nas folhas topográficas publicadas pelo IBGE (escala 1:50.000) de Caconde (SF-23 V-C-VI-2), Botelhos (SF-23-V-D-IV-1), Poços de Caldas (SF-23 V-C-VI-4) e Caldas (SF-23-V-D-IV-1). 


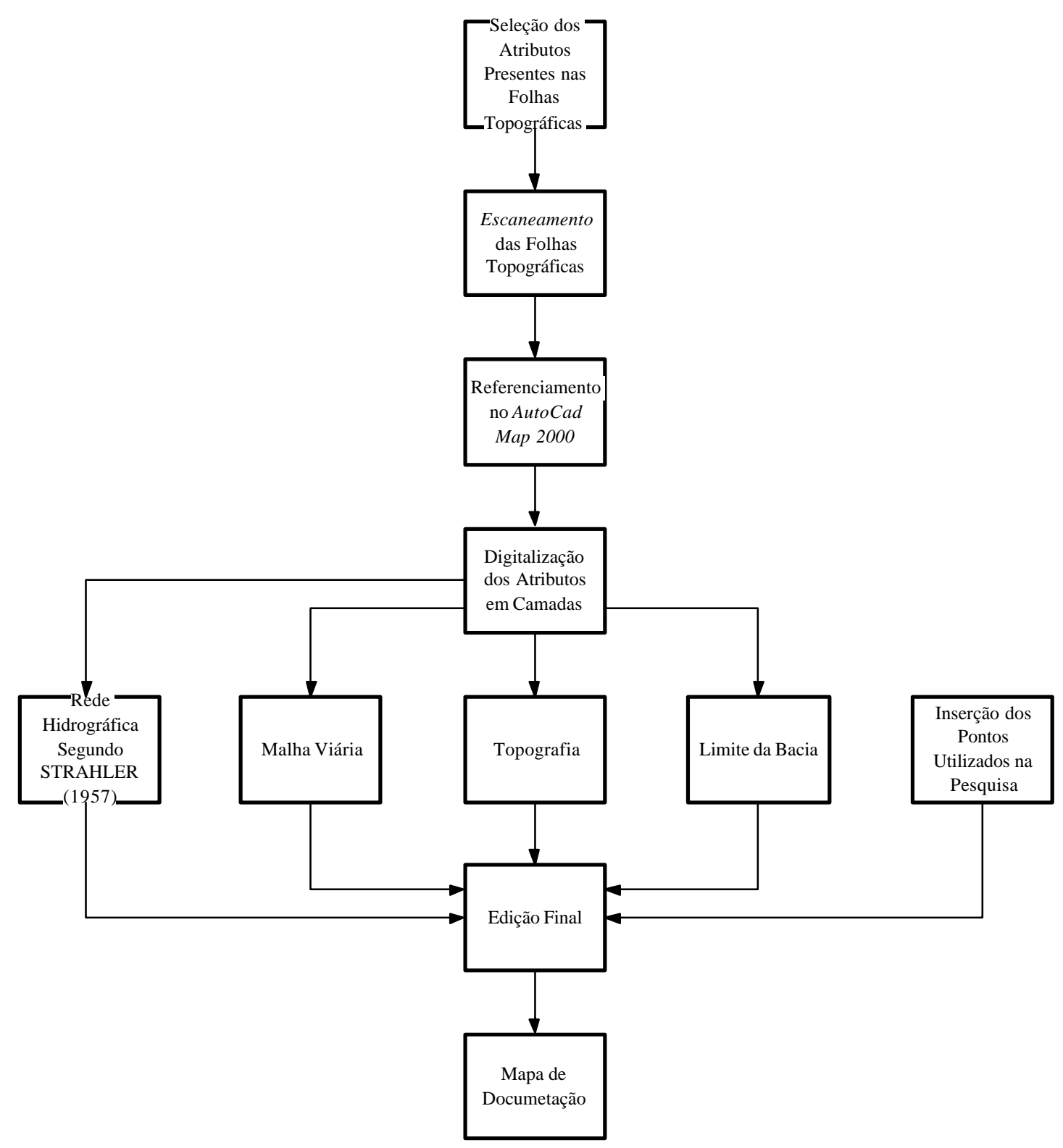

FIGURA 5.1 - Etapas seguidas para a construção do Mapa de Documentação.

Superadas essas etapas, as folhas topográficas foram referenciadas e tiveram digitalizados seus atributos previamente escolhidos (rede hidrográfica, malha viária, topografia, perímetro urbano, limite da área em estudo) utilizando o software AutoCAD Map® 2000. 
Os procedimentos seguidos para a digitalização das folhas topográficas foram os mesmos que convencionalmente são adotados para os trabalhos desenvolvidos em cartografia geotécnica pela EESC-USP (Lopes, 2000). Contudo, especificamente para a rede hidrográfica os canais fluviais foram digitalizados em diferentes camadas de acordo com a hierarquização estabelecida Strahler (1957), conforme mostra a Figura 5.2.

A etapa seguinte se concentrou na inserção dos pontos visitados utilizados na pesquisa, totalizando um número de 134 . Vinte destes pontos são provenientes de informações preexistentes obtidas a partir da consulta do banco de dados da CPRM (sistema MICROSIR). Os outros 114 pontos procedem das etapas de campo realizadas, sendo que em 52 destes foram coletadas amostras de materiais inconsolidados para serem submetidas a ensaios laboratoriais.

O último estágio na construção do mapa de documentação foi a edição final das camadas que compõem o arquivo (edição das curvas que pertencem a bacia, ajustes no tipo e tamanho de fontes que compõem a legenda, etc).

\subsubsection{Carta de Declividades}

A carta de declividades (ANEXO II) é um documento cartográfico imprescindível e indispensável para o estudo de uma área do ponto de vista geotécnico, pois fornece informações sobre a inclinação do terreno de maneira prática e de fácil uso.

A carta de declividades pode ser onfeccionada por meios convencionais (construção e uso de ábaco) apresentados por De Biasi (1970), Aguiar \& Kreling (1984), De Biase (1992) e Sanchez (1993) ou por meios computadorizados (uso de algoritmos) através de SIG's.

Meios convencionais e computadorizados possuem vantagens e desvantagens. Assim, cabe ao usuário decidir por um ou por outro meio, dependendo da finalidade e do tempo disponível para a execução (Tabela 5.1). Para esse trabalho, optou-se pela utilização de meios computadorizados uma vez que se considerou superados seus aspectos não vantajosos. 


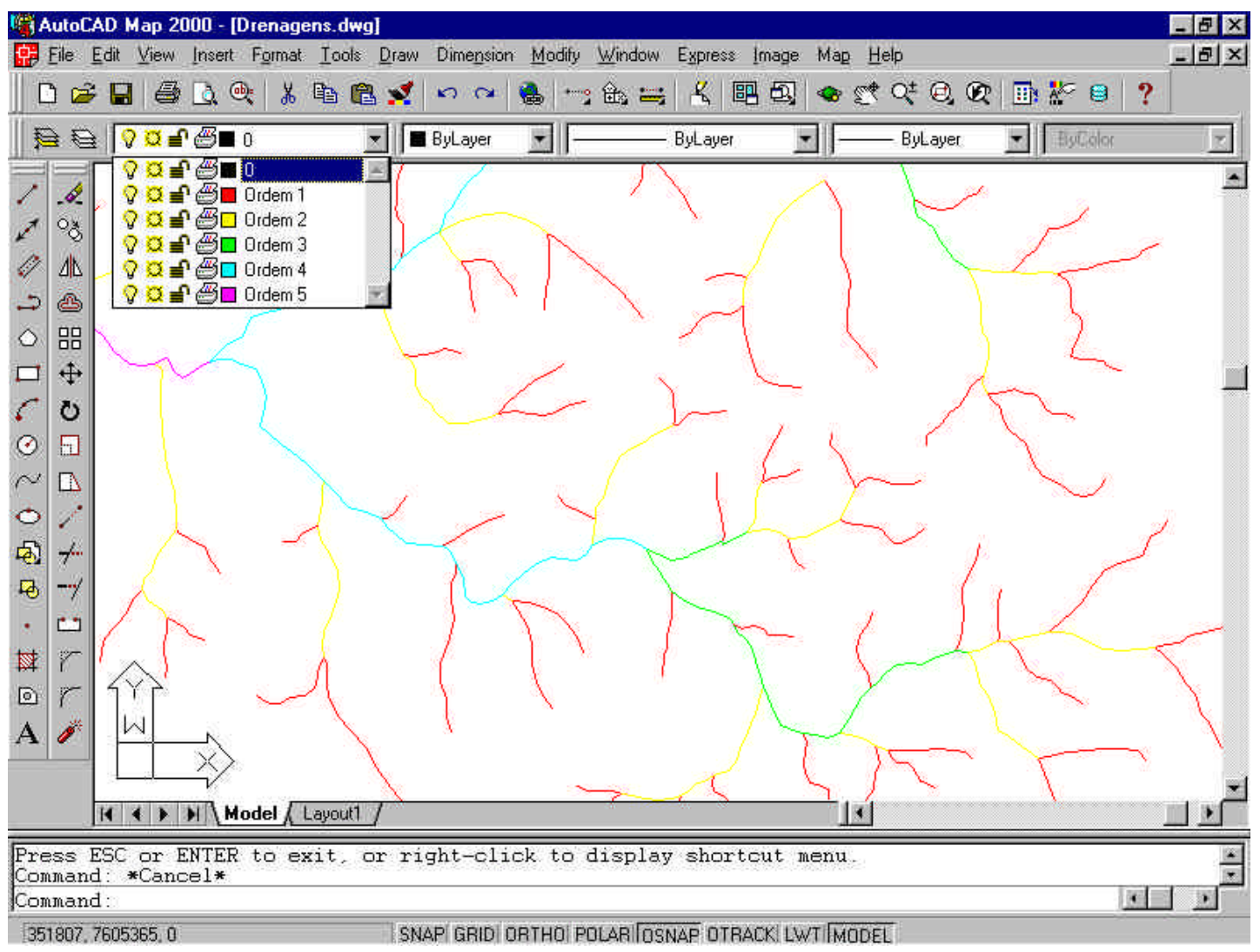

FIGURA 5.2 - Hierarquização da rede hidrográfica e digitalização em diferentes camadas.

A maioria dos algoritmos, nos SIG's, responsáveis pela geração da declividade exigem uma grande quantidade de informações altimétricas. Basicamente os SIG's utilizam dados extraídos de arquivos matriciais (malha regular) dos modelos numérico de terreno (MNT's), estes, frutos da interpolação de arquivos vetoriais que contém curvas de nível e pontos cotados.

O estágio primário de preparação da carta de declividades iniciourse aproveitando-se a digitalização das camadas do atributo topográfico realizada anteriormente para o mapa de documentação (Figura 5.3). O arquivo, que a princípio possuía outros atributos (rede hidrográfica, malha viária, etc.) e estava no formato DWG, foi salvo em nova versão com o formato DXF, somente com as camadas relativas as cotas das curvas de nível e dos pontos cotados. 
TABELA - 5.1 Comparação entre vantagens e desvantagens na construção da carta de declividades por meios convencionais e computacionais.

\begin{tabular}{|c|c|c|}
\hline & Vantagens & Desvantagens \\
\hline $\begin{array}{l}\text { Meios Convencionais } \\
\text { (construção e uso de } \\
\text { ábacos) }\end{array}$ & \begin{tabular}{|lll}
$\checkmark$ & Requer um período de \\
tempo mais curto na \\
confecção Quando a carta \\
possuir poucas classes de \\
declividades. \\
$\checkmark$ & A carta é sempre construída \\
& com sucesso.
\end{tabular} & $\begin{array}{l}\text { O aumento no número de } \\
\text { classes de } \\
\text { acresce declividades } \\
\text { construção da carta. } \\
\text { O usuário não pode modificar } \\
\text { o número de classes de } \\
\text { declividades uma vez } \\
\text { iniciado o processo de } \\
\text { confecção da carta. }\end{array}$ \\
\hline $\begin{array}{l}\text { Meios } \\
\text { Computacionais } \\
\text { (utilização de } \\
\text { algoritmos por SIG's) }\end{array}$ & $\begin{array}{l}\checkmark \text { O aumento no número de } \\
\text { classes de declividades não } \\
\text { acresce o tempo de } \\
\text { construção da carta. } \\
\checkmark \text { O usuário além de poder } \\
\text { modificar o número de } \\
\text { classes de declividades uma } \\
\text { vez iniciado o processo de } \\
\text { confecção da carta, também } \\
\text { pode construir novas cartas } \\
\text { com outros intervalos de } \\
\text { classes de modo } \\
\text { instantâneo. }\end{array}$ & $\begin{array}{l}\text { Requer um período de tempo } \\
\text { maior na confecção } \\
\text { principalmente na } \\
\text { digitalização da topografia e } \\
\text { definição do melhor MNT. } \\
\text { Depende da experiência do } \\
\text { usuário na construção de um } \\
\text { bom MNT. } \\
\text { O produto final pode não } \\
\text { representar a realidade. }\end{array}$ \\
\hline
\end{tabular}

No passo seguinte promoveutse a conversão do arquivo de desenho vetorial $\begin{array}{lllllll}\text { para } \mathrm{o} \text { formato de planilha (DAT) utilizado o freeware } d x f 2 x y z & 1.3\end{array}$ (www.guthcad.com.au). A partir desse procedimento, os campos que compõem a tabela registram informações relativas a longitude, a latitude e a altitude de cada ponto digitalizado.

O software Surfer 7.00 foi escolhido para geração do MNT, pois este reúne um grande número de algoritmos de interpolação com diversas opções, são eles: Inverso da Potência da Distância (Inverse Distance to a Power), Krigagem (Kriging), Mínima Curvatura (Minimum Curvature), Método Modificado de Shepard (Modified Shepard's Method), Vizinho Natural (Natural Neighbor), Vizinho mais Próximo (Nearest Neighbor), Regressão Polinomial (Polynomial Regression), Função de Base Radial (Radial Basis Fuction) e Triangulação com Interpolação Linear (Triangulation with Linear Interpolation). 


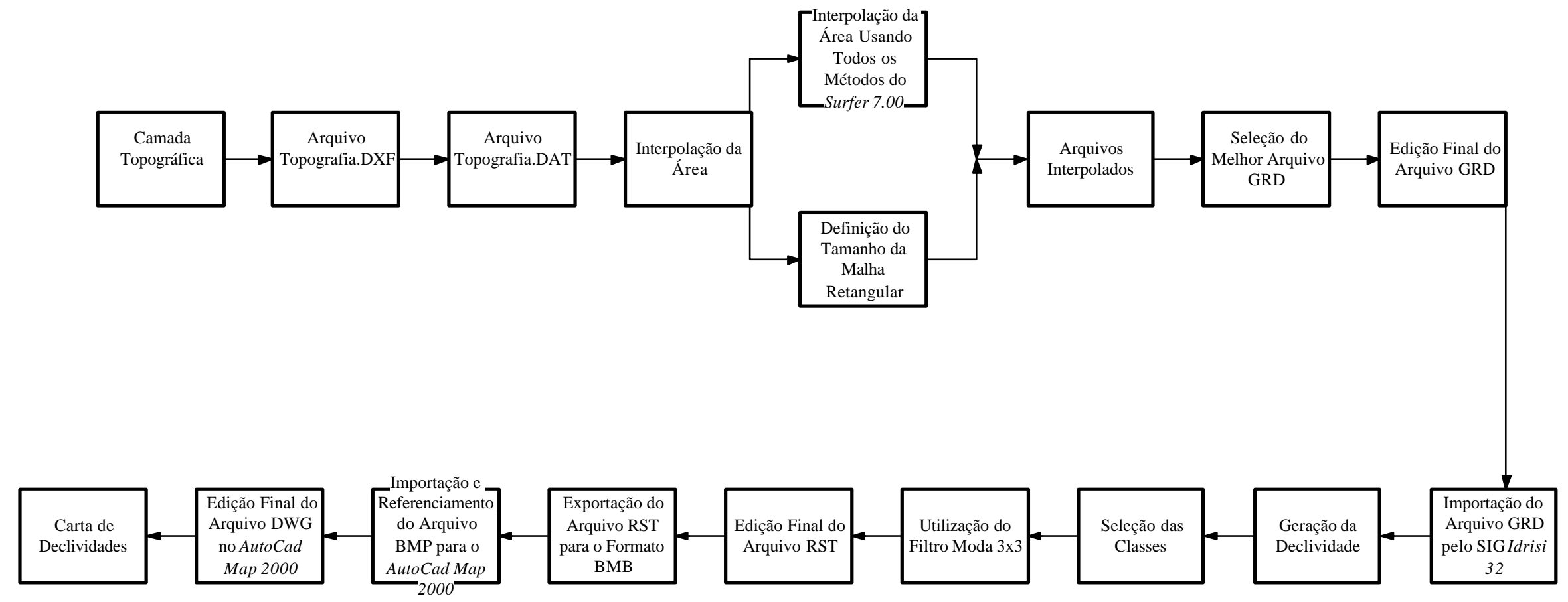

FIGURA - 5.3 Etapas seguidas para construção da Carta de Declividades. 
Todos os métodos foram empregados sempre tomando como base a utilização de um mesmo espaçamento para todos os interpoladores. A malha quadrada foi escolhida de forma a coincidir com a resolução espacial das imagens do LANDSAT 5 (imagens utilizadas na pesquisa) fornecidas pelo seu sensor multiespectral do tipo mapeador temático (thematic mapper). Assim, a distância matricial entre os pontos representa um espaçamento que corresponde na realidade ao valor de $30 \mathrm{~m}$, de maneira a facilitar futuras operações com outros mapas que serão utilizados.

Desde o inicio, optou-se pela interpolação de toda a superfície das quatro cartas topográficas, apesar da área em estudo estar somente inserida de modo parcial em cada uma delas. Tal procedimento, a primeira vista, acarreta acréscimo no tempo de execução de tarefas como digitalização e interpolação, o que se caracteriza como aspecto negativo. Contudo, a experiência do grupo de trabalho de cartografia geotécnica da EESC/USP aponta que o aumento da superfície digitalizada além dos limites da área de interesse melhoram sensivelmente o resultado alcançado na construção dos MNT's. Isso ocorre porque os interpoladores trabalham com malhas retangulares, assim áreas irregulares, se não contarem com uma superfície digitalizada retangular, terão seu MDT afetado nas bordas.

Os primeiros resultados mostraram que interpolações realizadas por krigagem, função de base radial e mínima curvatura forneceram produtos bastante satisfatórios, o que de certa forma já era previsto, pois de acordo com Manual do SURFER \& 7.00 (1999) tais métodos são os melhores quando se trabalha com um grande número de pontos (acima de 30.000).

Apesar desses bons resultados, todos os interpoladores, por conta da ausência de informação topográfica sob a superfície ocupada pelo reservatório da Hidroelétrica de Caconde, causaram modificações significativas nos setores vizinhos ou muito próximos a represa. Desse modo, comprometeram a geração da carta de declividade nessas regiões uma vez que os MNT's não foram fiéis. A solução utilizada para essa situação especial se baseou no emprego de um recurso disponível no programa Surfer ${ }^{\circledR} 7.00$ denominado de faults. 
De acordo com o Manual do SURFER $® 7.00$ (1999) uma falha ou linha de falha é um arquivo bidimensional que define uma linha que age como uma barreira durante o processo de interpolação. Além disso, se tal linha corresponder a um polígono fechado, o algoritmo de interpolação calcula somente os valores dos nós baseados em dados do seu interior, portanto não levando em consideração nem interferindo nos pontos que estão fora.

Desse modo, a linha que delimita o polígono da represa da Hidroelétrica de Caconde foi transformada numa linha de falha, de forma que os valores dos nós internos deveriam ser calculados tomando por base a cota estabelecida de $870 \mathrm{~m}$. Para essa nova etapa foram selecionados os três melhores interpoladores da fase anterior.

A definição do MNT mais adequado se deu a partir da comparação entre as posições das curvas de nível fornecidas pelas cartas topográficas e suas posições redefinidas ao final pelos modelos. Nesse caso, a krigagem ordinária utilizando variograma linear sem efeito pepita apontou o melhor resultado.

A partir desse momento, o arquivo GRD gerado foi editado de forma que seus limites fossem redefinidos (Tabela 5.2). Utilizando o comando: GRID $\rightarrow$ EXTRACT um novo arquivo foi criado onde os novos limites foram situados próximos à área delimitada pelo perímetro da bacia.

A importação bem sucedida dos dados interpolados e editados, além de sua conversão para o formato RST, possibilitaram a geração da declividade com sucesso pelo Idrisi ${ }^{\circledR}$ 32. Assim, através do seu módulo de análise de superfície (surface analysis) o SIG calculou a inclinação do terreno, utilizando valores percentuais, para posição de cada nó.

A definição dos intervalos e a quantidade de classes de declividades seguiram o exemplo bem sucedido do relatório de integração do Instituto Geológico - IG (1993) no estudo do subsídio do meio físico-geológico para o Município de Campinas (SP). 
TABELA 5.2 - Parâmetros geométricos dos arquivos digitalizado e interpolado na construção do MNT.

\begin{tabular}{|c|c|c|c|c|}
\hline ARQUIVO DAT (Digitalizado) & Valor Mínimo & $\begin{array}{c}\text { Valor } \\
\text { Máximo }\end{array}$ & Espaçamento & $\begin{array}{l}\text { Total de } \\
\text { Pontos } \\
\end{array}$ \\
\hline Coordenada Longitudinal (UTM) & 318.675 & 370.966 & - & - \\
\hline Coordenada Latitudinal (UTM) & 7.566 .132 & 7.621 .992 & - & - \\
\hline \multirow[t]{2}{*}{ Posição Altimétrica } & 700 & 1760 & - & - \\
\hline & & & & 467.027 \\
\hline $\begin{array}{c}\text { ARQUIVO GRD (Interpolado } \\
\text { por Krigagem) }\end{array}$ & Valor Mínimo & $\begin{array}{c}\text { Valor } \\
\text { Máximo }\end{array}$ & Espaçamento & Total de Nós \\
\hline Coordenada Longitudinal (UTM) & 318.675 & 370.966 & 30 & - \\
\hline Coordenada Latitudinal (UTM) & 7.566 .132 & 7.621 .992 & 30 & - \\
\hline \multirow[t]{2}{*}{ Posição Altimétrica } & 687,839 & 1763,427 & - & - \\
\hline & & & & 3.249 .072 \\
\hline $\begin{array}{c}\text { ARQUIVO GRD (Interpolado } \\
\text { por Krigagem) EDITADO }\end{array}$ & Valor Mínimo & $\begin{array}{c}\text { Valor } \\
\text { Máximo }\end{array}$ & Espaçamento & Total de Nós \\
\hline Coordenada Longitudinal (UTM) & 323.985 & 360.015 & 30 & - \\
\hline Coordenada Latitudinal (UTM) & 7.579 .992 & 7.616.022 & 30 & - \\
\hline Posição Altimétrica & 732,789 & 1636,119 & - & - \\
\hline & & & & 1.444 .804 \\
\hline
\end{tabular}

Neste estudo o IG propôs intervalos de classes baseados na capacidade do uso do solo levando em consideração aspectos agrícolas, geológicos e geotécnicos, além de resoluções legislativas federais de caráter ambiental como a Lei que Institui o Código Florestal (Lei n 4.471/65) e a Lei que Dispõe sobre o Parcelamento do Solo Urbano (Lei no 6.766/79). As classes de declividades escolhidas (Tabela 5.3), bem como as recomendações de uso e as restrições e/ou problemas esperados estão presentes no ANEXO II. 
TABELA 5.3 - Resultados da distribuição das classes na Carta de Declividades após a utilização do filtro moda $(3 \times 3)$.

\begin{tabular}{|c|c|c|}
\hline Classe de Declividade & $\begin{array}{l}\text { Total de Área Ocupada } \\
\text { em } \mathbf{k m}^{\mathbf{2}}\end{array}$ & $\begin{array}{l}\text { Percentual da Área } \\
\text { Ocupada }\end{array}$ \\
\hline$<2 \%$ & 9,35 & 1,94 \\
\hline 2 a 5 \% & 42,71 & 8,86 \\
\hline 5 a 10 \% & 77,25 & 16,02 \\
\hline 10 a 15\% & 71,27 & 14,78 \\
\hline 15 a 20 \% & 67,9 & 14,08 \\
\hline 20 a 25 \% & 58,94 & 12,22 \\
\hline 25 a 30 \% & 41,28 & 8,56 \\
\hline 30 a 47 \% & 99,71 & 20,67 \\
\hline > 47 \% & 13,89 & 2,88 \\
\hline TOTAL & 482,31 & 100,00 \\
\hline
\end{tabular}

A última etapa seguida para se obter o melhor produto para carta de declividades foi a utilização do filtro moda $(3 \times 3)$ por meio do módulo de filtragem digital (digital filtering) do Idrisi ${ }^{\circledR} 32$ (comando: ANALYSIS $\rightarrow$ CONTEXT OPERATOR $\rightarrow$ FILTER). Tal procedimento, como simplificado na figura 5.4, redefiniu os pixels anteriormente presentes de forma a diminuir os resíduos, tornando assim, os intervalos de declividades mais homogêneos (Figura 5.5).

A conversão do formato RST para o BMP por parte do Idrisi ${ }^{\circledR} 32$ permitiu que esse arquivo raster fosse reconhecido pelo AutoCad Map 2000, possibilitando assim, a sua edição final com o mesmo formato dos outros mapas e cartas em anexo nessa dissertação (arquivo DWG).

\subsubsection{Mapa de Substrato Rochoso}

O mapa de substrato rochoso (ANEXO III) representa a disposição espacial das rochas que compõem as unidades litológicas do Maciço Alcalino de Poços de Caldas e do Complexo Varginha (Figura 5.6). 


\begin{tabular}{|l|l|l|}
\hline 3 & 3 & 3 \\
\hline 0 & 4 & 0 \\
\hline 3 & 3 & 3 \\
\hline
\end{tabular}
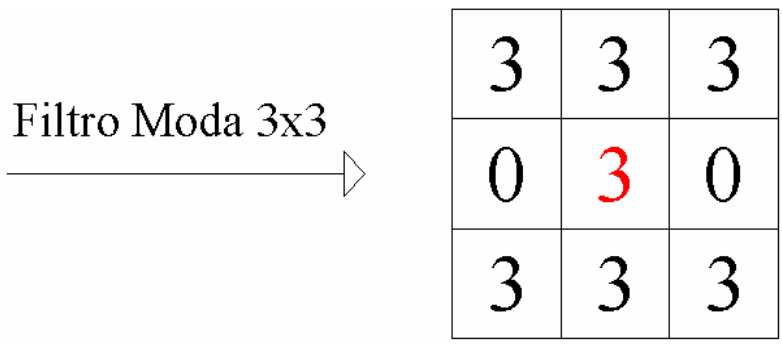

FIGURA 5.4 - Utilização do filtro moda numa porção do MDT onde o grid é 3x3. Observe que o valor do pixel central da malha situada a esquerda é igual a 4, porém após a utilização do filtro o valor é redefinido a partir da moda (valor que mais se repete).

O mapa produzido não traz, e nem sugere, modificações na coluna estratigráfica proposta pela literatura geológica para área em estudo. Contudo, o mapa gerado visa contribuir com o conhecimento geológico-geotécnico da região uma vez que redefine contatos geológicos estabelecidos por estudos anteriores, além de promover o mapeamento de setores que não dispunham de informação geológica em escala compatível.

Os procedimentos seguidos para construção do mapa de substrato rochoso são os mesmos utilizados na confecção de mapas geológicos. O passo inicial foi a realização de uma revisão de literatura com o objetivo de se conhecer a distribuição e as características geológicas das principais unidades litoestratigráficas presentes na área estudada.

Ainda nessa fase inicial, buscou-se colecionar dados geológicos principalmente na forma de mapas (em escalas compatíveis) além de informações geológicas pontuais que pudessem auxiliar a fotointerpretação, esta realizada a partir de trinta e três fotografias aéreas convencionais da FAB/USAF obtidas por meio de vôos realizados entre 1964 e 1966, executados com escala aproximada de 1:60.000.

Desse modo, ficou estabelecido que o mapa de substrato rochoso se basearia numa divisão mais simplificada de unidades litológicas pré-cambrianas do Complexo Varginha definidas por Oliveira et al. (1983) e unidades mesozóicas do Complexo Alcalino de Poços de Caldas mapeadas por Liporaci (1994). 

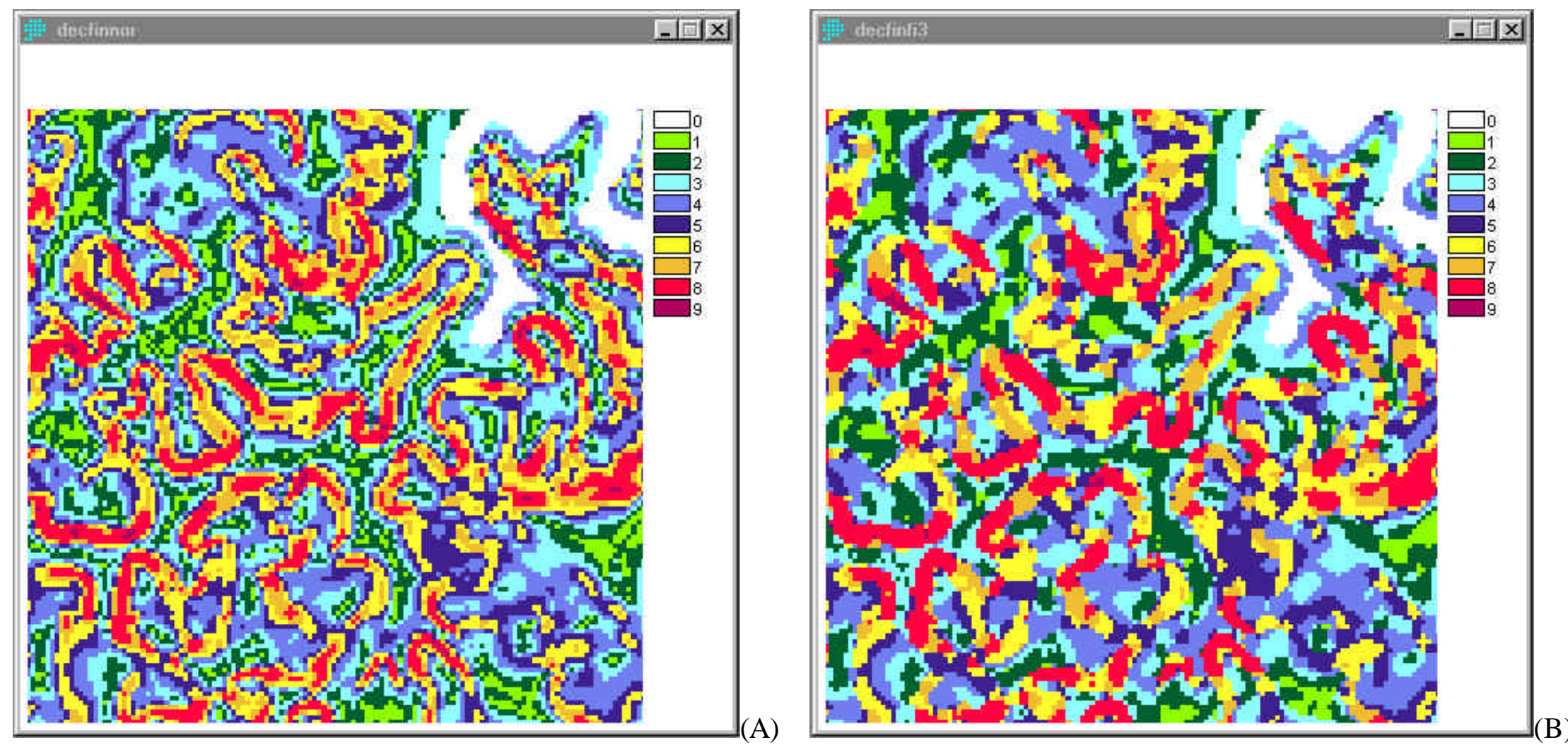

FIGURA 5.5 - Aspecto da declividade antes da utilização do filtro moda (3x3) à esquerda (A) e depois à direita (B). As classes representadas pela legenda de cores são: 0 (Reservatório da Hidroelétrica de Caconde), 1 (<2\%), 2 (2 a $5 \%$ ), 3 (5 a 10 $\%), 4(10$ a $15 \%), 5(15$ a $20 \%), 6(20$ a $25 \%), 7$ (25 a $30 \%), 8$ (30 a $47 \%)$ e 9 (> $47 \%)$. 


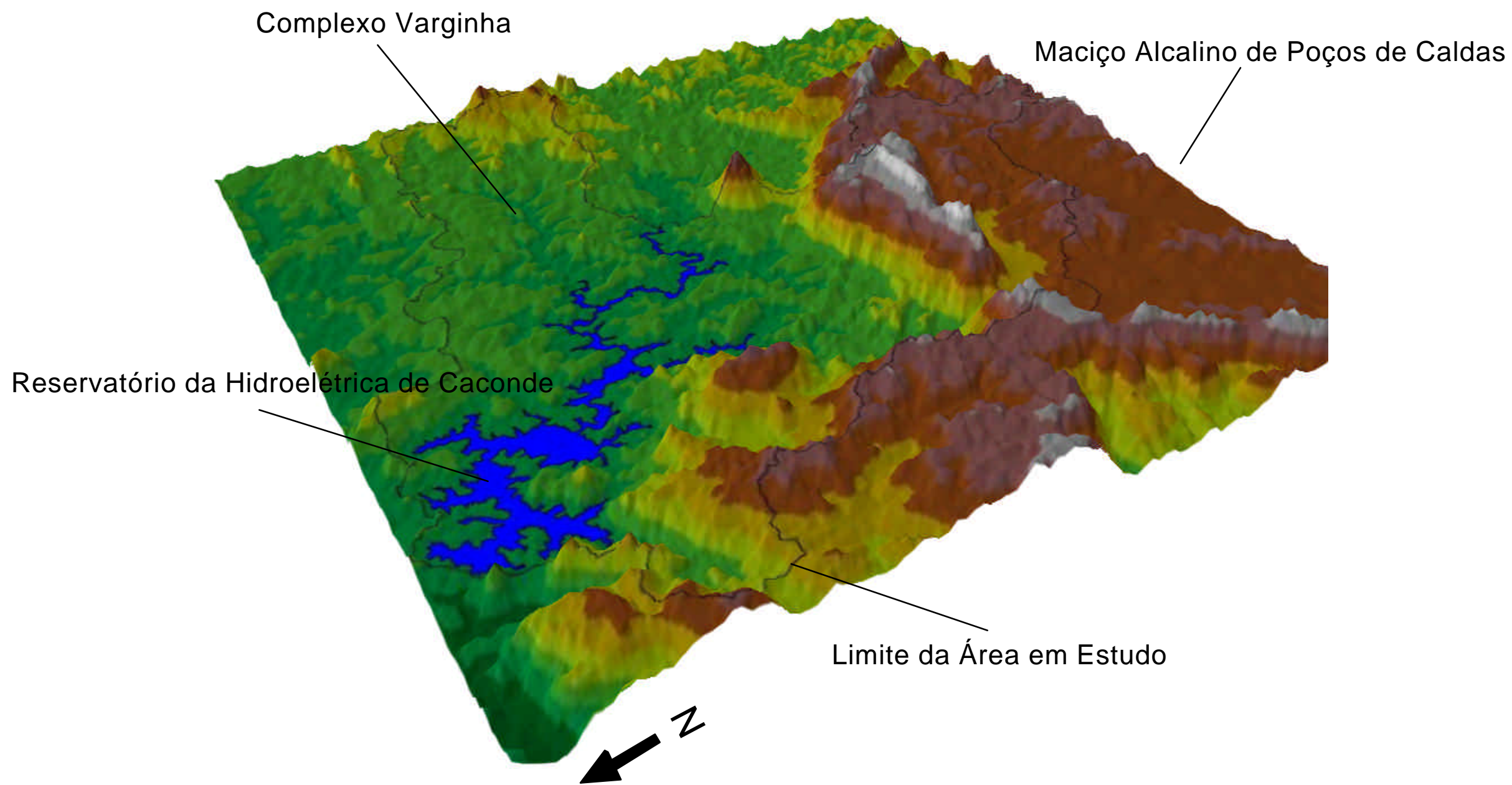

FIGURA 5.6 - Modelo digital de terreno indicando o posicionamento espacial do Maciço Alcalino (estrutura circular) e do Complexo Varginha (relevo mais arrasado) gerado a partir do software ArcView® 3.1. 
As informações geológicas pontuais foram obtidas por meio da consulta ao banco de dados da CPRM chamado de MICROSIR. Tal sistema disponibiliza aos usuários informações acerca de afloramentos geológicos, análises geoquímicas, ocorrências minerais e poços para água subterrânea baseados nos trabalhos desenvolvidos pela CPRM desde sua criação em todo o território nacional.

Especificamente para a área em estudo, os dados preexistentes recuperados referem-se somente as fichas de campo utilizadas por Cavalcante et al. (1979). Nessas são apresentadas informações relativas à localização, ao relevo, à vegetação, aos solos, à descrição geológica e à classificação estratigráfica.

Os trabalhos de fotointerpretação e de campo foram fundamentais na etapa seguinte de definição do mapa de substrato rochoso. A partir dessa fase, foi possível checar as características geológicas e a distribuição espacial das unidades litológicas definidas pelos autores anteriormente citados ao longo da área em estudo.

Desta forma foram comparados no campo os resultados apresentados pelo mapa base (produto da fotointerpretação) e o mapa geológico compilado, de forma que, unidades anteriormente mapeadas tiveram redefinidas tanto litologias associadas quanto seus contatos geológicos.

A determinação das unidades que compõem o mapa de substrato rochoso ocorreu ao final de três campanhas de campo, antecedidas e sucedidas de trabalhos de fotointerpretação geológica. As unidades mapeadas são descritas a seguir.

\section{COMPLEXO VARGINHA}

\section{Migmatitos Graníticos e Estromatíticos}

Migmatitos graníticos e migmatitos estromatíticos de acordo com Oliveira et. al. (1983) formam unidades distintas do Complexo Varginha presentes na área em estudo. Essas unidades litológicas foram agrupadas por diversas razões, a primeira delas é que os contatos geológicos estabelecidos para o mapa base e o mapa compilado se mostravam muito diferentes, mesmo com o avanço do conhecimento da área através de sucessivas visitas ao campo e reinterpretação de fotografias aéreas.

Além disso, o complexo padrão de migmatização, associado a escassez de afloramento de rocha sã dos dois litotipos, prejudicaram suas identificações e diferenciações, desse modo, optou-se pela junção das duas unidades. 
Os migmatitos graníticos são formados pelo conjunto de tipos petrográficos ricos em leocossoma que apresentam estruturas bandadas, nebulíticas e schliren. São rochas leococráticas e mesocráticas, de coloração rósea e branca e às vezes cinza escuro a preto. Apresentam atitudes predominantemente NW com mergulhos suaves a fortes para SW. Do ponto de vista estrutural, tais rochas exibem padrões de dobramentos complexos. O bandamento e a foliação cataclástica de modo geral estão presentes.

Os migmatitos estromatíticos compreendem tipos petrográficos com predominância de paleossoma formado de hornblenda gnaisse, anfibolitos e granulitos que apresentam estrutura predominantemente bandada. Os migmatitos estromatíticos afloram na área de duas maneiras, a primeira sob a forma de afloramentos isolados (quase sempre a rocha está semi-alterada), o segundo modo, que é o tipo mais comum, na forma de leitos e núcleos intercalados nos migmatitos graníticos (Figura 5.7). A foliação predominante observada nessa rochas é a cataclástica.

Os migmatitos graníticos e estromatíticos desenvolvem-se por todo Complexo Varginha. Constituem-se na maior unidade do substrato rochoso mapeada ocupando $234,05 \mathrm{~km}^{2}(48,53 \%$ do total).

\section{Granulitos Quartzo-Feldspáticos}

Granulitos são rochas predominantemente compostas de feldspato, contudo essa unidade recebeu tal denominação por se constituir essencialmente de quartzo e feldspato podendo conter ou não uma pequena parcela de máficos.

São rochas leucocráticas e hololeucocráticas que apresentam atitudes com direções preferenciais NW e mergulho SW. Exibem granulação média podendo às vezes apresentar grãos mais grossos e são caracterizados por acentuado desenvolvimento de foliação cataclástica.

Os granulitos quartzo-feldspáticos se entendem pela área em estudo por uma longa faixa NE - SW ocupando $66,54 \mathrm{~km}^{2}$ (13,80\% do total). 


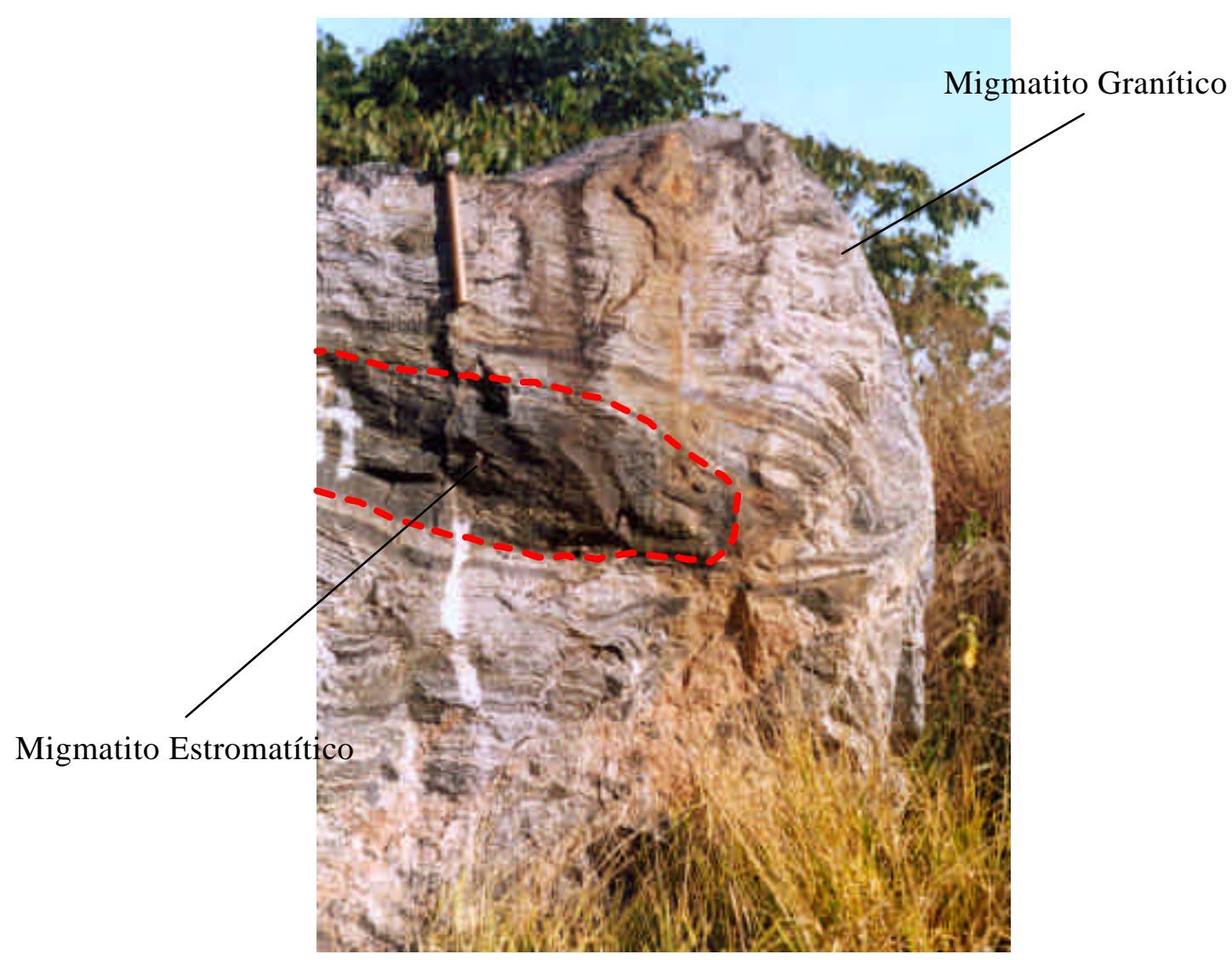

FIGURA 5.7 - Migmatitos estromatíticos formando leitos intercalados nos migmatitos graníticos.

\section{Charnockitos}

Os charnockitos mapeados se apresentam bastante alterados, onde afloramentos de rocha sã ou semi-alterada são muito restritos. Nesses casos, pode-se observar rochas de coloração predominantemente verde escura, estruturas gnáissicas e granulação que varia de fina a média, podendo mesmo chegar a grossa. Os charnockitos se estendem por uma superfície de $77,65 \mathrm{~km}^{2}$ (16,10\% do total) e ocupam a porção central da área estudada.

\section{Migmatitos Oftalmíticos}

Os migmatitos oftalmíticos constituem a menor unidade mapeada para o substrato rochoso com apenas $5,22 \mathrm{~km}^{2}$ (1,08\% do total). Esse grupo é formado por rochas migmatíticas facilmente identificadas no campo por uma série de características. 
A principal delas é riqueza de porfiroblastos de $\mathrm{k}$-feldspato, centimétricos, alongados e alinhados paralelamente a foliação. Além dessas qualidades, pode-se observar a predominância do neossoma sobre o paleossoma, granulação grossa e a presença de estruturas maciças ou bandadas.

A unidade do substrato rochoso composta por migmatitos oftalmíticos somente aflora na porção NW da área em estudo, onde se mostrou constituída como um corpo isolado bem definido, tanto nos trabalhos de campo, quanto nos de fotointerpretação.

\section{MACICO ALCALINO DE POCOS DE CALDAS}

\section{Fonólitos e Tinguaítos}

Fonólitos e tinguaítos predominam nas porções norte e oeste do maciço alcalino e ocupam $47,30 \mathrm{~km}^{2}(9,81 \%$ do total). Na maioria dos locais onde afloram o relevo é acidentado, formado principalmente por escarpas com altas declividades (unidades D02 e D03 do Mapa de Landforms).

Tais litotipos, quando vistos em fotografias aéreas, são facilmente reconhecidos pelas grandes estruturas circulares que formam e que constituem a borda do maciço. Além dessas estruturas, fonólitos e tinguaítos estão presentes em outros setores representados por colinas de topos arredondados na forma aproximada de meia laranja.

Fonólitos e tinguaítos exibem coloração cinza esverdeado a preto e texturas que variam de afanítica a fanerítica fina ou mediamente fina. Do ponto de vista químico e mineralógico são muito semelhantes, sendo na maioria das vezes distinguíveis em função do tamanho dos seus minerais constituintes.

Os fonólitos possuem granulação muito fina, chegando as vezes a expor porções vítreas, por outro lado os tinguaítos apresentam uma granulação mais grossa o que permite o reconhecimento dos seus minerais a olho nu em alguns afloramentos. 
A estrutura presente nessas rochas é maciça, porém, por conta do resfriamento durante o processo de solidificação, formaram-se planos de fraqueza verticais e subverticais (Figura 5.8). Além disso sistema de juntas com direções preferenciais NE-SW foram estruturalmente impostos a posterior. Assim, esses materiais geológicos afloram formando blocos aproximadamente retangulares de tamanhos que variam de $0,15 \mathrm{~m}$ a até mais de $2,5 \mathrm{~m}$.

\section{Nefelina Sienitos}

Nefelina sienitos apresentam composição química e mineralógica muito próximas aos 6nólitos e tinguaítos. Diferenciam-se pelo modo de ocorrência na crosta. Os primeiros possuem natureza plutônica enquanto que fonólitos e tinguaítos vulcânicas e subvulcânicas respectivamente.

As rochas dessa unidade são de cor cinza com tonalidades esverdeadas e estrutura maciça (Figura 5.8). São leococráticas e exibem grandes cristais, em geral idiomorfos, quase que exclusivamente formados por feldspato potássico e nefelina.

Nefelina sienitos afloram na porção sul da área em estudo estendendo-se por uma superfície de $51,53 \mathrm{~km}^{2}$ (10,69\% do total).

As etapas finais de confecção do mapa de substrato rochoso (Figura 5.9) concentram-se no escaneamento das unidades (com restituição das fotografias aéreas através do aerosketchmaster feita preliminarmente), assim como o seu referenciamento, digitalização e edição final no AutoCad Map® 2000.

\subsubsection{Mapa de Materiais Inconsolidados}

O mapa de materiais inconsolidados (ANEXO IV) é documento cartográfico imprescindível e indispensável para o estudo de uma área do ponto de vista geotécnico.

O mapa de materiais inconsolidados representa os materiais geológicos naturais que estão sobre o substrato rochoso são ou pouco alterado. Assim, dependendo do seu grau de refinamento, esse produto cartográfico pode auxiliar o usuário a avaliar o comportamento geotécnico desses materiais naturais frente diversas solicitações. 

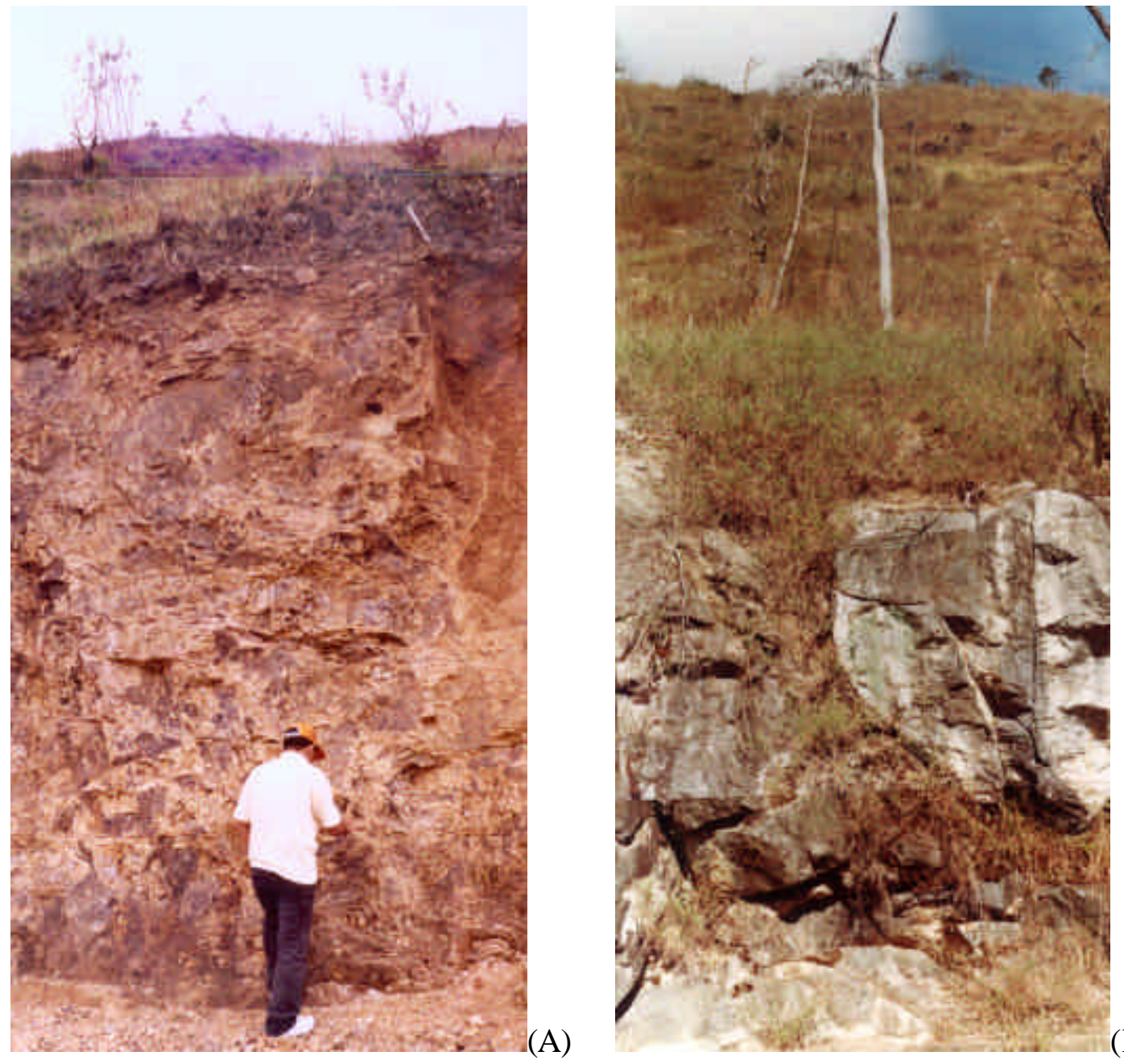

(B)

FIGURA 5.8 - (A) fonólitos e (B) nefelina sienitos, unidades do Maciço Alcalino que compõem o substrato rochoso da área estudada.

Os trabalhos de construção do mapa de materiais inconsolidados (Figura 5.10) se iniciam a partir de fotointerpretação. Portanto, observando principalmente aspectos de textura, padrão e densidade da rede hidrográfica nas fotografias aéreas, determinou-se unidades preliminares de materiais.

Durante a fase de campo os setores anteriormente mapeados foram amostrados e submetidos a ensaios laboratoriais. Dessa maneira, pôde-se redefinir ou refinar suas análises a medida que os novos dados foram adquiridos, além disso, permitiu também selecionar e reorientar áreas para amostragem em etapas seguintes de trabalhos de campo. 


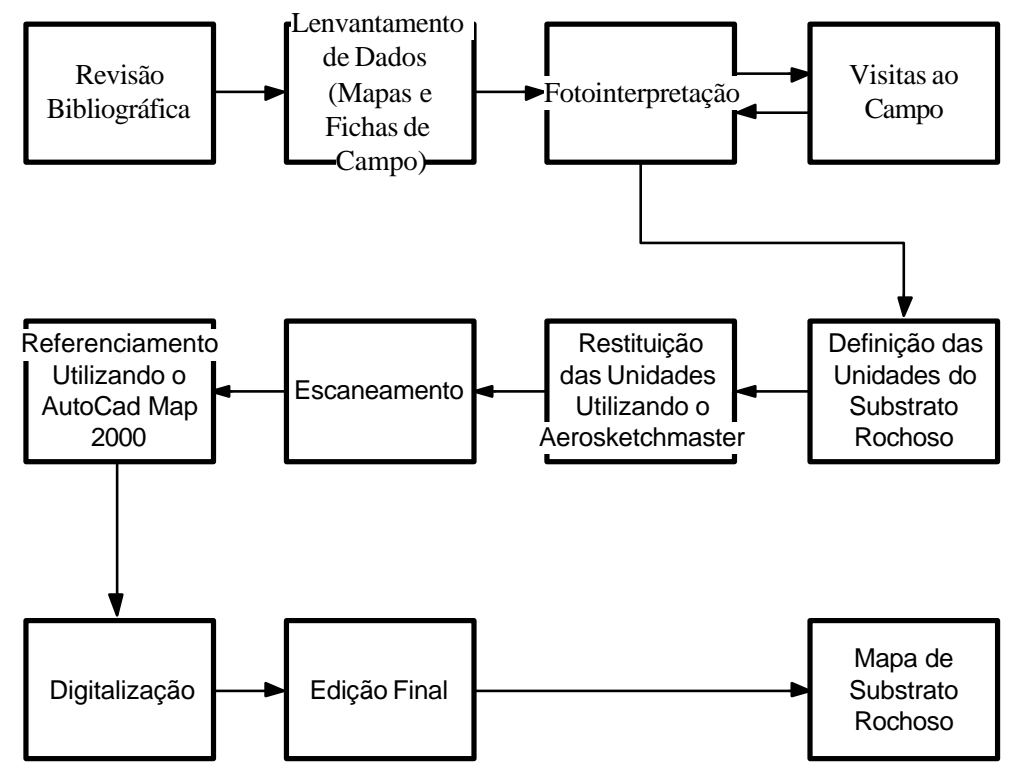

FIGURA 5.9 - Etapas seguidas para a construção do Mapa de Substrato Rochoso.

Além dos ensaios de granulometria conjunta, os materiais inconsolidados também foram caracterizados a partir do ensaio de azul de metileno em função de sua capacidade de troca catiônica (CTC) total, capacidade de troca catiônica (CTC) da fração argila, superfície específica (SE) total, valor de adsorção de azul de metileno para os solos ( $\mathrm{Vb}$ ), valor de adsorção de azul de metileno para a fração argila dos solos (Acb) além da inferência do comportamento laterítico (Figura 5.11), da atividade das argilas (Figura 5.12) de acordo com Pejon (1992) e do potencial expansivo (Pejon, 2000) conforme mostra a Figura 5.13.

Valores de massa específica dos sólidos $\left(\rho_{\mathrm{s}}\right)$ foram determinados para todos os pontos amostrados. Nos locais onde houve a coleta de amostras indeformadas foram obtidos outros índices físicos como massa específica seca $\varrho_{d}$ ), índice de vazios (e), porosidade (n) e grau de saturação $\left(S_{r}\right)$.

Especificamente para área estudada os materiais inconsolidados foram classificados em função de sua origem, textura e intervalo de espessuras predominantes.

Com relação a origem, os materiais inconsolidados de natureza residual foram divididos de acordo com as unidades do substrato rochoso a qual estão associados. Contudo, uma vez verificada a presença de materiais de origem não residual, estes foram designados simplesmente como materiais retrabalhados. 


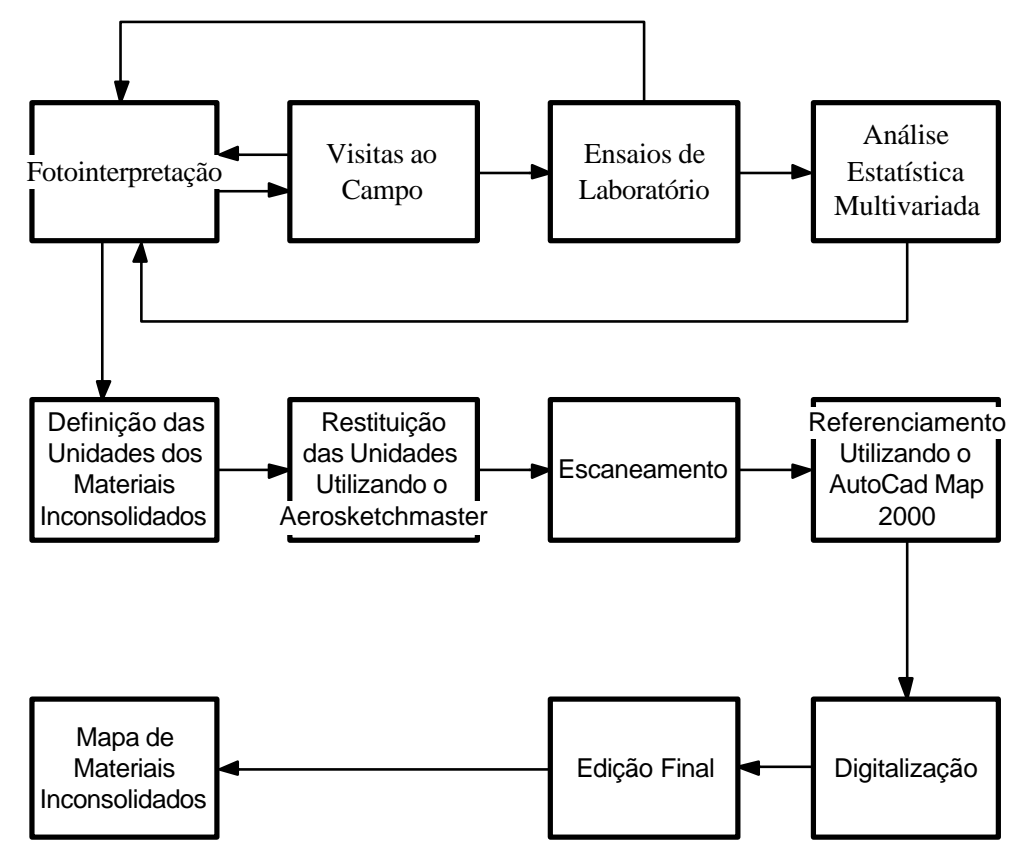

FIGURA 5.10 - Etapas seguidas para a construção do Mapa de Materiais Inconsolidados.

Quanto a classificação das espessuras dos materiais inconsolidados presentes na área em estudo, estes foram divididos em intervalos nos quais se observou que eram os mais freqüentes, são eles: menor que $0,5 \mathrm{~m}$ variando entre 0,5 e 1,5 m, variando entre 1,5 e 3,0 $\mathrm{m}$ e maior que $3,0 \mathrm{~m}$.

Com relação a textura, a subdivisão desses materiais se tornou mais complexa, isso porque ao se estabelecer uma separação baseando-se somente na análise visual das formas das curvas granulométricas ou ainda em percentuais de argila, silte e areia adotados em outros trabalhos, tal divisão poderia não ser adequada para área, ou pior, uma vez implementada não representaria áreas distinguíveis e delimitáveis nas fotografias aéreas.

Desse modo, optou-se pelo desenvolvimento de uma classificação textural dos materiais inconsolidados que atendesse três exigências.

A primeira delas é que a subdivisão somente deveria levar em conta as características próprias das curvas granulométricas produzidas, portanto assumindo o contexto geológico local. Assim, classificações realizadas em outros trabalhos para condições geológicas peculiares não foram consideradas. 


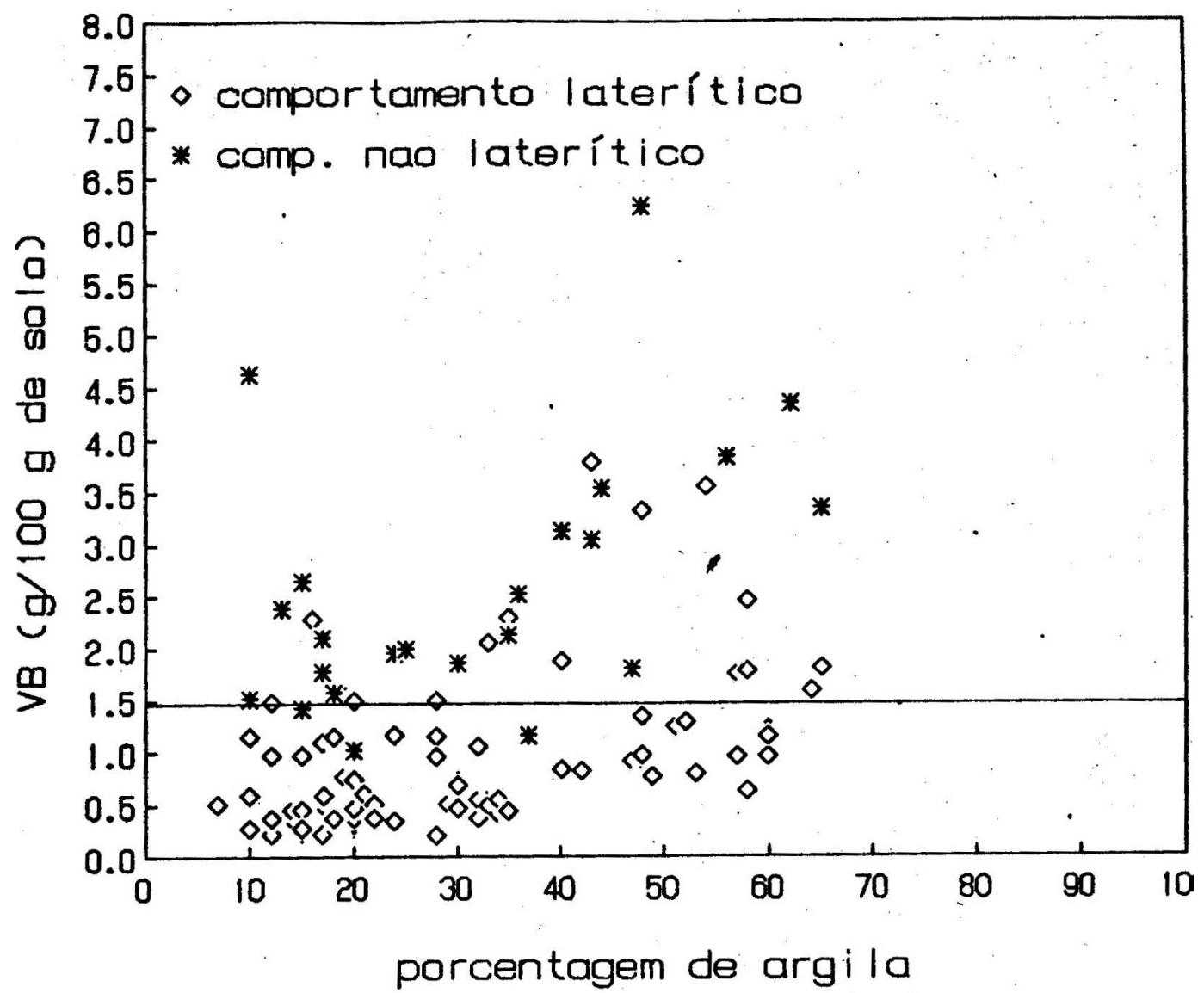

FIGURA 5.11 - Adsorção de azul de metileno em função da porcentagem de argila dos materiais inconsolidados, mostrando o comportamento laterítico ou não laterítico, obtido com a classificação M.C.T. (Fonte: Pejon, 1992).

Em segundo lugar, o critério ou os critérios definidos para essa classificação deveriam ser facilmente compreendidos, de forma que a divisão obtida pudesse rapidamente ser produzida e avaliada pelo usuário.

A terceira condição, e a mais importante, prevê que, uma vez superadas as etapas anteriores, os grupos texturais de materiais inconsolidados representariam áreas distinguíveis e delimitáveis, portanto áreas mapeáveis.

Baseado nessas condições, optou-se pela utilização da análise estatística multivariada ou multidimensional como técnica para definição de uma classificação textural para materiais inconsolidados. 


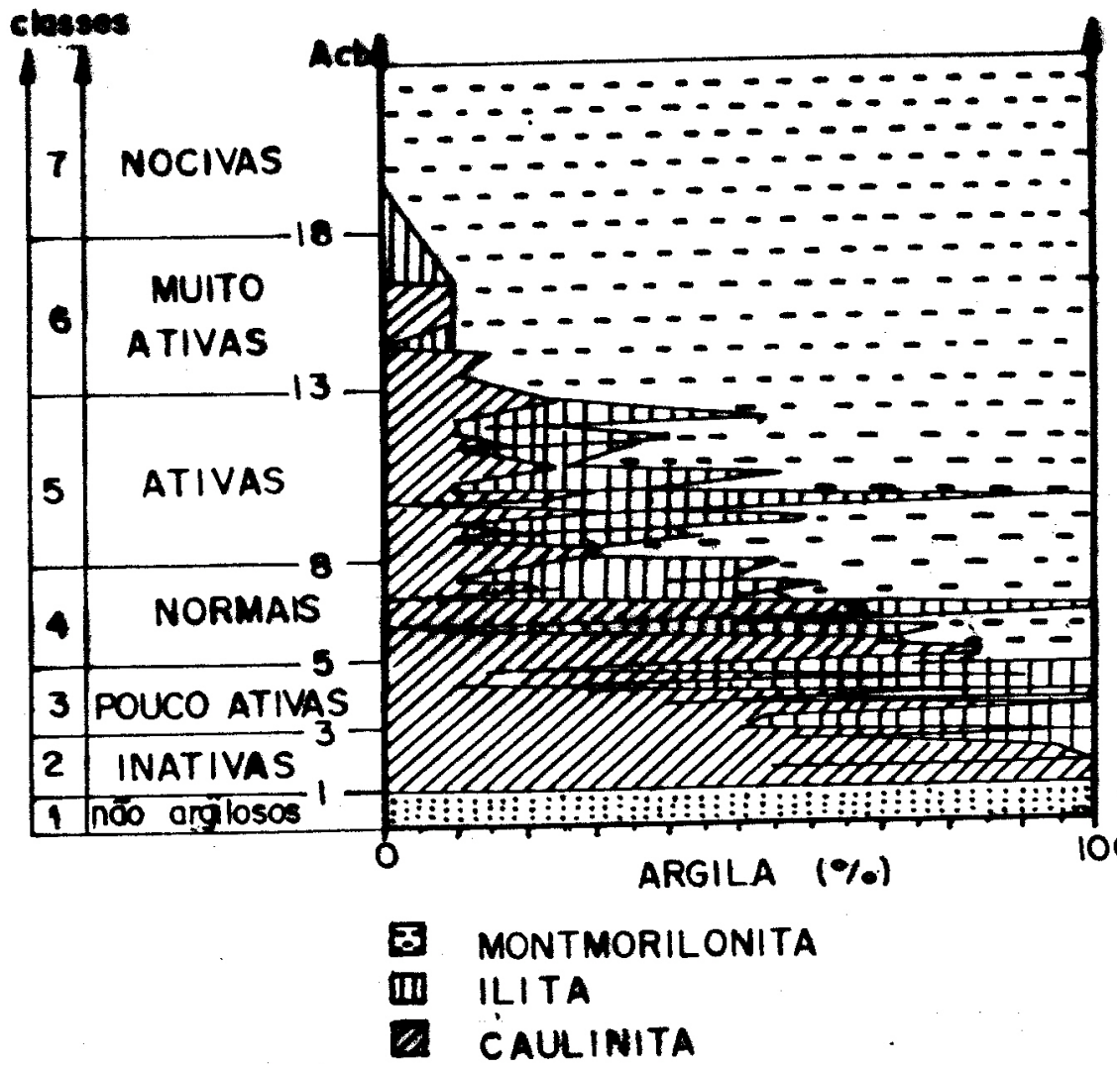

FIGURA 5.12 - Diagrama de atividade das argilas pelo método do azul de metileno (Fonte: Pejon, 1992).

De acordo com Landim (2001) diferentemente da estatística univariada a multivariada consegue detectar as relações entre um conjunto de dados e suas variáveis de forma conjunta, tendo como condição fundamental a igualdade de importância entre as variáveis.

Dentre os diferentes tipos de técnicas classificatórias, a análise de agrupamentos hierárquicos foi escolhida, pois de acordo com o autor esta deve ser utilizada quando se deseja explorar a similaridade entre indivíduos (modo Q).

Segundo Landim (2001) a aplicação da metodologia utilizada para a formação de agrupamentos hierárquicos, relativa a análise de dados geológicos multivariados, demostra que a técnica de agrupamento pareado igualmente ponderado é superior as demais. 


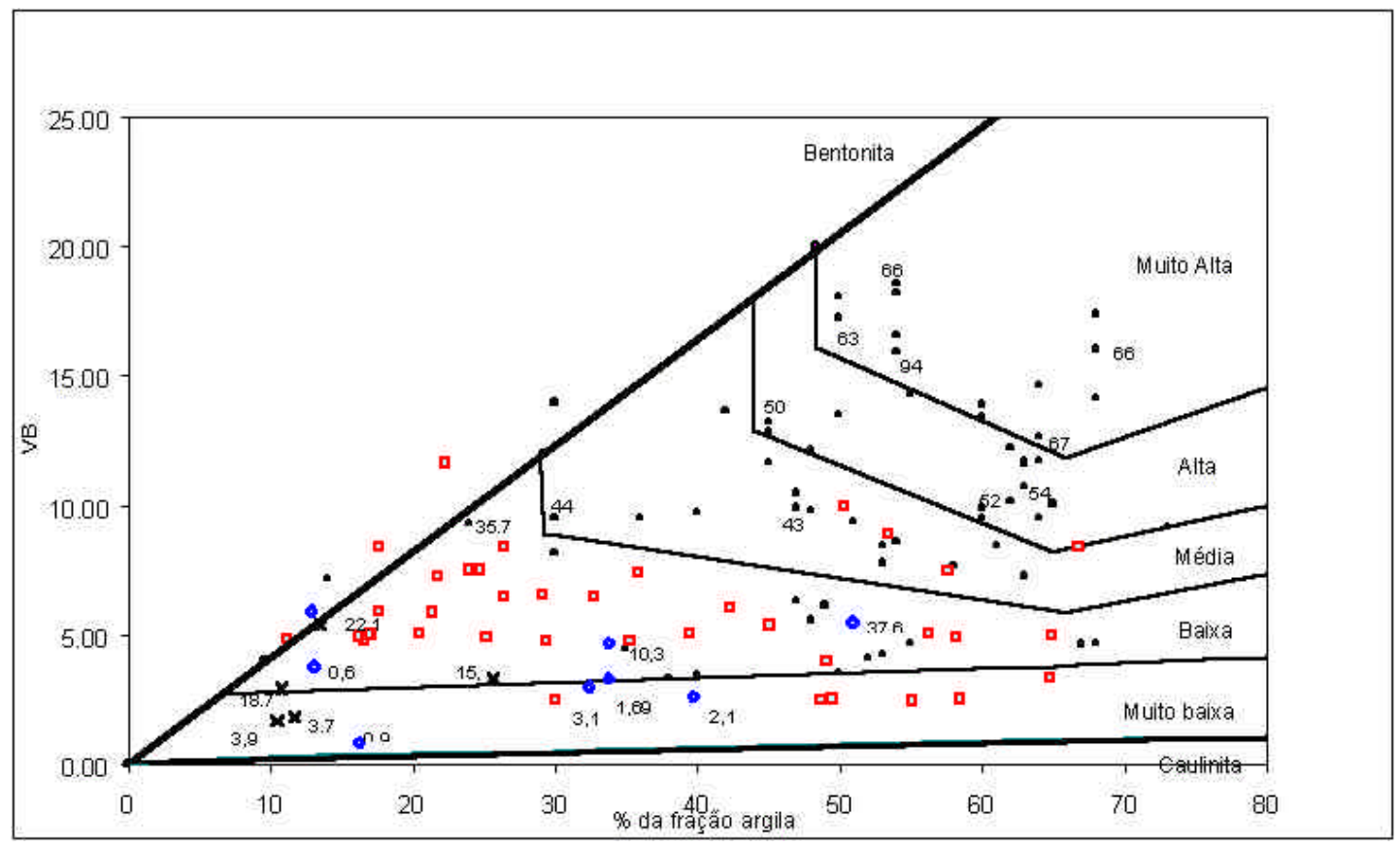

FIGURA 5.13 - Ábaco para determinação do potencial expansivo (Fonte: Pejon, 2000).

Assim, utilizando o software STATISTICA® 5.5, foram analisadas as variáveis que correspondem aos percentuais de argila, silte e areia dos materiais inconsolidados, por meio da técnica de agrupamento pareado igualmente ponderado, empregando a medida de distância euclidiana.

Foram submetidas à análise multivariada os resultados de análise granulométrica de 52 das 59 amostras coletadas de materiais inconsolidados. O restante não foi utilizado, pois correspondem a uma amostragem repetida realizada para alguns perfis, de forma que para cada um deles, foi escolhida somente a amostra mais representativa.

Observando o dendograma produzido (Figura 5.14), nota-se que existe uma ampla possibilidade de agrupamentos, variando desde 50, quando a distância euclidiana é igual a zero, a até dois grupos quando a distância vale 31 .

Os resultados demostraram que com uma distância euclidiana igual a 20 todos os setores podem ser delimitados em fotografias aéreas na escala 1:60.000, exceto o ocupado pela amostra P007-A02 que apresenta dimensões muito pequenas, dificultando desse modo seu mapeamento em função da escala adotada. 


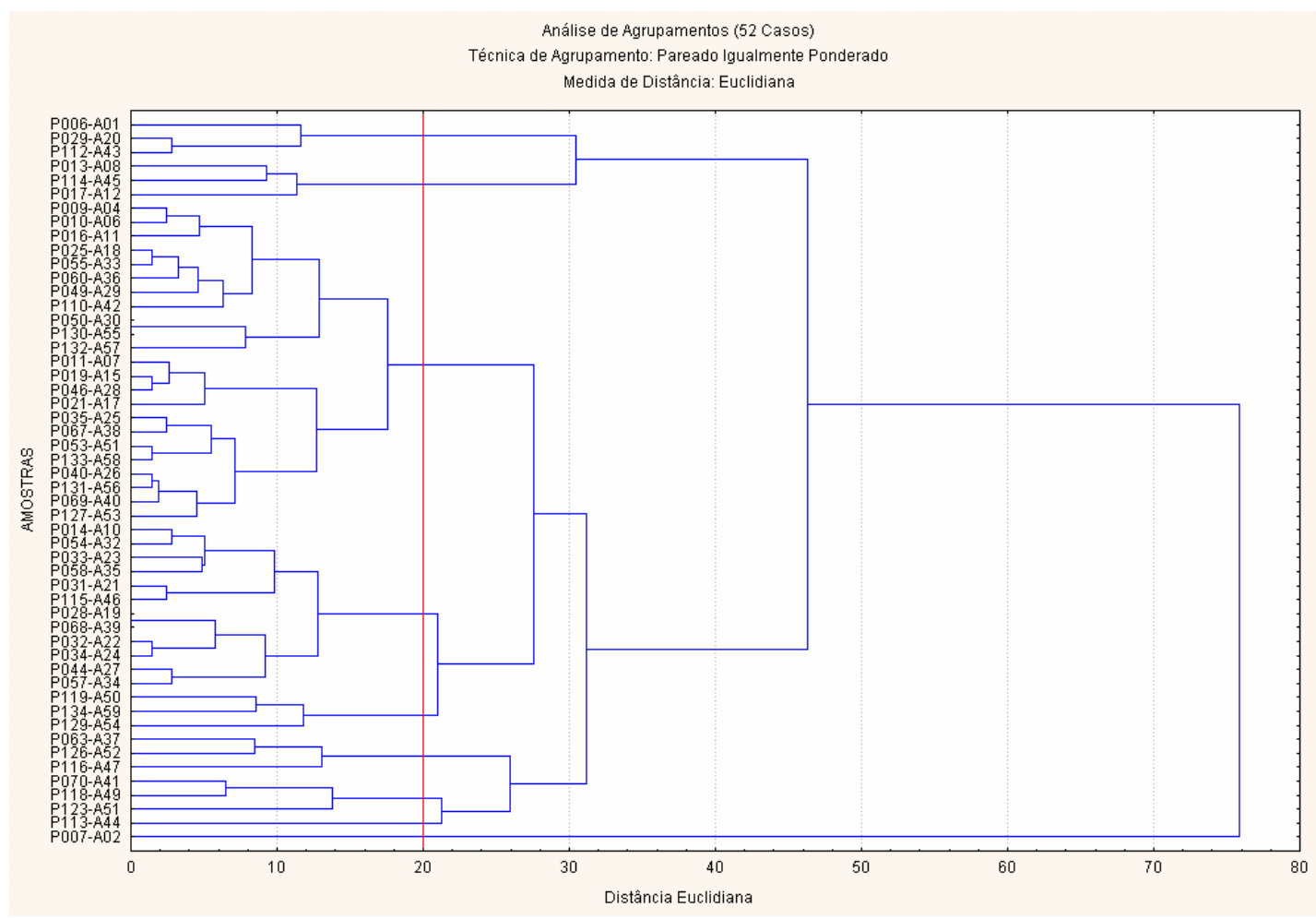

FIGURA 5.14 - Análise de agrupamentos entre as amostras de materiais inconsolidados (modo Q) a partir dos resultados dos ensaios de granulometria conjunta.

A amostra P007-A02 (composta por $3 \%$ de argila, $4 \%$ de silte e $93 \%$ de areia) foi extraída em uma mina a céu aberto onde são explorados arenitos finos e médios e siltitos, que de acordo com Björnberg (1956 e 1959) apud Liporaci (1994), correspondem a arenitos eólicos e intercalações secundárias de siltitos, correlacionadas à Formação Botucatu da Bacia do Paraná.

Os grupos texturais obtidos formam padrões de curvas granulométricas bem definidos (Figuras 5.15 e 5.16). As unidades de materiais inconsolidados são descritas a seguir. 

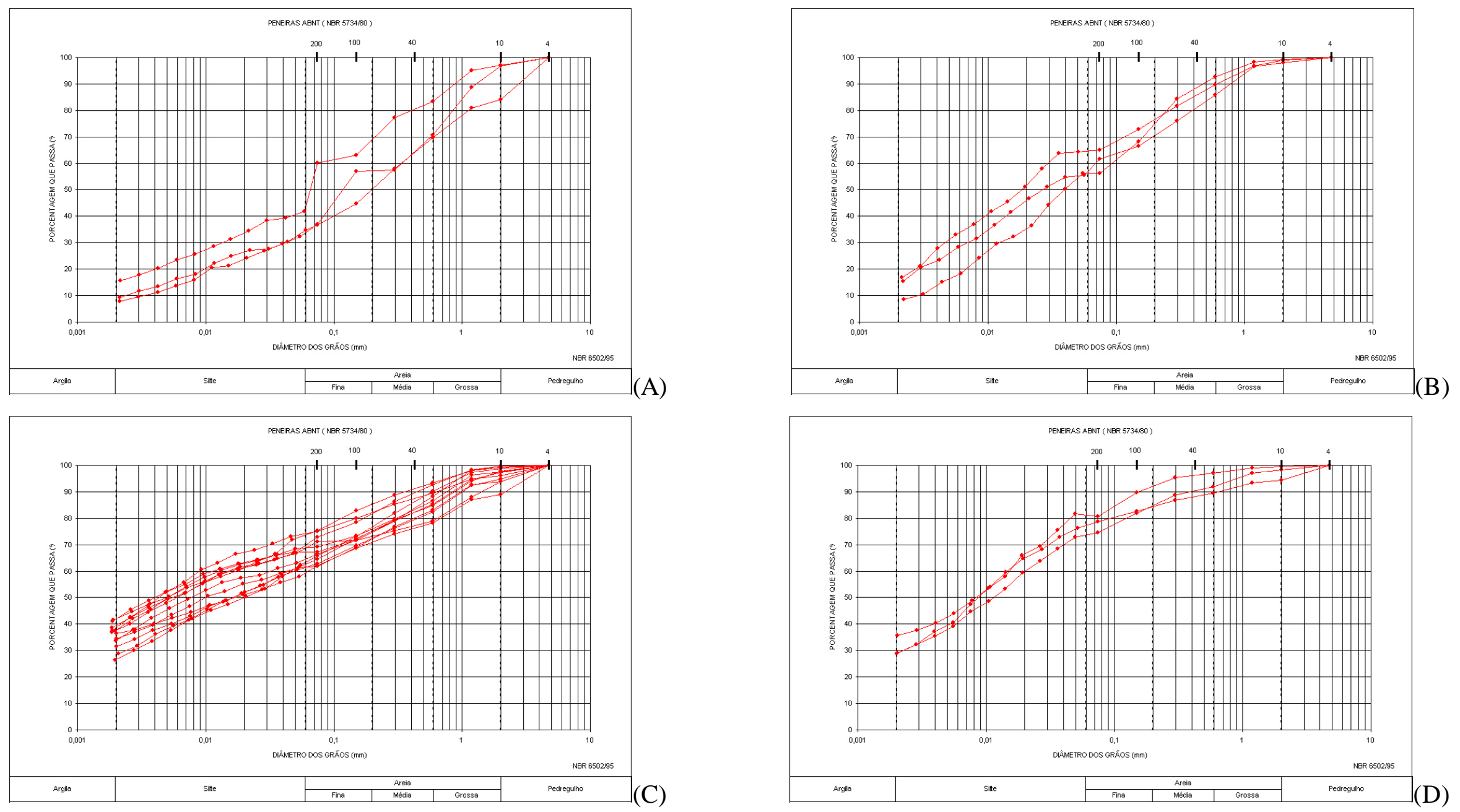

FIGURA 5.15 - Curvas granulométricas das amostras pertencentes aos grupos texturais I (A), II (B), III (C) e IV (D). 

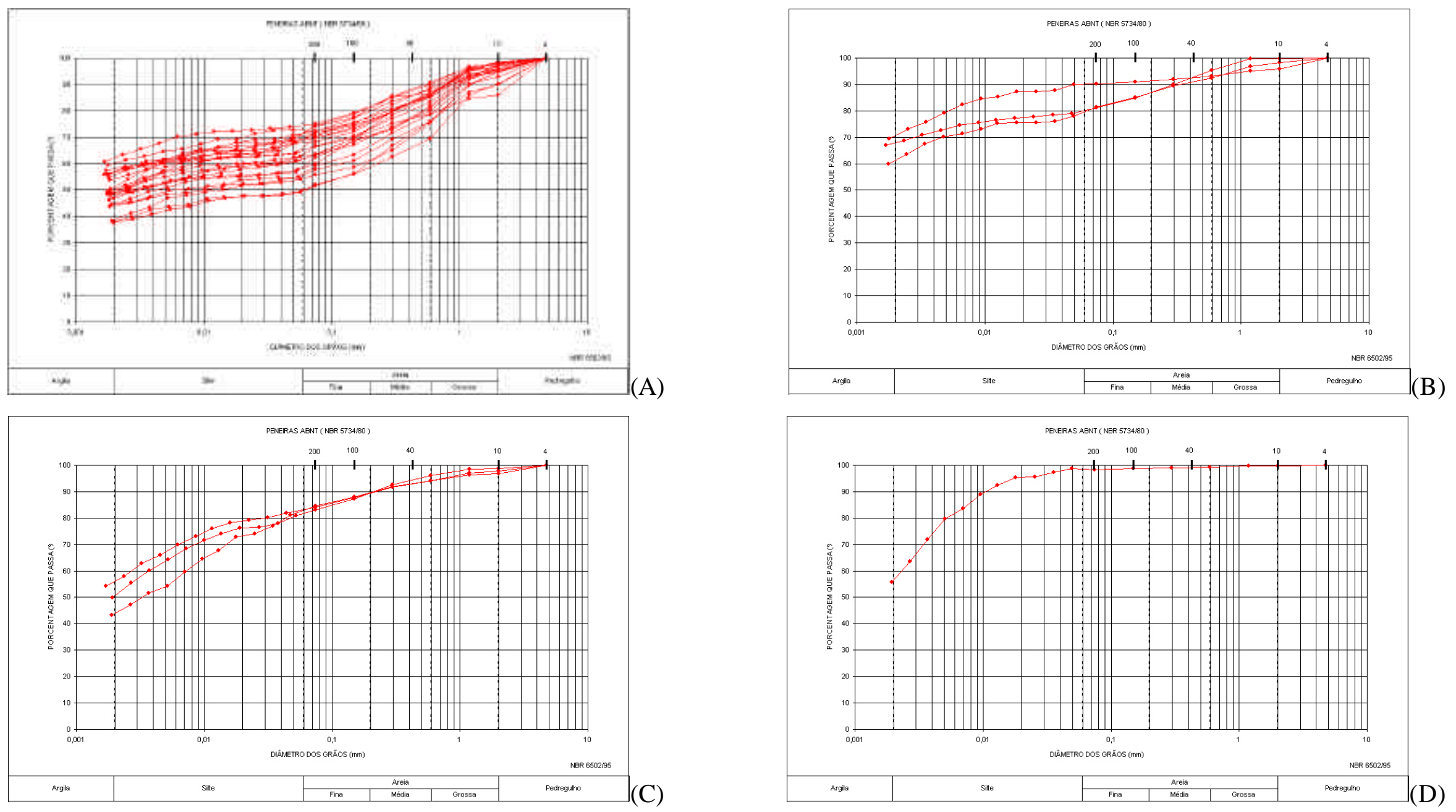

FIGURA 5.16 - Curvas granulométricas das amostras pertencentes aos grupos texturais V (A), VI (B), VII (C) e VIII (D). 


\section{MATERIAIS RETRABALHADOS}

\section{Unidade 01}

É formada por materiais retrabalhados pertencentes ao grupo textural I de origem aluvionar. A unidade 01 ocupa uma superfície de $1,11 \mathrm{~km}^{2}(0,23 \%$ do total) e apresenta espessuras dos seus materiais variando desde inferiores a $0,5 \mathrm{~m}$ a até 4,0 $\mathrm{m}$.

Com relação a textura, conforme mostra a Figura 5.15 (A), o grupo textural I apresenta a fração argilosa inferior a $25 \%$, a siltosa em torno de $25 \%$ e a arenosa sempre superior a $50 \%$.

\section{Unidade 02}

É constituída por materiais retrabalhados pertencentes ao grupo textural VI com espessuras inferiores a $0,5 \mathrm{~m}$ (Figura 5.17). A unidade 02 ocupa uma superfície de $2,32 \mathrm{~km}^{2}(0,48 \%$ do total).

Do ponto de vista textural, a fração argilosa presente nas amostras classificadas para o grupo textural VI predomina sobre a soma das demais (> 50\%), a medida que a fração siltosa e arenosa são sempre ambas inferiores a 25\% (Tabela 5.4).

De acordo com os resultados apontados na Tabela 5.5, a unidade 02 possui comportamento não laterítico, potencial expansivo muito baixo e comportamento relacionado a atividade das argilas considerado pouco ativo.

\section{Unidade 03}

É formada por materiais retrabalhados pertencentes ao grupo textural I de origem coluvionar com espessuras inferiores a $0,5 \mathrm{~m}$ (Sub-unidade 03a) e por materiais com espessuras variáveis (Figura 5.18) que podem atingir até 8,0 m (Subunidade 03b). A unidade 03 estendem-se por uma superfície de 40,61 km² (8,42\% do total). 


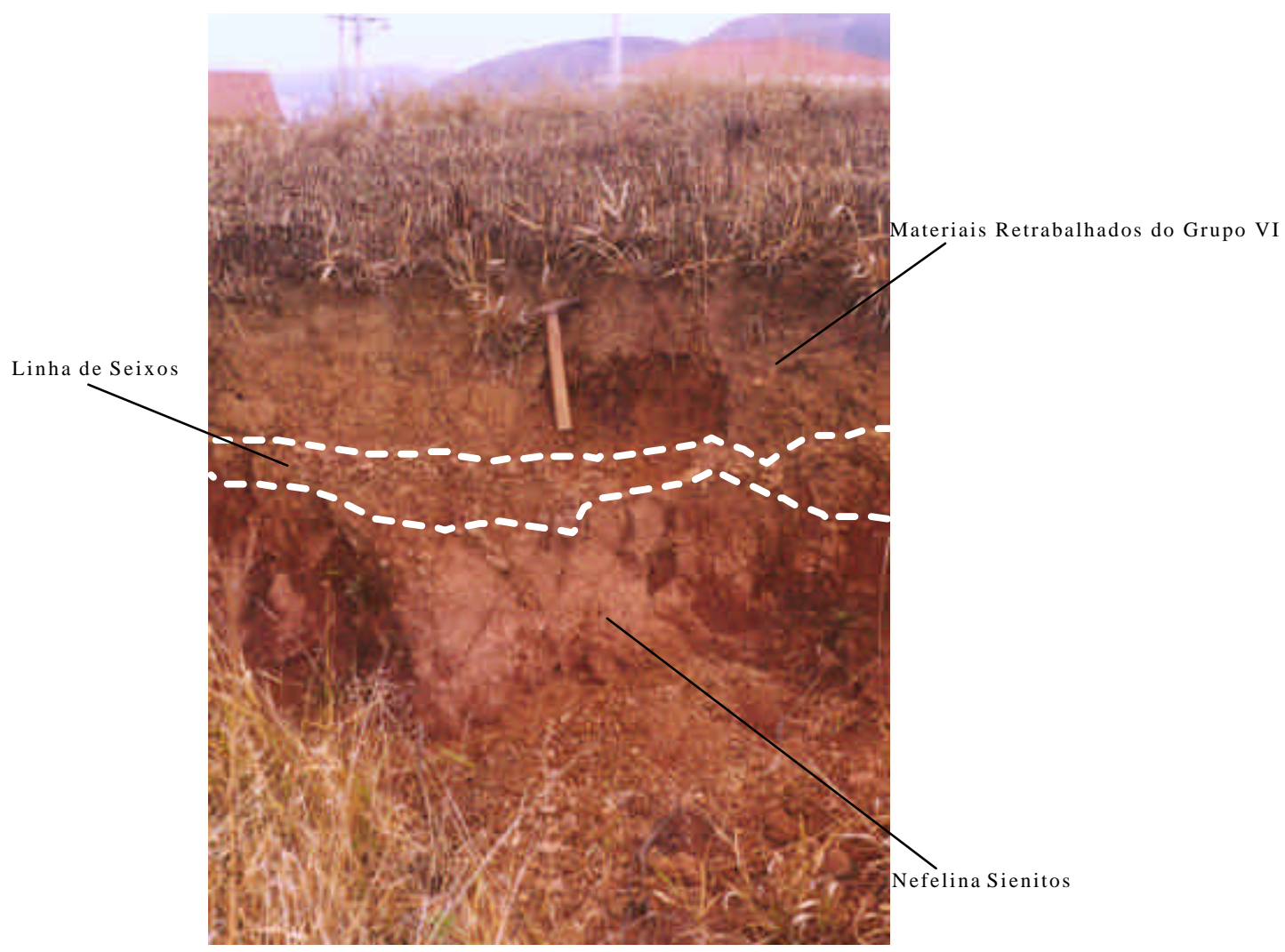

FIGURA 5.17 - Materiais inconsolidados pertencentes a Unidade 02.

TABELA 5.4 - Caracterização da amostra dos materiais inconsolidados que compõem a Unidade 02 quanto a sua localização, granulometria e índices físicos.

\begin{tabular}{|c|c|c|c|c|c|c|}
\hline \multirow{2}{*}{ Amostra } & \multirow{2}{*}{$\begin{array}{l}\text { UTM } \\
(\mathbf{E}-\mathbf{W})\end{array}$} & \multirow{2}{*}{$\begin{array}{l}\text { UTM } \\
(\mathbf{N}-\mathbf{S})\end{array}$} & \multicolumn{3}{|c|}{ Textura } & \multirow{2}{*}{$\underset{\left(\mathrm{g} / \mathrm{cm}^{3}\right)}{\boldsymbol{\rho}_{\mathrm{s}}}$} \\
\hline & & & $\begin{array}{c}\begin{array}{c}\text { Argila } \\
(\%)\end{array} \\
\end{array}$ & $\begin{array}{l}\text { Silte } \\
(\%)\end{array}$ & $\begin{array}{c}\text { Areia } \\
(\%)\end{array}$ & \\
\hline P116-A47 & 340596 & 7587533 & 71 & 19 & 10 & 2,584 \\
\hline
\end{tabular}

TABELA 5.5 - Caracterização da amostra dos materiais inconsolidados que compõem a Unidade 02 pelo método de adsorção de azul de metileno.

\begin{tabular}{|c|c|c|c|c|c|c|c|c|}
\hline Amostra & $\begin{array}{c}\text { C.T.C. } \\
\text { Do Solo } \\
(\mathbf{C m o l} / \mathbf{k g})\end{array}$ & $\begin{array}{c}\text { C.T.C. } \\
\text { da Argila } \\
(\mathbf{C m o l} / \mathbf{k g})\end{array}$ & $\begin{array}{c}\text { S.E. } \\
\text { do Solo } \\
\left(\mathbf{m}^{2} / \mathbf{g}\right)\end{array}$ & $\begin{array}{c}\text { Vb } \\
(\mathbf{g} / \mathbf{1 0 0 g} \text { de solo })\end{array}$ & $\begin{array}{c}\text { Comportamento } \\
\text { Laterítico }\end{array}$ & $\begin{array}{c}\text { Potencial } \\
\text { Expansivo }\end{array}$ & $\begin{array}{c}\text { Acb } \\
(\mathbf{g} / \mathbf{1 0 0 g} \text { de argila })\end{array}$ & Atividade \\
\hline P116-A47 & 7 & 9,86 & 54,46 & 2,23 & Não & Muito Baixo & 3,14 & Pouco Ativa \\
\hline
\end{tabular}




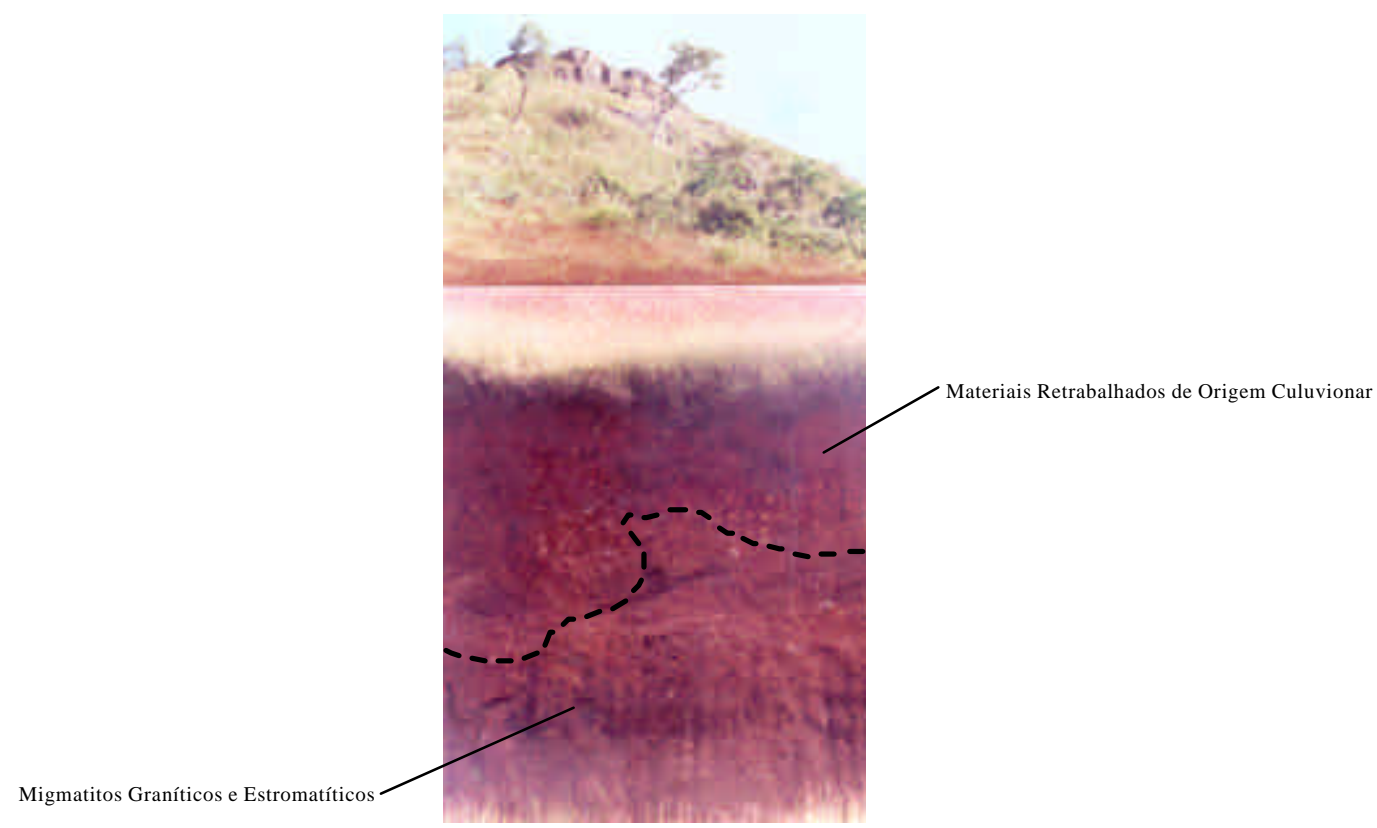

FIGURA 5.18 - Materiais inconsolidados pertencentes a Sub-unidade 03b.

Observando a Tabela 5.7, nota-se que as amostras ensaiadas apontam para um comportamento relacionado a atividade das argilas variando desde normal a nocivo. Contudo, em função da baixa quantidade da fração argilosa (Tabela 5.6) estes materiais inconsolidados apresentam potencial expansivo muito baixo e, portanto, não oferecem risco de acidentes geológicos relacionados a expansão.

\section{MATERIAIS RESIDUAIS DO MACIÇO ALCALINO}

\section{Unidade 04}

É composta por materiais residuais de fonólitos e tinguaítos pertencentes ao grupo textural III com espessuras variando entre 0,5 e 1,5 m (Figura 5.19). A unidade 04 ocupa uma superfície de $3,23 \mathrm{~km}^{2}(0,67 \%$ do total).

Os materiais inconsolidados do grupo textural III são os mais bem graduados encontrados na área em estudo. As concentrações de argila, silte e areia são, em todas as amostras analisadas, superiores a $25 \%$. 
TABELA 5.6 - Caracterização das amostras dos materiais inconsolidados que compõem a Unidade 03 quanto a sua localização, granulometria e índices físicos.

\begin{tabular}{|c|c|c|c|c|c|c|}
\hline \multirow[b]{2}{*}{ Amostra } & \multirow{2}{*}{$\begin{array}{l}\text { UTM } \\
(\mathbf{E}-\mathbf{W})\end{array}$} & \multirow{2}{*}{$\begin{array}{l}\text { UTM } \\
(\mathbf{N}-\mathbf{S})\end{array}$} & \multicolumn{3}{|c|}{ Textura } & \multirow{2}{*}{$\underset{\left(\mathrm{g} / \mathbf{c m}^{3}\right)}{\boldsymbol{\rho}_{\mathrm{s}}}$} \\
\hline & & & \begin{tabular}{|c|}
$\begin{array}{c}\text { Argila } \\
(\%)\end{array}$ \\
\end{tabular} & $\begin{array}{l}\text { Silte } \\
(\%)\end{array}$ & $\begin{array}{c}\text { Areia } \\
(\%)\end{array}$ & \\
\hline P006-A01 & 340591 & 7593473 & 16 & 27 & 57 & 2,726 \\
\hline P029-A20 & 338649 & 7609775 & 8 & 26 & 66 & 2,613 \\
\hline P112-A43 & 339228 & 7592638 & 10 & 24 & 66 & 2,818 \\
\hline
\end{tabular}

TABELA 5.7 - Caracterização das amostras dos materiais inconsolidados que compõem a Unidade 03 pelo método de adsorção de azul de metileno.

\begin{tabular}{|l|c|c|c|c|c|c|c|c|}
\hline Amostra & $\begin{array}{c}\text { C.T.C. } \\
\text { do Solo } \\
(\mathbf{C m o l} / \mathbf{k g})\end{array}$ & $\begin{array}{c}\text { C.T.C. } \\
\text { da Argila } \\
(\mathbf{C m o /} / \mathbf{k g})\end{array}$ & $\begin{array}{c}\text { S.E. do } \\
\text { Solo } \\
\left(\mathbf{m}^{2} / \mathbf{g}\right)\end{array}$ & $\begin{array}{c}\text { Vb } \\
(\mathbf{g} / \mathbf{1 0 0 g} \text { de solo })\end{array}$ & $\begin{array}{c}\text { Comportamento } \\
\text { Laterítico }\end{array}$ & $\begin{array}{c}\text { Potencial } \\
\text { Expansivo }\end{array}$ & $\begin{array}{c}\text { Acb } \\
(\mathbf{g} / \mathbf{1 0 0 g} \text { de argila) }\end{array}$ & Atividade \\
\hline P006-A01 & 7,3 & 45,63 & 56,98 & 2,33 & Não & Muito Baixo & 14,55 & Muito Ativa \\
\hline P029-A20 & 1,5 & 18,75 & 11,86 & 0,48 & Sim & Muito Baixo & 6,06 & Normal \\
\hline P112-A43 & 8,8 & 88,00 & 68,9 & 2,82 & Não & Muito Baixo & 28,16 & Nociva \\
\hline
\end{tabular}

\section{Unidade 05}

É constituída por materiais residuais de fonólitos e tinguaítos pertencentes ao grupo textural IV (Tabela 5.8) apresentando espessuras superiores a 3,0 m. A unidade 05 se estende por uma área de $2,79 \mathrm{~km}^{2}(0,58 \%$ do total).

Com relação a textura, o grupo IV apresenta a fração argilosa e siltosa individualmente sempre em concentrações superiores a $25 \%$ enquanto que, na arenosa predomina valores menores que $25 \%$.

De acordo com os resultados mostrados na Tabela 5.9, a unidade 05 possui comportamento laterítico, potencial expansivo muito baixo e comportamento relacionado a atividade das argilas considerado como pouco ativo.

\section{Unidade 06}

É formada por materiais residuais de fnólitos e tinguaítos pertecentes ao grupo textural VII (Tabela 5.10) com espessuras variando entre 0,5 e 1,5 m. A unidade 06 ocupa uma área de $15,30 \mathrm{~km}^{2}$ (3,17\% do total). 


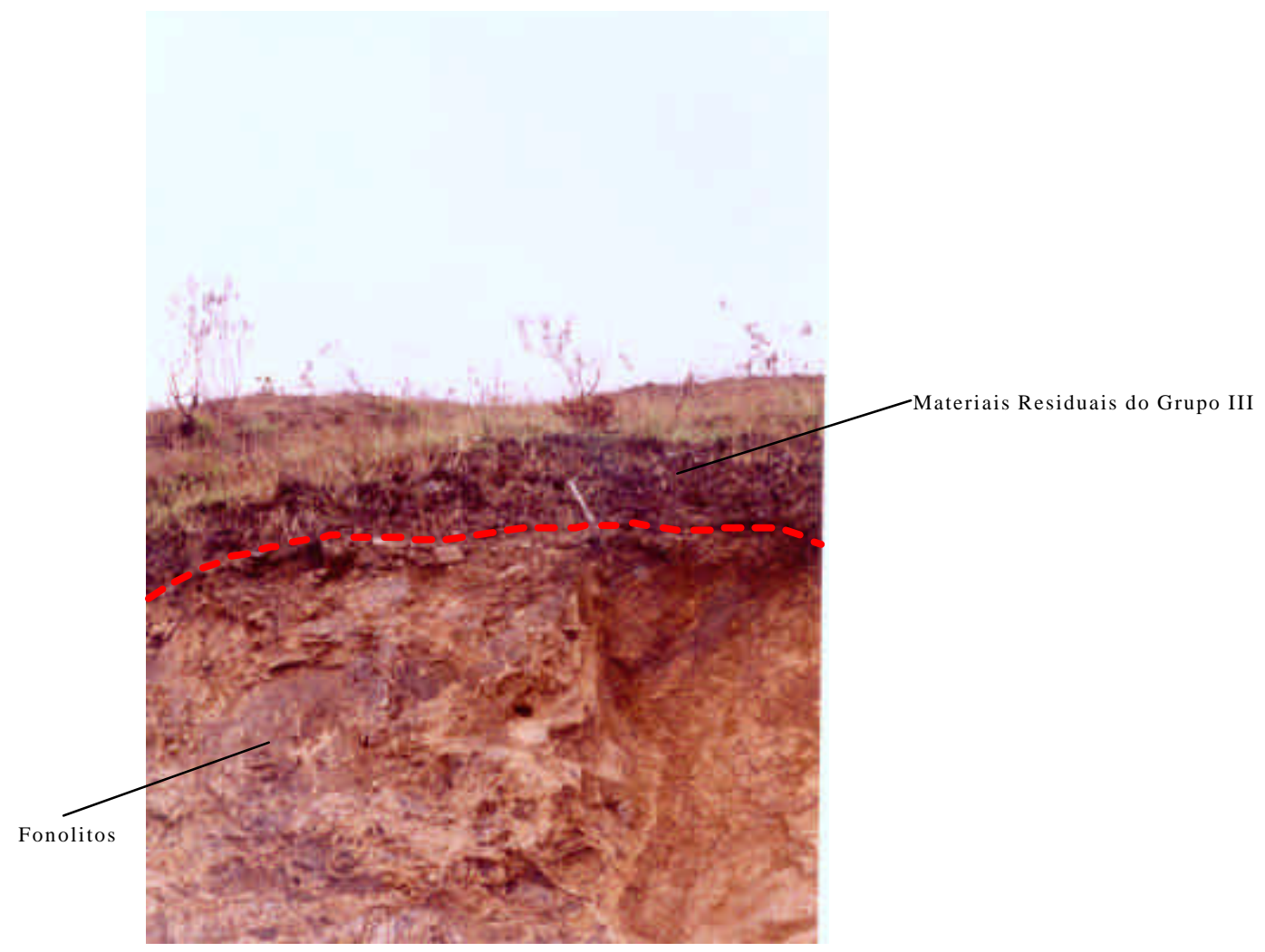

FIGURA 5.19 - Materiais inconsolidados pertencentes a Unidade 04.

TABELA 5.8 - Caracterização da amostra dos materiais inconsolidados que compõem a Unidade 05 quanto a sua localização, granulometria e índices físicos.

\begin{tabular}{|c|c|c|c|c|c|c|}
\hline \multirow{2}{*}{ Amostra } & \multirow{2}{*}{$\begin{array}{c}\text { UTM } \\
(\mathbf{E}-\mathbf{W})\end{array}$} & \multirow{2}{*}{$\begin{array}{l}\text { UTM } \\
(\mathbf{N}-\mathbf{S})\end{array}$} & \multicolumn{3}{|c|}{ Textura } & \multirow{2}{*}{$\underset{\left(\mathbf{g} / \mathbf{c m}^{3}\right)}{\boldsymbol{\rho}_{\mathrm{s}}}$} \\
\hline & & & $\begin{array}{c}\begin{array}{c}\text { Argila } \\
(\%)\end{array} \\
\end{array}$ & $\begin{array}{l}\text { Silte } \\
(\%)\end{array}$ & $\begin{array}{c}\text { Areia } \\
(\%)\end{array}$ & \\
\hline P119-A50 & 331985 & 7590867 & 36 & 41 & 23 & 2,639 \\
\hline
\end{tabular}

TABELA 5.9 - Caracterização da amostra dos materiais inconsolidados que compõem a Unidade 05 pelo método de adsorção de azul de metileno.

\begin{tabular}{|l|c|c|c|c|c|c|c|c|}
\hline Amostra & $\begin{array}{c}\text { C.T.C. } \\
\text { do Solo } \\
(\mathbf{C m o l} / \mathbf{k g})\end{array}$ & $\begin{array}{c}\text { C.T.C. } \\
\text { da Argila } \\
(\mathbf{C m o l} / \mathbf{k g})\end{array}$ & $\begin{array}{c}\text { S.E. } \\
\text { do Solo } \\
\left(\mathbf{m}^{2} / \mathbf{g}\right)\end{array}$ & $\begin{array}{c}\text { Vb } \\
(\mathbf{g} / \mathbf{1 0 0 g} \text { de solo })\end{array}$ & $\begin{array}{c}\text { Comportamento } \\
\text { Laterítico }\end{array}$ & $\begin{array}{c}\text { Potencial } \\
\text { Expansivo }\end{array}$ & $\begin{array}{c}\text { Acb } \\
(\mathbf{g} / \mathbf{1 0 0 g} \text { de argila) }\end{array}$ & Atividade \\
\hline P119-A50 & 3,7 & 10,28 & 29,14 & 1,19 & Sim & Muito Baixo & 3,31 & Pouco Ativa \\
\hline
\end{tabular}


TABELA 5.10 - Caracterização da amostra dos materiais inconsolidados que compõem a Unidade 06 quanto a sua localização, granulometria e índices físicos.

\begin{tabular}{|l|c|c|c|c|c|c|c|c|c|c|}
\hline \multirow{2}{*}{ Amostra } & \multirow{2}{*}{$\begin{array}{c}\text { UTM } \\
(\mathbf{E}-\mathbf{W})\end{array}$} & \multirow{2}{*}{$\begin{array}{c}\text { UTM } \\
(\mathbf{N}-\mathbf{S})\end{array}$} & $\begin{array}{c}\text { Argila } \\
(\boldsymbol{\%})\end{array}$ & $\begin{array}{c}\text { Silte } \\
(\boldsymbol{\%})\end{array}$ & $\begin{array}{c}\text { Areia } \\
(\boldsymbol{\%})\end{array}$ & $\begin{array}{c}\mathbf{\rho}_{\mathrm{s}} \\
\left(\mathbf{g} / \mathbf{c m}^{\mathbf{3}}\right)\end{array}$ & $\begin{array}{c}\mathbf{\rho}_{\mathbf{d}} \\
\left(\mathbf{g} / \mathbf{c m}^{\mathbf{3}}\right)\end{array}$ & $\mathbf{E}$ & $\mathbf{n}(\boldsymbol{\%})$ & $\mathbf{S r}(\boldsymbol{\%})$ \\
\hline P118-A49 & 333985 & 7589996 & 51 & 31 & 18 & 2,713 & 0,714 & 2,8 & 73,67 & 32,14 \\
\hline
\end{tabular}

Texturalmente a concentração dos materiais finos no grupo textural VII é em torno de $80 \%$. A fração argilosa perfaz $50 \%$ nas amostras analisadas, a siltosa sempre superior a $25 \%$ enquanto que arenosa não ultrapassa $20 \%$

Os resultados apontados na Tabela 5.11 mostram que a unidade 06 possui comportamento não laterítico, potencial expansivo muito baixo e comportamento relacionado a atividade das argilas considerado como normal.

\section{Unidade 07}

É composta por materiais residuais de fnólitos e tinguaítos pertecentes ao grupo textural VIII apresentando espessuras superiores a 3,0 m (Figura 5.20). A unidade 07 se estende por uma superfície de $26,00 \mathrm{~km}^{2}$ (5,39\% do total).

O grupo textural VIII ocorre exclusivamente nessa unidade de materiais inconsolidados. Nesse grupo a fração arenosa é praticamente inexistente enquanto que a fração argilosa presente ocorre em concentrações superiores a 50\% (Tabela 5.12).

Do ponto de vista geotécnico, os materiais inconsolidados apresentam comportamento não laterítico, potencial expansivo médio e o comportamento relacionado a atividade das argilas considerado como ativo, portanto podem oferecer algum risco de acidente geológico dependendo da solicitação antrópica conferida ao meio físico (Tabela 5.13). 
TABELA 5.11 - Caracterização da amostra dos materiais inconsolidados que compõem a Unidade 06 pelo método de adsorção de azul de metileno.

\begin{tabular}{|c|c|c|c|c|c|c|c|c|}
\hline Amostra & $\begin{array}{c}\text { C.T.C. } \\
\text { do Solo } \\
(\mathbf{C m o l} / \mathbf{k g})\end{array}$ & $\begin{array}{c}\text { C.T.C. } \\
\text { da Argila } \\
(\mathbf{C m o l} / \mathbf{k g})\end{array}$ & $\begin{array}{c}\text { S.E. } \\
\text { do Solo } \\
\left(\mathbf{m}^{2} / \mathbf{g}\right)\end{array}$ & $\begin{array}{c}\text { Vb } \\
(\mathbf{g} / \mathbf{1 0 0 g} \text { de solo })\end{array}$ & $\begin{array}{c}\text { Comportamento } \\
\text { Laterítico }\end{array}$ & $\begin{array}{c}\text { Potencial } \\
\text { Expansivo }\end{array}$ & $\begin{array}{c}\text { Acb } \\
(\mathbf{g} / \mathbf{1 0 0 g} \text { de argila) }\end{array}$ & Atividade \\
\hline P118-A49 & 10,8 & 21,18 & 84,36 & 3,45 & Não & Muito Baixo & 6,76 & Normal \\
\hline
\end{tabular}

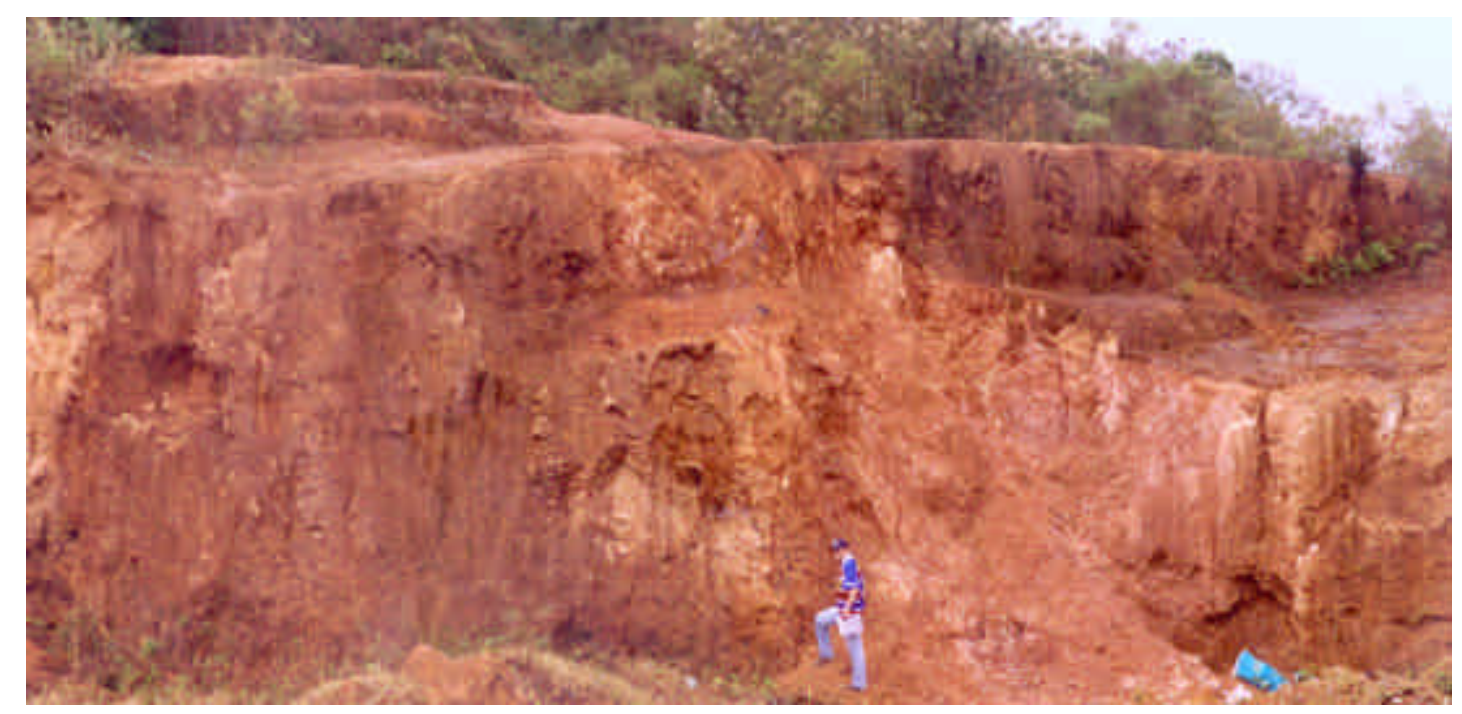

FIGURA 5.20 - Materiais inconsolidados pertencentes a Unidade 07.

TABELA 5.12 - Caracterização da amostra dos materiais inconsolidados que compõem a Unidade 07 quanto a sua localização, granulometria e índices físicos.

\begin{tabular}{|c|c|c|c|c|c|c|}
\hline \multirow{2}{*}{ Amostra } & \multirow{2}{*}{$\begin{array}{c}\text { UTM } \\
(\mathbf{E}-\mathbf{W})\end{array}$} & \multirow{2}{*}{$\begin{array}{c}\text { UTM } \\
(\mathbf{N}-S)\end{array}$} & \multicolumn{3}{|c|}{ Textura } & \multirow{2}{*}{\begin{tabular}{c}
$\boldsymbol{\rho}_{\mathbf{s}}$ \\
\cline { 4 - 5 }
\end{tabular}} \\
\cline { 4 - 6 } & & $\begin{array}{c}\text { Argila } \\
(\mathbf{\%})\end{array}$ & $\begin{array}{c}\text { Silte } \\
(\boldsymbol{\%})\end{array}$ & $\begin{array}{c}\text { Areia } \\
(\mathbf{\%})\end{array}$ & \\
\hline P113-A44 & 340336 & 7590413 & 57 & 42 & 1 & 2,612 \\
\hline
\end{tabular}

TABELA 5.13 - Caracterização da amostra dos materiais inconsolidados que compõem a Unidade 07 pelo método de adsorção de azul de metileno.

\begin{tabular}{|c|c|c|c|c|c|c|c|c|}
\hline Amostra & $\begin{array}{c}\text { C.T.C. } \\
\text { Do Solo } \\
(\mathbf{C m o l} / \mathbf{k g})\end{array}$ & $\begin{array}{c}\text { C.T.C. } \\
\text { da Argila } \\
(\mathbf{C m o l} / \mathbf{k g})\end{array}$ & $\begin{array}{c}\text { S.E. } \\
\mathbf{d o} \text { Solo } \\
\left(\mathbf{m}^{2} / \mathbf{g}\right)\end{array}$ & $\begin{array}{c}\text { Vb } \\
(\mathbf{g} / \mathbf{1 0 0 g} \text { de solo })\end{array}$ & $\begin{array}{c}\text { Comportamento } \\
\text { Laterítico }\end{array}$ & $\begin{array}{c}\text { Potencial } \\
\text { Expansivo }\end{array}$ & $\begin{array}{c}\text { Acb } \\
(\mathbf{g} / \mathbf{1 0 0 g} \text { de argila) }\end{array}$ & Atividade \\
\hline P113-A44 & 23,1 & 40,53 & 180,85 & 7,39 & Não & Médio & 12,97 & Ativa \\
\hline
\end{tabular}




\section{Unidade 08}

É constituída por materiais residuais de nefelina sienitos pertencentes ao grupo textural III (Tabela 5.14) com espessuras variando entre 0,5 e 1,5 m. A unidade 08 se estende por uma área de $44,89 \mathrm{~km}^{2}$ (9,31\% do total).

De acordo com os resultados presentes na Tabela 5.15, a unidade 08 possui comportamento não laterítico, potencial expansivo baixo e comportamento relacionado a atividade das argilas considerado como muito ativo.

\section{MATERIAIS RESIDUAIS DO COMPLEXO VARGINHA}

\section{Unidade 09}

É formada por materiais residuais de charnockitos pertencentes ao grupo textural III (Tabela 5.16) com espessuras variando entre 1,5 e 3,0 m. A unidade 09 ocupa uma área de $35,62 \mathrm{~km}^{2}(7,39 \%$ do total).

Com relação as suas propriedades geotécnicas, segundo a Tabela 5.17, a unidade apresenta predominantemente comportamento não laterítico, potencial expansivo baixo e comportamento relacionado a atividade das argilas variando de pouco ativo a normal.

\section{Unidade 10}

É formada por materiais residuais de chanockitos pertencentes ao grupo textural V (Tabela 5.18) apresentando espessuras inferiores a 0,5 m (Sub-unidade 10a), entre 0,5 e 1,5 (Sub-unidade 10b), entre 1,5 e 3,0 m (Sub-unidade 10c) e superiores a 3,0 m (Sub-unidade 10d) podendo atingir até $6,0 \mathrm{~m}$. A unidade 10 (Figura 5.21) ocupa uma área de 38,55 $\mathrm{km}^{2}$ (7,99\% do total).

Texturalmente o grupo V se caracteriza pela concentração da fração siltosa sempre inferior a $25 \%$, enquanto que areia e argila são individualmente superiores à mesma concentração, entretanto esta última freqüentemente perfaz a maior parte das amostras analisadas, ou seja é superior a $50 \%$.

De acordo com os resultados mostrados na Tabela 5.19, a unidade 10 possui potencial expansivo muito baixo e comportamento relacionado a atividade das argilas variando de pouco ativo a normal. 
TABELA 5.14 - Caracterização da amostra dos materiais inconsolidados que compõem a Unidade 08 quanto a sua localização, granulometria e índices físicos.

\begin{tabular}{|c|c|c|c|c|c|c|}
\hline \multirow{2}{*}{ Amostra } & \multirow{2}{*}{$\begin{array}{c}\text { UTM } \\
(\mathbf{E}-\mathbf{W})\end{array}$} & \multirow{2}{*}{$\begin{array}{l}\text { UTM } \\
(\mathbf{N}-S)\end{array}$} & \multicolumn{3}{|c|}{ Textura } & \multirow{2}{*}{$\underset{\left(\mathrm{g} / \mathrm{cm}^{3}\right)}{\rho_{\mathrm{s}}}$} \\
\hline & & & \begin{tabular}{|c}
$\begin{array}{c}\text { Argila } \\
(\%)\end{array}$ \\
\end{tabular} & $\begin{array}{r}\text { Silte } \\
(\%)\end{array}$ & $\begin{array}{c}\text { Areia } \\
(\%)\end{array}$ & \\
\hline P115-A46 & 341523 & 7588830 & 29 & 34 & 37 & 2,686 \\
\hline
\end{tabular}

TABELA 5.15 - Caracterização da amostra dos materiais inconsolidados que compõem a Unidade 08 pelo método de adsorção de azul de metileno.

\begin{tabular}{|l|c|c|c|c|c|c|c|c|}
\hline Amostra & $\begin{array}{c}\text { C.T.C. } \\
\text { do Solo } \\
(\mathbf{C m o l} / \mathbf{k g})\end{array}$ & $\begin{array}{c}\text { C.T.C. } \\
\text { da Argila } \\
(\mathbf{C m o l} / \mathbf{k g})\end{array}$ & $\begin{array}{c}\text { S.E. } \\
\text { do Solo } \\
\left(\mathbf{m}^{2} / \mathbf{g}\right)\end{array}$ & $\begin{array}{c}\text { Vb } \\
(\mathbf{g} / \mathbf{1 0 0 g} \text { de solo })\end{array}$ & $\begin{array}{c}\text { Comportamento } \\
\text { Laterítico }\end{array}$ & $\begin{array}{c}\text { Potencial } \\
\text { Expansivo }\end{array}$ & $\begin{array}{c}\text { Acb } \\
(\mathbf{g} / \mathbf{1 0 0 g} \text { de argila) }\end{array}$ & Atividade \\
\hline P115-A46 & 13,5 & 46,55 & 105,78 & 4,32 & Não & Baixo & 14,91 & Muita Ativa \\
\hline
\end{tabular}

TABELA 5.16 - Caracterização das amostras dos materiais inconsolidados que compõem a Unidade 09 quanto a sua localização, granulometria e índices físicos.

\begin{tabular}{|c|c|c|c|c|c|c|c|c|c|c|}
\hline \multirow[b]{2}{*}{ Amostra } & \multirow{2}{*}{$\begin{array}{c}\text { UTM } \\
(\mathbf{E}-\mathbf{W})\end{array}$} & \multirow{2}{*}{$\begin{array}{l}\text { UTM } \\
\text { (N-S) }\end{array}$} & \multicolumn{3}{|c|}{ Textura } & \multirow[b]{2}{*}{$\underset{\left(\mathrm{g} / \mathbf{c m}^{3}\right)}{\boldsymbol{\rho}_{\mathrm{s}}}$} & \multirow[b]{2}{*}{$\underset{\left(\mathrm{g} / \mathrm{cm}^{3}\right)}{\boldsymbol{\rho}_{\mathrm{d}}}$} & \multirow[b]{2}{*}{ e } & \multirow[b]{2}{*}{ n $(\%)$} & \multirow[b]{2}{*}{$\operatorname{Sr}(\%)$} \\
\hline & & & \begin{tabular}{|c|}
$\begin{array}{c}\text { Argila } \\
(\%)\end{array}$ \\
\end{tabular} & $\begin{array}{l}\text { Silte } \\
(\%)\end{array}$ & $\begin{array}{c}\begin{array}{c}\text { Areia } \\
(\%)\end{array} \\
\end{array}$ & & & & & \\
\hline $\mathrm{P} 032-\mathrm{A} 22$ & 339263 & 7601609 & 38 & 31 & 31 & 2,643 & 1,293 & 1,04 & 51,09 & 50,55 \\
\hline P033-A23 & 340890 & 7603409 & 34 & 30 & 36 & 2,637 & 1,182 & 1,23 & 55,18 & 69,67 \\
\hline P034-A24 & 341914 & 7603056 & 38 & 32 & 30 & 2,81 & 1,245 & 1,26 & 55,69 & 72,47 \\
\hline P044-A27 & 334159 & 7597782 & 42 & 25 & 33 & 2,701 & 1,298 & 1,08 & 51,93 & 70,15 \\
\hline
\end{tabular}

TABELA 5.17 - Caracterização das amostras dos materiais inconsolidados que compõem a Unidade 09 pelo método de adsorção de azul de metileno.

\begin{tabular}{|l|c|c|c|c|c|c|c|c|}
\hline Amostra & $\begin{array}{c}\text { C.T.C. } \\
\text { do Solo } \\
(\mathbf{C m o l} / \mathbf{k g})\end{array}$ & $\begin{array}{c}\text { C.T.C. } \\
\text { da Argila } \\
(\mathbf{C m o l} / \mathbf{k g})\end{array}$ & $\begin{array}{c}\text { S.E. } \\
\mathbf{d o} \text { Solo } \\
\left(\mathbf{m}^{\mathbf{2}} \mathbf{g}\right)\end{array}$ & $\begin{array}{c}\text { Vb } \\
(\mathbf{g} / \mathbf{1 0 0 g} \text { de solo })\end{array}$ & $\begin{array}{c}\text { Comportamento } \\
\text { Laterítico }\end{array}$ & $\begin{array}{c}\text { Potencial } \\
\text { Expansivo }\end{array}$ & $\begin{array}{c}\text { Acb } \\
(\mathbf{g} / \mathbf{1 0 0 g} \text { de argila) }\end{array}$ & Atividade \\
\hline P032-A22 & 6,1 & 16,05 & 47,73 & 1,95 & Não & Muito Baixo & 5,13 & Normal \\
\hline P033-A23 & 3,5 & 10,29 & 27,01 & 1,1 & Sim & Muito Baixo & 3,25 & Pouco Ativa \\
\hline P034-A24 & 7,4 & 19,47 & 57,98 & 2,37 & Não & Muito Baixo & 6,24 & Normal \\
\hline P044-A27 & 6,8 & 16,19 & 53,33 & 2,18 & Não & Muito Baixo & 5,19 & Normal \\
\hline
\end{tabular}


TABELA 5.18 - Caracterização das amostras dos materiais inconsolidados que compõem a Unidade 10 quanto a sua localização, granulometria e índices físicos.

\begin{tabular}{|c|c|c|c|c|c|c|c|c|c|c|}
\hline \multirow[b]{2}{*}{ Amostra } & \multirow{2}{*}{$\begin{array}{c}\text { UTM } \\
(\mathbf{E}-\mathbf{W})\end{array}$} & \multirow{2}{*}{$\begin{array}{l}\text { UTM } \\
(\mathbf{N}-\mathbf{S})\end{array}$} & \multicolumn{3}{|c|}{ Textura } & \multirow{2}{*}{$\underset{\left(\mathrm{g} / \mathrm{cm}^{3}\right)}{\boldsymbol{\rho}_{\mathrm{s}}}$} & \multirow{2}{*}{$\underset{\left(\mathrm{g} / \mathrm{cm}^{3}\right)}{\rho_{\mathrm{d}}}$} & \multirow[b]{2}{*}{ e } & \multirow[b]{2}{*}{$n(\%)$} & \multirow[b]{2}{*}{$\operatorname{Sr}(\%)$} \\
\hline & & & \begin{tabular}{|c} 
Argila \\
$(\%)$
\end{tabular} & $\begin{array}{c}\text { Silte } \\
(\%)\end{array}$ & \begin{tabular}{|c|} 
Areia \\
$(\%)$
\end{tabular} & & & & & \\
\hline P009-A04 & 336152 & 7596924 & 44 & 12 & 44 & 2,65 & & & & \\
\hline P010-A06 & 336708 & 7596686 & 45 & 13 & 42 & 2,654 & & & & \\
\hline P011-A07 & 336237 & 7600234 & 49 & 23 & 28 & 2,677 & & & & \\
\hline P016-A11 & 337381 & 7596525 & 45 & 9 & 46 & 2,613 & & & & \\
\hline $\mathrm{P} 035-\mathrm{A} 25$ & 335421 & 7594565 & 62 & 12 & 26 & 2,764 & 0,925 & 1,99 & 66,55 & 44,41 \\
\hline P040-A26 & 336239 & 7597774 & 57 & 10 & 33 & 2,687 & 1,185 & 1,27 & 55,91 & 56,66 \\
\hline P046-A28 & 335296 & 7598024 & 48 & 22 & 30 & 2,7 & 1,294 & 1,09 & 52,08 & 66,79 \\
\hline P049-A29 & 333285 & 7601134 & 49 & 10 & 41 & 2,723 & & & & \\
\hline P050-A30 & 332181 & 7601625 & 38 & 12 & 50 & 2,558 & & & & \\
\hline P060-A36 & 337036 & 7602218 & 48 & 14 & 38 & 2,664 & 1,244 & 1,14 & 53,32 & 48,3 \\
\hline P110-A42 & 337896 & 7591633 & 47 & 17 & 36 & 2,601 & & & & \\
\hline
\end{tabular}

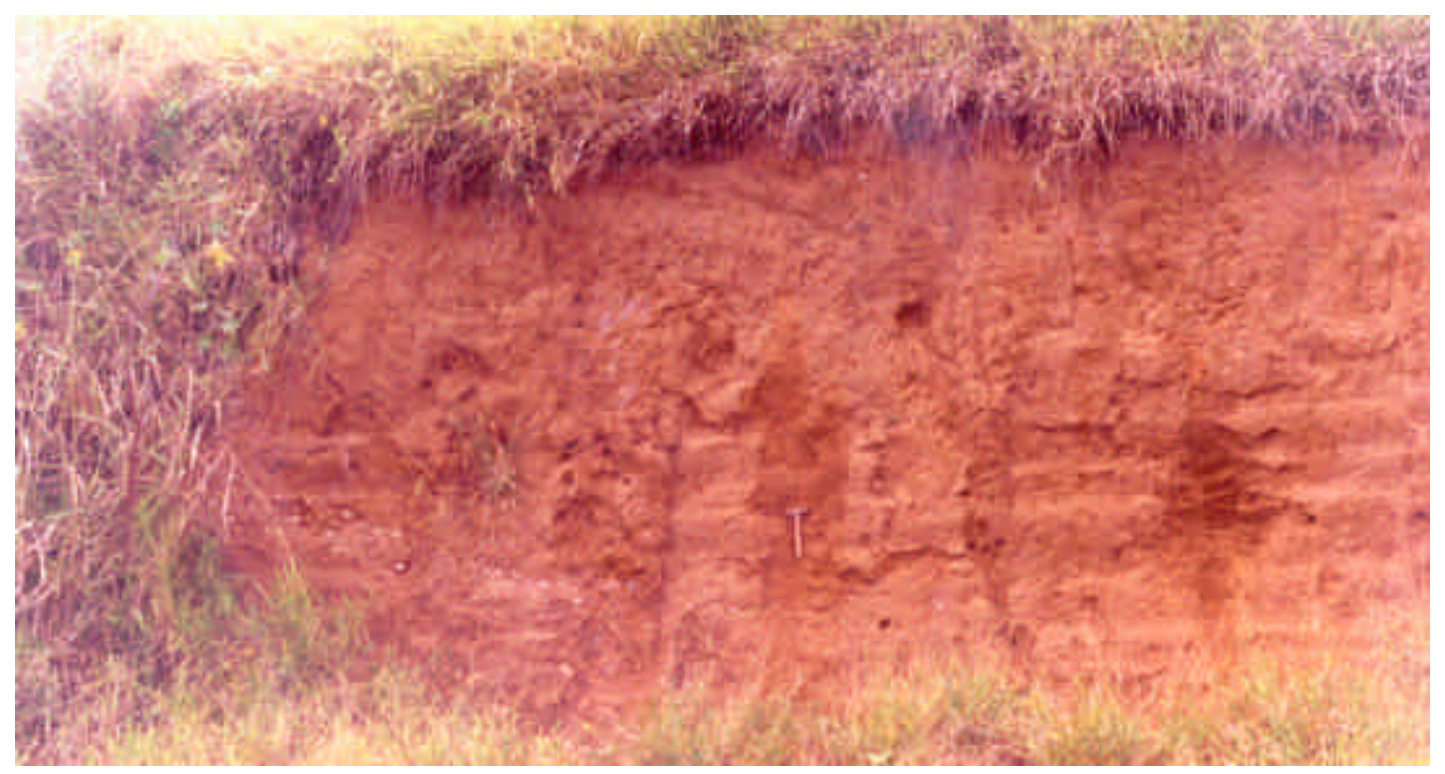

FIGURA 5.21 - Materiais inconsolidados pertencentes a Sub-unidade 10d. 
TABELA 5.19 - Caracterização das amostras dos materiais inconsolidados que compõem a Unidade 10 pelo método de adsorção de azul de metileno.

\begin{tabular}{|l|c|c|c|c|c|c|c|c|}
\hline Amostra & $\begin{array}{c}\text { C.T.C. } \\
\mathbf{d o ~ S o l o ~} \\
(\mathbf{C m o l} / \mathbf{k g})\end{array}$ & $\begin{array}{c}\text { C.T.C. } \\
\mathbf{d a} \text { Argila } \\
(\mathbf{C m o l} / \mathbf{k g})\end{array}$ & $\begin{array}{c}\text { S.E. } \\
\mathbf{d o S o l o} \\
\left(\mathbf{m}^{2} / \mathbf{g}\right)\end{array}$ & $\begin{array}{c}\text { Vb } \\
(\mathbf{g} / \mathbf{1 0 0 g} \text { de solo })\end{array}$ & $\begin{array}{c}\text { Comportamento } \\
\text { Laterítico }\end{array}$ & $\begin{array}{c}\text { Potencial } \\
\text { Expansivo }\end{array}$ & $\begin{array}{c}\text { Acb } \\
(\mathbf{g} / \mathbf{1 0 0 g} \text { de argila) }\end{array}$ & Atividade \\
\hline P009-A04 & 4,4 & 10,00 & 34,63 & 1,42 & Sim & Muito Baixo & 3,22 & Pouco Ativa \\
\hline P011-A07 & 5,6 & 11,43 & 43,95 & 1,8 & Não & Muito Baixo & 3,67 & Pouco Ativa \\
\hline P016-A11 & 3,9 & 8,67 & 30,41 & 1,24 & Sim & Muito Baixo & 2,76 & Argila Inativa \\
\hline P035-A25 & 4,8 & 7,74 & 37,46 & 1,53 & Não & Muito Baixo & 2,47 & Argila Inativa \\
\hline P040-A26 & 4,8 & 8,42 & 37,29 & 1,52 & Não & Muito Baixo & 2,67 & Argila Inativa \\
\hline P046-A28 & 4,3 & 8,96 & 33,58 & 1,37 & Sim & Muito Baixo & 2,86 & Argila Inativa \\
\hline P049-A29 & 3,6 & 7,35 & 27,89 & 1,14 & Sim & Muito Baixo & 2,33 & Argila Inativa \\
\hline P050-A30 & 5,6 & 14,74 & 43,66 & 1,78 & Não & Muito Baixo & 4,7 & Pouco Ativa \\
\hline P060-A36 & 8,6 & 17,92 & 67,23 & 2,75 & Não & Muito Baixo & 5,72 & Normal \\
\hline P110-A42 & 3,2 & 6,81 & 25,07 & 1,02 & Sim & Muito Baixo & 2,18 & Argila Inativa \\
\hline
\end{tabular}

\section{Unidade 11}

É composta por materiais residuais de charnockitos pertencentes ao grupo textural VI (Tabela 5.20) apresentando espessuras superiores a 3,0 m podendo atingir até $3,5 \mathrm{~m}$. A unidade 11 ocupa uma área de $3,48 \mathrm{~km}^{2}(0,72 \%$ do total).

De acordo com os resultados mostrados na Tabela 5.21, a unidade 11 possui comportamento não laterítico, potencial expansivo muito baixo e comportamento relacionado a atividade das argilas considerado inativo.

\section{Unidade 12}

É a menor unidade de materiais inconsolidados mapeada com apenas 0,36 $\mathrm{km}^{2}$ (0,07\% do total). A unidade 12 é constituída por materiais residuais de granulitos quartzo-feldspáticos pertencentes ao grupo textural III com espessuras variando entre 1,5 e $3,0 \mathrm{~m}$.

\section{Unidade 13}

É formada por materiais residuais de granulitos quartzo-feldspáticos (Figura 5.22) pertencentes ao grupo textural V (Tabela 5.22) apresentando espessuras inferiores a 0,5 m (Sub-unidade 13a), entre 1,5 e 3,0 m (Sub-unidade 13b) e superiores a 3,0 m (Sub-unidade 13c) podendo atingir até 3,9 m. A unidade 13 se estende por uma área de $57,12 \mathrm{~km}^{2}(11,84 \%$ do total). 
TABELA 5.20 - Caracterização da amostra dos materiais inconsolidados que compõem a Unidade 11 quanto a sua localização, granulometria e índices físicos.

\begin{tabular}{|c|c|c|c|c|c|c|c|c|c|c|}
\hline \multirow[b]{2}{*}{ Amostra } & \multirow{2}{*}{$\begin{array}{c}\text { UTM } \\
(\mathbf{E}-\mathbf{W})\end{array}$} & \multirow{2}{*}{$\begin{array}{l}\text { UTM } \\
\text { (N-S) }\end{array}$} & \multicolumn{3}{|c|}{ Textura } & \multirow{2}{*}{$\underset{\left(\mathrm{g} / \mathrm{cm}^{3}\right)}{\boldsymbol{\rho}_{\mathrm{s}}}$} & \multirow{2}{*}{$\underset{\left(\mathrm{g} / \mathrm{cm}^{3}\right)}{\rho_{\mathrm{d}}}$} & \multirow[b]{2}{*}{$\mathbf{e}$} & \multirow[b]{2}{*}{$\mathrm{n}(\%)$} & \multirow[b]{2}{*}{$\mathrm{Sr}(\%)$} \\
\hline & & & \begin{tabular}{|c|} 
Argila \\
$(\%)$
\end{tabular} & $\begin{array}{l}\text { Silte } \\
(\%)\end{array}$ & \begin{tabular}{|c|} 
Areia \\
$(\%)$
\end{tabular} & & & & & \\
\hline P063-A37 & 336795 & 7604844 & 68 & 12 & 20 & 2,672 & 0,896 & 1,98 & 66,47 & 49,64 \\
\hline
\end{tabular}

TABELA 5.21 - Caracterização da amostra dos materiais inconsolidados que compõem a Unidade 11 pelo método de adsorção de azul de metileno.

\begin{tabular}{|l|c|c|c|c|c|c|c|c|}
\hline Amostra & $\begin{array}{c}\text { C.T.C. } \\
\text { do Solo } \\
(\mathbf{C m o l} / \mathbf{k g})\end{array}$ & $\begin{array}{c}\text { C.T.C. } \\
\text { da Argila } \\
(\mathbf{C m o l} / \mathbf{k g})\end{array}$ & $\begin{array}{c}\text { S.E. } \\
\text { do Solo } \\
\left(\mathbf{m}^{2} / \mathbf{g}\right)\end{array}$ & $\begin{array}{c}\text { Vb } \\
(\mathbf{g} / \mathbf{1 0 0 g} \text { de solo })\end{array}$ & $\begin{array}{c}\text { Comportamento } \\
\text { Laterítico }\end{array}$ & $\begin{array}{c}\text { Potencial } \\
\text { Expansivo }\end{array}$ & $\begin{array}{c}\text { Acb } \\
(\mathbf{g} / \mathbf{1 0 0 g} \text { de argila) }\end{array}$ & Atividade \\
\hline P063-A37 & 6,2 & 9,12 & 48,2 & 1,97 & Não & Muito Baixo & 2,9 & Argila Inativa \\
\hline
\end{tabular}

De acordo com os resultados mostrados na Tabela 5.23, a unidade 13 possui potencial expansivo muito baixo e comportamento relacionado a atividade das argilas variando de inativo a pouco ativo.

\section{Unidade 14}

É composta por materiais residuais de granulitos quartzo-feldspáticos pertencentes ao grupo. textural VI apresentando espessuras superiores a 3,0 m. A unidade 14 ocupa uma área de $2,00 \mathrm{~km}^{2}(0,41 \%$ do total).

\section{Unidade 15}

A unidade 15 ocupa uma área de $18,39 \mathrm{~km}^{2}$ (3,81\% do total). É constituída por materiais residuais de migmatitos graníticos e estromatíticos pertencentes ao grupo textural II (Tabela 5.24) com espessuras variando entre 1,5 e 3,0 m.

A unidade 15, segundo a Tabela 5.25, apresenta atividade das argilas variando de normal a nociva, contudo não deve apresentar problemas com relação a expansão, pois o potencial expansivo de seus materiais varia de baixo a muito baixo. 


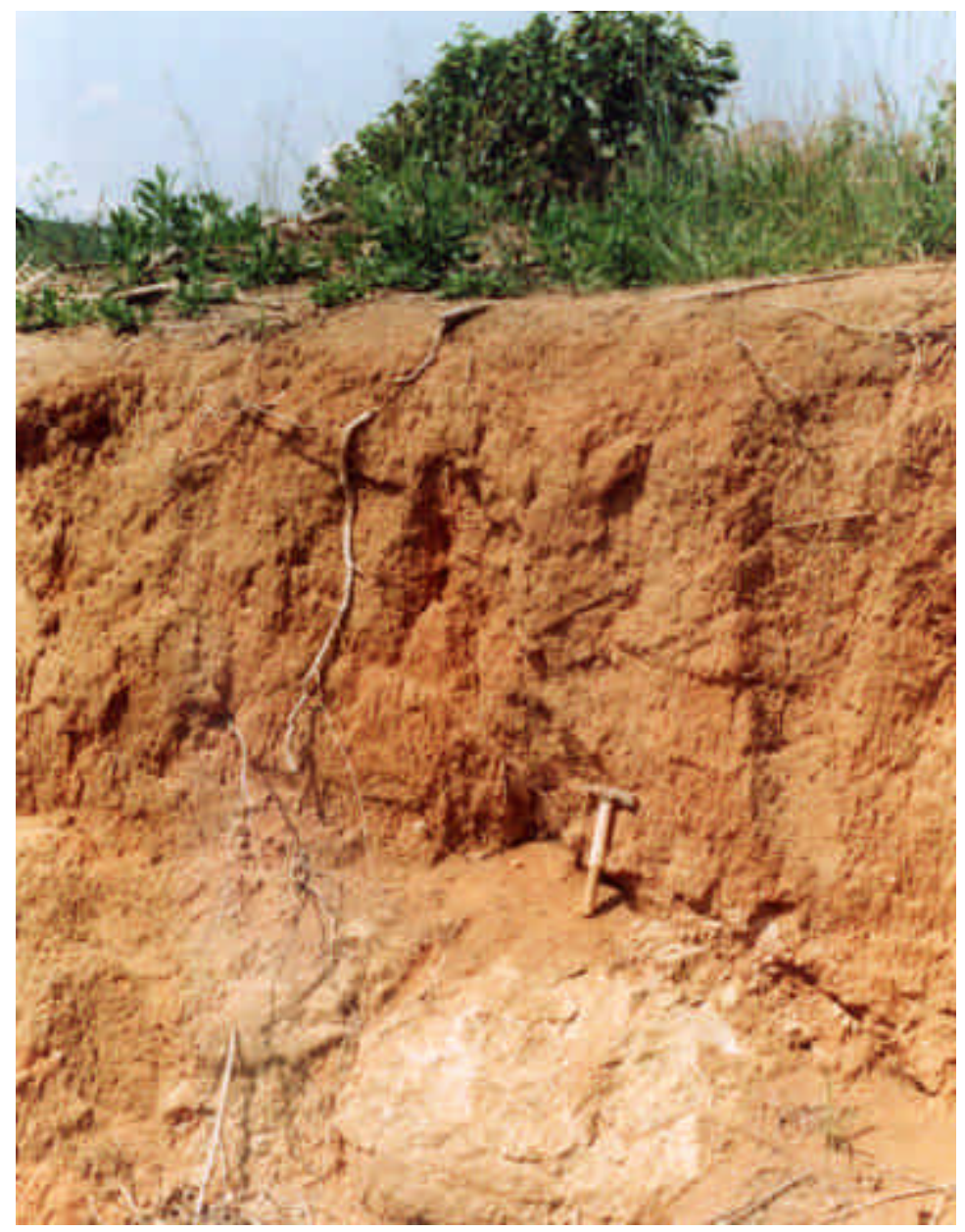

FIGURA 5.22 - Materiais inconsolidados pertencentes a Sub-unidade 13b.

TABELA 5.22 - Caracterização das amostras dos materiais inconsolidados que compõem a Unidade 13 quanto a sua localização, granulometria e índices físicos.

\begin{tabular}{|l|c|c|c|c|c|c|c|c|c|c|}
\hline \multirow{2}{*}{ Amostra } & \multirow{2}{*}{$\begin{array}{c}\text { UTM } \\
(\mathbf{E}-\mathbf{W})\end{array}$} & \multirow{2}{*}{$\begin{array}{c}\text { UTM } \\
(\mathbf{N}-\mathbf{S})\end{array}$} & $\begin{array}{c}\text { Argila } \\
(\boldsymbol{\%})\end{array}$ & $\begin{array}{c}\text { Silte } \\
(\boldsymbol{\%})\end{array}$ & $\begin{array}{c}\text { Areia } \\
(\boldsymbol{\%})\end{array}$ & $\begin{array}{c}\mathbf{p}_{\mathbf{s}} \\
\left(\mathbf{g} / \mathbf{c m}^{\mathbf{3}}\right)\end{array}$ & $\begin{array}{c}\mathbf{\rho}_{\mathbf{d}} \\
\left(\mathbf{g} / \mathbf{c m}^{3}\right)\end{array}$ & $\mathbf{e}$ & $\mathbf{n}(\boldsymbol{\%})$ & $\mathbf{S r}(\boldsymbol{\%})$ \\
\hline P019-A15 & 342654 & 7608614 & 49 & 21 & 30 & 2,654 & & & & \\
\hline P021-A17 & 343039 & 7607286 & 51 & 18 & 31 & 2,616 & 0,997 & 1,62 & 61,89 & 63,21 \\
\hline P025-A18 & 341484 & 7607181 & 51 & 12 & 37 & 2,696 & 1,211 & 1,23 & 55,08 & 76,56 \\
\hline P053-A31 & 331083 & 7603883 & 56 & 15 & 29 & 2,672 & 1,183 & 1,26 & 55,74 & 43,04 \\
\hline P067-A38 & 334199 & 7606042 & 60 & 13 & 27 & 2,64 & & & & \\
\hline
\end{tabular}


TABELA 5.23 - Caracterização das amostras dos materiais inconsolidados que compõem a Unidade 13 qua nto a sua localização, granulometria e índices físicos.

\begin{tabular}{|l|c|c|c|c|c|c|c|c|}
\hline Amostra & $\begin{array}{c}\text { C.T.C. } \\
\text { do Solo } \\
(\mathbf{C m o l} / \mathbf{k g})\end{array}$ & $\begin{array}{c}\text { C.T.C. } \\
\mathbf{d a} \text { Argila } \\
(\mathbf{C m o l} / \mathbf{k g})\end{array}$ & $\begin{array}{c}\text { S.E. } \\
\mathbf{d o S o l o} \\
\left(\mathbf{m}^{\mathbf{2}} \mathbf{/ g}\right)\end{array}$ & $\begin{array}{c}\text { Vb } \\
(\mathbf{g} / \mathbf{1 0 0 g} \text { de solo })\end{array}$ & $\begin{array}{c}\text { Comportamento } \\
\text { Laterítico }\end{array}$ & $\begin{array}{c}\text { Potencial } \\
\text { Expansivo }\end{array}$ & $\begin{array}{c}\text { Acb } \\
(\mathbf{g} / \mathbf{1 0 0 g} \text { de argila) }\end{array}$ & Atividade \\
\hline P019-A15 & 3,6 & 7,35 & 27,93 & 1,14 & Sim & Muito Baixo & 2,33 & Argila Inativa \\
\hline P021-A17 & 4,3 & 8,43 & 33,69 & 1,38 & Sim & Muito Baixo & 2,7 & Argila Inativa \\
\hline P025-A18 & 4,9 & 9,61 & 38,25 & 1,57 & Não & Muito Baixo & 3,07 & Pouco Ativa \\
\hline P053-A31 & 4,4 & 7,86 & 34,3 & 1,4 & Sim & Muito Baixo & 2,5 & Argila Inativa \\
\hline P067-A38 & 6,2 & 10,33 & 48,78 & 1,99 & Não & Muito Baixo & 3,32 & Pouco Ativa \\
\hline
\end{tabular}

TABELA 5.24 - Caracterização das amostras dos materiais inconsolidados que compõem a Unidade 15 quanto a sua localização, granulometria e índices físicos.

\begin{tabular}{|c|c|c|c|c|c|c|}
\hline \multirow{2}{*}{ Amostra } & \multirow{2}{*}{$\begin{array}{c}\text { UTM } \\
(\mathbf{E}-\mathbf{W})\end{array}$} & \multirow{2}{*}{$\begin{array}{l}\text { UTM } \\
\text { (N-S) }\end{array}$} & \multicolumn{3}{|c|}{ Textura } & \multirow{2}{*}{$\underset{\left(\mathrm{g} / \mathrm{cm}^{3}\right)}{\boldsymbol{\rho}_{\mathrm{s}}}$} \\
\hline & & & \begin{tabular}{|c|}
$\begin{array}{c}\text { Argila } \\
(\%)\end{array}$ \\
\end{tabular} & $\begin{array}{r}\text { Silte } \\
(\%)\end{array}$ & \begin{tabular}{|c|} 
Areia \\
$(\%)$
\end{tabular} & \\
\hline P013-A08 & 324261 & 7596274 & 9 & 47 & 44 & 2,671 \\
\hline P017-A12 & 342643 & 7597482 & 17 & 48 & 35 & 2,71 \\
\hline P114-A45 & 345397 & 7598394 & 16 & 41 & 43 & 2,726 \\
\hline
\end{tabular}

TABELA 5.25 - Caracterização das amostras dos materiais inconsolidados que compõem a Unidade 15 pelo método de adsorção de azul de metileno.

\begin{tabular}{|l|c|c|c|c|c|c|c|c|}
\hline Amostra & $\begin{array}{c}\text { C.T.C. } \\
\text { do Solo } \\
(\mathbf{C m o l} / \mathbf{k g})\end{array}$ & $\begin{array}{c}\text { C.T.C. } \\
\text { da Argila } \\
(\mathbf{C m o l} / \mathbf{k g})\end{array}$ & $\begin{array}{c}\text { S.E. } \\
\mathbf{d o} \text { Solo } \\
\left(\mathbf{m}^{\mathbf{2}} / \mathbf{g}\right)\end{array}$ & $\begin{array}{c}\text { Vb } \\
(\mathbf{g} / \mathbf{1 0 0 g} \text { de solo })\end{array}$ & $\begin{array}{c}\text { Comportamento } \\
\text { Laterítico }\end{array}$ & $\begin{array}{c}\text { Potencial } \\
\text { Expansivo }\end{array}$ & $\begin{array}{c}\text { Acb } \\
(\mathbf{g} / \mathbf{1 0 0 g} \text { de argila) }\end{array}$ & Atividade \\
\hline P013-A08 & 4,6 & 51,11 & 35,96 & 1,47 & Sim & Muito Baixo & 16,33 & Muito Ativa \\
\hline P017-A12 & 3,3 & 19,41 & 25,61 & 1,05 & Sim & Muito Baixo & 6,16 & Normal \\
\hline P114-A45 & 21,3 & 133,13 & 167 & 6,83 & Não & Baixo & 42,66 & Nociva \\
\hline
\end{tabular}

\section{Unidade 16}

Materiais residuais de migmatitos graníticos e estromatíticos pertencentes ao grupo textural III (Tabela 5.26) com espessuras variando de 1,5 a 3,0 m (16a) e superiores a 3,0 m podendo atingir até 3,5 m. A unidade 16 se estende por uma área de $34,62 \mathrm{~km}^{2}$ (7,18\% do total). 
TABELA 5.26 - Caracterização das amostras dos materiais inconsolidados que compõem a Unidade 16 quanto a sua localização, granulometria e índices físicos.

\begin{tabular}{|c|c|c|c|c|c|c|c|c|c|c|}
\hline \multirow[b]{2}{*}{ Amostra } & \multirow{2}{*}{$\begin{array}{c}\text { UTM } \\
(\mathbf{E}-\mathbf{W})\end{array}$} & \multirow{2}{*}{$\begin{array}{l}\text { UTM } \\
\text { (N-S) }\end{array}$} & \multicolumn{3}{|c|}{ Textura } & \multirow{2}{*}{$\underset{\left(\mathrm{g} / \mathrm{cm}^{3}\right)}{\boldsymbol{p}_{\mathrm{s}}}$} & \multirow{2}{*}{$\underset{\left(\mathrm{g} / \mathrm{cm}^{3}\right)}{\rho_{\mathrm{d}}}$} & \multirow[b]{2}{*}{ e } & \multirow[b]{2}{*}{$\mathrm{n}(\%)$} & \multirow[b]{2}{*}{$\operatorname{Sr}(\%)$} \\
\hline & & & \begin{tabular}{|c|} 
Argila \\
$(\%)$ \\
\end{tabular} & $\begin{array}{l}\text { Silte } \\
(\%)\end{array}$ & \begin{tabular}{|c|} 
Areia \\
$(\%)$
\end{tabular} & & & & & \\
\hline P014-A10 & 345397 & 7598394 & 37 & 26 & 37 & 2,629 & & & & \\
\hline P028-A19 & 339923 & 7611342 & 39 & 35 & 26 & 2,773 & 1,32 & 1,08 & 51,98 & 57,8 \\
\hline P031-A21 & 339016 & 7612972 & 27 & 35 & 38 & 2,711 & 1,285 & 1,11 & 52,58 & 78,81 \\
\hline P054-A32 & 331765 & 7606820 & 35 & 26 & 39 & 2,658 & 1,1 & 1,42 & 58,61 & 35,24 \\
\hline P057-A34 & 328031 & 7606069 & 42 & 27 & 31 & 2,651 & 1,228 & 1,16 & 53,67 & 44,59 \\
\hline P068-A39 & 333888 & 7607528 & 39 & 35 & 26 & 2,685 & 1,103 & 1,43 & 58,92 & 36,87 \\
\hline
\end{tabular}

De acordo com os resultados mostrados na Tabela 5.27, a unidade 16 possui potencial expansivo muito baixo e comportamento relacionado a atividade das argilas variando de pouco ativo a normal.

\section{Unidade 17}

É formada por materiais residuais de migmatitos graníticos e estromatíticos pertencentes ao grupo textural IV (Tabela 5.28) apresentando espessuras superiores a 3,0 m. A unidade 17 ocupa uma área de 5,50 $\mathrm{km}^{2}$ (1,14\% do total).

De acordo com os resultados apontados na Tabela 5.29, a unidade 17 possui comportamento não laterítico, potencial expansivo baixo e comportamento relacionado a atividade das argilas considerado como normal.

\section{Unidade 18}

É constituída por materiais residuais de migmatitos graníticos e estromatíticos pertencentes ao grupo textural V (Tabela 5.30) com espessuras variando entre 0,5 e 1,5 m (Sub-unidade 18a). e entre 1,5 e 3,0 m (Sub-unidade 18b). A unidade 17 ocupa uma área de $15,84 \mathrm{~km}^{2}(3,28 \%$ do total).

De acordo com os resultados apontados na Tabela 5.31, a unidade 18 possui potencial expansivo baixo e comportamento relacionado a atividade das argilas variando de inativo a pouco ativo. 
TABELA 5.27 - Caracterização das amostras dos materiais inconsolidados que compõem a Unidade 16 pelo método de adsorção de azul de metileno.

\begin{tabular}{|l|c|c|c|c|c|c|c|c|}
\hline Amostra & $\begin{array}{c}\text { C.T.C. } \\
\text { do Solo } \\
(\mathbf{C m o l} / \mathbf{k g})\end{array}$ & $\begin{array}{c}\text { C.T.C. } \\
\mathbf{d a} \text { Argila } \\
(\mathbf{C m o l} / \mathbf{k g})\end{array}$ & $\begin{array}{c}\text { S.E. } \\
\mathbf{d o S o l o} \\
\left(\mathbf{m}^{\mathbf{2}} \mathbf{/ g}\right)\end{array}$ & $\begin{array}{c}\text { Vb } \\
(\mathbf{g} / \mathbf{1 0 0 g} \text { de solo })\end{array}$ & $\begin{array}{c}\text { Comportamento } \\
\text { Laterítico }\end{array}$ & $\begin{array}{c}\text { Potencial } \\
\text { Expansivo }\end{array}$ & $\begin{array}{c}\text { Acb } \\
(\mathbf{g} / \mathbf{1 0 0 g} \text { de argila) }\end{array}$ & Atividade \\
\hline P014-A10 & 5,4 & 14,59 & 42,13 & 1,72 & Não & Muito Baixo & 4,65 & Pouco Ativa \\
\hline P028-A19 & 4,5 & 11,54 & 35,1 & 1,43 & Sim & Muito Baixo & 3,68 & Pouco Ativa \\
\hline P031-A21 & 4,2 & 15,56 & 33,26 & 1,36 & Sim & Muito Baixo & 5,03 & Normal \\
\hline P057-A34 & 7,2 & 17,14 & 56,71 & 2,32 & Não & Muito Baixo & 5,52 & Normal \\
\hline P068-A39 & 5,1 & 13,08 & 40,04 & 1,64 & Não & Muito Baixo & 4,2 & Pouco Ativa \\
\hline
\end{tabular}

TABELA 5.28 - Caracterização da amostra dos materiais inconsolidados que compõem a Unidade 17 quanto a sua localização, granulometria e índices físicos.

\begin{tabular}{|c|c|c|c|c|c|c|}
\hline \multirow{2}{*}{ Amostra } & \multirow{2}{*}{$\begin{array}{c}\text { UTM } \\
(\mathbf{E}-\mathbf{W})\end{array}$} & \multirow{2}{*}{$\begin{array}{l}\text { UTM } \\
(\mathbf{N}-\mathbf{S})\end{array}$} & \multicolumn{3}{|c|}{ Textura } & \multirow{2}{*}{$\underset{\left(\mathrm{g} / \mathbf{c m}^{3}\right)}{\boldsymbol{\rho}_{\mathrm{s}}}$} \\
\hline & & & $\begin{array}{c}\text { Argila } \\
(\%)\end{array}$ & $\begin{array}{r}\text { Silte } \\
(\%)\end{array}$ & $\begin{array}{c}\begin{array}{c}\text { Areia } \\
(\%)\end{array} \\
\end{array}$ & \\
\hline P134-A59 & 336418 & 7613127 & 29 & 45 & 26 & 2,724 \\
\hline
\end{tabular}

TABELA 5.29 - Caracterização da amostra dos materiais inconsolidados que compõem a Unidade 17 pelo método de adsorção de azul de metileno.

\begin{tabular}{|c|c|c|c|c|c|c|c|c|}
\hline Amostra & $\begin{array}{c}\text { C.T.C. } \\
\text { do Solo } \\
(\mathbf{C m o l} / \mathbf{k g})\end{array}$ & $\begin{array}{c}\text { C.T.C. } \\
\text { da Argila } \\
(\mathbf{C m o l} / \mathbf{k g})\end{array}$ & $\begin{array}{c}\text { S.E. } \\
\mathbf{d o S} \text { Solo } \\
\left(\mathbf{m}^{2} / \mathbf{g}\right)\end{array}$ & $\begin{array}{c}\text { Vb } \\
(\mathbf{g} / \mathbf{1 0 0 g} \text { de solo })\end{array}$ & $\begin{array}{c}\text { Comportamento } \\
\text { Laterítico }\end{array}$ & $\begin{array}{c}\text { Potencial } \\
\text { Expansivo }\end{array}$ & $\begin{array}{c}\text { Acb } \\
(\mathbf{g} / \mathbf{1 0 0 g} \text { de argila) }\end{array}$ & Atividade \\
\hline P134-A59 & 5,4 & 18,62 & 42,52 & 1,74 & Não & Muito Baixo & 5,99 & Normal \\
\hline
\end{tabular}

TABELA 5.30 - Caracterização das amostras dos materiais inconsolidados que compõem a Unidade 18 quanto a sua localização, granulometria e índices físicos.

\begin{tabular}{|l|c|c|c|c|c|c|c|c|c|c|}
\hline \multirow{2}{*}{ Amostra } & \multirow{2}{*}{$\begin{array}{c}\text { UTM } \\
(\mathbf{E}-\mathbf{W})\end{array}$} & \multirow{2}{*}{$\begin{array}{c}\text { UTM } \\
(\mathbf{N}-\mathbf{S})\end{array}$} & $\begin{array}{c}\text { Argila } \\
(\boldsymbol{\%})\end{array}$ & $\begin{array}{c}\text { Silte } \\
(\boldsymbol{\%})\end{array}$ & $\begin{array}{c}\text { Areia } \\
(\boldsymbol{\%})\end{array}$ & $\begin{array}{c}\mathbf{\rho}_{\mathbf{s}} \\
\left(\mathbf{g} / \mathbf{c m}^{\mathbf{3}}\right)\end{array}$ & $\begin{array}{c}\mathbf{\rho}_{\mathbf{d}} \\
\left(\mathbf{g} / \mathbf{c m}^{3}\right)\end{array}$ & $\mathbf{e}$ & $\mathbf{n}(\boldsymbol{\%})$ & Sr (\%) \\
\hline P055-A33 & 330192 & 7609779 & 50 & 12 & 38 & 2,64 & 1,175 & 1,25 & 55,49 & 40,49 \\
\hline P069-A40 & 330254 & 7609137 & 58 & 11 & 31 & 2,674 & 1,236 & 1,16 & 53,76 & 53,21 \\
\hline
\end{tabular}


TABELA 5.31 - Caracterização das amostras dos materiais inconsolidados que compõem a Unidade 18 pelo método de adsorção de azul de metileno.

\begin{tabular}{|l|c|c|c|c|c|c|c|c|}
\hline Amostra & $\begin{array}{c}\text { C.T.C. } \\
\mathbf{d o s} \text { Solo } \\
(\mathbf{C m o l} / \mathbf{k g})\end{array}$ & $\begin{array}{c}\text { C.T.C. } \\
\text { da Argila } \\
(\mathbf{C m o l} / \mathbf{k g})\end{array}$ & $\begin{array}{c}\text { S.E. } \\
\text { do Solo } \\
\left(\mathbf{m}^{\mathbf{2}} / \mathbf{g}\right)\end{array}$ & $\begin{array}{c}\text { Vb } \\
(\mathbf{g} / \mathbf{1 0 0 g} \text { de solo })\end{array}$ & $\begin{array}{c}\text { Comportamento } \\
\text { Laterítico }\end{array}$ & $\begin{array}{c}\text { Potencial } \\
\text { Expansivo }\end{array}$ & $\begin{array}{c}\text { Acb } \\
(\mathbf{g} / \mathbf{1 0 0 g} \text { de argila) }\end{array}$ & Atividade \\
\hline P055-A33 & 4,2 & 8,40 & 32,68 & 1,34 & Sim & Muito Baixo & 2,67 & Argila Inativa \\
\hline P069-A40 & 7,9 & 13,62 & 61,64 & 2,52 & Não & Muito Baixo & 4,34 & Pouco Ativa \\
\hline
\end{tabular}

\section{Unidade 19}

É composta por Materiais residuais de migmatitos graníticos e estromatíticos pertencentes ao grupo textural VII (Tabela 5.32) com espessuras variando entre 1,5 e 3,0 m. A unidade 19 ocupa uma área de $5,37 \mathrm{~km}^{2}$ (1,11\% do total).

Os resultados mostrados na Tabela 5.32 revelam que a unidade 19 possui potencial expansivo baixo e comportamento relacionado a atividade das argilas variando de inativo a pouco ativo

\section{Unidade 20}

É a maior unidade de materiais inconsolidados mapeada. Estende-se por uma superfície de $123,97 \mathrm{~km}^{2}$ (25,71 \% do total). A unidade 20 é constituída por materiais residuais de migmatitos graníticos e estromatíticos pertencentes aos grupos texturais IV, V e VI (Tabela 5.34) apresentando espessuras variáveis que podem atingir até $7,0 \mathrm{~m}$.

De acordo com os resultados apontados pelas amostras de materiais inconsolidados na Tabela 5.35, na unidade 20 predomina o comportamento não laterítico. A unidade 20 possui ainda potencial expansivo baixo e comportamento relacionado a atividade das argilas variando de inativo a ativo.

\section{Unidade 21}

É constituída por materiais residuais de migmatitos oftalmíticos pertencentes ao grupo textural III (Tabela 5.36) com espessuras variando entre 1,5 e 3,0 m. A unidade 21 ocupa uma área de 5,22 $\mathrm{km}^{2}$ (1,08\% do total). 
TABELA 5.32 - Caracterização das amostras dos materiais inconsolidados que compõem a Unidade 19 quanto a sua localização, granulometria e índices físicos.

\begin{tabular}{|l|c|c|c|c|c|c|c|c|c|c|}
\hline \multirow{2}{*}{ Amostra } & \multirow{2}{*}{$\begin{array}{c}\text { UTM } \\
(\mathbf{E}-\mathbf{W})\end{array}$} & \multirow{2}{*}{$\begin{array}{c}\text { UTM } \\
(\mathbf{N}-\mathbf{S})\end{array}$} & $\begin{array}{c}\text { Argila } \\
(\boldsymbol{\%})\end{array}$ & $\begin{array}{c}\text { Silte } \\
(\boldsymbol{\%})\end{array}$ & $\begin{array}{c}\text { Areia } \\
(\boldsymbol{\%})\end{array}$ & $\begin{array}{c}\boldsymbol{\rho}_{\mathrm{s}} \\
\left(\mathbf{g} / \mathbf{c m}^{\mathbf{3}}\right)\end{array}$ & $\begin{array}{c}\mathbf{\rho}_{\mathbf{d}} \\
\left(\mathbf{g} / \mathbf{c m}^{\mathbf{3}}\right)\end{array}$ & $\mathbf{E}$ & $\mathbf{n}(\boldsymbol{\%})$ & $\mathbf{S r}(\boldsymbol{\%})$ \\
\hline P070-A41 & 340098 & 7596080 & 56 & 27 & 17 & 2,71 & 1,077 & 1,52 & 60,27 & 60,52 \\
\hline P123-A51 & 346902 & 7599255 & 44 & 39 & 17 & 2,745 & & & & \\
\hline
\end{tabular}

TABELA 5.33 - Caracterização das amostras dos materiais inconsolidados que compõem a Unidade 19 pelo método de adsorção de azul de metileno.

\begin{tabular}{|l|c|c|c|c|c|c|c|c|}
\hline Amostra & $\begin{array}{c}\text { C.T.C. } \\
\text { Do Solo } \\
(\mathbf{C m o l} / \mathbf{k g})\end{array}$ & $\begin{array}{c}\text { C.T.C. } \\
\text { da Argila } \\
(\mathbf{C m o l} / \mathbf{k g})\end{array}$ & $\begin{array}{c}\text { S.E. } \\
\text { do Solo } \\
\left(\mathbf{m}^{\mathbf{2}} \mathbf{g}\right)\end{array}$ & $\begin{array}{c}\text { Vb } \\
(\mathbf{g} / \mathbf{1 0 0 g} \text { de solo })\end{array}$ & $\begin{array}{c}\text { Comportamento } \\
\text { Laterítico }\end{array}$ & $\begin{array}{c}\text { Potencial } \\
\text { Expansivo }\end{array}$ & $\begin{array}{c}\text { Acb } \\
(\mathbf{g} / \mathbf{1 0 0 g} \text { de argila })\end{array}$ & Atividade \\
\hline P070-A41 & 4,6 & 8,21 & 35,82 & 1,46 & Sim & Muito Baixo & 2,61 & Argila Inativa \\
\hline P123-A51 & 5,3 & 12,04 & 61,49 & 1,69 & Não & Muito Baixo & 3,85 & Pouco Ativa \\
\hline
\end{tabular}

TABELA 5.34 - Caracterização das amostras dos materiais inconsolidados que compõem a Unidade 20 quanto a sua localização, granulometria e índices físicos.

\begin{tabular}{|c|c|c|c|c|c|c|c|c|c|c|}
\hline \multirow[b]{2}{*}{ Amostra } & \multirow{2}{*}{$\begin{array}{c}\text { UTM } \\
(\mathbf{E}-\mathbf{W})\end{array}$} & \multirow{2}{*}{$\begin{array}{l}\text { UTM } \\
\text { (N-S) }\end{array}$} & \multicolumn{3}{|c|}{ Textura } & \multirow{2}{*}{$\underset{\left(\mathrm{g} / \mathrm{cm}^{3}\right)}{\boldsymbol{\rho}_{\mathrm{s}}}$} & \multirow[b]{2}{*}{$\underset{\left(\mathbf{g} / \mathrm{cm}^{3}\right)}{\boldsymbol{\rho}_{\mathbf{d}}}$} & \multirow[b]{2}{*}{ e } & \multirow[b]{2}{*}{$\mathrm{n}(\%)$} & \multirow[b]{2}{*}{$\operatorname{Sr}(\%)$} \\
\hline & & & \begin{tabular}{|c|}
$\begin{array}{c}\text { Argila } \\
(\%)\end{array}$ \\
\end{tabular} & $\begin{array}{l}\text { Silte } \\
(\%)\end{array}$ & \begin{tabular}{|c|}
$\begin{array}{c}\text { Areia } \\
(\%)\end{array}$ \\
\end{tabular} & & & & & \\
\hline $\mathrm{P} 126-\mathrm{A} 52$ & 346902 & 7599255 & 62 & 18 & 20 & 2,745 & & & & \\
\hline P127-A53 & 349321 & 7601633 & 54 & 11 & 35 & 2,647 & 1,16 & 1,28 & 56,19 & 40,63 \\
\hline P129-A54 & 353473 & 7602603 & 29 & 52 & 19 & 2,797 & & & & \\
\hline P130-A55 & 354800 & 7604478 & 38 & 12 & 50 & 2,727 & & & & \\
\hline P131-A56 & 356105 & 7606346 & 57 & 11 & 32 & 2,665 & 1,051 & 1,54 & 60,57 & 40,11 \\
\hline P132-A57 & 358666 & 7605908 & 39 & 17 & 44 & 2,783 & & & & \\
\hline P133-A58 & 349904 & 7605752 & 57 & 15 & 28 & 2,927 & 0,964 & 2,04 & 67,08 & 34,6 \\
\hline
\end{tabular}

De acordo com os resultados apontados pelas amostras de materiais inconsolidados na Tabela 5.37, a unidade 21 possui comportamento não laterítico, potencial expansivo baixo e comportamento relacionado a atividade das argilas considerado normal. 
TABELA 5.35 - Caracterização das amostras dos materiais inconsolidados que compõem a Unidade 20 pelo método de adsorção de azul de metileno.

\begin{tabular}{|l|c|c|c|c|c|c|c|c|}
\hline Amostra & $\begin{array}{c}\text { C.T.C. } \\
\text { Do Solo } \\
(\mathbf{C m o l} / \mathbf{k g})\end{array}$ & $\begin{array}{c}\text { C.T.C. } \\
\mathbf{d a} \text { Argila } \\
(\mathbf{C m o l} / \mathbf{k g})\end{array}$ & $\begin{array}{c}\text { S.E. } \\
\mathbf{d o \text { Solo }} \\
\left(\mathbf{m}^{\mathbf{2}} \mathbf{g}\right)\end{array}$ & $\begin{array}{c}\text { Vb } \\
(\mathbf{g} / \mathbf{1 0 0 g} \text { de solo })\end{array}$ & $\begin{array}{c}\text { Comportamento } \\
\text { Laterítico }\end{array}$ & $\begin{array}{c}\text { Potencial } \\
\text { Expansivo }\end{array}$ & $\begin{array}{c}\text { Acb } \\
(\mathbf{g} / \mathbf{1 0 0 g} \text { de argila) }\end{array}$ & Atividade \\
\hline P126-A52 & 7,9 & 12,74 & 61,49 & 2,51 & Não & Muito Baixo & 4,05 & Pouco Ativa \\
\hline P127-A53 & 4,6 & 8,52 & 36,14 & 1,48 & Sim & Muito Baixo & 2,74 & Argila Inativa \\
\hline P129-A54 & 9,7 & 33,45 & 76,17 & 3,11 & Não & Muito Baixo & 10,74 & Ativa \\
\hline P130-A55 & 3,5 & 9,21 & 27,33 & 1,12 & Sim & Muito Baixo & 2,94 & Argila Inativa \\
\hline P131-A56 & 6,1 & 10,70 & 47,72 & 1,95 & Não & Muito Baixo & 3,42 & Pouco Ativa \\
\hline P132-A57 & 5,3 & 13,59 & 41,76 & 1,71 & Não & Muito Baixo & 4,74 & Pouco Ativa \\
\hline P133-A58 & 6,8 & 11,93 & 52,91 & 2,16 & Não & Muito Baixo & 3,79 & Pouco Ativa \\
\hline
\end{tabular}

TABELA 5.36 - Caracterização da amostra dos materiais inconsolidados que compõem a Unidade 21 quanto a sua localização, granulometria e índices físicos.

\begin{tabular}{|c|c|c|c|c|c|c|}
\hline \multirow[b]{2}{*}{ Amostra } & \multirow{2}{*}{$\begin{array}{c}\text { UTM } \\
(\mathbf{E}-\mathbf{W})\end{array}$} & \multirow{2}{*}{$\begin{array}{c}\text { UTM } \\
(\mathbf{N}-S)\end{array}$} & \multicolumn{3}{|c|}{ Textura } & \multirow{2}{*}{$\underset{\left(\mathbf{g} / \mathbf{c m}^{3}\right)}{\boldsymbol{\rho}_{\mathrm{s}}}$} \\
\hline & & & \begin{tabular}{|c} 
Argila \\
$(\%)$
\end{tabular} & $\begin{array}{l}\text { Silte } \\
(\%)\end{array}$ & \begin{tabular}{|c} 
Areia \\
$(\%)$
\end{tabular} & \\
\hline P058-A35 & 327979 & 7608423 & 32 & 28 & 40 & 2,68 \\
\hline
\end{tabular}

TABELA 5.37 - Caracterização da amostra dos materiais inconsolidados que compõem a Unidade 21 pelo método de adsorção de azul de metileno.

\begin{tabular}{|c|c|c|c|c|c|c|c|c|}
\hline Amostra & $\begin{array}{c}\text { C.T.C. } \\
\text { Do Solo } \\
(\mathbf{C m o l} / \mathbf{k g})\end{array}$ & $\begin{array}{c}\text { C.T.C. } \\
\text { da Argila } \\
(\mathbf{C m o l} / \mathbf{k g})\end{array}$ & $\begin{array}{c}\text { S.E. } \\
\text { do Solo } \\
\left(\mathbf{m}^{2} / \mathbf{g}\right)\end{array}$ & $\begin{array}{c}\text { Vb } \\
(\mathbf{g} / \mathbf{1 0 0 g} \text { de solo })\end{array}$ & $\begin{array}{c}\text { Comportamento } \\
\text { Laterítico }\end{array}$ & $\begin{array}{c}\text { Potencial } \\
\text { Expansivo }\end{array}$ & $\begin{array}{c}\text { Acb } \\
(\mathbf{g} / \mathbf{1 0 0 g} \text { de argila) }\end{array}$ & Atividade \\
\hline P058-A35 & 5,9 & 18,44 & 45,83 & 1,87 & Não & Muito Baixo & 5,85 & Normal \\
\hline
\end{tabular}

\subsubsection{Mapa de Landforms}

O mapa de landforms (ANEXO V) de acordo com Lollo (1996), representa uma forma de zoneamento do meio físico que utiliza a técnica de avaliação de terreno e que consegue associar suas unidades de formas de relevo em função do substrato rochoso e dos materiais inconsolidados presentes 
A técnica funciona a partir do conceito operacional de landform que de acordo com autor é definido como: "porção do terreno originada de processos naturais e distinguível das porções vizinhas (demais landforms) em pelo menos um dos seguintes elementos de identificação: forma e posição topográfica, frequiência e organização dos canais, inclinação das vertentes e amplitude de relevo".

A técnica de avaliação de terreno permite a divisão de uma determinada área em até três níveis hierárquicos (Figura 5.23) de acordo com a escala do método de sensoriamento remoto disponível e da finalidade pretendidas (Tabela 5.38).

Contudo, especificamente para a nosso objeto de estudo, tanto em função da escala do método de sensoriamento remoto empregado (fotografias aéreas na escala 1:60.000), quanto da finalidade principal do trabalho (subsidiar o planejamento regional), os níveis hierárquicos obtidos foram os dois níveis principais.

Assim foram delimitados quatro sistemas de terreno (Figura 5.24) subdivididos em trinta e uma unidades (ver critérios utilizados na Tabela 5.39), os quais serão descritos a seguir.

\section{SISTEMA A}

Associação de formas com ampla diversidade (colinas, vales, morros e escarpas) e que constituem a porção mais rebaixada da área em estudo. Apresenta substrato rochoso formado por litologias pré-cambrianas do Complexo Varginha onde praticamente todas suas unidades são exclusivamente constituídas de migmatitos graníticos e estromatíticos (excluindo-se a unidade A10 e parte da unidade A08). Com relação aos materiais inconsolidados, são em sua quase totalidade residua is onde predomina a classe textural III. Espessuras superiores a 1,5 m ocorrem em todas as unidades. Sua distribuição areal é de $262,44 \mathrm{~km}^{2}$ o que perfaz mais da metade da área estudada com 54,41\% do seu total (Figura 5.25).

Unidade A01 - Corresponde a colinas com topos arredondados, encostas côncavas, declividades médias e amplitudes de relevo baixas. Apresenta materiais inconsolidados do grupo textural $\mathrm{V}$ que tem sua espessura variando entre 1,5 e 3,0 m. Ocupa uma superfície de $4,56 \mathrm{~km}^{2}(0,95 \%$ do total). 


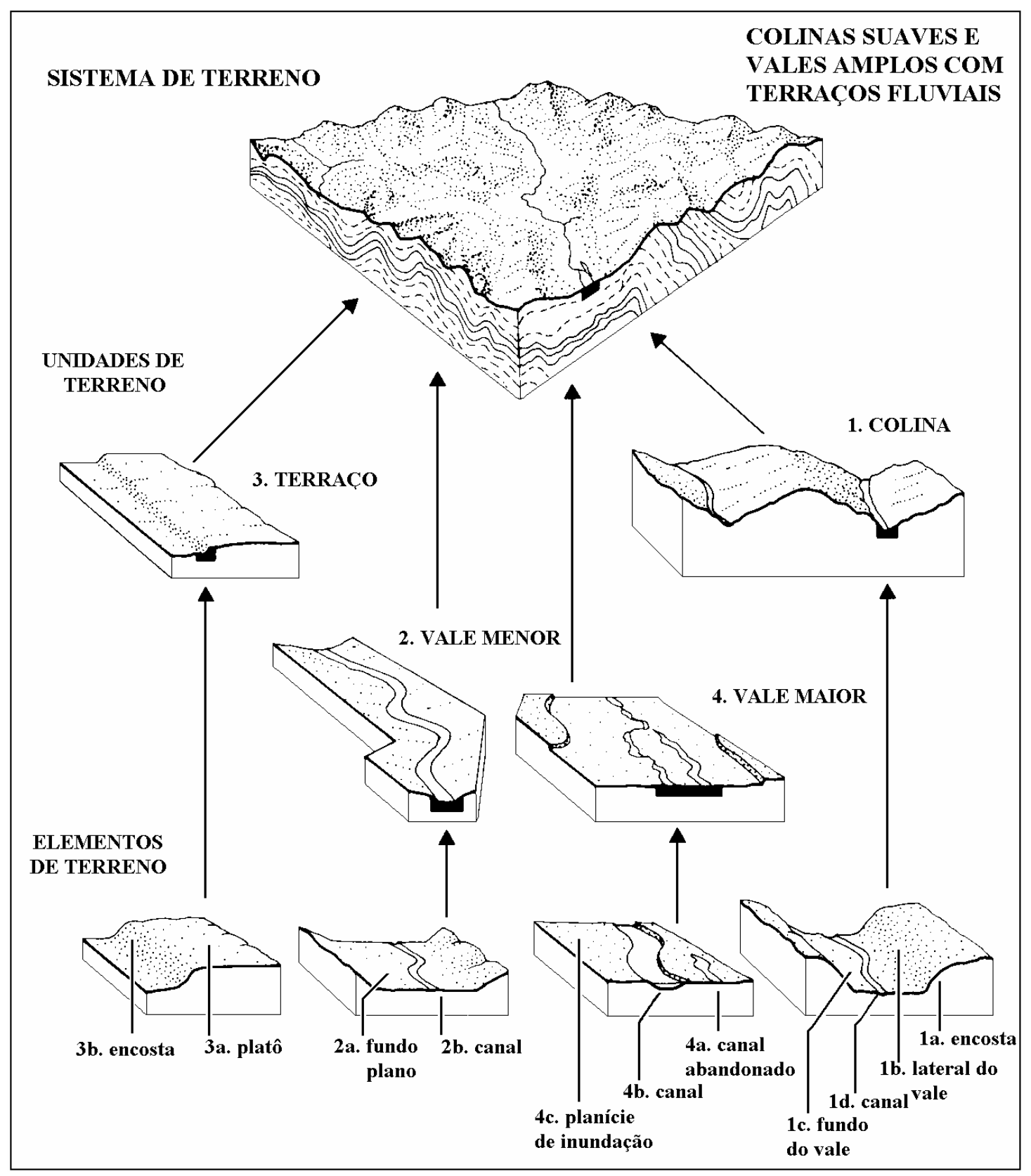

FIGURA 5.23 - Aplicação da técnica de avaliação de terreno, modificado de Cooke \& Doorkamp (1990) apud Lollo (1996). 
TABELA 5.38 - Níveis hierárquicos propostos por Lollo (1996) para técnica de avaliação de terreno.

\begin{tabular}{|c|c|c|}
\hline Nível Hierárquico & Descrição & Forma de Obtenção \\
\hline $\begin{array}{l}\text { Sistema de Terreno } \\
\text { (Land System })\end{array}$ & $\begin{array}{l}\text { Associação de feições de relevo } \\
\text { com expressão espacial } \\
\text { determinada e que representa } \\
\text { condições similares de processos } \\
\text { evolutivos e de materiais } \\
\text { rochosos associados. }\end{array}$ & $\begin{array}{l}\text { Trabalhos } \\
\text { aerofotointerpretação (sistemática } \\
\text { de reconhecimento } \\
\text { aldentificação de características } \\
\text { dos terrenos) visando um } \\
\text { reconhecimento geral da área } \\
\text { baseado nas grandes expressões } \\
\text { geomorfológicas observadas. }\end{array}$ \\
\hline $\begin{array}{c}\text { Unidade de } \\
\text { Terreno (Land } \\
\text { Unit) }\end{array}$ & $\begin{array}{l}\text { Feição individual do relevo que } \\
\text { se distingue das demais às quais } \\
\text { está associada por indicar um } \\
\text { determinado subconjunto de } \\
\text { processos do sistema de terreno } \\
\text { no qual se situa, sendo que estas } \\
\text { diferenças devem se refletir em } \\
\text { termos dos materiais } \\
\text { inconsolidados associados à } \\
\text { unidade. }\end{array}$ & $\begin{array}{l}\text { Características geomorfológicas } \\
\text { tais como forma topográfica, } \\
\text { amplitude de relevo, inclinação } \\
\text { de vertentes e características de } \\
\text { organização da drenagem em } \\
\text { termos de freqüência e } \\
\text { estruturação dos canais. }\end{array}$ \\
\hline $\begin{array}{l}\text { Elemento de } \\
\text { Terreno (Land } \\
\text { Element) }\end{array}$ & $\begin{array}{l}\text { Parte de uma feição individual do } \\
\text { relevo distinguível das demais } \\
\text { partes em termos de inclinação ou } \\
\text { forma da vertente, posição ou } \\
\text { forma topográfica, que deve } \\
\text { refletir condições diferenciadas } \\
\text { de materiais inconsolidados em } \\
\text { termos de sua espessura ou de } \\
\text { variações laterais no perfil de } \\
\text { alteração dos materiais } \\
\text { inconsolidados. }\end{array}$ & $\begin{array}{l}\text { É o mesmo usado para unidade de } \\
\text { terreno, apenas considerando-se o } \\
\text { maior nível de detalhe requerido } \\
\text { e o possível uso do enfoque } \\
\text { paramétrico para a distinção de } \\
\text { certas características do landform, } \\
\text { além da necessidade do processo } \\
\text { denominado fotodedução } \\
\text { (associação das informaçôes } \\
\text { coletadas com o conhecimento do } \\
\text { intérprete sobre o Terreno e os } \\
\text { materiais nele presentes, } \\
\text { permitindo a obtenção de } \\
\text { informações derivadas - não } \\
\text { obtidas diretamente da foto } \\
\text { aérea). }\end{array}$ \\
\hline
\end{tabular}




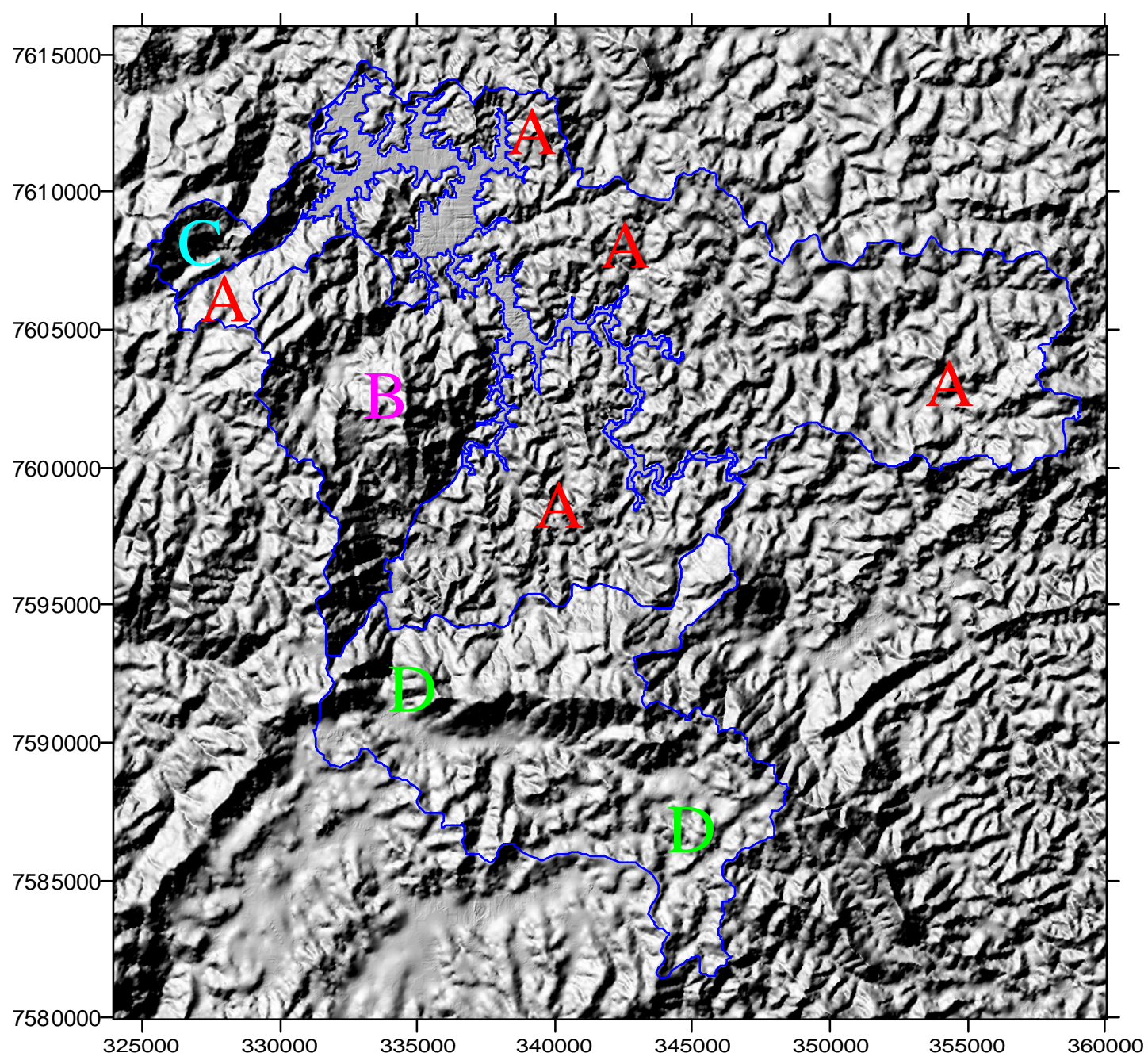

FIGURA 5.24 - Imagem sombreada do relevo (gerada a partir do MDT no Surfer ${ }^{\circledR}$ 7.00) mostrando a localização dos Sistemas de terreno que compõem a área estudada.

Unidade A02 - Estende-se por 4,19 $\mathrm{km}^{2}$ (0,87 \% do total). Caracteriza-se por apresentar morros com topos angulosos, encostas retilíneas, declividades altas, amplitudes de relevo médias e padrão de drenagem paralelo com altas densidades. Seus materiais inconsolidados pertencem ao grupo textural III. A porção ocidental exibe espessuras que variam entre 1,5 a 3,0 m e ocupa cerca de $61,10 \%$ da unidade. O setor oriental, por sua vez, apresenta espessuras de até 5,6 m que se estendem por $38,90 \%$ da unidade. 
TABELA 5.39 - Critérios Utilizados na Descrição das Unidades te Terreno.

\begin{tabular}{|c|c|c|}
\hline \multicolumn{3}{|c|}{ CRITÉRIOS UTILIZADOS NA DESCRIÇÃO DAS UNIDADES TE TERRENO } \\
\hline Significado & \begin{tabular}{|c|} 
Termo \\
\end{tabular} & Dimensão ou Descrição \\
\hline \multirow{3}{*}{ Forma do Topo } & Plano & \\
\hline & Arredondado & \\
\hline & Anguloso & \\
\hline \multirow{3}{*}{ Forma da Encosta } & Convexa & \\
\hline & Retilínea & \\
\hline & Côncava & \\
\hline \multirow{3}{*}{ Declividade } & Baixa & $<5 \%$ \\
\hline & Média & 5 a $20 \%$ \\
\hline & Alta & $>20 \%$ \\
\hline \multirow{3}{*}{ Amplitude de Relevo } & Baixa & $<100 \mathrm{~m}$ \\
\hline & Média & 100 a $300 \mathrm{~m}$ \\
\hline & Alta & $>300 \mathrm{~m}$ \\
\hline \multirow{2}{*}{ Forma dos Vale } & Aberto & \\
\hline & Fechado & \\
\hline Padrão de Drenagem & Definido por Howard (1967) & \\
\hline \multirow{3}{*}{ Frequencia de Canais } & Baixa & $<3$ canais $/ \mathrm{km}^{2}$ \\
\hline & Média & 3 a 15 canais $/ \mathrm{km}^{2}$ \\
\hline & Alta & $>15$ canais $/ \mathrm{km}^{2}$ \\
\hline
\end{tabular}

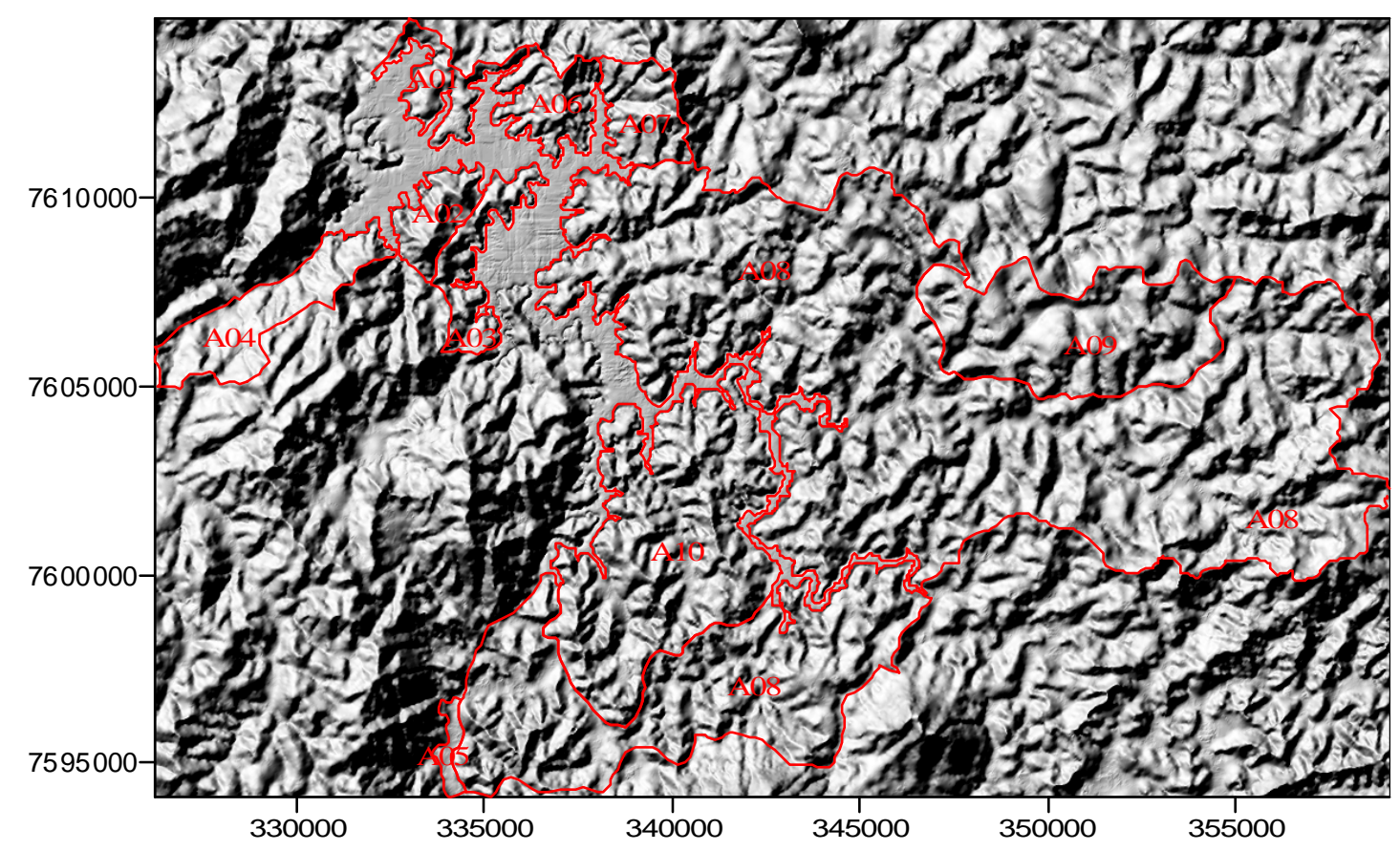

FIGURA 5.25 - Imagem sombreada do relevo mostrando a localização das unidades que compõem o Sistema de Terreno A. 


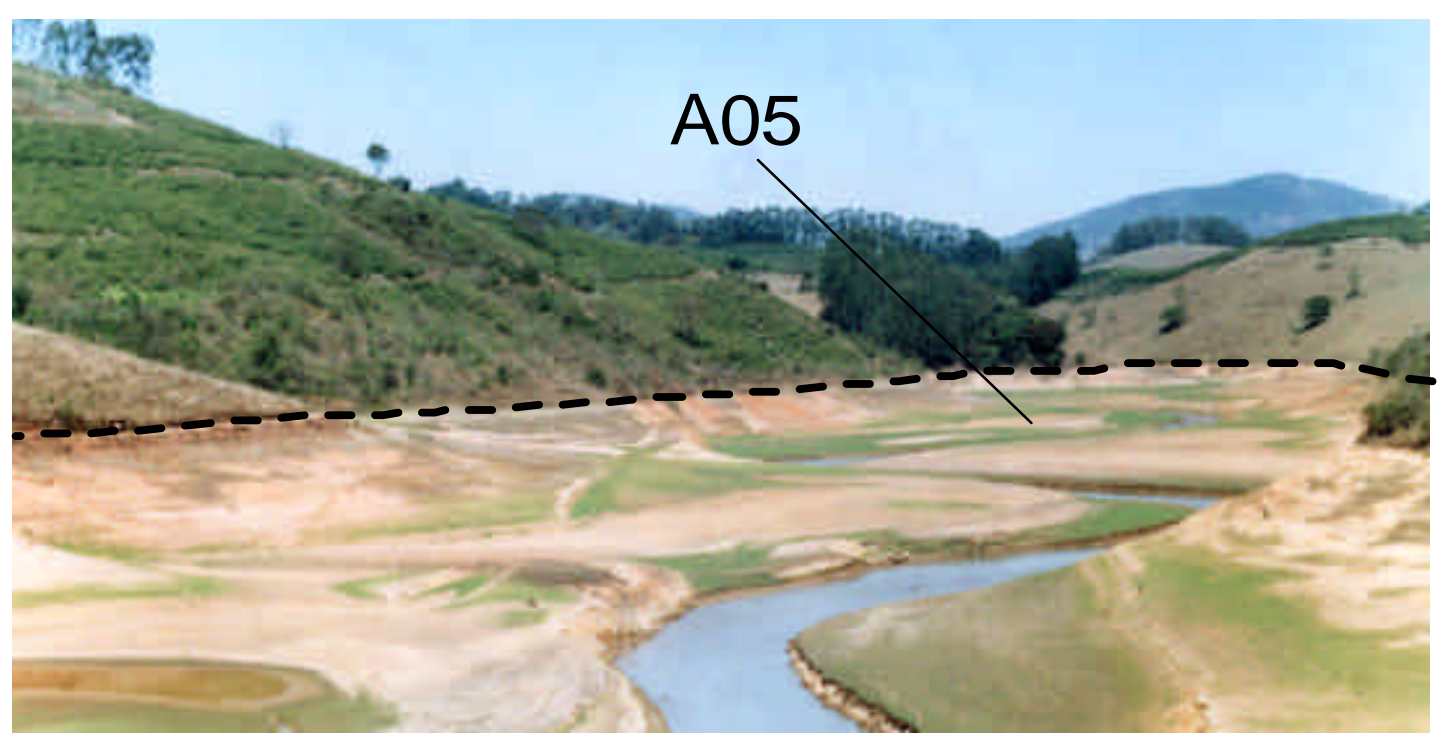

FIGURA 5.26 - Vista da Unidade A05.

Unidade A03 - Corresponde a colinas com topos arredondados, encostas retilíneas, altas declividades, amplitudes de relevo baixas, padrão de drenagem paralelo com baixas densidades. Ocupa 5,31 $\mathrm{km}^{2}(1,10 \%$ do total). Materiais inconsolidados do grupo textural III com de até 5,6 m de espessura constituem essa unidade.

Unidade A04 - Caracteriza-se por apresentar escarpas com topos retilíneos, encostas retilíneas, declividades altas, amplitudes de relevo médias e padrão de drenagem paralelo com médias densidades de canais. Apresenta materiais inconsolidados da classe textural III com espessuras variando entre 1,5 e 3,0 m. A unidade ocupa 9,18 $\mathrm{km}^{2}(1,90 \%$ do total).

Unidade A05 - É a menor unidade de terreno mapeada, ocupando apenas $1,12 \mathrm{~km}^{2}$ $(0,23 \%$ do total). Corresponde a vales abertos, encostas côncavas, declividades baixas, baixas amplitudes de relevo e densidade de canais (Figura 5.26). Seus materiais inconsolidados, ao contrário dos outros membros desse sistema, são retrabalhados do tipo aluvionar. Sua classe textural pertence ao grupo I (ver seção 5.1.5) com suas espessuras variando bastante, desde inferiores a $0,5 \mathrm{~m}$ a até 4,0 $\mathrm{m}$. 
Unidade A06 - É formada por morros com topos angulosos, encostas retilíneas, declividades altas, amplitudes de relevo médias e padrão de drenagem paralelo com altas densidades de canais. Ocupa $5,50 \mathrm{~km}^{2}$ (1,14\% do total). É constituída por materiais do grupo textural IV com espessuras superiores a 3,1 m.

Unidade A07 - Corresponde a escarpas com topos e encostas retilíneas, médias declividades, amplitudes de relevo médias e com padrão de drenagem paralelo com baixas densidades de canais (Figura 5.27). A unidade é formada por materiais inconsolidados da classe textural III com espessuras que variam entre 1,5 e 3,0 m. Ocupa $5,44 \mathrm{~km}^{2}(1,13 \%$ do total).

Unidade A08 - É a maior unidade de terreno delimitada na área em estudo, estendendo-se por $171,00 \mathrm{~km}^{2}(35,45 \%$ do total). É formada por colinas com topos arredondados, encostas retilíneas, declividades médias, amplitudes de relevo médias e padrão de drenagem dendrítico com alta densidade (Figura 5.28). Seu substrato rochoso, além de conter migmatitos graníticos e estromatíticos (73,55\% da unidade), apresenta ainda, granulitos quartzo-feldspáticos $(17,13 \%$ da unidade) na porção noroeste e charnockitos $(9,32 \%$ da unidade) no setor centro oeste. Os materiais inconsolidados que compõe a unidade A08 são diversificados. Materiais do grupo textural I de origem coluvionar e com espessuras inferiores a 0,5 m estão presentes no setor setentrional ocupando $4,14 \%$ da unidade. $\mathrm{Na}$ porção localizada ocidentalmente ao reservatório ocorrem materiais dos grupos texturais II com espessuras variando entre 1,5 e 3,0m, materiais do grupo V com espessuras superiores a 3,0 m e materiais do grupo VII com espessuras variando entre 1,5 a 3,0 m. Tais unidades de materiais inconsolidados correspondem respectivamente a $10,76 \%, 9,33 \%$ e 3,14\% da extensão da unidade A08. O restante, cerca de 76,63\%, é ocupado pelas unidades de materiais inconsolidados de classes texturais IV, V, VI e VII com espessuras que variam desde inferiores a $0,5 \mathrm{~m}$ a até 7,0 $\mathrm{m}$. 


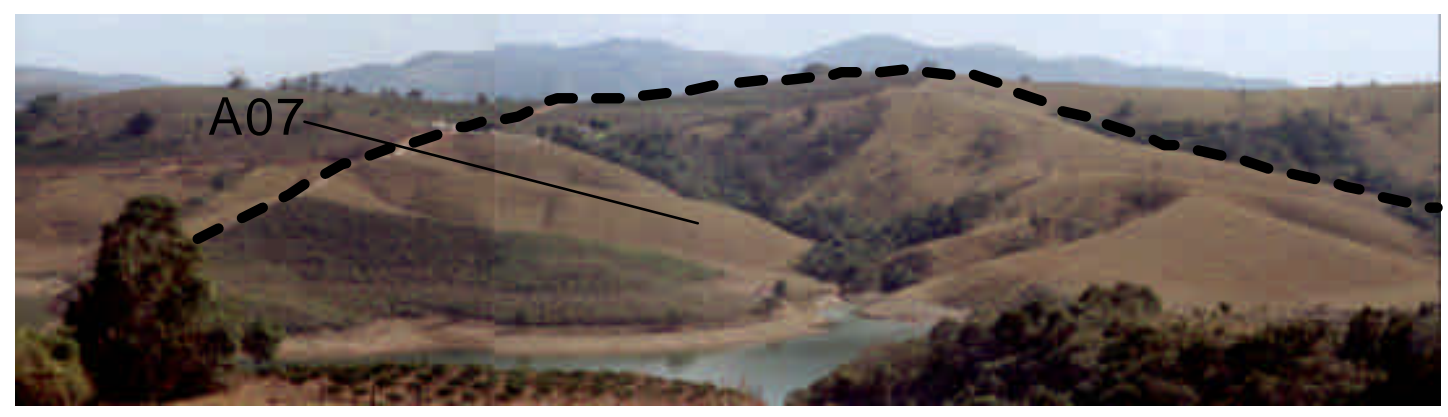

FIGURA 5.27 - Vista da Unidade A07.

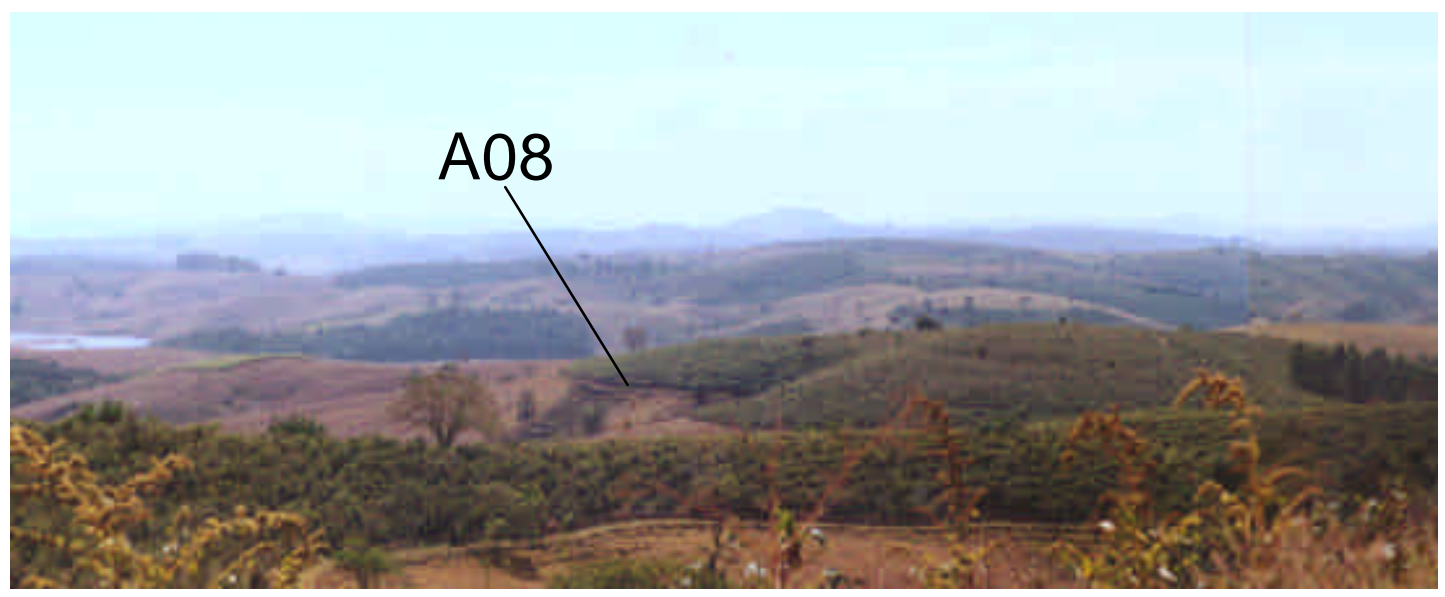

FIGURA 5.28 - Vista da Unidade A08.

Unidade A09 - Caracteriza-se por apresentar colinas com topos arredondados, encostas convexas, declividades médias, amplitudes de relevo médias com padrão de drenagem paralelo e baixa densidade de canais. Estende-se por $21,98 \mathrm{~km}^{2}(4,56 \%$ do total). Seus materiais inconsolidados, do mesmo modo que na unidade A08, apresentam classes texturais IV, V, VI e VII com espessuras que variam desde inferiores a $0,5 \mathrm{~m}$ a até superiores a até $3,2 \mathrm{~m}$.

Unidade A10 - Corresponde a morros com topos angulosos, encostas retilíneas, altas declividades, baixas amplitudes de relevo, padrão de drenagem dendrítico com média densidade de canais. Ocupa $34,17 \mathrm{~km}^{2}$ (7,09 \% do total). O substrato rochoso é formado exclusivamente por charnockitos. Seus materiais inconsolidados correspondem a classe textural III com espessuras variando entre 1,5 e 3,0 m. 


\section{SISTEMA B}

O Sistema de Terreno B (Figura 5.29) se situa no setor ocidental da área em estudo e ocupa a porção mais elevada do embasamento pré-cambriano. Estende-se por uma superfície de $76,72 \mathrm{~km}^{2}(15,91 \%$ do total) na qual estão presentes todos os padrões de forma (colinas, morros, morrotes, vales e escarpas). Seu substrato rochoso é formado exclusivamente por litologias do Complexo Varginha (migmatitos graníticos e estromatíticos, granulitos quartzo-feldspáticos e charnockitos). Seus materiais inconsolidados mais comuns pertencem a classe textural $\mathrm{V}$, que só não ocorrem nas unidades B01 e B07 do Sistema B.

Unidade B01 - Estende-se por 7,25 $\mathrm{km}^{2}$ (1,50\% do total) e é formada por escarpa com topo retilíneo, encosta côncava, declividades altas, amplitudes de relevo altas, padrões de drenagem dendríticos com média densidade de canais (Figura 5.30). Seu substrato rochoso é constituído por migmatitos graníticos e estromatíticos, apresenta materiais inconsolidados de classe textural III com espessuras variando entre 1,5 a $3,0 \mathrm{~m}$ na sua porção leste $(75,55 \%$ da unidade) e com espessuras de até 4,0 $\mathrm{m}$ na porção oeste $(23,45 \%$ da unidade).

Unidade B02 - Corresponde a colinas com topos arredondados, encostas retilíneas, altas declividades, baixas amplitudes de relevo, padrão de drenagem dendrítico com baixa densidade de canais. Migmatitos graníticos e estromatíticos formam seu substrato rochoso. Seus materiais inconsolidados são formados pela classe textural $\mathrm{V}$, com espessuras que variam entre 0,5 e 1,5 m. A Unidade B02 ocupa 4,67 km² $(0,97 \%$ do total).

Unidade B03 - Caracteriza-se por apresentar escarpas com topos e encostas retilíneas, declividades médias, amplitudes de relevo médias, padrões de drenagem dendríticos e alta densidade de canais. Seu substrato rochoso é composto por granulitos quartzo-feldspáticos. Seus materiais inconsolidados pertencem ao grupo textural V com espessuras variando entre 1,5 e 3,0 m. A Unidade B03 ocupa 12,43 $\mathrm{km}^{2}(2,58 \%$ do total $)$. 


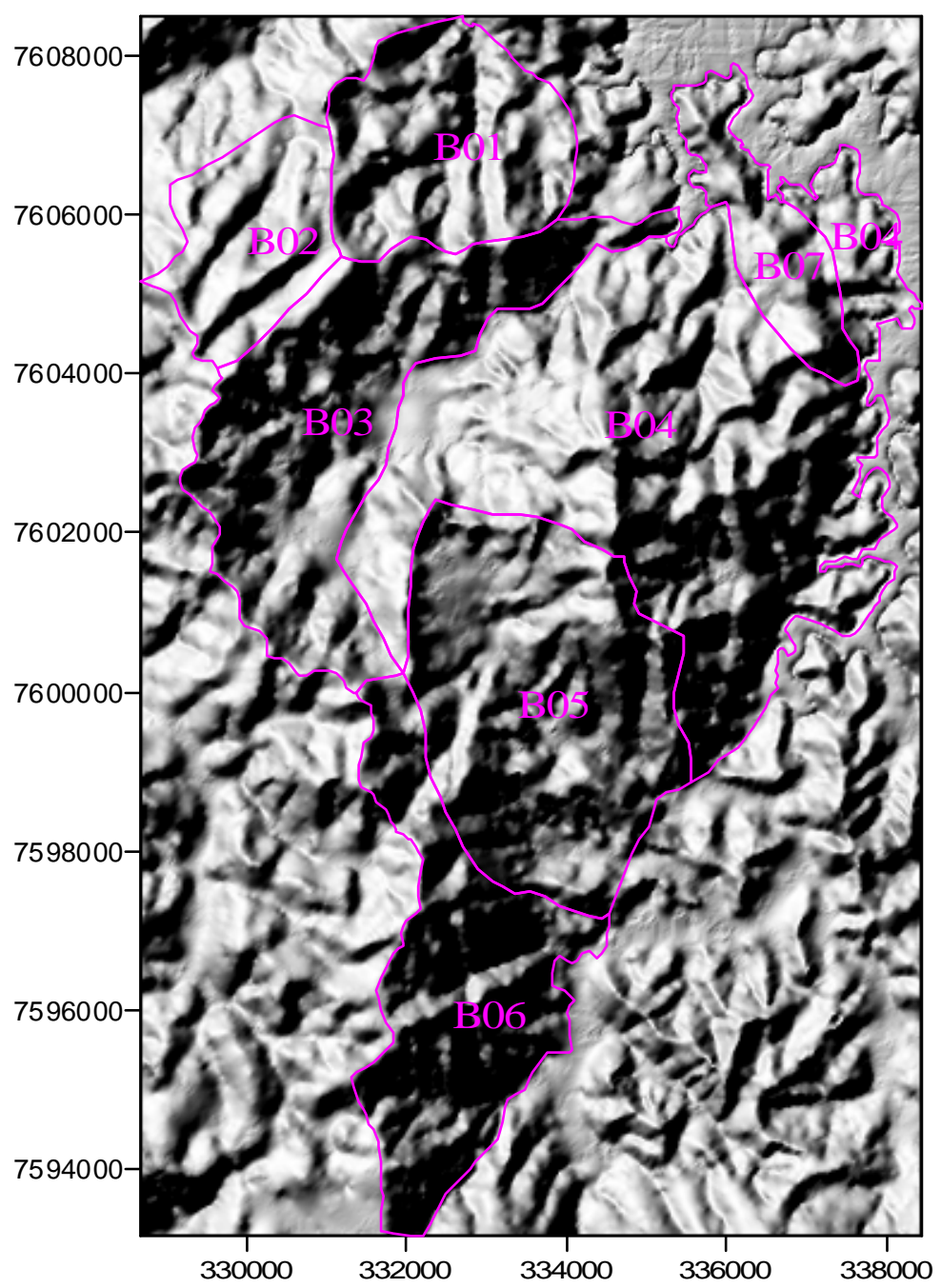

FIGURA 5.29 - Imagem sombreada do relevo mostrando a localização das unidades que compõem o Sistema de Terreno B.

Unidade B04 - É formada por morrotes com topos angulosos, encostas retilíneas, declividades médias, altas amplitudes de relevo, padrões de drenagem dendríticos com alta densidade de canais. Seu substrato rochoso apresenta granulitos quartzofeldspáticos $(58,41 \%$ da unidade) na porção noroeste e charnockitos $(41,49 \%$ da unidade) na sudeste. Seus materiais inconsolidados são formados por materiais do grupo textural $\mathrm{V}$ com espessuras variando entre 0,5 a $1,5 \mathrm{~m}$ na porção sudoeste (92,19\% da unidade) e materiais do grupo VI com espessuras de até 3,1 m no setor nordeste (7,81\% da unidade).A unidade B04 se estende por uma superfície de 25,81 $\mathrm{km}^{2}(5,35 \%$ do total). 


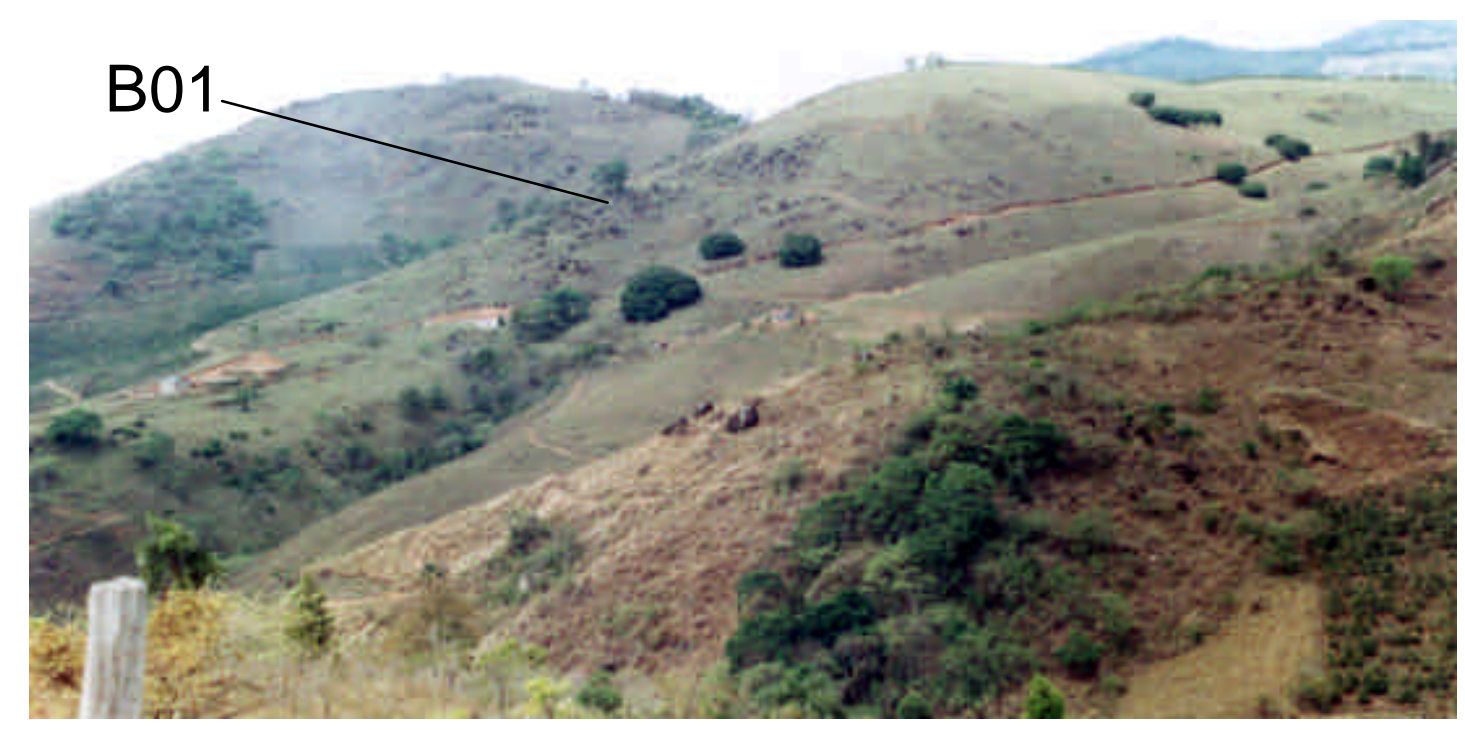

FIGURA 5.30 - Vista da Unidade B01.

Unidade B05 - Corresponde a vales abertos, encostas retilíneas, declividades altas, altas amplitudes de relevo, padrões de drenagem dendríticos com baixa densidade de canais. Ocupa $13,35 \mathrm{~km}^{2}$ (2,77 \% do total). Seu substrato rochoso é formado por charnockitos. Os materiais inconsolidados presentes são: materiais do grupo textural III com espessuras variando entre 1,5 a 3,0 m na porção sudeste e ocupando $10,82 \%$ da unidade; materiais do grupo textural $\mathrm{V}$ com espessuras inferiores a $0,5 \mathrm{~m}$ na porção sudoeste que se estendem por $13,85 \%$ da unidade e materiais do grupo textural V com espessuras variando entre 1,5 e 3,0 m na porção setor norte da unidade, representando $75,33 \%$ de sua extensão.

Unidade B06 - Ocupa $9,74 \mathrm{~km}^{2}(2,02 \%$ do total) e é formada por escarpas com topos e encostas retilíneas, altas declividades, amplitudes de relevo baixas, padrões de drenagem dendríticos com baixa densidade de canais. Seus materiais inconsolidados pertencentes ao grupo textural III ocupam um pequeno setor da porção ocidental (3,70\% da unidade) onde exibem espessuras que variam entre 1,5 e 3,0 . Contudo, na maior parte $(96,30 \%$ da unidade) os materiais inconsolidados presentes são do grupo textural $\mathrm{V}$, onde as espessuras desenvolvidas são inferiores a $0,5 \mathrm{~m}$. Seu substrato rochoso é composto por granulitos quartzo-feldspáticos 
Unidade B07 - Corresponde a morros com topos angulosos, encostas retilíneas, declividades altas, medias amplitudes de relevo, padrões de drenagem paralelo e baixa densidade de canais. Apresenta materiais inconsolidados do grupo VI com espessuras de até 3,2 m. Seu substrato rochoso é formado por charnockitos, sendo que a unidade ocupa $3,47 \mathrm{~km}^{2}(0,72 \%$ do total $)$

\section{SISTEMA C}

O Sistema de Terreno C (Figura 5.31) se desenvolve sobre as litologias migmatíticas do Complexo Varginha. Seus materiais inconsolidados têm origem residual e apresentam espessuras variando entre 1,5 a 3,0m. Além disso, pode-se afirmar que somente materiais das classes texturais III e V estão presentes. As únicas formas de relevo desenvolvidas são escarpas e colinas. O Sistema C ocupa $15,08 \mathrm{~km}^{2}$ $(3,13 \%$ do total).

Unidade C01 - Corresponde a escarpas com topos e encostas retilíneas, altas declividades, pequenas amplitudes de relevo, padrões de drenagem dendríticos com baixa densidade de canais. Migmatitos oftalmíticos compõem o substrato rochoso dessa unidade. O restante das unidades de terreno ( $\mathrm{C} 02, \mathrm{C} 03$ e $\mathrm{C} 04)$ é composto por migmatitos graníticos e estromatíticos. A unidade C01 ocupa 5,22 $\mathrm{km}^{2}(1,08 \%$ do total) onde se desenvolvem materiais inconsolidados do grupo textural III.

Unidade C02 - Estende-se por 1,87 $\mathrm{km}^{2}$ ( $0,39 \%$ do total) e é constituída por colinas com topos arredondados, altas declividades, encostas retilíneas, pequenas amplitudes de relevo, padrões de drenagem paralelos e baixa densidade de canais. Materiais inconsolidados do grupo textural III estão presentes nessa unidade.

Unidade C03 - Caracteriza-se por apresentar colinas de topos arredondados, encostas retilíneas, altas declividades, pequenas amplitudes de relevo, padrões de drenagem paralelos com baixa densidade de canais. Esta unidade ocupa 2,11 $\mathrm{km}^{2}$ $(0,44 \%$ do total $)$ onde se desenvolvem materiais inconsolidados do grupo textural $\mathrm{V}$. 


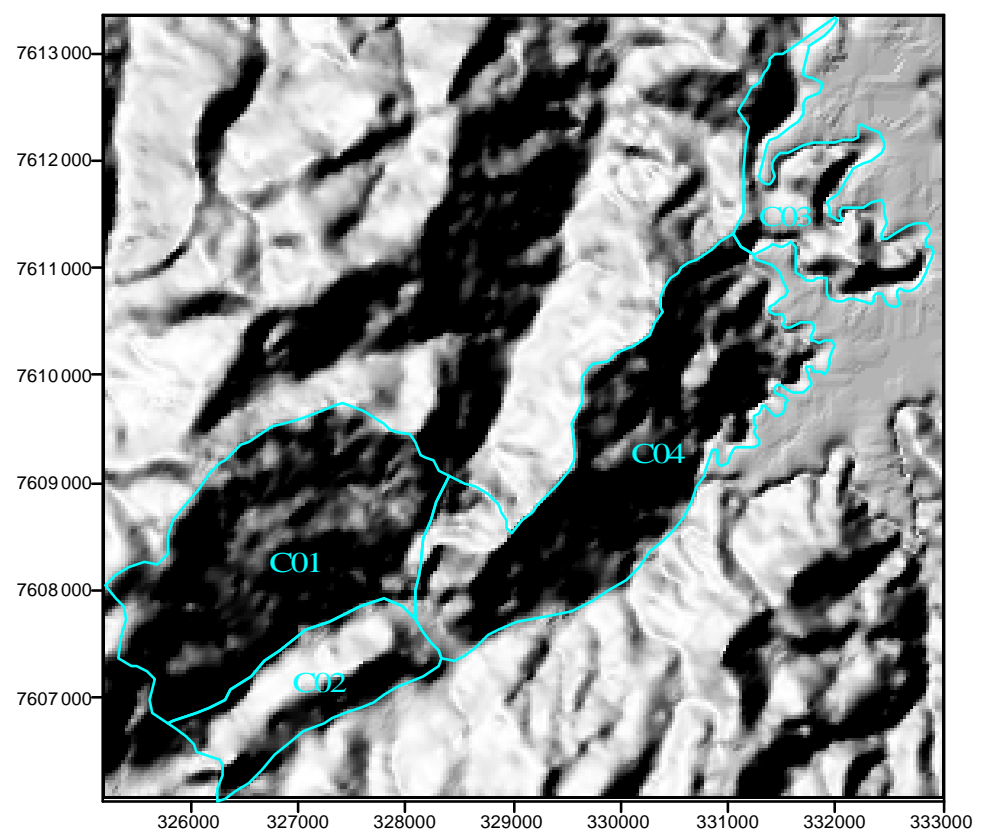

FIGURA 5.31 - Imagem sombreada do relevo mostrando a localização das unidades que compõem o Sistema de Terreno C.

Unidade C04 - Estende-se por 5,89 $\mathrm{km}^{2}$ (1,22\% do total) e é formada por escarpas com topos retilíneos, encostas retilíneas, altas declividades, pequenas amplitudes de relevo, padrões de drenagem paralelos com média densidade de canais. Seus materiais inconsolidados pertencentes ao grupo textural III localizam-se na sua porção sudoeste (23,63\% da unidade) enquanto que o restante de C04 é formada por materiais do grupo textural V (76,36\% da unidade). 


\section{SISTEMA D}

Associação de formas com ampla diversidade (colinas, vales, morros e escarpas) e que constituem a porção mais elevada da área em estudo (Figura 5.32). O Sistema D Estende-se por $128,06 \mathrm{~km}^{2}$ (26,55 \% do total). Apresenta substrato rochoso formado por migmatitos graníticos e estromatíticos do Complexo Varginha (Unidade D02), além de fonólitos (Unidades D01, D03, D04, D06, D07, D08 e D09) e nefelina sienitos (Unidades D05 e D10) do Maciço Alcalino de Poços de Caldas. Seus materiais inconsolidados exibem ampla diversidade com relação a gênese (residual e retrabalhada) classes texturais (I, III, IV, VI, VII e VIII) e espessuras (desde inferiores a $0,5 \mathrm{~m}$ a superiores a $3,0 \mathrm{~m}$ ).

Unidade D01 - Corresponde a escarpas com topos retilíneos, encostas côncavas, declividades médias, amplitudes de relevo baixas, padrões de drenagem dendríticos e densidade de canais média (Figura 5.33). Seus materiais inconsolidados pertencem a classe textural VII e desenvolvem espessuras variando entre 1,5 e 3,0 m, ocupando uma área de $4,31 \mathrm{~km}^{2}(0,89 \%$ do total $)$.

Unidade D02 - Estende-se por 29,20 $\mathrm{km}^{2}$ (6,06 \% do total) e caracteriza-se por apresentar escarpas com topos retilíneos, encostas convexas, altas declividades, altas amplitudes de relevo padrões de drenagem paralelos e média densidade de canais (Figura 5.34). Seus materiais inconsolidados são da classe textural I, de origem coluvionar e apresentam espessuras desde inferiores a $0,5 \mathrm{~m}$ a até $8,0 \mathrm{~m}$.

Unidade D03 - É formada por escarpas com topos retilíneos, encostas côncavas, altas declividades, amplitudes de relevo altas, padrão de drenagem paralelo e densidade de canais baixa. A unidade D03 ocupa 4,18 $\mathrm{km}^{2}$ (0,87\% do total), sendo seus materiais inconsolidados da classe textural VIII e com espessuras de até 9,0 m. 


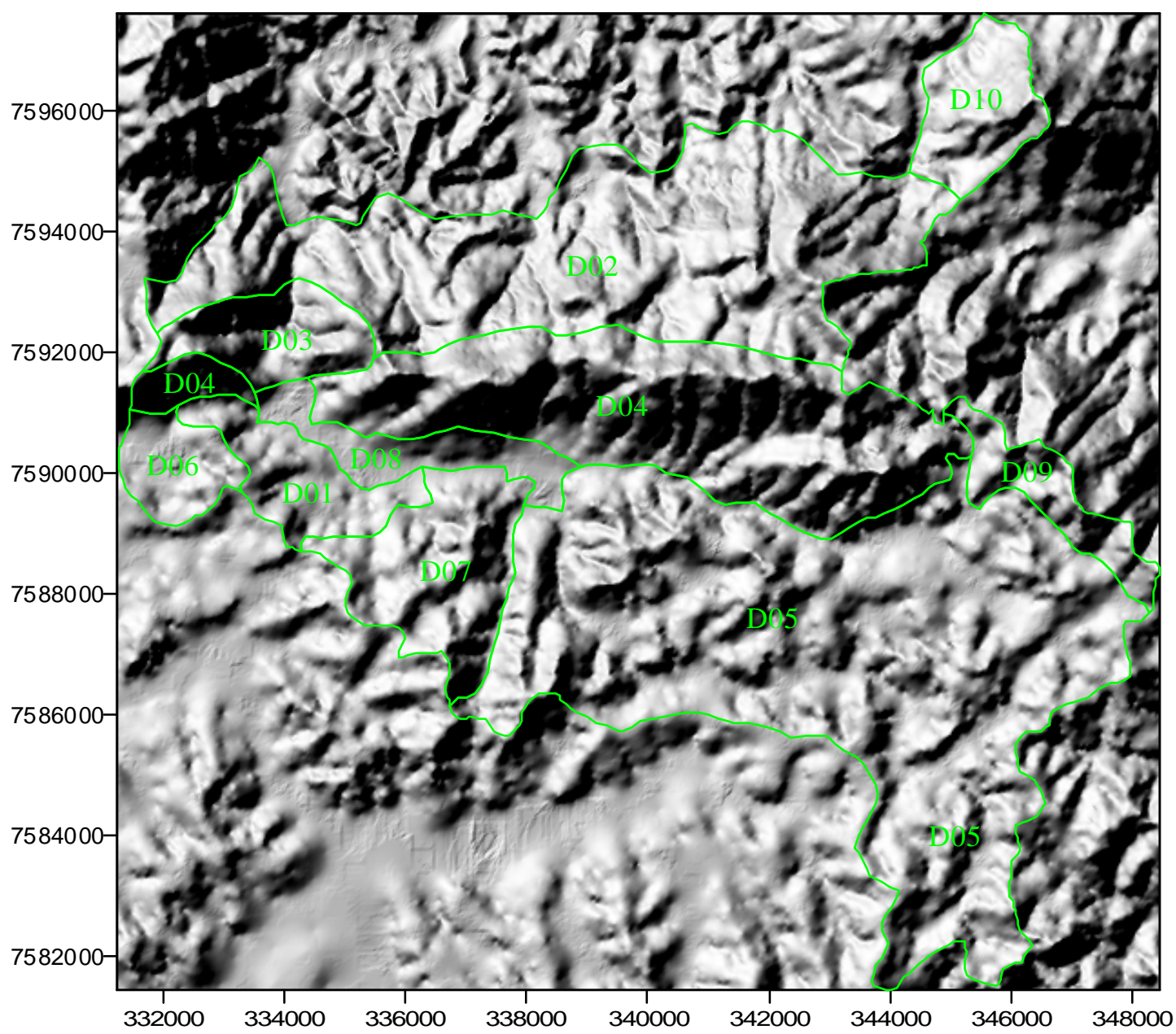

FIGURA 5.32 - Imagem sombreada do relevo mostrando a localização das unidades que compõem o Sistema de Terreno D.

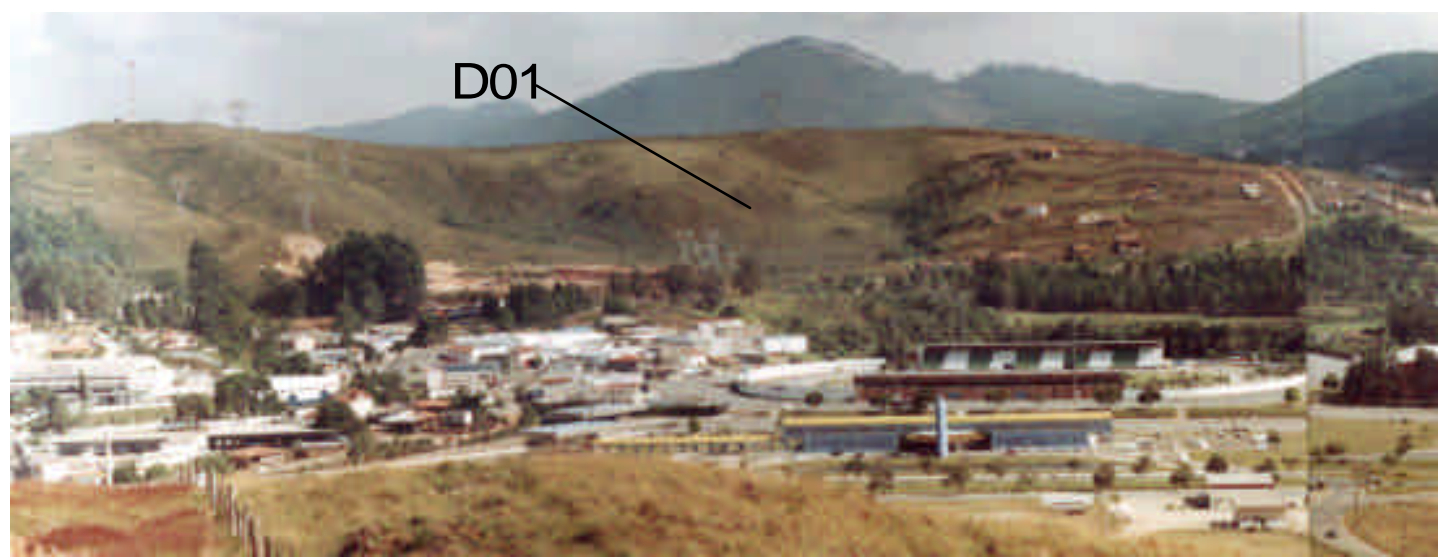

FIGURA 5.33 - Vista da Unidade D01. 


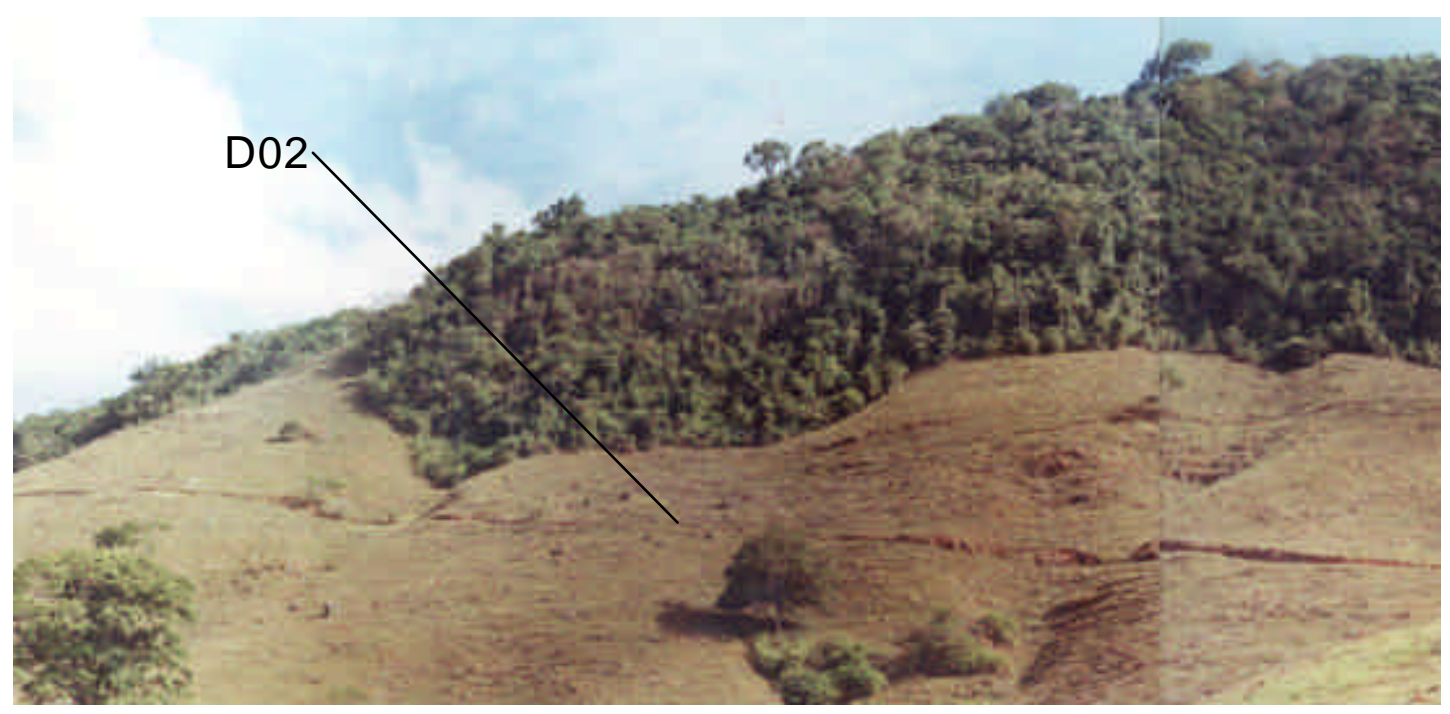

FIGURA 5.34 - Vista da Unidade D02.

Unidade D04 - Ocupa uma superfície de $21,81 \mathrm{~km}^{2}$ (4,52\% do total) e corresponde a escarpas de topo retilíneo, encostas retilíneas, declividades altas, amplitudes de relevo altas, padrões de drenagem paralelos com alta densidade de canais (Figura 5.35). Seus materiais inconsolidados são os mesmos presentes na unidade D03.

Unidade D05 - É formada por colinas com topos angulosos, encostas convexas, declividades médias, amplitudes de relevo médias, padrões de drenagem paralelos com média densidade de canais. Esta unidade estende-se por 47,21 km² $(9,79 \%$ do total), apresentando materiais inconsolidados residuais (cerca de 95,09\% da unidade) pertencentes a classe textural III com espessuras que variam entre 0,5 e 1,5 m. Além desses materiais próximo da porção central podem ser encontrados materiais retrabalhados da classe textural VI (4,91\% da unidade) cuja espessuras são inferiores a $0,5 \mathrm{~m}$.

Unidade D06 - A unidade D06 ocupa 2,79 $\mathrm{km}^{2}$ (0,58 \% do total). Caracteriza-se por apresentar vales abertos, encostas côncavas, baixas declividades e amplitudes de relevo. Seus materiais inconsolidados pertencem a classe textural IV e desenvolvem espessuras de até $3,3 \mathrm{~m}$. 


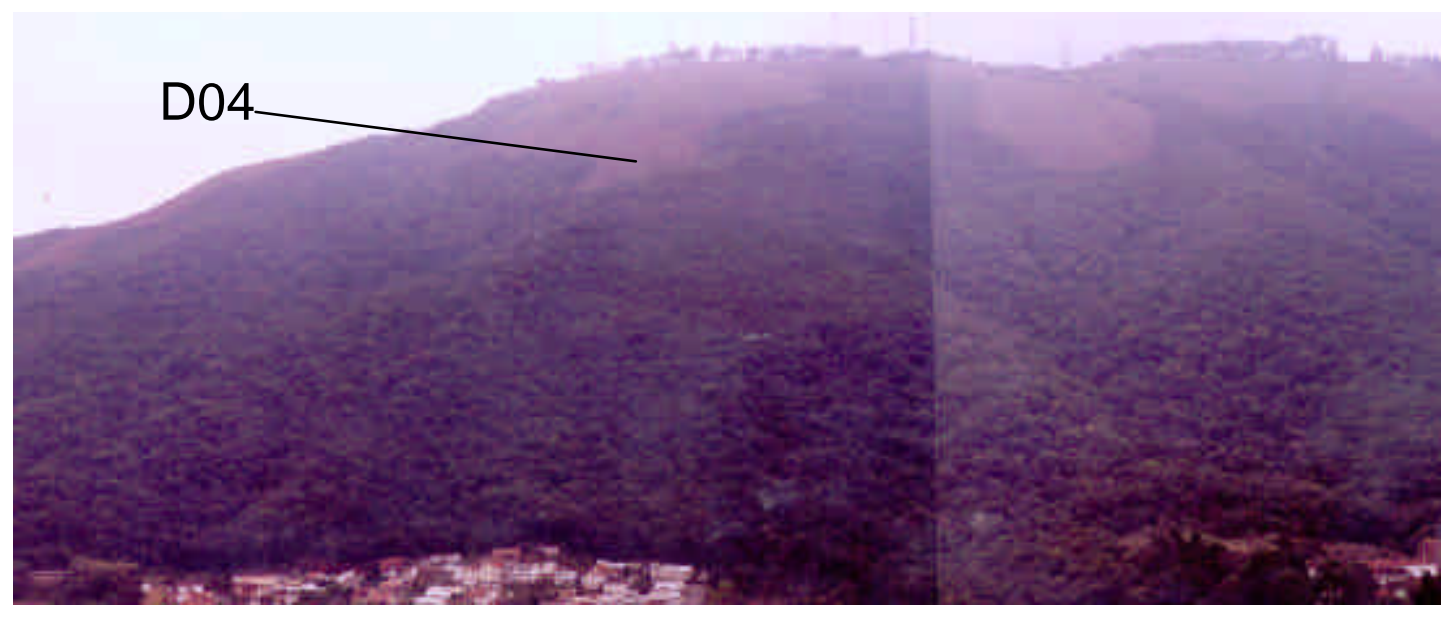

FIGURA 5.35 - Vista da Unidade D04.

Unidade D07 - Corresponde a morros com topos angulosos, encostas retilíneas, declividades altas, médias amplitudes de relevo, padrão de drenagem dendrítico e baixa densidade de canais. Com uma extensão de 7,43 $\mathrm{km}^{2}$ (1,54\% do total) apresenta materiais inconsolidados do grupo textural VII com espessuras variando entre 0,5 e $1,5 \mathrm{~m}$.

Unidade D08 - É formada por vales abertos, encostas convexas, baixas declividades e amplitudes de relevo. Seus materiais inconsolidados são os mesmos presentes na unidade D07 e ocupa uma área de $3,57 \mathrm{~km}^{2}(0,74 \%$ do total).

Unidade D09 - Corresponde a escarpas com topos retilíneos, encostas convexas, declividades médias, pequenas amplitudes de relevo, padrão de drenagem dendrítico e com baixa densidade de canais. D09 ocupa $3,23 \mathrm{~km}^{2}(0,67 \%$ do total). Seus materiais inconsolidados correspondem ao grupo textural III com espessuras variando entre 0 e $0,5 \mathrm{~m}$.

Unidade D10 - É formada por morrotes com topos angulosos, encostas retilíneas, altas declividades, amplitudes de relevo altas (> $300 \mathrm{~m}$ ), padrões de drenagem paralelos com baixa densidade de canais (Figura 5.36). Seus materiais inconsolidados pertencem ao grupo textural I, tem origem coluvionar e apresentam espessuras que variam desde inferiores a $0,5 \mathrm{~m}$ a até $3,5 \mathrm{~m}$. A Unidade D10 se estende por uma superfície de $4,34 \mathrm{~km}^{2}$ (0,90\% do total). 


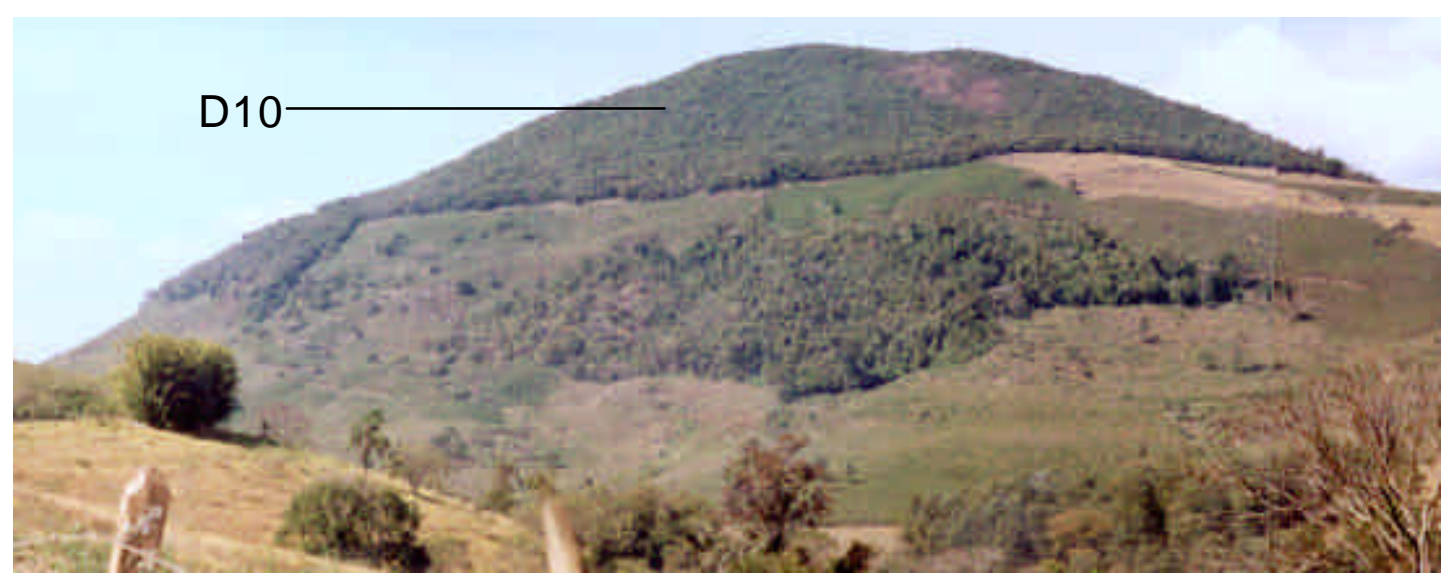

FIGURA 5.36 - Vista da Unidade D10.

Uma vez completada a fotointerpretação e a delimitação dos sistemas e unidades de terreno nas fotografias aéreas, ocorre a restituição desses setores classificados utilizando o aerosketchmaster para a base topográfica disponível.

O processo final de construção do mapa de landforms abrange etapas de escaneamento do documento restituído assim como seu referenciamento, digitalização e edição final no AutoCad Map 2000 (Figura 5.37).

A descrição das unidades de terreno forneceu um grande número de dados sobre a área estudada. Portanto, para cada uma delas foram definidas: feição de relevo, forma do topo ou tipo de vale, tipo de encosta, declividade, padrão de drenagem e densidade de drenagem.

Deste modo, procuroutse a partir da interpretação das informações disponíveis utilizar algum tipo de análise que apontasse relação entre os níveis hierárquicos de terreno definidos por Lollo (1996) como mostra a Tabela 5.25.

Assim, a exemplo da utilização de estatística multivariada para a seleção das classes texturais no mapa de materiais inconsolidados, optou-se pelo emprego de análise de agrupamentos hierárquicos no tratamento das informações coletadas para o mapa de landforms.

Desse modo, foi escolhido a técnica de agrupamento por ligação completa que utiliza como medida de distância o percentual de discordância para classificar os níveis taxonômicos de terrenos, tal operação fora realizada pois tal técnica permite a análise estatística de dados cuja a natureza é nominal (alfanumérica). 


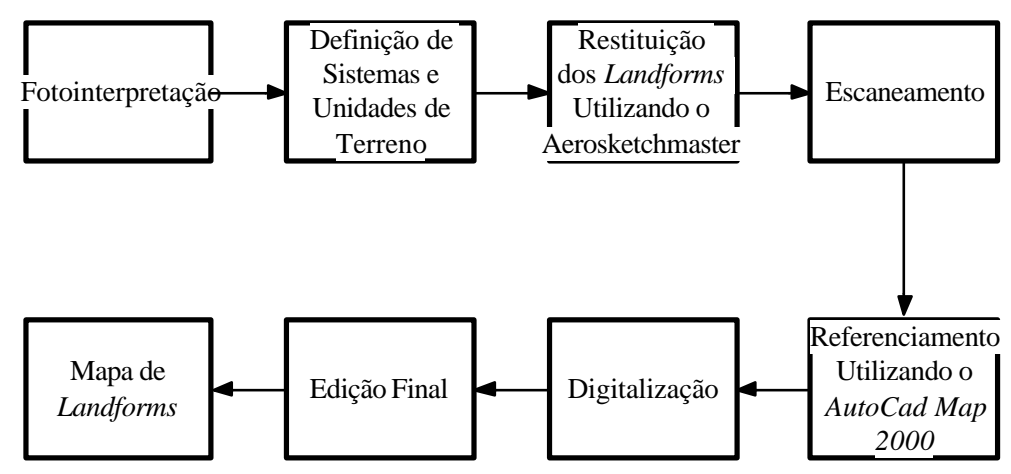

FIGURA 5.37 - Etapas seguidas para a construção do Mapa de Landforms.

As variáveis utilizadas foram: feição de relevo, forma do topo ou tipo de vale, tipo de encosta, declividade, padrão de drenagem e densidade de drenagem. As análises foram realizadas utilizando o software STATISTICA® 5.5.

Os primeiros resultados não se mostraram satisfatórios porque os agrupamentos obtidos não mostravam nenhuma similaridade com o que havia sido proposto por fotointerpretação. Contudo, esses resultados começaram a melhorar a partir do momento que foi levado em consideração o conceito de Lollo (1996) para Sistema de Terreno.

Segundo o autor o Sistema de Terreno representa a associação de feições de relevo com expressão espacial determinada e que representa condições similares de processos evolutivos e de materiais rochosos associados.

Examinando o conceito, observa-se que unidades do mesmo sistema tendem a apresentar materiais rochosos similares, portanto, substratos rochosos de mesma natureza. Do mesmo modo, unidades que compõem o mesmo sistema tendem a experimentar o mesmo processo evolutivo, dessa maneira, também devem experimentar o mesmo período de tempo desde suas formações até o estágio que se encontram hoje.

Baseado nessas qualidades, optoutse por acrescentar variáveis que representassem tais condições, desse modo foram incluídos o tipo, a mineralogia e a idade do substrato rochoso presentes em cada Unidade de Terreno. 
A inclusão da variável mineralogia é justificada pois na área em estudo ocorrem exemplos de substratos rochosos com diferentes denominações e que apresentam composição mineralógica muito parecidas, portanto tendem a gerar produtos de alteração muito similares.

A partir dessas considerações ficaram estabelecidas algumas condições para execução da análise de agrupamento. A primeira delas é que a classificação feita para o mapa de substrato rochoso seria utilizada sem nenhuma generalização ou subdivisão nas Unidades de Terreno, exceção feita aos migmatitos e entre os nefelina sienitos e os fonólitos.

A última condição diz respeito ao tempo de desenvolvimento dos processos evolutivos que experimentaram as unidades. Desse modo, consideroutse as litologias do Complexo Varginha como relativas ao período pré-cambriano e as do Complexo Alcalino de Poços de Caldas a Era Mesozóica.

Uma vez superadas essas etapas, foram realizadas diversas análises, inicialmente considerando todas as variáveis e depois retirando cada uma delas e mantendo o restante. Ao final desse procedimento, observou-se que o melhor resultado foi atingido quando na análise foi suprida a variável feição de relevo.

Acredita-se que a inserção da variável feição de relevo deve prejudicar a análise de agrupamento, pois esta freqüentemente traz consigo uma série de características de outras variáveis. Assim, quando se define que determinadas feições são compostas por escarpas já se sabe que seus topo não são arredondado, ou ainda, que morrotes jamais possuem pequenas amplitudes de relevo.

A análise pelo modo Q (Figura 5.38) demonstra um agrupamento muito similar ao realizado utilizando fotografias aéreas considerando que o Sistema de Terreno C corresponde a um sistema de transição, podendo ter unidades tanto pertencentes ao Sistema de Terreno A quanto B.

Assim, quando o percentual de discordância atinge $78 \%$ se observa que apenas cinco unidades (A08, A10, B01, B02 e D02) não pertencem aos mesmos sistemas definidos em fotografias aéreas, tal conjunto perfaz apenas uma diferença percentual em torno de 16,13\% num universo de trinta e uma unidades (Tabela 5.40). 


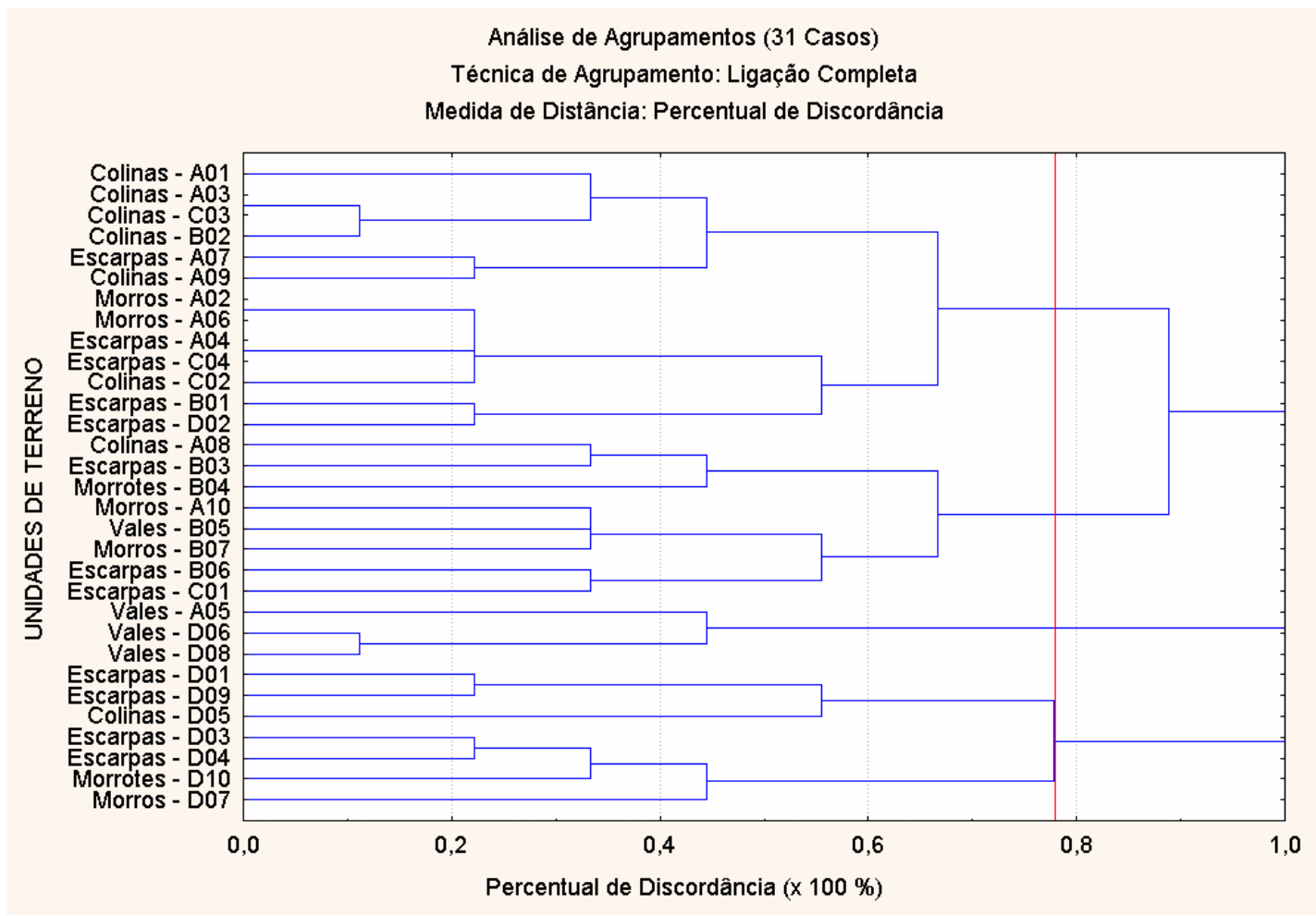

FIGURA 5.38 - Análise de agrupamentos entre as Unidades de Terrenos (modo Q) presentes no Mapa de Landforms.

TABELA 5.40 - Comparação entre os resultados obtidos na composição dos Sistemas de Terreno por meio da Técnica de Avaliação de Terreno de Lollo (1996) em relação aos definidos pela análise de agrupamentos, para isso, considerando as condições de contorno estabelecidas para área em estudo.

\begin{tabular}{|c|}
\hline $\begin{array}{c}\text { SISTEMAS DE TERRENOS DELIMITADOS POR FOTOGRAFIAS } \\
\text { ÁEREAS }\end{array}$ \\
\hline Sistema A: A01, A02, A03, A04, A05, A06, A07, A08, A09 e A10 \\
\hline Sistema B: B01, B02, B03, B04, B05, B06 e B07 \\
\hline Sistema C: C01, C02, C03 e C04 \\
\hline Sistema D: D01, D02, D03, D04, D05, D06, D07, D08, D09 e D10 \\
\hline
\end{tabular}

\section{SISTEMAS DE TERRENOS AGRUPADOS PELO DENDOGRAMA}

Sistema A: A01, B01, A02, B02, C02, D02, A03, C03, A04, C04, A06, A07 e A09

Sistema B: C01, B03, B04, B05, B06 e B07 A08 e A10

Sistema D: D01, D03, D04, D05, D07, D09 e D10

Sistema E (Vales): A05, D06 e D08 
O dendograma indica ainda a existência de um outro sistema formado exclusivamente por vales (Tabela 5.40), o que também pode ser considerado como aceitável, uma vez que essas feições de relevo possuem uma descrição bem particular quando compõem unidades de terreno (ausência de topo, forma de seu vale, etc).

\subsubsection{Mapa de Uso e Ocupação}

O mapa de uso e ocupação (ANEXO VI) é o documento cartográfico que representa a disposição espacial das atividades e distribuição dos meios biológico e antrópico sobre o meio físico para um intervalo de tempo definido.

É através do mapa de uso e ocupação que se pode avaliar, medir, planejar e até mesmo fiscalizar as atividades humanas que tragam sérios danos ao meio ambiente.

A confecção de tal documento cartográfico nessa pesquisa envolveu o uso de imagens de satélite, contudo também poderiam ser utilizadas fotografias aéreas, desde que recentes.

O passo inicial de construção do mapa de uso e ocupação foi a aquisição de imagens do LANDSAT 5 (Figura 5.39) datadas de setembro de 1999 e a definição do software ENVI ® 3.2 como responsável pelo processamento digital das imagens. A partir de então, foram escolhidas as Bandas 4, 5 e 3 (Figura 5.40) para o processamento digital, isso porque, para esse tipo de satélite, tais bandas são as mais indicadas quando se deseja observar os padrões de uso e ocupação.

O passo seguinte foi a delimitação e edição, dentro da cena do LANDSAT, do polígono regular que contém a área em estudo, desse modo, o georeferenciamento e a classificação da imagem se tornariam mais eficazes, uma vez que o processamento não seria realizado sobre toda a cena onde não se dispunha de informação.

A correção geométrica, ou georeferenciamento, de acordo com o Guia do ENVI 3.5 em Português (2002), é feita pelo ajuste de uma imagem ou de um arquivo vetorial a um espaço definido por um sistema de coordenadas de referência, no caso utilizado desta o Sistema UTM. 


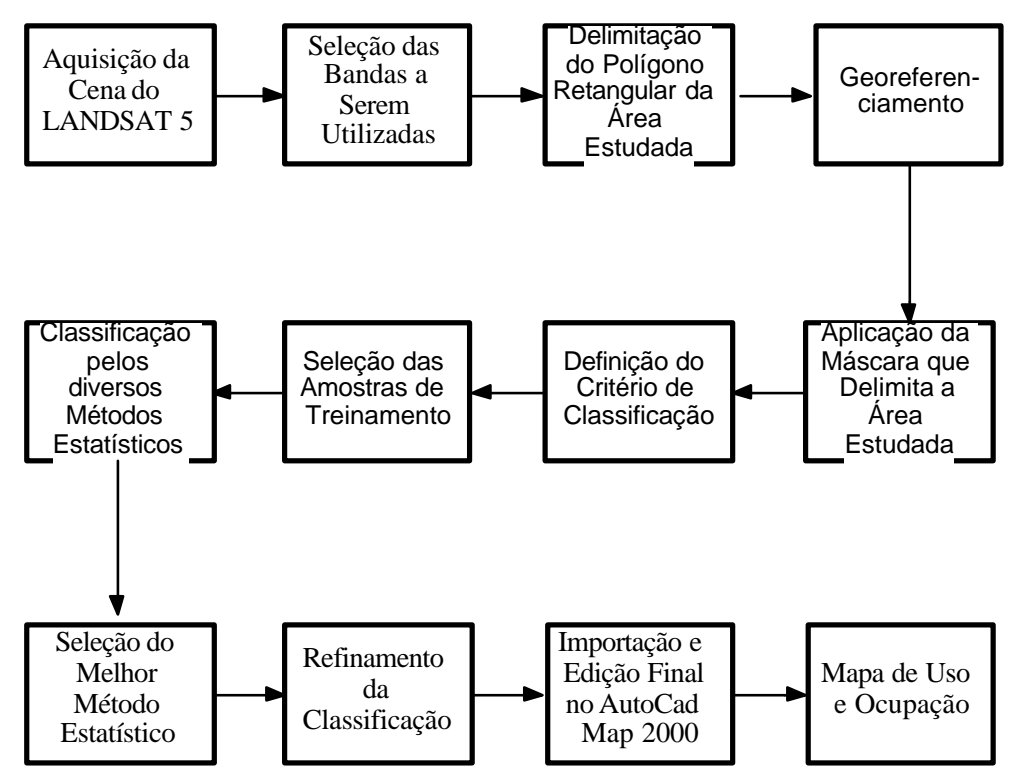

FIGURA 5.39 - Etapas seguidas para a construção do Mapa de Uso e Ocupação.

Assim, utilizando um arquivo de pontos de controle da imagem, que o próprio software gerou, baseados em pontos obtidos a partir dos folhas topográficas, (Caconde, Botelhos, Caldas e Poços de Caldas) foi calculado o valor RMS (Erro Médio Quadrático).

Segundo o Guia do ENVI 3.5 em Português (2002) “O Erro médio quadrático é uma medida do desvio dos valores calculados em relação aos valores originais. $O$ erro RMS é estimado tomando-se uma amostra dos valores calculados e comparando-a com seus valores reais. As diferenças entre elas são então elevadas ao quadrado e somadas. A soma é então dividida pelo número de medidas, para que se atinja um valor cuja raiz quadrada fornece uma medida característica de erro na mesma unidade das medidas originais. O erro RMS é diretamente comparável ao conceito de desvio padrão”.

Para área estudada foram utilizados 13 pontos de coordenadas conhecidas identificados nas cartas topográficas. O RMS calculado para imagem apontou um valor de 1,6985 . 


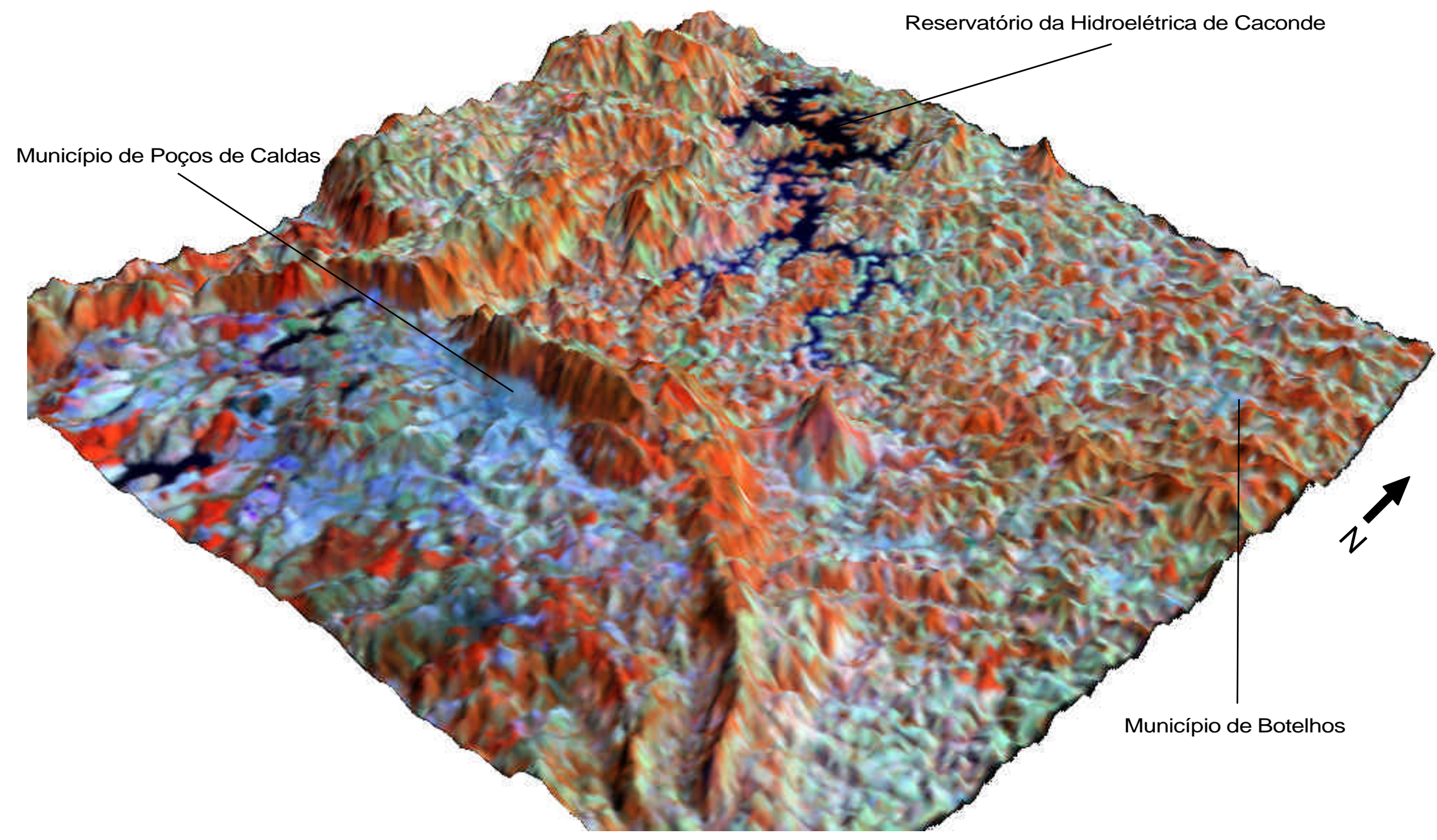

FIGURA 5.40 - Bandas 4, 5 e 3 do LANDSAT 5 sobrepostas ao MDT gerado para área estudada utilizando o ArcView® 3.1. 
Segundo o Guia do ENVI 3.5 em Português (2002) as etapas finais de correção geométrica incluem duas fases de processamento. A primeira delas é transformação de coordenadas em pixels, a outra é conhecida como reamostragem, ou seja, é a etapa responsável pela determinação do valor do pixel na imagem a ser registrada. Para primeira etapa foi utilizada a transformação polinomial de $2^{\mathrm{a}}$ ordem enquanto que na segunda a convolução cúbica.

A próxima fase executada para o processamento da imagem foi a utilização de um filtro chamado de máscara, filtro esse cuja finalidade é excluir do processamento digital da imagem os setores externos ao limite da área estudada. Tal procedimento visa a melhoria do processamento uma vez que aumenta a eficiência da classificação.

O ENVI ® 3.2 permite ao usuário a definição de dois critérios de classificação. O primeiro chamado de classificação não supervisionada é geralmente utilizado quando não se possui informação a cerca da área estudada, ou ainda quando se deseja obter uma classificação preliminar para auxiliar na busca de informações voltada para uma classificação posterior, do tipo supervisionada.

A classificação supervisionada, o outro critério de classificação oferecido pelo ENVI ® 3.2, foi utilizada na pesquisa uma vez que as etapas de campo realizadas trouxeram informações que puderam ser utilizadas na composição das amostras de treinamento (Figura 5.41).

Desse modo, puderam ser definidas cinco tipos de amostras de treinamento, são elas:

a) Água represada: representada pelo reservatório da Hidroelétrica de Caconde e pelos diversos pequenos corpos de água na forma de barragens e lagos

b) Floresta nativa: representada pela Floresta Mesófila

c) Áreas destinadas a pecuária bovina extensiva: representadas pelos campos de pastagem.

d) Áreas sem cobertura vegetal: representadas pelos setores que apresentaram solos expostos (áreas desmatadas).

e) Monocultura cafeteira: representada pelas áreas onde o café é cultivado independente de seus estágios de desenvolvimento. 

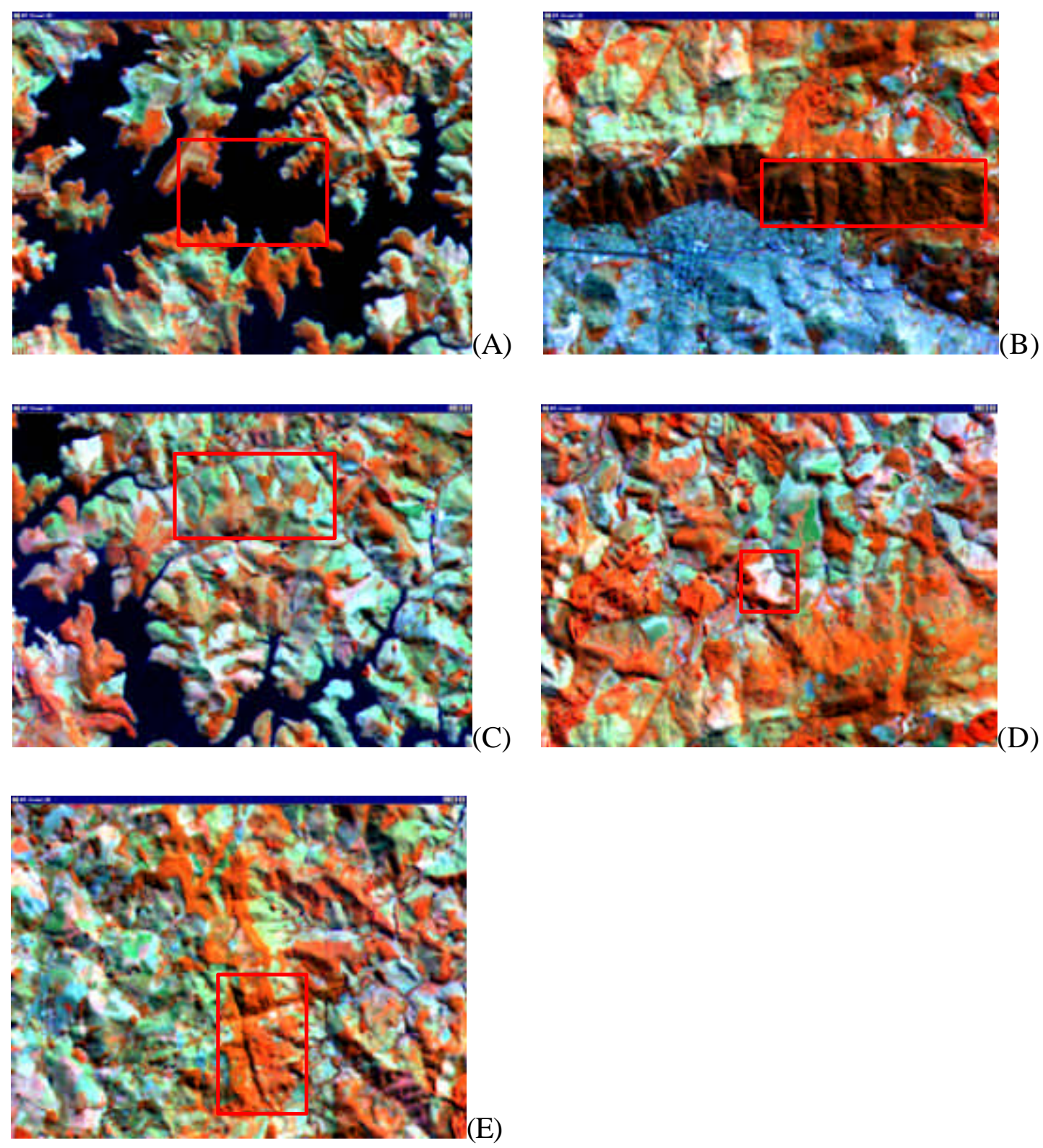

FIGURA 5.41 - Aparência das amostras de treinamento das classes de uso e ocupação da área estudada a partir das composições das bandas 4, 5 e 3 do LANDSAT 5. As classes utilizadas são: água represada (A), floresta nativa (B), áreas destinadas a pecuária bovina extensiva (C), áreas sem cobertura vegetal (D), monocultura cafeteira (E). 
A classe que representa áreas urbanizadas não teve incluídas amostras de treinamento. De acordo com Novo (1989) devido a diversidade de materiais que compõe os centros urbanos essas áreas não apresentam comportamento espectral homogêneo, portanto dificultam o processamento em função de sua variância interna muito grande.

A etapa seguinte envolveu a classificação por seis tipos de algoritmos que o ENVI ® 3.2 apresenta, são eles: Método do paralelepípedo, Método da distância mínima, Método da máxima verossimilhança, Mapeador de ângulo espectral, Classificação por distância de Mahalanobis e Classificação por "Binary Encoding".

O ENVI ${ }^{\circledR} 3.2$ possibilita a avaliação dos resultados das classificação através de seu módulo de matriz de confusão ou de erros. Tal módulo fornece para cada algorítimo a sua exatidão global e o seu coeficiente kappa.

De acordo com o Guia do ENVI 3.5 em Português (2002) a exatidão global pode ser compreendida como a relação percentual entre o número de pixels bem classificados nos setores ocupados pelas amostras de treinamento pelo número total de pixels que as amostras de treinamento ocupam, que no caso dessa pesquisa correspondem a uma superfície de 7,47 \% da área estudada.

Ainda segundo o Guia do ENVI 3.5 em Português (2002), coeficiente kappa incorpora a informação dos pixels mal classificados, e não apenas dos bem classificados como a exatidão global. O kappa é sensível não só a perda de acurácia global como as variações dos erros de omissão e de inclusão de pixels nas diferentes classes de usos definidas.

Os resultados na Tabela 5.41 apontam o método da máxima verossimilhança com o melhor valor de exatidão global e coeficiente kappa, fazendo assim do resultado da classificação da imagem por esse algoritmo, como o utilizado nessa pesquisa.

O ENVI ® 3.2 permitiu posteriormente a classificação a aplicação de filtros que tem o objetivo de reduzir a quantidade de pixels mal classificados (ruídos) não imagem. 


\begin{tabular}{|c|c|c|}
\hline Algoritmo & Exatidão Global & Coeficiente kappa \\
\hline Método do paralelepípedo & $42,10 \%$ & 0,25 \\
\hline Método da distância mínima & $90,39 \%$ & 0,86 \\
\hline Método da máxima verossimilhança & $94,87 \%$ & 0,93 \\
\hline Mapeador de ângulo espectral & $62,32 \%$ & 0,50 \\
\hline Classificação por distância de Mahalanobis & $88,92 \%$ & 0,84 \\
\hline Classificação por "Binary Encoding" & $79,94 \%$ & 0,70 \\
\hline
\end{tabular}

TABELA 5.41 - Valores de exatidão global e coeficiente kappa obtidos para imagem da área estudada a partir dos algoritmos de classificação supervisionada fornecidos pelo ENVI ${ }^{\circledR} 3.2$.

O primeiro filtro utilizado foi o de convolução mediana, de acordo com Collares (2000) este filtro permite a remoção de ruídos, provocando um efeito de suavização. O processo é efetuado com uma máscara por cima da imagem, geralmente utilizando-se uma matriz $3 \times 3$, onde o pixel central é substituído pelo valor médio de seus vizinhos.

Os outros filtros utilizados foram o Clump e Sieve. Segundo Collares (2000) estes servem, respectivamente, para aglutinar ou separar pixels isolados envoltos ou próximos de um grupo de pixels de uma determinada classe. $\mathrm{O}$ autor destaca como aspecto negativo que o processamento é efetuado em toda imagem e não apenas em pontos isolados, fato este que pode provocar distorções em locais indesejados.

O último estágio na classificação da imagem é a inserção das áreas urbanizadas através do aplicativo classedit. Assim, por meio da digitalização dos limites dos centros urbanos tendo como imagem de fundo as composições das bandas 4,5 e 3, pode-se delimitar com precisão os limites dessa classe.

A matriz de erro dessa nova imagem apontou uma melhora nos valores de exatidão global e coeficiente kappa, passando a primeira de 94,87\% para 96, $88 \%$ e a segunda de 0,93 para 0,95 .

A ultima etapa de construção do mapa de uso e ocupação envolveu a importação do arquivo do ENVI ® 3.2 no formato BMP por parte do AutoCad Map 2000 e consequentemente a realização da edição no mesmo programa. O resultado da distribuição das classes desse mapa pode ser apreciado na Tabela 5.42. 
TABELA 5.42 - Resultados da distribuição das classes para o Mapa de Uso e Ocupação.

\begin{tabular}{|c|c|c|}
\hline Classe de Uso e Ocupação & $\begin{array}{l}\text { Total de Área Ocupada } \\
\text { em km } \mathbf{~ k m}^{\mathbf{2}}\end{array}$ & $\begin{array}{l}\text { Percentual da Área } \\
\text { Ocupada }\end{array}$ \\
\hline Água represada & 26,73 & 5,25 \\
\hline Floresta nativa & 93,19 & 18,31 \\
\hline $\begin{array}{l}\text { Áreas destinadas a pecuária } \\
\text { bovina extensiva }\end{array}$ & 234,58 & 46,08 \\
\hline $\begin{array}{c}\text { Áreas sem cobertura } \\
\text { vegetal }\end{array}$ & 14,62 & 2,87 \\
\hline Monocultura cafeteira & 117,12 & 23,01 \\
\hline Áreas urbanizadas & 22,15 & 4,35 \\
\hline Setores não classificados & 0,66 & 0,13 \\
\hline TOTAL & 509,05 & 100,00 \\
\hline
\end{tabular}

\subsubsection{Carta de Potencial Agrícola}

A carta de potencial agrícola (ANEXO VII), especificamente para essa pesquisa, tem a finalidade de classificar e delimitar de modo relativo a área estudada quanto a sua aptidão agrícola geral.

Desse modo, o objetivo desse documento cartográfico é diferenciar setores que apresentem por exemplo solos espessos, bem graduados, profundos, com alta capacidade de troca catiônica, situados em áreas de baixa declividades e que não tenham nenhuma restrição legal quanto ao uso como setores favoráveis a atividade agrícola de forma geral.

Por outro lado, deseja-se delimitar do mesmo modo como áreas restritivas, por exemplo, aquelas que apresentem solos muito arenosos, rasos, com baixo CTC situadas em terrenos com altas declividades.

Além disso, buscou-se ainda mapear áreas que apresentem adequabilidades intermediárias entre restritivas e favoráveis (adequabilidades severas e moderadas) além de setores que possuam restrições legais quanto ao uso agrícola. 
A exemplo da confecção da carta de potencial agrícola produzida por Grecchi (1998), esse documento cartográfico geotécnico foi elaborado baseando-se nos atributos propostos por Zuquette (1993), conforme mostra a Tabela 5.42, com o objetivo de obter uma avaliação geral das potencialidades e limitações da região quanto aos aspectos agrícolas. Desse modo, não se pretendeu entretanto, avançar neste assunto, tanto pela falta de aptidão técnica, por se tratar de um ramo específico da agronomia, quanto por se tornar inviável dentro dos objetivos desse trabalho.

O passo inicial para construção da carta foi a seleção dos atributos propostos por Zuquette (1993) (presentes na Tabela 5.43) que poderiam ser obtidos tomando como base os dados levantados nessa pesquisa.

Desse modo, percebeu-se que as classes de adequabilidades de aptidão agrícola relativas a espessuras, a textura e a capacidade de troca catiônica dos materiais inconsolidados, poderiam ser obtidas facilmente por meio de uma reclassificação do mapa de materiais inconsolidados em três planos de informações distintos seguindo os intervalos propostos por Zuquette (1993), conforme mostra a figura 5.42 e a Tabela 5.44.

Com relação as classes de adequabilidades do atributo declividade, essas deveriam ser definidas a partir da reclassificação das declividades geradas pelo MDT, uma vez que as classes utilizadas na carta de declividades não coincidiram com as proposta por Zuquette (1993).

A etapa seguinte envolveu a definição de um peso específico para cada classe de adequabilidades (favorável, moderada, severa e restrita) em cada um dos planos de informação (espessuras, texturas, CTC e declividade) gerados, desse modo tais planos puderam ser adicionados um a um dentro do SIG Idrisi ${ }^{\circledR} 32$ para posterior reclassificação em intervalos julgados adequados.

Ficou ainda estabelecido que os planos de informações deveriam possuir o mesmo peso quando comparados entre si, portanto, dessa forma, todas as classes de adequabilidades dos planos de informações, quando analisadas individualmente nos diferentes mapas, deveriam ter a mesma unidade. Os valores atribuídos para cada classe de adequabilidade nessa pesquisa foram: favorável igual a 1 , moderada 2 , severa 3 e restritiva 4 (Figura 5.43). 
TABELA 5.43 - Combinação de atributos e níveis que definem as classes da carta de potencial agrícola (Fonte: Zuquette, 1993)

\begin{tabular}{|c|c|c|c|c|c|}
\hline & & & Cla & & \\
\hline Componentes & Atributos & Favorável & Moderada & Severa & Restritiva \\
\hline $\begin{array}{l}\text { Substrato } \\
\text { Rochoso }\end{array}$ & Profundidade $(\mathrm{m})$ & $>1,5$ & $>0,7$ & $<0,5$ & $<0,2$ \\
\hline & Textura & $\begin{array}{c}\text { Média Argilo- } \\
\text { Arenosa e } \\
\text { Argilosa }\end{array}$ & $\begin{array}{c}\text { Areia } \\
(<30 \%)\end{array}$ & $\begin{array}{l}\text { Arenosa } \\
(>90 \%)\end{array}$ & $\begin{array}{c}\text { Arenosa/ } \\
\text { Argilas } \\
\text { expansivas }\end{array}$ \\
\hline & Estruturas & $\begin{array}{l}\text { Moderado ou } \\
\text { sem }\end{array}$ & & & $\begin{array}{l}\text { Maciça, } \\
\text { estrutura } \\
\text { grosseira }\end{array}$ \\
\hline & Consistência & Friável & & Dura & Muito dura \\
\hline & Níveis de Umidade & Boa retenção & & & Baixa retenção \\
\hline & $\begin{array}{l}\text { C.T.C. (cap. troca } \\
\text { catiônica) } \\
\text { (meq/100g TFSA) }\end{array}$ & $\begin{array}{c}>20 \mathrm{meq} / 100 \\
\text { (superficial) } \\
>10 \mathrm{meq} / \\
\text { (subsuperficial) }\end{array}$ & $\begin{array}{c}10 \mathrm{meq} / 100 \mathrm{~g} \\
\text { (superfic.) } 5 \\
\text { meq/100 g } \\
\text { (subsuperficial) }\end{array}$ & $\begin{array}{c}>2 \text { meq/100 } \\
\text { (superf. e } \\
\text { subsuperficial) }\end{array}$ & $<2 \mathrm{meq} / 100 \mathrm{~g}$ \\
\hline & $\Delta \mathrm{pH}$ & Negativo & & & Positivo \\
\hline & $\mathrm{PH}$ & $5,5-7,5$ & & & $<4>8$ \\
\hline II & Nutrientes & Altos níveis & & & Baixos níveis \\
\hline & Pedregosidade & Sem ocorrência & \begin{tabular}{|c|} 
Pequena \\
ocorrência $(0,1$ \\
$-1 \%)$
\end{tabular} & Média (> $2 \%)$ & $\begin{array}{c}\text { Alta ocorrência } \\
\text { (> } 3 \%)\end{array}$ \\
\hline & $\begin{array}{|ll|}\text { Salinidade } & \text { Ece } \\
\text { MS/CM } & \\
\end{array}$ & $>2$ & $2-8$ & $8-15$ & $>15$ \\
\hline & $\begin{array}{c}\text { Sódio } \\
\text { (meq/100 g) }\end{array}$ & $>0,2$ & $0,2-1$ & $>1$ & $>2$ \\
\hline & $\begin{array}{l}\text { Sódio trocável } \\
\text { Nat/C.T.C. (\%) }\end{array}$ & $>2$ & $2-10$ & $>10$ & $>15$ \\
\hline & $\begin{array}{l}\text { Capacidade } \\
\text { Campo - Ponto de } \\
\text { murchamento }(\Delta \mathrm{m})\end{array}$ & Alto & Médio & Baixo & Baixo \\
\hline & $\begin{array}{|ll|}\text { Porcentagem } & \text { Mat. } \\
\text { Orgânica } & \\
\end{array}$ & $>4 \%$ & $2 \%$ & $1 \%$ & $<0,1$ \\
\hline
\end{tabular}

\footnotetext{
${ }^{*}$ Condutividade elétrica do extrato de saturação.
} 
TABELA 5.43 (Continuação) - Combinação de atributos e níveis que definem as classes da carta de potencial agrícola (Fonte: Zuquette, 1993)

\begin{tabular}{|c|c|c|c|c|c|c|c|c|}
\hline & \multirow[b]{3}{*}{ Atributos } & \multirow{2}{*}{\multicolumn{7}{|c|}{ Classes }} \\
\hline \multirow[b]{2}{*}{ Componentes } & & & & & & & & \\
\hline & & \multicolumn{2}{|c|}{ Favorável } & \multicolumn{2}{|c|}{ Moderada } & \multicolumn{2}{|c|}{ Severa } & Restritiva \\
\hline Material & Saturação em Bases & \multicolumn{2}{|c|}{$>60$} & \multicolumn{2}{|c|}{$20-60$} & \multicolumn{2}{|c|}{$<20$} & $<10$ \\
\hline \multirow{2}{*}{$\begin{array}{c}\text { Condições } \\
\text { para Irrigação }\end{array}$} & \multirow{2}{*}{ Meio Físico / Águas } & \multirow{2}{*}{$\begin{array}{l}\text { Ade- } \\
\text { quado }\end{array}$} & \multirow{2}{*}{$\begin{array}{l}\text { Ade- } \\
\text { quado }\end{array}$} & Média & $\begin{array}{l}\text { Ade- } \\
\text { quado }\end{array}$ & \multirow{2}{*}{ Média } & \multirow{2}{*}{ Média } & \multirow{2}{*}{$\begin{array}{l}\text { Inedequado em } \\
\text { um dos fatores }\end{array}$} \\
\hline & & & & $\begin{array}{l}\text { Ade- } \\
\text { quado }\end{array}$ & Média & & & \\
\hline \multirow[b]{2}{*}{ Águas } & Drenabilidade & \multicolumn{2}{|c|}{$\overline{\text { Boa }}$} & \multicolumn{2}{|c|}{ Média } & \multicolumn{2}{|c|}{ Má } & Má \\
\hline & $\begin{array}{l}\text { Profundidade NA } \\
\text { (m) }\end{array}$ & \multicolumn{2}{|c|}{$>2$} & \multicolumn{2}{|c|}{$1-2$} & \multicolumn{2}{|c|}{$<1$} & $<0,5$ \\
\hline Relevo & Declividade & \multicolumn{2}{|c|}{$<8$} & \multicolumn{2}{|c|}{$8-12$} & \multicolumn{2}{|c|}{$>12$} & $>20$ \\
\hline \multirow{2}{*}{ Riscos } & Erosão & \multicolumn{2}{|c|}{ Baixo } & \multicolumn{2}{|c|}{ Médio } & \multicolumn{2}{|c|}{ Alto } & $\begin{array}{l}\text { Alto ou Muito } \\
\text { Alto }\end{array}$ \\
\hline & $\begin{array}{l}\text { Contaminação das } \\
\text { águas subterrâneas }\end{array}$ & \multicolumn{2}{|c|}{ Nulo a baixo } & \multicolumn{2}{|c|}{ Baixo } & \multicolumn{2}{|c|}{ Médio } & Alto \\
\hline
\end{tabular}

A sobreposição de todos os planos de informações no Idrisi ® 32 gerou um plano de informação novo (potencial agrícola) cujo os valores individuais dos pixels variavam desde 4 até 16 . Portanto, para pixels de valor igual a 4 todas as classes de adequabilidade, para os diferentes atributos (diferentes planos de informações), possuíam condição favorável, em contrapartida, para valores iguais a 16 elas eram todas restritas.

A etapa seguinte envolveu a reclassificação da imagem a partir da definição dos quatro intervalos nos quais as classes de aptidão estariam representadas, são eles:
a) de 4 a 6 para classe Favorável
b) de 7 a 9 para classe Moderada
c) de 10 a 13 para classe Severa
d) de 14 a 16 para classe Restritiva 


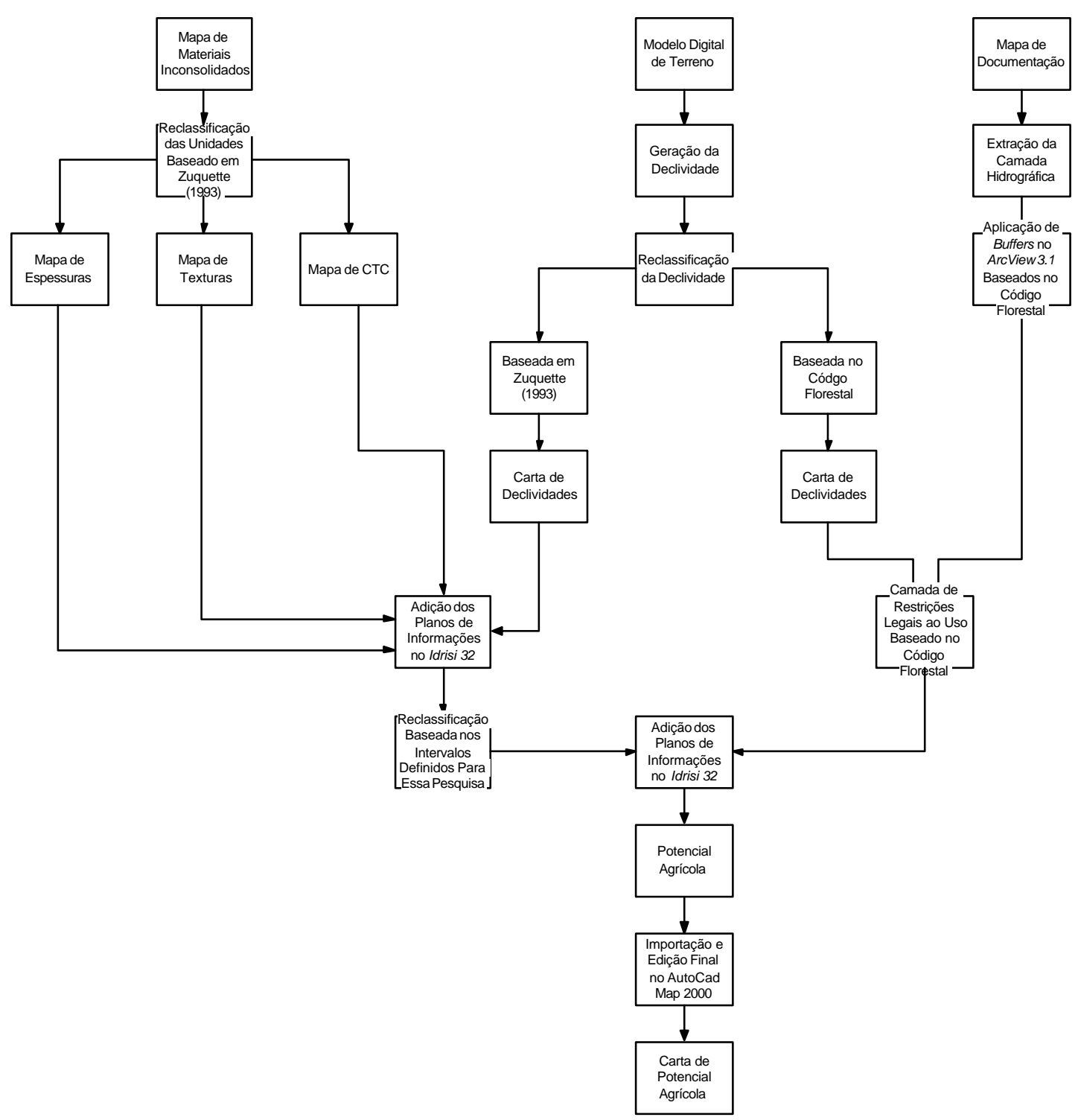

FIGURA 5.42 - Etapas seguidas para a construção da Carta de Potencial Agrícola.

Com o plano de informação de potencial agrícola reclassificado de treze (anteriormente variando entre 4 e 16) para quatro níveis (agora variando entre 1 e 4), o próximo passo envolveu a análise do Código Florestal (Lei no 4.471/65) para se determinar quais tipos de restrições legais poderiam existir e se aplicar na área em estudo. 
TABELA 5.44 - Classificação dos planos de informações obtidos por meio do mapa de materiais inconsolidados de acordo com suas classes de adequabilidade de potencial agrícola (de acordo com Zuquette, 1993).

\begin{tabular}{|c|c|c|c|}
\hline & Espessura & Textura & CTC \\
\hline Unidade 01 & Favorável & Severa & Restritiva \\
\hline Unidade 02 & Severa & Moderada & Moderada \\
\hline Sub-unidade 03a & Severa & Severa & Restritiva \\
\hline Sub-unidade 03b & Favorável & Severa & Moderada \\
\hline Unidade 04 & Moderada & Favorável & Severa \\
\hline Unidade 05 & Favorável & Moderada & Severa \\
\hline Unidade 06 & Moderada & Moderada & Favorável \\
\hline Unidade 07 & Favorável & Restritiva & Favorável \\
\hline Unidade 08 & Moderada & Favorável & Favorável \\
\hline Unidade 09 & Favorável & Favorável & Moderada \\
\hline Sub-unidade 10a & Severa & Favorável & Moderada \\
\hline Sub-unidade 10b & Moderada & Favorável & Moderada \\
\hline Sub-unidade 10c & Favorável & Favorável & Severa \\
\hline Sub-unidade 10d & Favorável & Favorável & Severa \\
\hline Unidade 11 & Favorável & Moderada & Moderada \\
\hline Unidade 12 & Favorável & Favorável & Severa \\
\hline Sub-unidade 13a & Severa & Favorável & Moderada \\
\hline Sub-unidade 13b & Moderada & Favorável & Moderada \\
\hline Sub-unidade 13c & Favorável & Favorável & Severa \\
\hline Unidade 14 & Favorável & Favorável & Severa \\
\hline Unidade 15 & Favorável & Favorável & Severa \\
\hline Sub-unidade 16a & Favorável & Favorável & Severa \\
\hline Sub-unidade 16b & Favorável & Favorável & Moderada \\
\hline Unidade 17 & Favorável & Moderada & Moderada \\
\hline Sub-unida de 18a & Severa & Favorável & Moderada \\
\hline Sub-unidade 18b & Favorável & Favorável & Moderada \\
\hline Unidade 19 & Favorável & Moderada & Severa \\
\hline Unidade 20 & Favorável & Favorável & Moderada \\
\hline Unidade 21 & Favorável & Favorável & Moderada \\
\hline
\end{tabular}



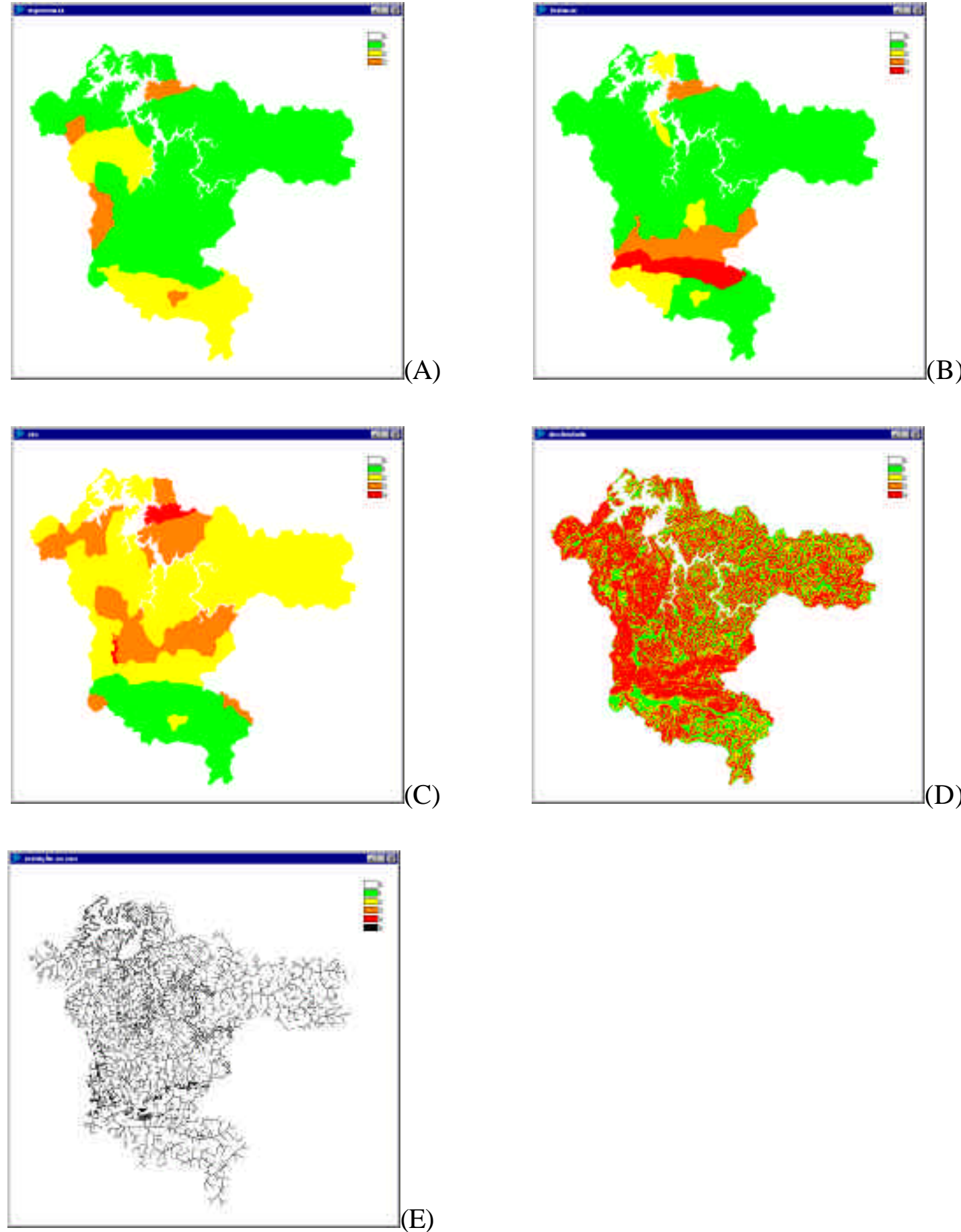

FIGURA 5.43 - Planos de informações utilizados no Idrisi ${ }^{\circledR} 32$ para gerar a carta de potencial agrícola. São eles: espessuras (A), texturas (B), CTC (C), declividades (D) e restrições legais baseado no Código Florestal (E). As cores verde, amarelo, laranja, vermelho e preto correspondem respectivamente aos potenciais favorável, moderado, severo, restritivo e restritivo baseado no Código Florestal. 
O Código Florestal Brasileiro foi utilizado pois a área estudada está localizada entre uma bacia hidrográfica que pertence a duas unidades da federação (Bacia do Rio Pardo), portanto nesse caso se preferiu adotar um mesmo critério. Além disso, quaisquer resoluções legislativas estaduais e municipais específicas provenientes, tanto em São Paulo quanto em Minas Gerais, jamais poderiam diminuir as áreas destinadas a preservação ambiental amparadas pelo Código Florestal.

O Código Florestal regulamenta:

Art. $2^{\circ}$ - Consideram-se de preservação permanente, pelo só efeito desta lei, as florestas e demais formas de vegetação natural situadas:

a) ao longo dos rios ou de qualquer curso de água desde seu nível mais alto em faixa marginal cuja largura mínima seja:

1) de 30 (trinta) metros para cursos de água de menos de 10 (dez) metros de largura;

2) de 50 (cinqüenta) metros para cursos de água que tenham de 10 (dez) a 50 (cinqüenta) metros de largura;

3) de 100 (cem) metros para os cursos de água que tenham de (cinqüenta) a 200 (duzentos) metros de largura;

4) de 200 (duzentos) metros para os cursos de água que tenham de 200 (duzentos) a 600 (seiscentos) metros de largura;

5) de 500 (quinhentos) metros para cursos de água que tenham largura superior a 600 (seiscentos) metros;

b) ao redor das lagoas, lagos ou reservatórios de águas naturais ou artificiais;

c) nas nascentes, ainda que intermitentes e nos chamados olhos d'água, qualquer que seja a sua situação topográfica, num raio mínimo de 50 (cinqüenta) metros de largura;

d) no topo de morros, montes, montanhas e serras;

e) nas encostas ou partes destas com declividade superior a $45^{\circ}$, equivalente a 100 $\%$ as linha de maior declive;

f) nas restingas, como fixadoras ou estabilizadoras de mangues; 
g) nas bordas dos tabuleiros ou chapadas, a partir da linha de ruptura de relevo, em uma faixa nunca inferior a 100 (cem) metros em projeções horizontais;

h) em atitudes superiores a 1.800 (mil e oitocentos) metros, qualquer que seja a vegetação

Parágrafo Único - No caso de áreas urbanas, assim entendidas as compreendidas nos perímetros urbanos definidos por lei municipal, e nas regiões metropolitanas e aglomerações urbanas, em todo território abrangido, observar-se-á o disposto nos respectivos planos diretores e leis de uso de solo, respeitados os princípios e limites que se refere este artigo

Art. $10^{\circ}$ - Não é permitida a derrubada de florestas situadas em áreas de inclinação entre 25 e 45 graus, só sendo nelas tolerada a extração de toros quando em regime de utilização racional, que vise a rendimentos permanentes.

Para carta de potencial agrícola ficou estabelecido que seriam adotados:

I. O conteúdo do ítem 1 da alínea "a" do artigo $2^{0}$ para todos os canais de drenagem mapeados (presentes no mapa de documentação).

II. Cem metros para a resolução definida pelo conteúdo da alínea "b" do artigo $2^{\circ}$ (sugestão).

III. O conteúdo da alínea "e" do artigo $2^{\circ}$.

IV. O conteúdo do artigo $10^{\circ}$. 
O conteúdo da alínea "c" do artigo $2^{0}$ não foi adotado nessa pesquisa pela dificuldade de localização dos inúmeros olhos d'água, nascentes permanentes e intermitentes. Contudo, uma vez tais locais identificados pelo(s) usuário (s) desse produto cartográfico geotécnico, este(s) deve(m) estar informado(s) que as áreas situadas ao redor de $50 \mathrm{~m}$ estão sobre preservação permanente, portanto não devendo ser utilizadas com finalidade agrícola independente de serem consideradas de aptidão restritiva, severa, moderada ou até mesmo favorável pela carta de potencial agrícola.

Superadas essas etapas, os passos seguintes envolveram a delimitação dos setores com restrições legais, adotados para carta de potencial agrícola a partir do Código Florestal, utilizando os SIG's ArcView ${ }^{\circledR} 3.1$ e Idrisi ${ }^{\circledR} 32$.

Por meio do ArcView 3.1 foi possível selecionar os intervalos de 30 e $100 \mathrm{~m}$ respectivamente para as áreas marginais aos canais da rede de drenagem e ao lago da Hidroelétrica de Caconde (função buffer). No Idrisi 32, por sua vez, novamente reclassificou-se as declividades (geradas a partir do MDT) e dividiu-se em dois intervalos. O primeiro deles corresponde aos intervalos restritivos estabelecidos pelos artigos $2^{\circ}$ e $10^{\circ}$. O segundo refere-se aos locais não especificados pelos artigos, ou seja áreas do terreno com declividades inferiores a 25 graus $(47 \%)$.

O estágio seguinte de construção desse documento cartográfico abrangeu a adição dos dois planos de informações de caráter restritivo (rede hidrográfica e declividades), sobre o plano de informação contendo o potencial agrícola no Idrisi 32.

A ultima etapa de construção da carta de potencial agrícola envolveu a importação do arquivo do Idrisi ${ }^{\circledR} 32$ no formato BMP por parte do AutoCad Map 2000 e consequentemente a realização da edição no mesmo programa. O resultado da distribuição das classes dessa carta podem ser apreciadas na Tabela 5.45. 
TABELA 5.45 - Resultados da distribuição das classes que compõem a Carta de Potencial Agrícola

\begin{tabular}{|c|c|c|}
\hline $\begin{array}{|lll|}\text { Classe de } & \text { Potencial } \\
\text { Agrícola } & & \\
\end{array}$ & $\begin{array}{l}\text { Total de Área Ocupada } \\
\text { em km }^{2}\end{array}$ & $\begin{array}{l}\text { Percentual da } \\
\text { Ocupada }\end{array}$ \\
\hline Favorável & 85,62 & 17,75 \\
\hline Moderada & 260,25 & 53,96 \\
\hline Severa & 47,39 & 9,83 \\
\hline Restritiva & 2,14 & 0,44 \\
\hline $\begin{array}{lll}\text { Setores } & \text { com } & \text { restrições } \\
\text { legais } & & \\
\end{array}$ & 86,89 & 18,02 \\
\hline TOTAL & 482,29 & 100,00 \\
\hline
\end{tabular}

\subsection{Sistemas de Bancos de Dados Associados aos Documentos Cartográficos Produzidos em Ambiente SIG}

Tendo em vista o grande número de informações produzidas nessa pesquisa, sentiu-se a necessidade de organizá-las de forma que o(s) usuário(s) futuro(s) $\operatorname{possa}(\mathrm{m})$ acrescer, recuperar, atualizar ou até mesmo remover qualquer registro de informação a medida que se faça necessário.

Desta forma, optou-se por se trabalhar com um SIG, pois este é capaz de associar um ou mais sistemas de banco de dados a um ou mais documentos cartográficos (mapas e cartas) de forma que interajam conjuntamente promovendo assim grande rapidez e confiabilidade ao(s) usuário(s) que o esteja utilizando.

Para essa pesquisa o SIG adotado foi o ArcView ${ }^{\circledR} 3.1$ pois esse foi capaz de importar e manipular os mapas e cartas produzidos no AutoCad Map ® 2000 (mapas de documentação, substrato rochoso, materiais inconsolidados e landforms) Idrisi ${ }^{\circledR}$ 32 (cartas de declividade e potencial agrícola) e Envi ${ }^{\circledR} 3.2$ (mapa de uso e ocupação). 


\subsubsection{Construção do Banco de Dados Baseados em Registros Pontuais}

A construção do banco dos registros pontuais realizados nesse trabalho envolveu o desenvolvimento de três tabelas em formato DBF no Microsoft Excel e posterior integração ao sistema de banco de dados do ArcView ® 3.1.

As tabelas são referentes às informações obtidas através de pontos vis itados no campo (62 pontos), pontos visitados acrescidos de resultados de ensaios realizados em amostras deformadas e indeformadas de materiais inconsolidados (52 pontos) e informações pré-existentes resultante da consulta do banco de dados digital (Sistema MICROSIR), checadas no campo, provenientes da CPRM (20 pontos).

A tabela de pontos visitados foi obtida a partir da consulta dos registros da caderneta de campo. Desse modo, foram estabelecidos como campos (colunas) da tabela: número do ponto observado; UTM (E-W); UTM (N-S); tipo de landform e tipo de substrato rochoso e imagem (foto quando existir).

É importante frisar que a caderneta de campo possui mais informações que as presentes nos campos da tabela (cor, origem e textura dos materiais inconsolidados; mineralogia do substrato rochoso, presença de eventos geodinâmicos, padrão de uso do meio físico, etc). Portanto, podendo essas serem acrescentadas à medida que se queira ou se faça necessário.

Para a tabela referente aos pontos amostrados, além dos campos contidos na tabela anterior, foram adicionados os resultados dos ensaios realizados com amostras deformadas e indeformadas nos materiais inconsolidados. Dessa forma, foram acrescentados os campos de massa específica dos sólidos $\varphi_{\mathrm{s}}$ ); os percentuais de argila, silte, areia, a imagem da curva granulométrica produzida pelo ensaio de análise granulométrica, massa específica dos sólidos $\left(\rho_{\mathrm{s}}\right)$, massa específica seca $\left(\rho_{\mathrm{d}}\right)$, índice de vazios (e), porosidade $(n)$, grau de saturação $\left(S_{r}\right)$, capacidade de troca catiônica (CTC) total, capacidade de troca catiônica (CTC) da fração argila, superfície específica (SE) total, valor de adsorção de azul de metileno para os solos $(\mathrm{Vb})$, valor de adsorção de azul de metileno para a fração argila dos solos (Acb) 
Os pontos que formam a tabela de dados pré-existentes foram obtidos por meio da consulta ao banco de dados da CPRM, chamado de MICROSIR. Tal sistema disponibiliza aos usuários informações acerca de afloramentos geológicos, análises geoquímicas, ocorrências minerais e poços para água subterrânea baseados nos trabalhos desenvolvidos pela CPRM desde sua criação em todo o território nacional.

Especificamente para a área em estudo, os dados pré-existentes recuperados referem-se somente as fichas de campo utilizadas por Cavalcante et al. (1979). Nessas são apresentadas informações relativas à localização, ao relevo, à vegetação, aos solos, à descrição geológica e à classificação estratigráfica.

A tabela de dados pré-existentes, além de contar com a verificação em campo da descrição de seus pontos, teve seus campos complementados de acordo com a tabela de pontos visitados.

As tabelas construídas foram integradas ao sistema de banco de dados do ArcView ® 3.1 através do módulo de visualização (view) acessado a partir do gerenciador de projetos por meio do comando VIEW $\rightarrow$ ADD EVENT THEME.

É importante frisar que em situações que envolvam um grande número de campos (colunas da tabela) e principalmente registros (linhas da tabela) é preferível que o sistema de banco de dados seja implementado fora do ArcView 3.1.

Isso ocorre porque softwares específicos como Microsoft Access facilitam a entrada de dados através da construção de formulários específicos para cada tipo de situação, portanto, permitem aos usuários preencher os campos de modo mais eficiente e rápido. Os sistemas de bancos de dados montados externamente podem ser facilmente integrados ao ArcView 3.1 por meio da função SQL Connect.

\subsubsection{Construção do Banco de Dados a Partir dos Documentos Cartográficos Elaborados}

Como já dito anteriormente todos os mapas e cartas produzidos nessa pesquisa foram integrados ao sistema de bancos de dados do ArcView 3.1. Com relação aos documentos que foram produzidos no formato raster como o mapa de uso e ocupação no Envi 3.2, e as cartas de declividade e potencial agrícola pelo Idrisi 32, os respectivos softwares dispunham de opções que permitiram a exportação para o ArcView 3.1. 
Desse modo esses documentos cartográficos foram convertidos em planos de informações do tipo vetorial, permitindo assim a formação de polígonos associados a um sistema de banco de dados pela aglutinação de pixels vizinhos com o mesmo identificador.

Com relação aos mapas digitalizados no AutoCad Map 2000 (formato vetorial), os planos de informação foram inportados para o ArcView GIS 3.1 através do módulo de visualização (view) acessado a partir do gerenciador de projetos (comando: VIEW $\rightarrow$ ADD THEME).

Especificamente para o mapa de documentação, além dos planos de informação presentes no documento cartográfico, foram adicionados a tabela relativas aos pontos visitados no campo, aos pontos visitados acrescidos de resultados de ensaios realizados e as informações pré-existentes (Figura 5.44).

Em complemento a essa etapa de trabalho foi utilizado a ferramenta hot link do ArcView GIS 3.1, pois essa permite que sejam feitas ligações entre entidades de um nível (pontos, linhas e polígonos) com diversos tipos de formatos de arquivos (imagens, textos ou outros arquivos do ArcView). Desse modo foi possível, por exemplo, adicionar fotografias retiradas no campo às diversas unidades mapeadas presentes nos documentos cartográfico produzidos.

\subsubsection{Alguns Exemplos de Operações que Podem Ser Realizadas Utilizando os Bancos de Dados e os Documentos Cartográficos Produzidos}

As possibilidades de análise e manipulação de um banco em um ambiente de sistema de informações geográfica são muito amplas. Entretanto, deseja-se apresentar nessa sessão, a título de exemplo, três dessas operações que podem ser facilmente executadas no SIG por qualquer usuário a partir da sequiência de comandos descritos.

A primeira dessas é a seleção de entidades a partir do documento de visualização (Mapa de Landforms). Através dessa ferramenta o sistema de informação geográfica permite que o usuário consiga obter informações a cerca de qualquer entidade presente no mapa de landforms (pontos, retas ou polígonos) na forma de tabela com um simples clique do cursor. 


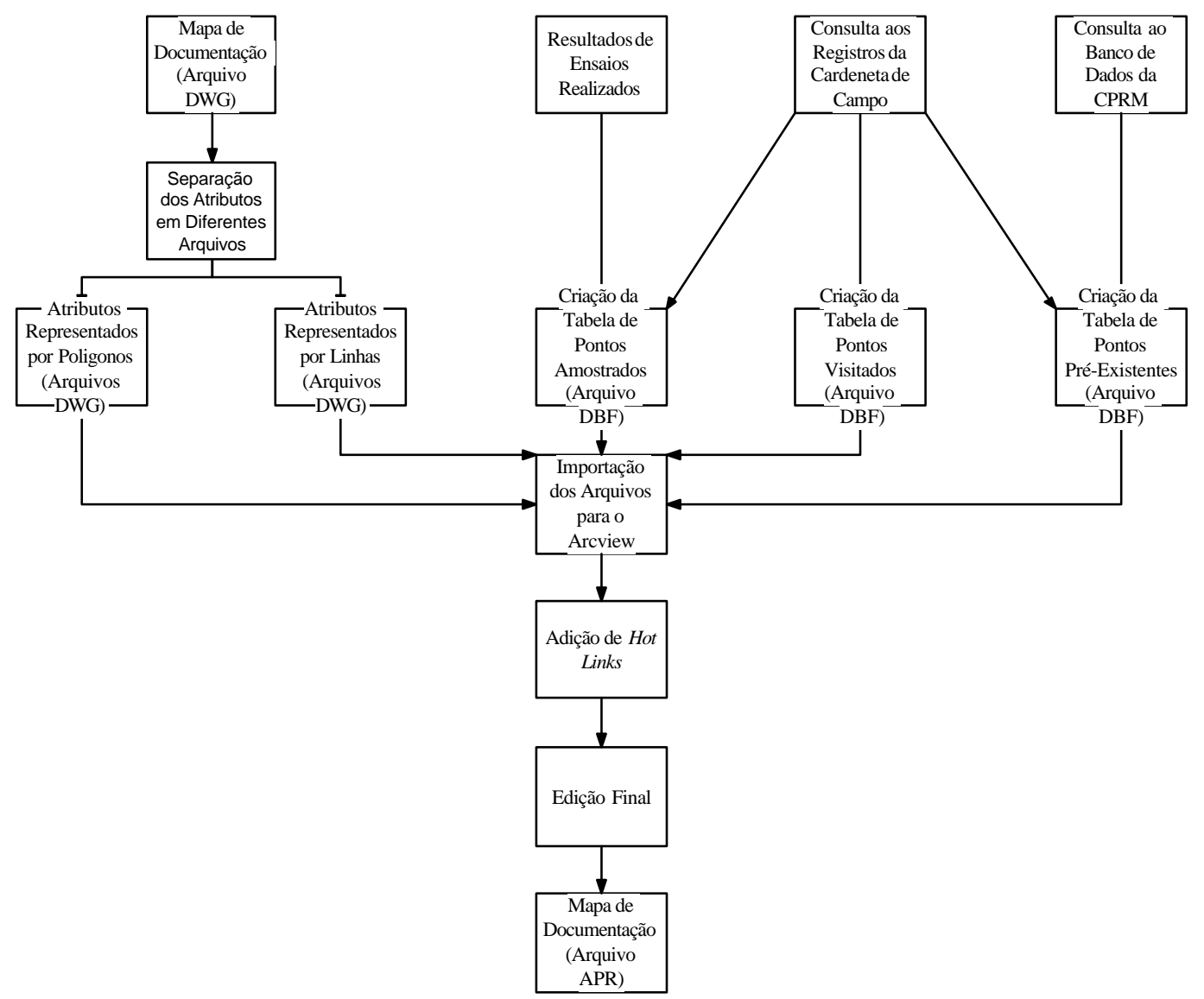

FIGURA 5.44 - Etapas seguidas para a construção do mapa de documentação no ArcView GIS 3.1.

Uma vez que o documento de visualização está atrelado a um banco de dados contendo suas informações, o programa exige que o nível (shape) escolhido esteja selecionado, sendo em seguida acionado o botão indentify sob a entidade desejada (Figura 5.45).

Dentre as operações que o SIG realiza, utilizando banco de dados, uma das mais interessantes é o cálculo das dimensões das linhas e polígonos que compõem o documento de visualização.

A aplicação desse tipo de ferramenta é bastante conveniente principalmente no que se refere a análise morfométrica de bacias. Desse modo, são estabelecidos com facilidade parâmetros como: Relação de bifurcação $\left(R_{b}\right)$, Relação entre o comprimento médio dos canais de cada ordem $\left(\mathrm{RL}_{\mathrm{m}}\right)$, Índice de Circularidade (Ic), Densidade hidrográfica (Dh), dentre outros. 


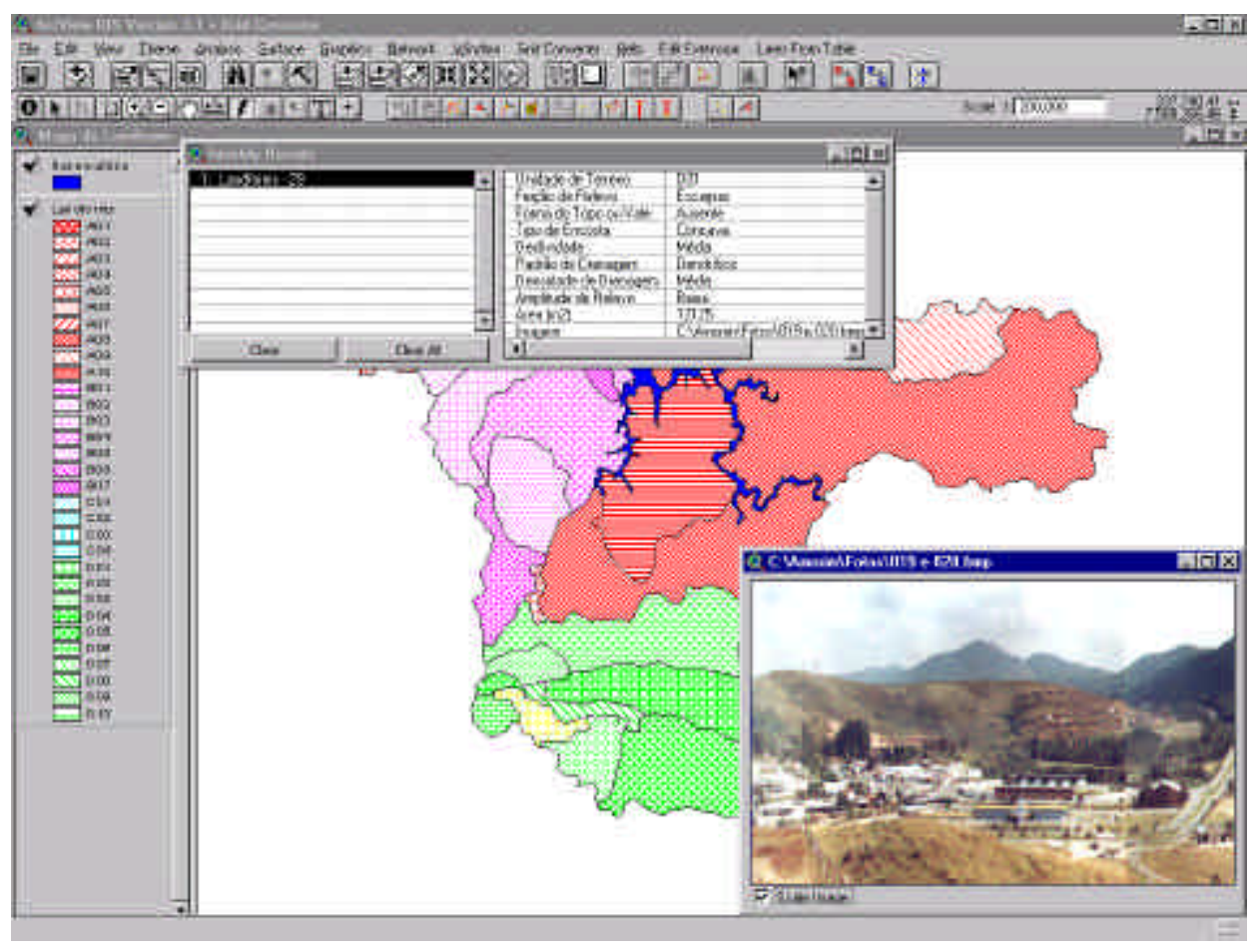

FIGURA 5.45 - Identificação das Unidades de Terreno com auxilio de hot link.

Diversos estudos geológico-geotécnicos vem se servindo de análises morfométricas temporais em bacias no Estado de São Paulo (Simões, 1999; Collares, 2000; Silva 2000). Kso se deve principalmente ao fato da rede de drenagem se constituir em um excelente geo-indicador.

O cálculo do comprimento de cada canal da bacia é realizado dentro da tabela correspondente ao shape (nível) da rede hidrográfica (presente no mapa de documentação). Assim, a partir da criação de um novo campo na tabela (comprimento), e utilizando a função field calculator através do comando: [Shape].ReturnLength, o Arcview GIS 3.1 estabelece para cada canal previamente digitalizado no CAD (Figura 5.2) o seu comprimento medido em metros (Figura 5.46).

O terceiro exemplo de operação utilizando o banco de dados é realizada por meio da seleção de um grupo de entidades envolvendo um ou mais campos das tabelas numéricos ou alfanuméricos. Desse modo, é possível através de uma simples pesquisa determinar no documento de visualização qual(is) polígono(s), reta(s) ou ponto(s) que atendem a uma determinada condição. 


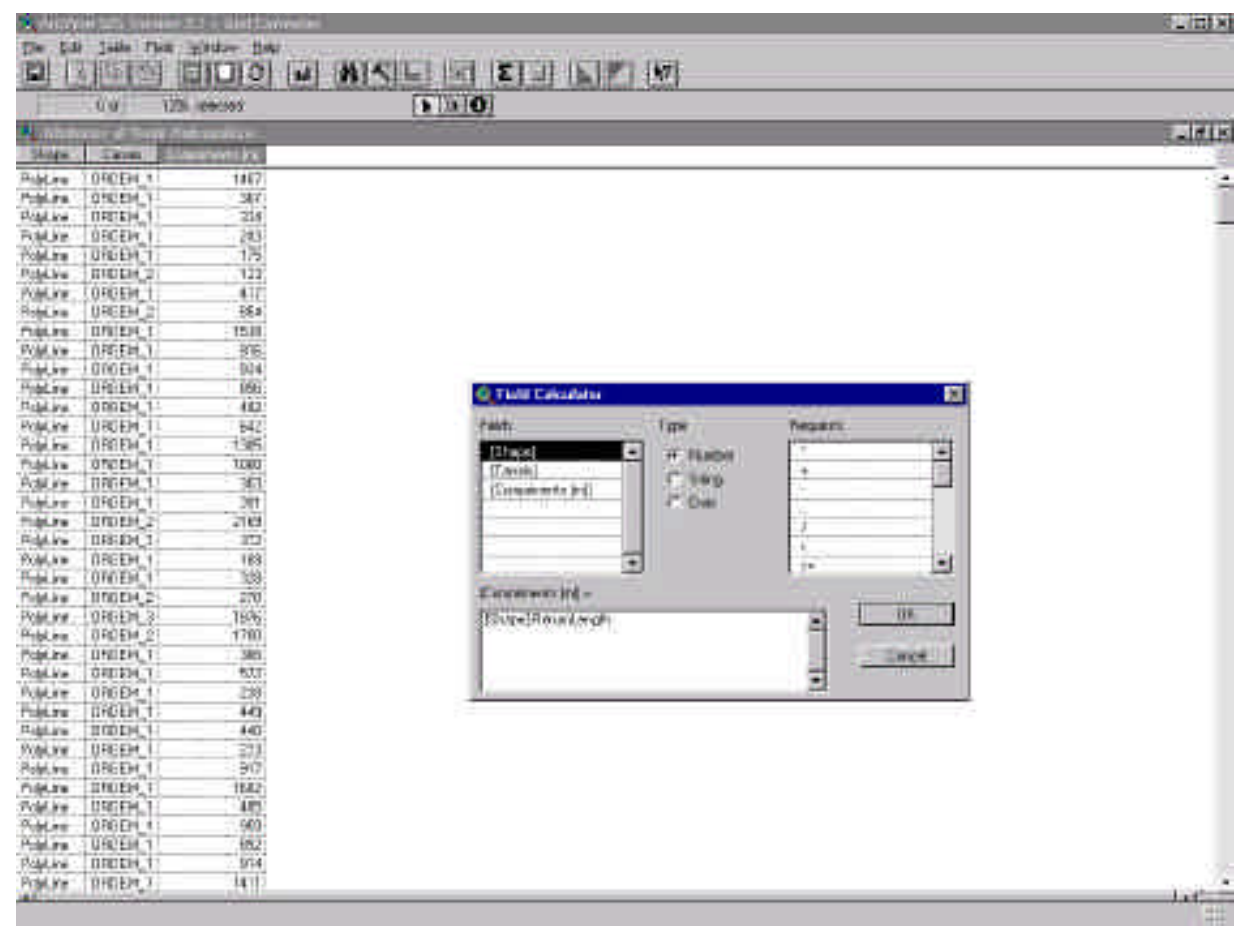

FIGURA 5.46 - Cálculo do comprimento dos canais fluviais através da função field calculator.

Para ilustrar tal operação consideremos duas situações. Na primeira suponhase que se queira determinar em quais pontos amostrados a fração argilosa predomina sobre a soma das outras (> 50\%), associando ainda a essa condição, um resultado para a massa específica de sólidos maior que a do quartzo $\left(2,650 \mathrm{~g} / \mathrm{cm}^{3}\right)$.

O primeiro passo é escolher no documento de visualização (mapa de documentação) o shape desejado, no caso, pontos amostrados. Por fim, através da função query builder (THEME $\rightarrow$ QUERY BUILDER) e utilizando a linha de comando: ([\% de Argila] > 50) and ([MES] > 2.650) todos os pontos que atenderem essa condição serão selecionados (Figura 5.47).

Para confirmar se realmente essa qualidade foi atendida, basta examinar a Figura 5.48 e nela comprovar que os pontos P025-A18, P035-A25, P040-A26, P053A31, P063-A37, P069-A40, P070-A41, P116-A48, P118-A49, P126-A52, P131-A56, P133-A58 selecionados são os que respeitam essa condição.

Para segunda, imagine-se que o usuário queira localizar de modo preliminar os locais com tendência a apresentar materiais inconsolidados pouco espessos, podendo estes, estar associados a substrato rochoso aflorante. 


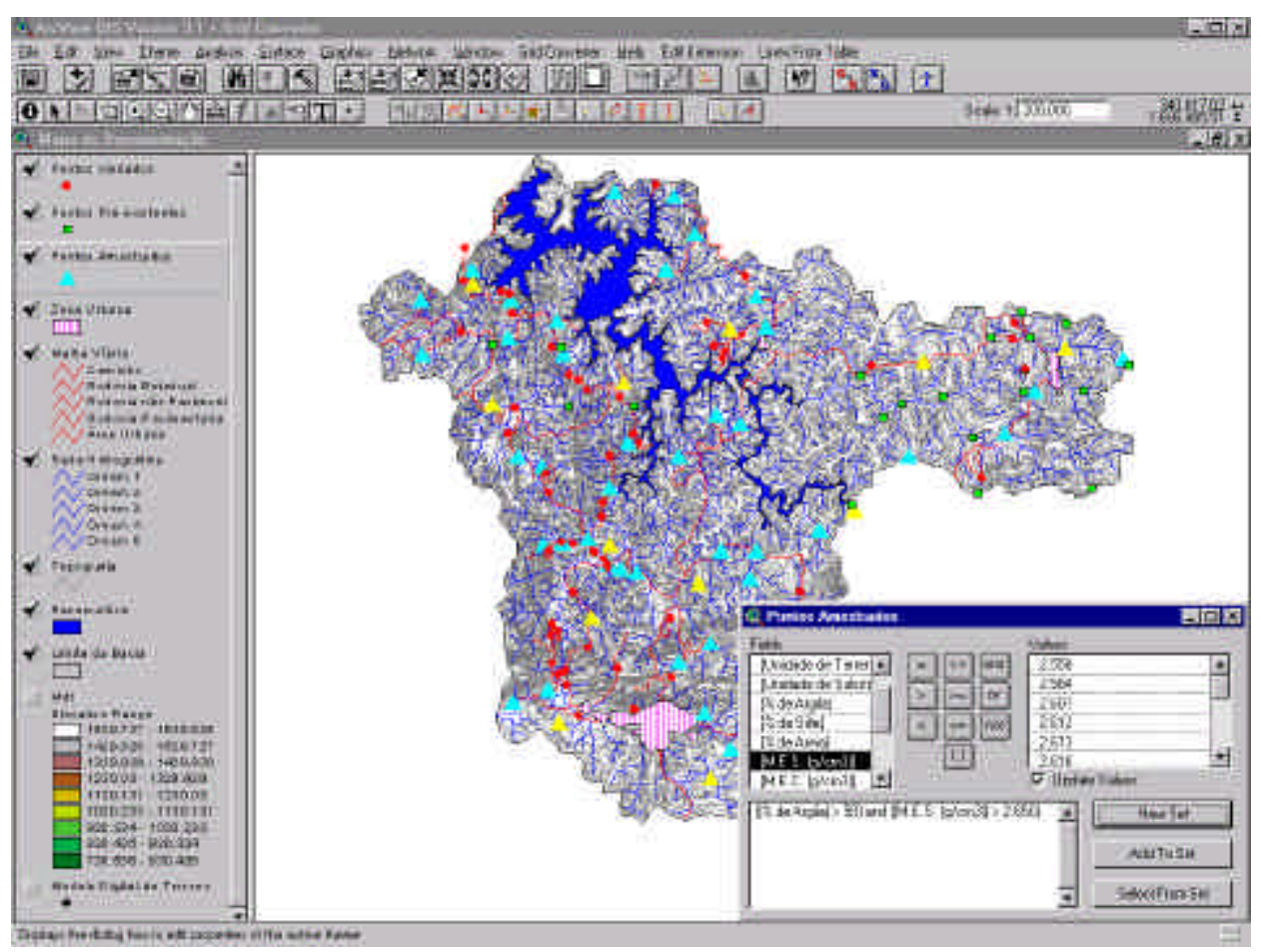

FIGURA 5.47 - Função query builder utilizada na seleção de entidades do mapa de documentação (triângulos destacados em amarelo).

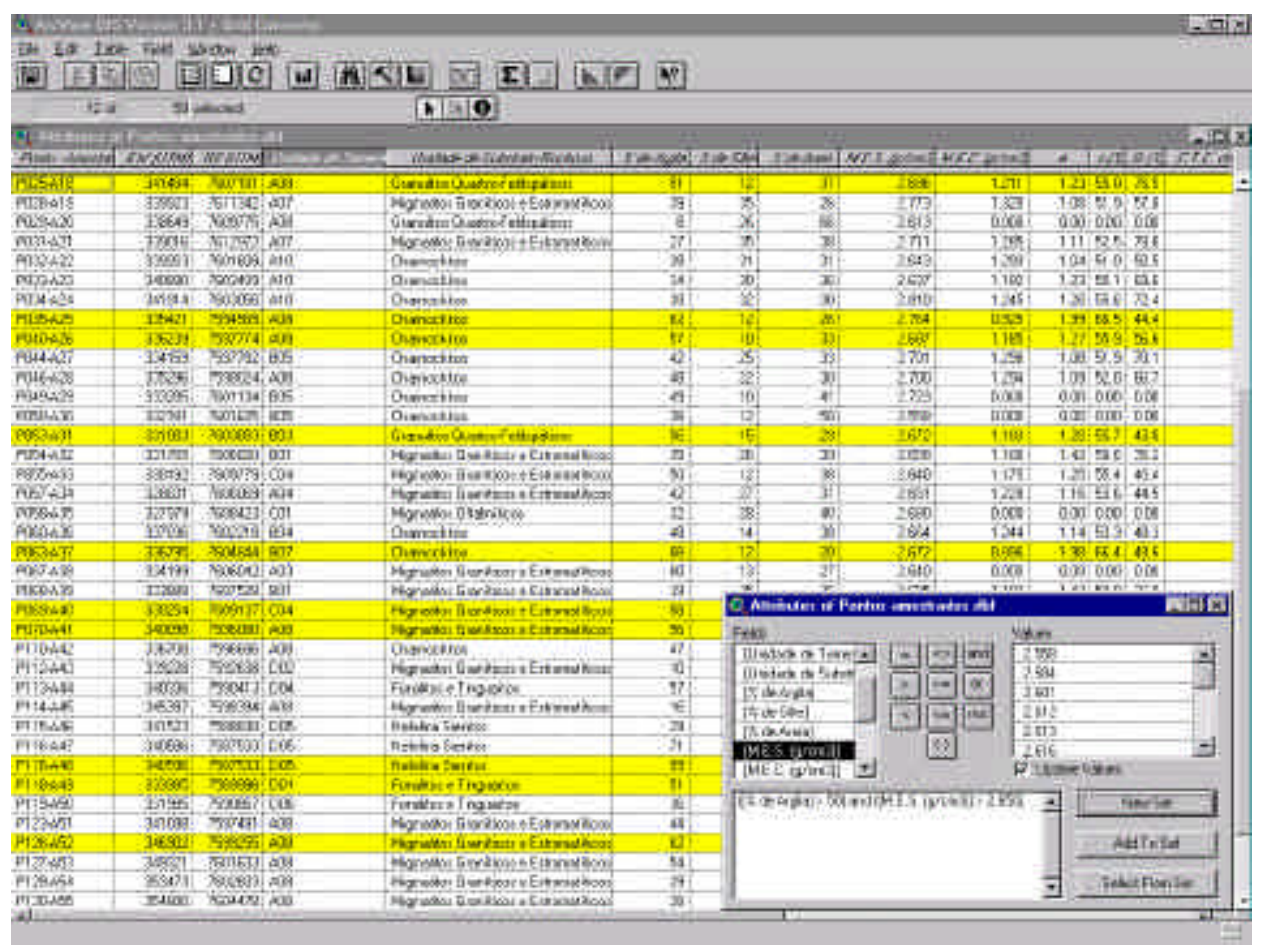

FIGURA 5.48 - Entidades numéricas selecionadas na tabela de pontos amostrados a partir da função query builder. 
De acordo com Lollo (1996) formas que apresentam encostas íngremes ou abruptas devem apresentar perfis menos profundos de materiais inconsolidados, devido a intensidade de processos erosivos. Desse modo, o usuário pode assumir que as Unidades de Terreno formadas por escarpas com encostas retilíneas e de alta declividade são excelentes representantes dessas condições.

Utilizando o mapa de landforms através da função query builder (THEME $\rightarrow$ QUERY BUILDER) mais a linha de comando: ([Feição de Relevo] = "Escarpas") and $($ [Tipo de Encosta $]=$ "Retilínea") and $($ [Declividade $]=$ "Alta") todos os registros que atenderem essa condição serão selecionados (Figura 5.49) tanto quanto as unidades A04, B06, C01, C04 e D04 no mapa de landforms (Figura 5.50). 


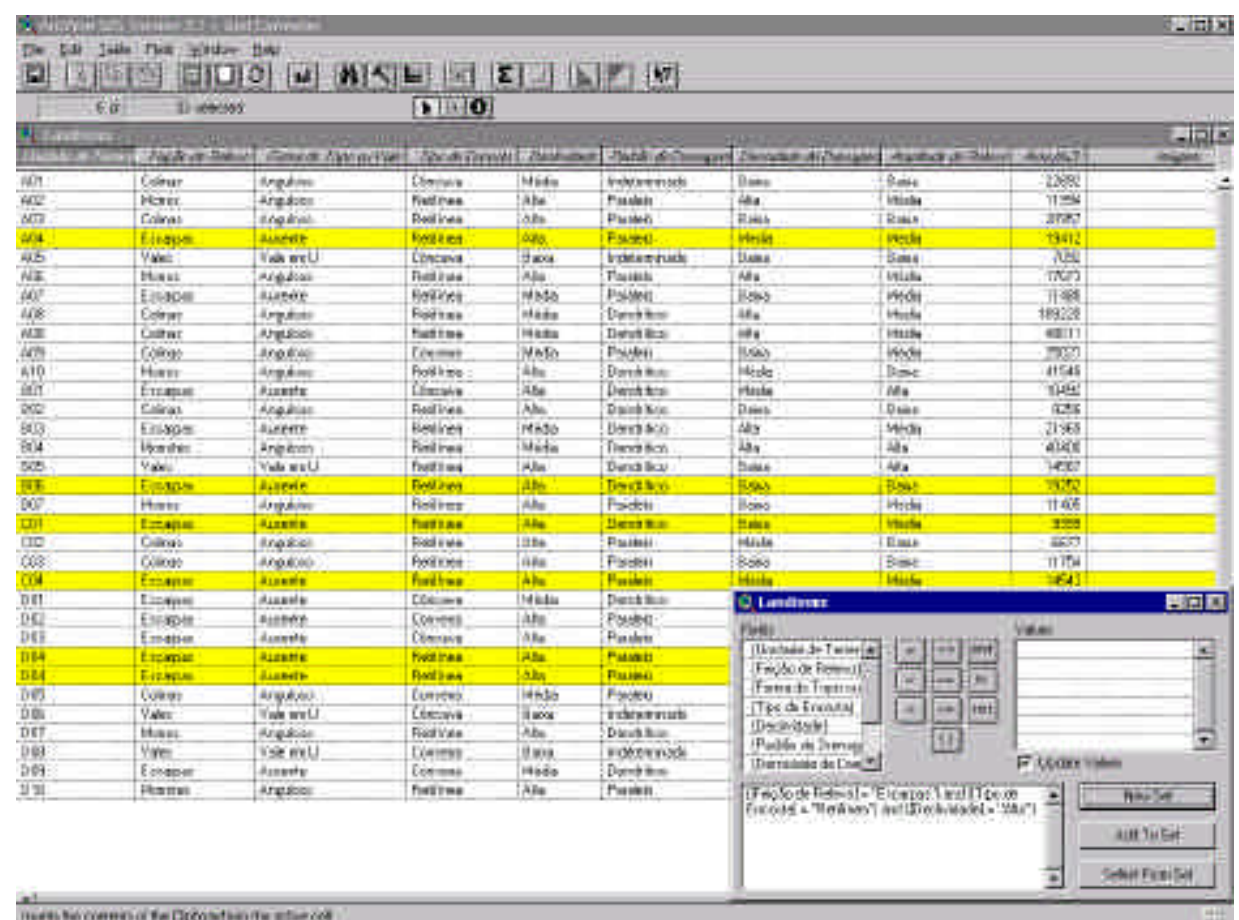

FIGURA 5.49 - Unidades de Terreno (entidades alfanuméricas) selecionadas na tabela de landforms a partir da função query builder

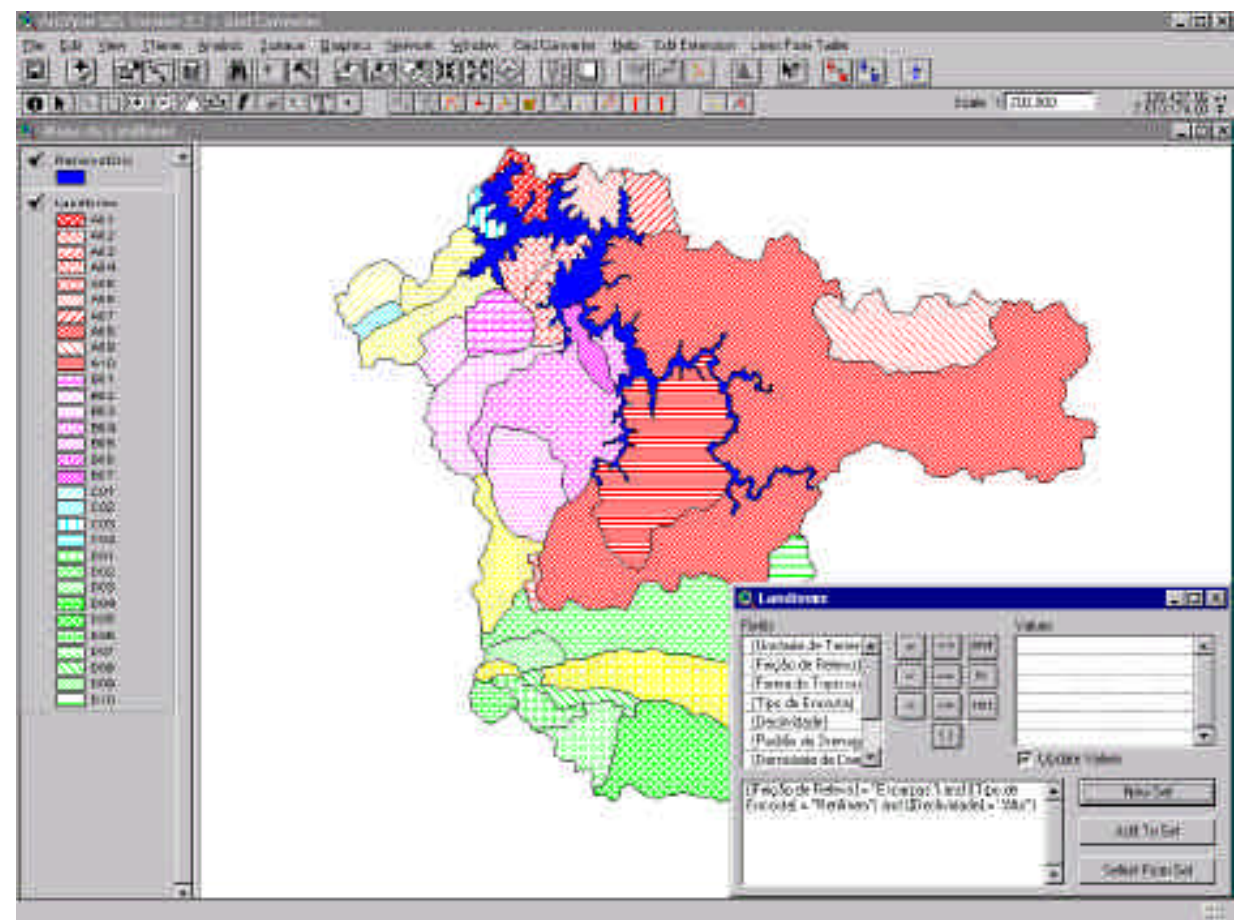

FIGURA 5.50 - Função query builder utilizada na seleção de Unidades de Terreno no mapa de landforms (polígonos destacados em amarelo). 


\section{CAPÍTULO 6 - CARTA DE ZONEAMENTO GEOAMBIENTAL}

\subsection{Definição e Finalidades da Carta de Zoneamento Geoambiental}

A Carta de Zoneamento Geoambiental (ANEXO VIII) nessa pesquisa deve ser compreendida a partir de duas concepções. A primeira delas atribui como sua principal finalidade a de delimitar na área estudada setores que apresentem, quando analisados individualmente, homogeneidade quanto aos aspectos do meio físico levantados, em termos geomorfológicos (carta de declividades e mapa de landforms), geológicos (mapa de substrato rochoso), de "solos" (mapa de materiais inconsolidados) e de suas aptidões (carta de potencial agrícola).

A segunda concepção prevê para a carta geoambiental, quando avaliada na sua totalidade, um comportamento heterogêneo de modo que cada um de seus setores (unidades geoambientais) apresentem características bem particulares relacionadas aos componentes do meio físico avaliados, desse modo podendo ser utilizados como unidades de planejamento territorial e de avaliação ambiental.

\subsection{Elaboração da Carta de Zoneamento Geoambiental}

A confecção da carta foi realizada por meio de uma reclassificação das unidades de terreno (mapa de landforms) a partir da análise de agrupamentos dos atributos do meio físico presentes nos documentos cartográficos geotécnicos produzidos (Figura 6.1). 


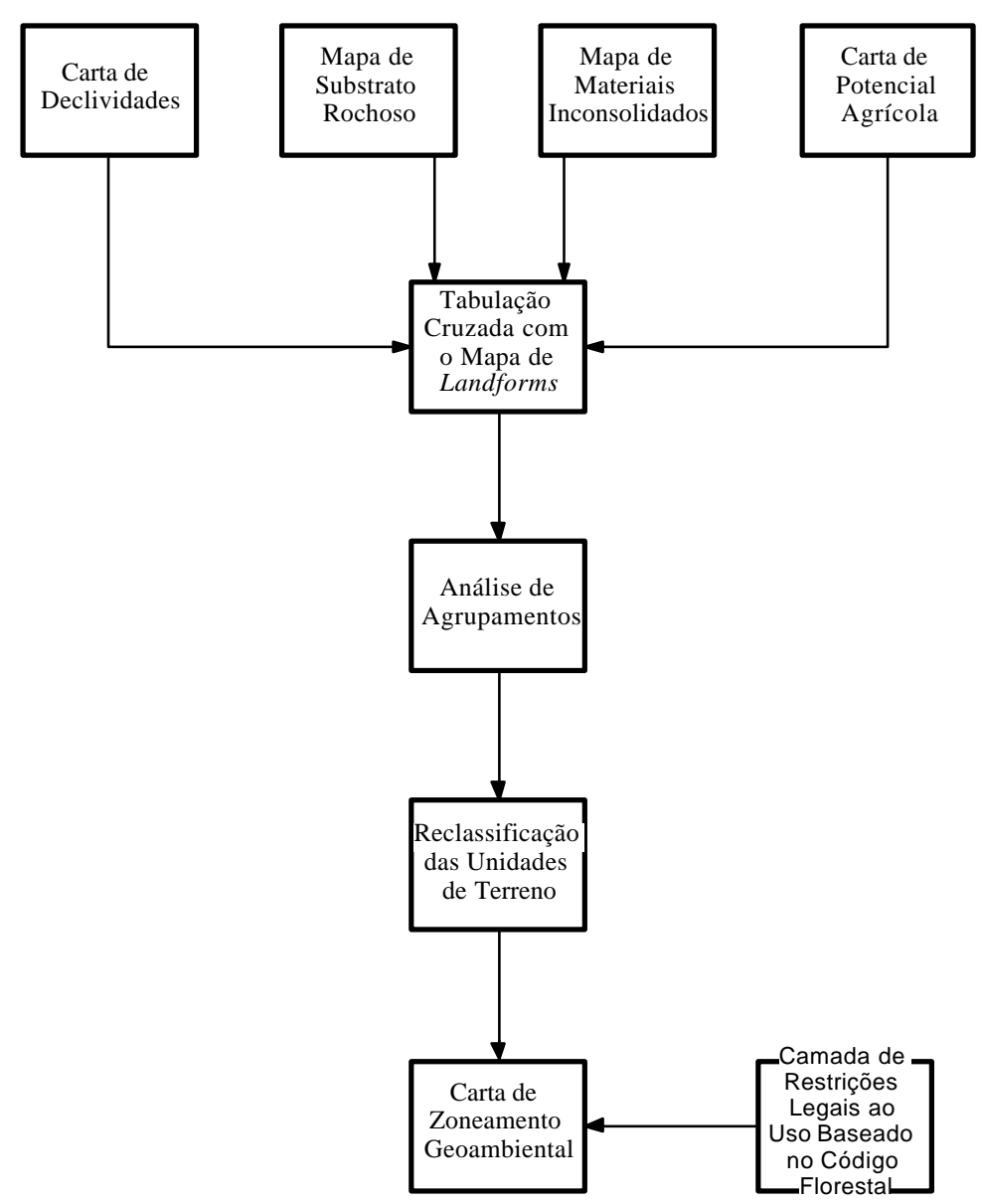

FIGURA 6.1 - Etapas seguidas para a construção da Carta de Zoneamento Geoambiental.

As variáveis analisadas referem-se aos percentuais em área ocupadas em cada unidade de terreno pelas classes/unidades de declividades (9 variáveis), de potencial agrícola (5 variáveis), de substrato rochoso (6 variáveis) e de materiais inconsolidados (21 variáveis). Tais áreas foram obtidas utilizando o Idrisi 32 através da função de tabulação cruzada (Comando: ANALYSIS $\rightarrow$ DATABASE QUERY $\rightarrow$ CROSSTAB).

Os resultados fornecidos pela tabulação cruzada encontram- se no ANEXO IX que conta ainda com outras informações relativas às unidades de terreno obtidas pela análise do MDT da área (altimetria) e dos canais de drenagem (consulta ao banco de dados no ArcView 3.1). 
A análise de agrupamentos dos componentes do meio físico foi executada utilizando-se o STATISTICA® 5.5 por meio da técnica de agrupamento pareado igualmente ponderado, empregando a medida de distância euclidiana. Este procedimento foi adotado, pois tal técnica se mostrou muito apropriada à geração de agrupamentos que apresentam variáveis com a mesma dimensão, conforme mostra a análise de agrupamentos dos materiais inconsolidados na sessão 5.4 (Figura 5.14) realizada somente a partir de classes texturais (percentuais de argila, silte e areia).

O dendograma produzido com as 41 variáveis utilizadas aponta para possibilidades de agrupamentos que variam de 31 , quando a distância euclidiana é 0 , a até dois grupos para uma distância de 205,64 (Figura 6.2).

A partir desses resultados ficou estabelecido para esta pesquisa que a análise de agrupamentos somente seria utilizada na reclassificação das unidades de terreno se atendesse as seguintes condições:

a) Feições de relevo do tipo vales não poderia estar associadas a outros tipos de feições de relevo, exceto a outros vales, uma vez que apresentam características bem particulares de declividades, de amplitudes de relevo, de ausência de topos, de forma (vales abertos ou fechados), de condições hidrológicas, de materiais inconsolidados (muitas vezes compostos exclusivamente por materiais retrabalhados), etc;

b) As unidades de terreno agrupadas deveriam apresentar pouca heterogeneidade em relação aos atributos do meio físico envolvidos, principalmente no que se refere aos seus substratos rochosos e materiais inconsolidados;

c) As unidades geoambientais, obtidas pela a análise de agrupamentos, deveriam ser reagrupas de modo a manterem a ausência de qualquer agrupamento utilizando as mesmas condições de contorno estabelecidas para as unidades de terreno.

Analisando tais considerações, observa-se no dendograma das unidades de terrenos (Figura 6.2) que a distância euclidiana com valor igual a 60 atende a todas as condições citadas anteriormente. 


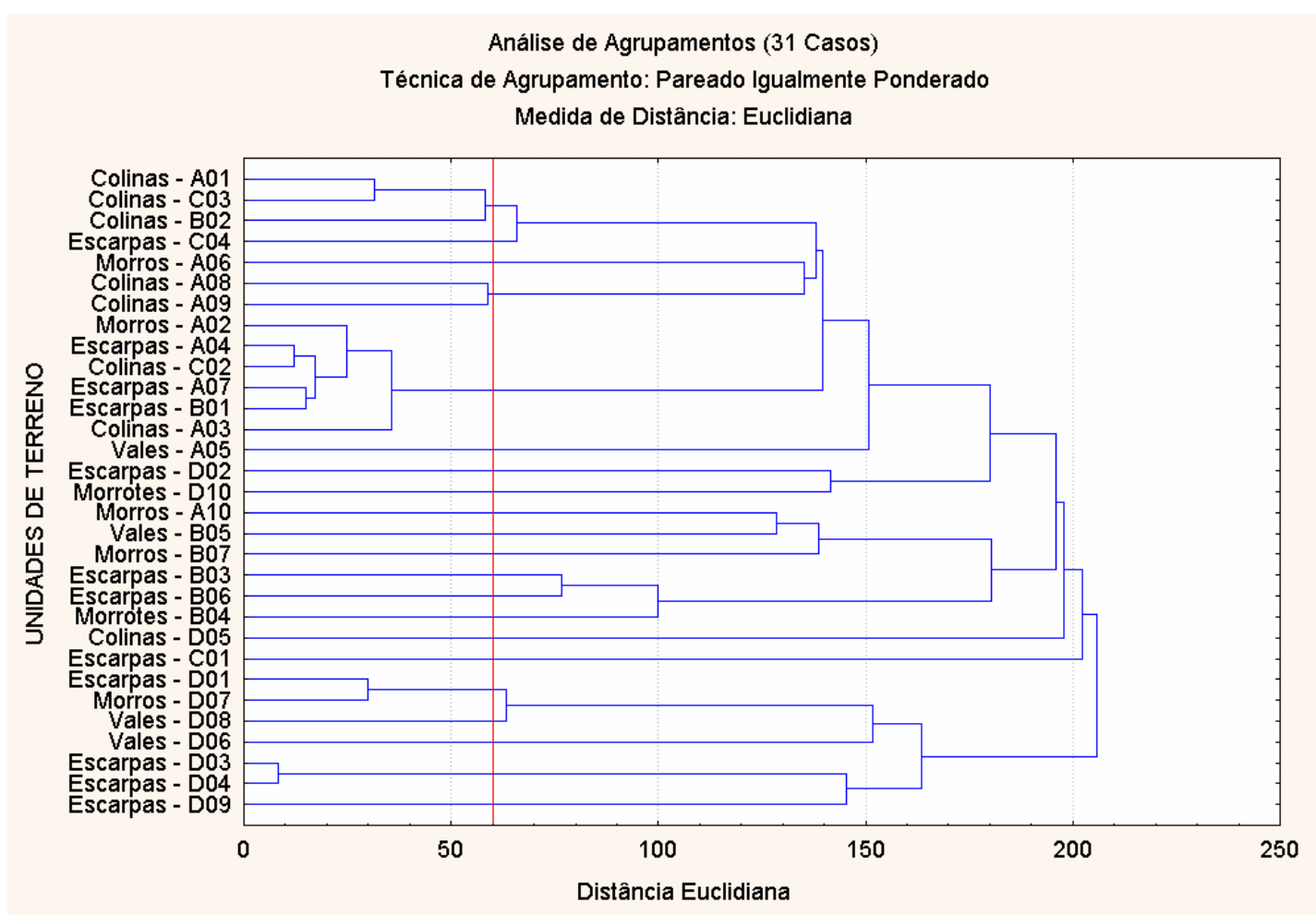

FIGURA 6.2 - Análise de agrupamentos (modo Q) realizada a partir das superfícies ocupadas em cada unidade de terreno pelas classes/unidades de declividades, de potencial agrícola, de substrato rochoso e de materiais inconsolidados.

A partir do valor igual a 60 são estabelecidos 21 agrupamentos (Tabela 6.1) onde os vales não formam agrupamentos com outras feições de relevo, entretanto esses ocorrem entre outras feições de relevo nas seguintes unidades geoambientais:

$\checkmark 01$ entre três tipos de colinas (A01, C03 e B02);

$\checkmark \quad 04$ entre dois tipos de colinas (A08 e A09);

$\checkmark 05$ entre três tipos de escarpas(A04, A07 e B01), dois de colinas (C02 e A03) e um de morro (A02);

17 entre um tipo de escarpa (D01) e outro de morro (D07);

20 entre dois tipos de escarpas (D03 e D04). 
TABELA 6.1 - Unidades geoambientais e sua(s) unidade(s) de terreno correspondente(s).

\begin{tabular}{|c|c|}
\hline Unidade Geoambiental & Unidade(s) de Terreno (s) Correspondente (s) \\
\hline 01 & A01, C03 e B02 \\
\hline 02 & C04 \\
\hline 03 & A06 \\
\hline 04 & A08 e A09 \\
\hline 05 & A02, A04, C02, A07, B01 e A03 \\
\hline 06 & D02 \\
\hline 07 & D10 \\
\hline 08 & A10 \\
\hline 09 & B05 \\
\hline 10 & B07 \\
\hline 11 & B03 \\
\hline 12 & B06 \\
\hline 13 & B04 \\
\hline 14 & D05 \\
\hline 15 & C01 \\
\hline 16 & D01 e D07 \\
\hline 17 & D08 \\
\hline 18 & D06 \\
\hline 19 & D03 e D04 \\
\hline 20 & D09 \\
\hline 21 & \\
\hline & \\
\hline & \\
\hline
\end{tabular}

Com relação a homogeneidade das unidades de terreno agrupadas a partir dos atributos do meio físico, esta pode ser facilmente percebida pela análise da figura 6.3. Nela, o dendograma apresentado é similar ao anterior (Figura 6.2) se diferenciando somente na distância euclidiana máxima atingida na formação dos dois principais agrupamentos que passa de 205,64 para $100 \%$. No dendograma da figura 6.3, os 21 agrupamentos obtidos com uma distância euclidiana de 60 no dendograma anterior (Figura 6.2), agora correspondem a um valor igual a $29 \%$, ou seja, as unidades de terreno agrupadas apresentam sempre mais de $71 \%$ de similaridade, podendo atingir o valor de $96 \%$ (agrupamento entre as unidades D03 e D04 na composição da Unidade Geoambiental 20). 


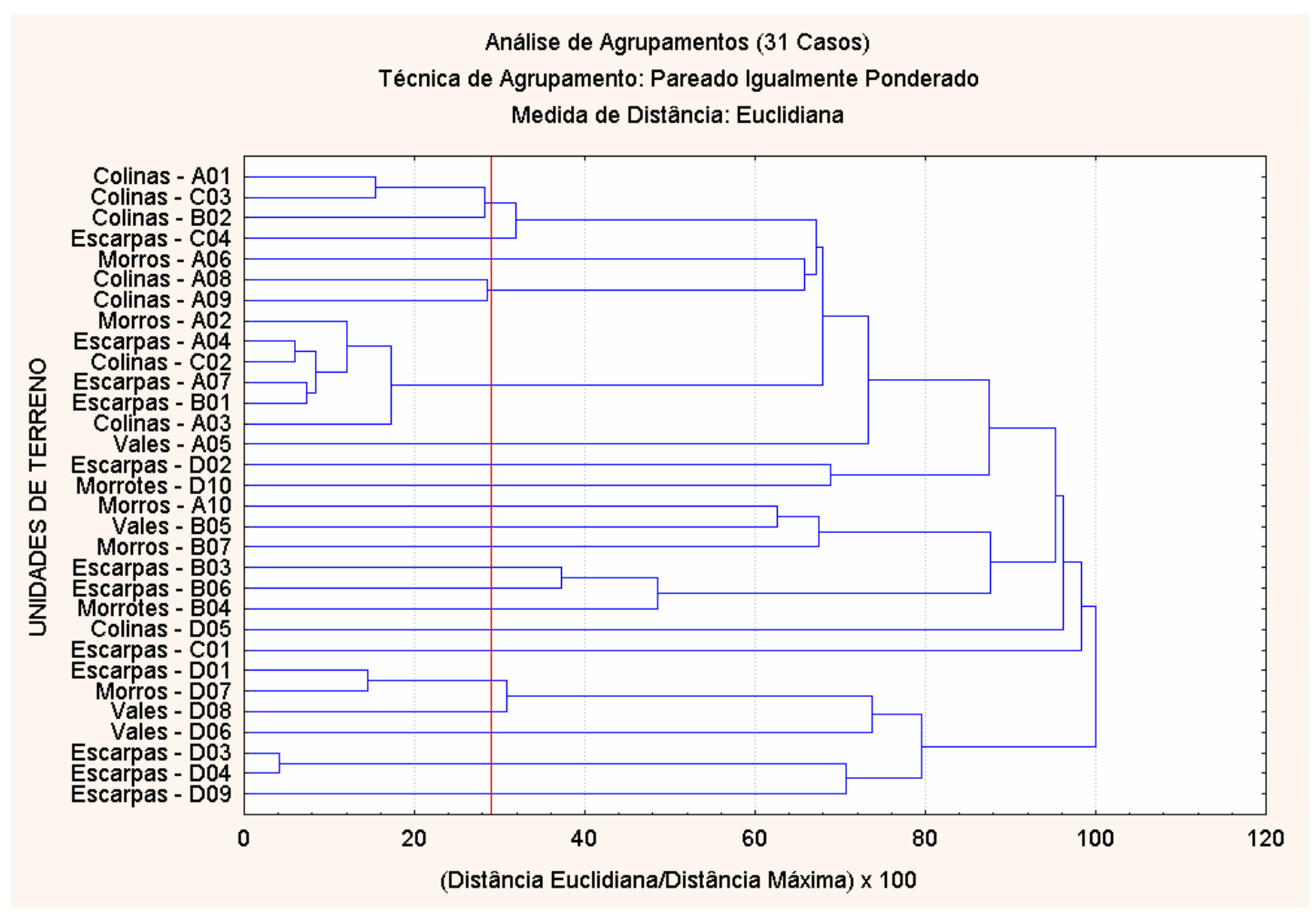

FIGURA 6.3 - Análise de agrupamentos (modo Q) realizada a partir das superfícies ocupadas em cada unidade de terreno pelas classes/unidades de declividades, de potencial agrícola, de substrato rochoso e de materiais inconsolidados onde a distância euclidiana máxima atingida é igual a $100 \%$.

Sobre os cinco agrupamentos realizados, cuja as unidades geoambientais possuem mais de uma unidade de terreno, pode-se afirmar:

$\checkmark$ As Unidades de Terreno A01, C03 e B02, que compõem a Unidade Geoambiental 01, correspondem a colinas que apresentam materiais inconsolidados da classe textural $\mathrm{V}$, de origem residual desenvolvidos sobre migmatitos graníticos e estromatíticos. 
$\checkmark$ A Unidade Geoambiental 04 é formada por colinas das Unidades de Terreno A08 e A09. Estas apresentam pelo menos 2/3 de seus substratos rochosos compostos por migmatitos graníticos e estromatíticos. Do mesmo modo, até $60 \%$ de seus materiais inconsolidados são coincidentes. São materiais de natureza residual onde são encontradas as classes texturais IV, V e VI. Por outro lado, A08 e A09 exibem menores variabilidades quando analisadas suas classes de declividades e de potencial agrícola.

As Unidades de Terreno A02, A04, C02, A07, B01 e A03 que compõem a Unidade Geoambiental 05 apresentam como substrato rochoso migmatitos graníticos e estromatíticos, onde se desenvolvem materiais inconsolidados residuais pertencentes ao grupo textural III. As classes de declividades tem pequena variação, assim como as de potencial agrícola, estas estabelecendo para as unidades de terreno de 50 a $75 \%$ de potencial moderado e ausência de setores com potencial severo.

$\checkmark$ A Unidade Geoambiental 17 é formada por unidades de terrenos que apresentam feições de relevo do tipo escarpas (D01) e de morros (D07) cujo o substrato rochoso é composto por fonólitos e tinguaítos. Seus materiais inconsolidados são de natureza residual pertencentes ao grupo textural VII.

$\checkmark$ A Unidade Geoambiental 20 é formada pelas unidades de terreno que apresentam as maiores similaridades entre as 41 variáveis analisadas. As unidades D3 e D4 são constituídas por escarpas cujo substrato rochoso é composto por fonólitos e tinguaítos. Seus materiais inconsolidados são de natureza residual pertencente ao grupo textural VIII. Os valores apresentados pelas unidades de terreno nos intervalos de declividades e de potencial agrícola são muito próximos (ver ANEXO IX). Nas unidades D3 e D4 predominam em mais da metade de suas superfícies a classe de adequabilidade severa de potencial agrícola.

Por fim, percebe-se que as unidades geoambientais não formam qualquer tipo agrupamento considerando as mesmas condições de contorno estabelecidas para as unidades de terreno, conforme mostra as Figuras 6.4 e 6.5. 


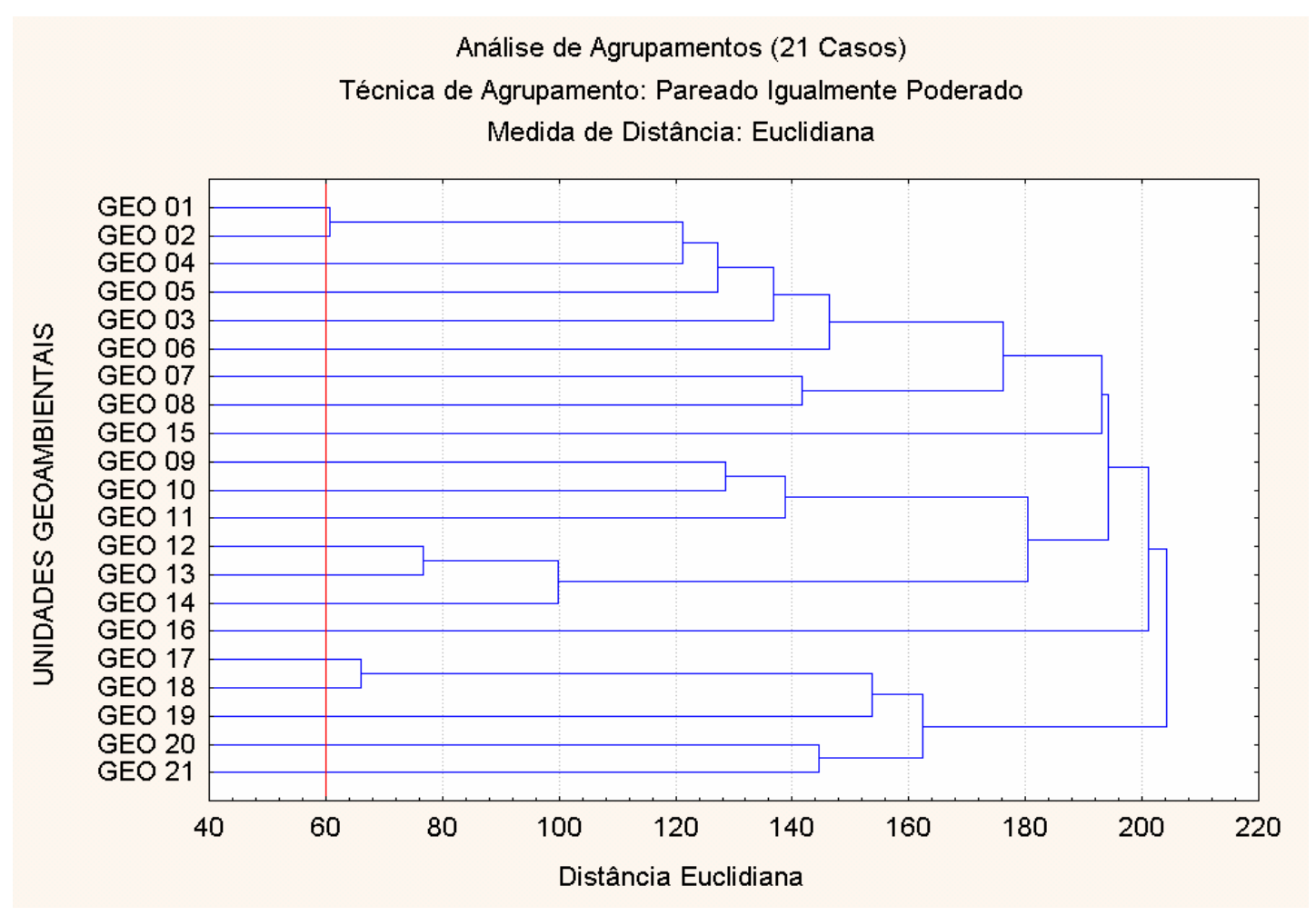

FIGURA 6.4 - Análise de agrupamentos (modo Q) realizada a partir das superfícies ocupadas em cada unidade geoambiental pelas classes/unidades de declividades, de potencial agrícola, de substrato rochoso e de materiais inconsolidados.

Tal avaliação é muito importante pois verifica se o grau de heterogeneidade apontado para as unidades geoambientais durante o agrupamento das unidades de terreno é mantido. Desse modo, é possível saber se a reclassificação é apropriada, pois se essa não fosse, mostraria agrupamentos com uma distância euclidiana menor que a adotada, o que significa uma maior homogeneidade, não verificada no agrupamento das unidades de terreno, portanto tal reclassificação seria considerada inconsistente.

Analisando o dendograma da Figura 6.4 nota-se que a distância euclidiana igual a 60 não forma agrupamentos entre as unidade geoambientais. Além disso, verifica-se que a distância euclidiana máxima atingida é praticamente a mesma observada na Figura 6.2 (referente ao agrupamento das unidades de terreno) que passa de 205,64 para 204,27. 


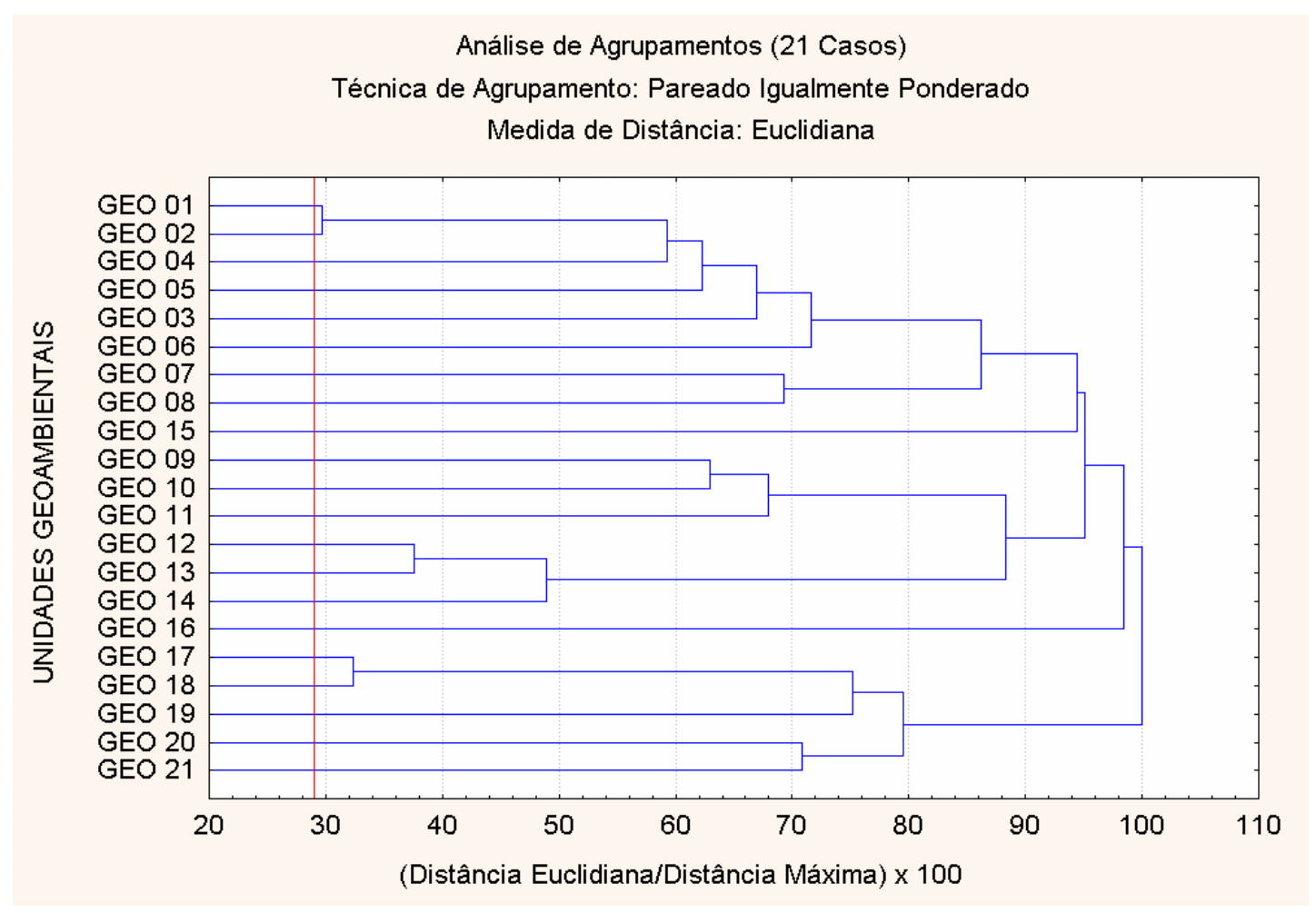

FIGURA 6.5 - Análise de agrupamentos (modo Q) realizada a partir das superfícies ocupadas em cada unidade geoambiental pelas classes/unidades de declividades, de potencial agrícola, de substrato rochoso e de materiais inconsolidados onde a distância euclidiana máxima atingida é igual a $100 \%$.

Do mesmo modo na Figura 6.5, onde a distância euclidiana máxima atingida é igual a $100 \%$, não se formam agrupamentos entre as unidades geoambientais considerando a distância igual a $29 \%$.

Por outro lado, observa-se que a distância que agrupa as Unidades Geoambientais 01 e 02 diminui quando passa de 65,70, no dendograma da Figura 6.4, para 60,62 na Figura 6.5, entretanto a distância que agrupa as unidades 17 e 18 aumenta de um dendograma para o outro passando de 63,44 para 66,11. 


\subsection{Análise das Aptidões e das Situações de Uso e Ocupação do Meio Físico nas Unidades Geoambientais}

\subsubsection{Aptidões do Meio Físico nas Unidades Geoambientais}

A análise das aptidões do meio físico é fundamental para uma utilização adequada das unidades geoambientais. Por meio dessa análise é possível estabelecer para as unidades, por exemplo, em quais destas predomina setores com potenciais considerados favoráveis frente aos de caráter restritivos a partir das mais diferentes formas de solicitação de uso e ocupação do meio físico.

Nessa pesquisa foi somente analisada a aptidão agrícola da área estudada pois foi a única carta dessa natureza produzida, contudo o exame de diferentes classes de adequabilidades do meio físico poderiam ser obtidas, assim como foram para a carta de potencial agrícola proposta por Zuquette (1993), também poderiam para as outras cartas de aptidão sugeridas pelo autor, são elas: carta de potencial a corrossividade, carta para fundações, carta de condições de escavabilidade, carta para barragens rurais, carta para estradas e carta de disposição de resíduos (aterros sanitários).

A análise do potencial agrícola realizada foi por meio de agrupamentos utilizando o STATISTICA® 5.5 através da técnica de agrupamento pareado igualmente ponderado empregando a medida de distância euclidiana.

Os dendogramas produzidos por essa análise apresentam distâncias euclidianas máximas de formação de agrupamentos de 61,14 e $100 \%$ respectivamente, conforme mostram as Figuras 6.6 e 6.7. O exame desses dendogramas apontam para a existência de quatro agrupamentos com características bem distintas com distâncias euclidianas assumidas de 29 e $47 \%$ respectivamente.

De acordo com análise de agrupamentos realizada, pode-se afirmar:

As unidades geoambientais 01 e 06 possuem aproximadamente $25 \%$ de suas superfícies pertencentes a classe proibida de potencial agrícola e em torno de 40 a $50 \%$ de composição moderada.

$\checkmark$ Entre 50 e $75 \%$ aproximadamente das superfícies das unidades $02,05,14,11$, 12, 10, 04, 09, 17, 03, 16 e 19 possui adequabilidade agrícola moderada. 


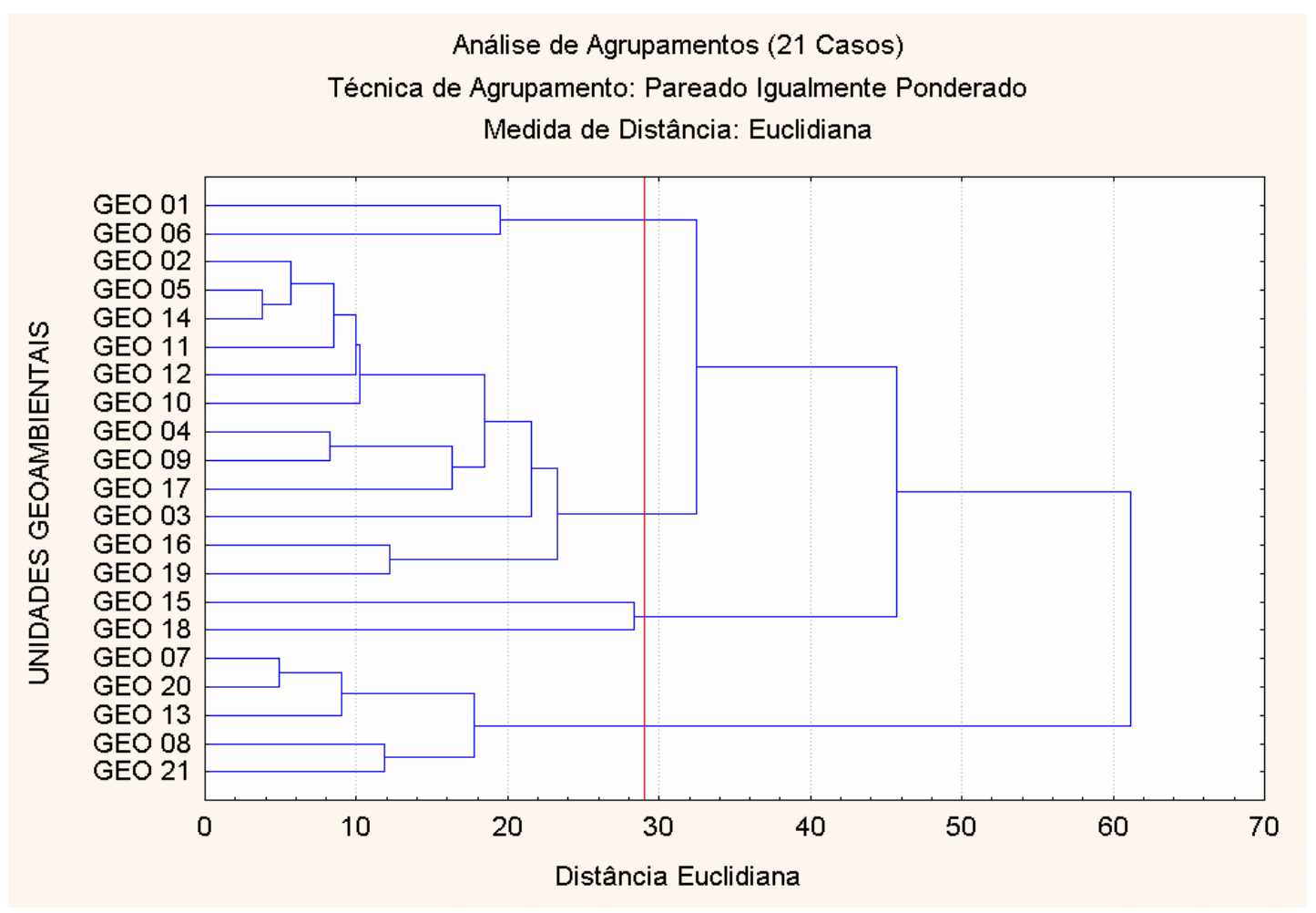

FIGURA 6.6 - Análise de agrupamentos (modo Q) realizada a partir das superfícies ocupadas pelas classes de potencial agrícola em cada unidade geoambiental.

As unidades 15 e 18 são as que apresentam as melhores condições de aptidão agrícola, pois possuem de modo aproximado entre 1/3 e 2/3 de suas superfícies com potencial favorável, enquanto que entre 30 e $50 \%$ são tidas como moderadas.

As unidades 07, 20, 13, 08 e 21, por outro lado, expressam as piores condições de aptidão agrícola com aproximadamente metade de suas superfícies pertencentes a classe severa além de apresentar entre 8,94 e 24,29\% de classe proibida. 


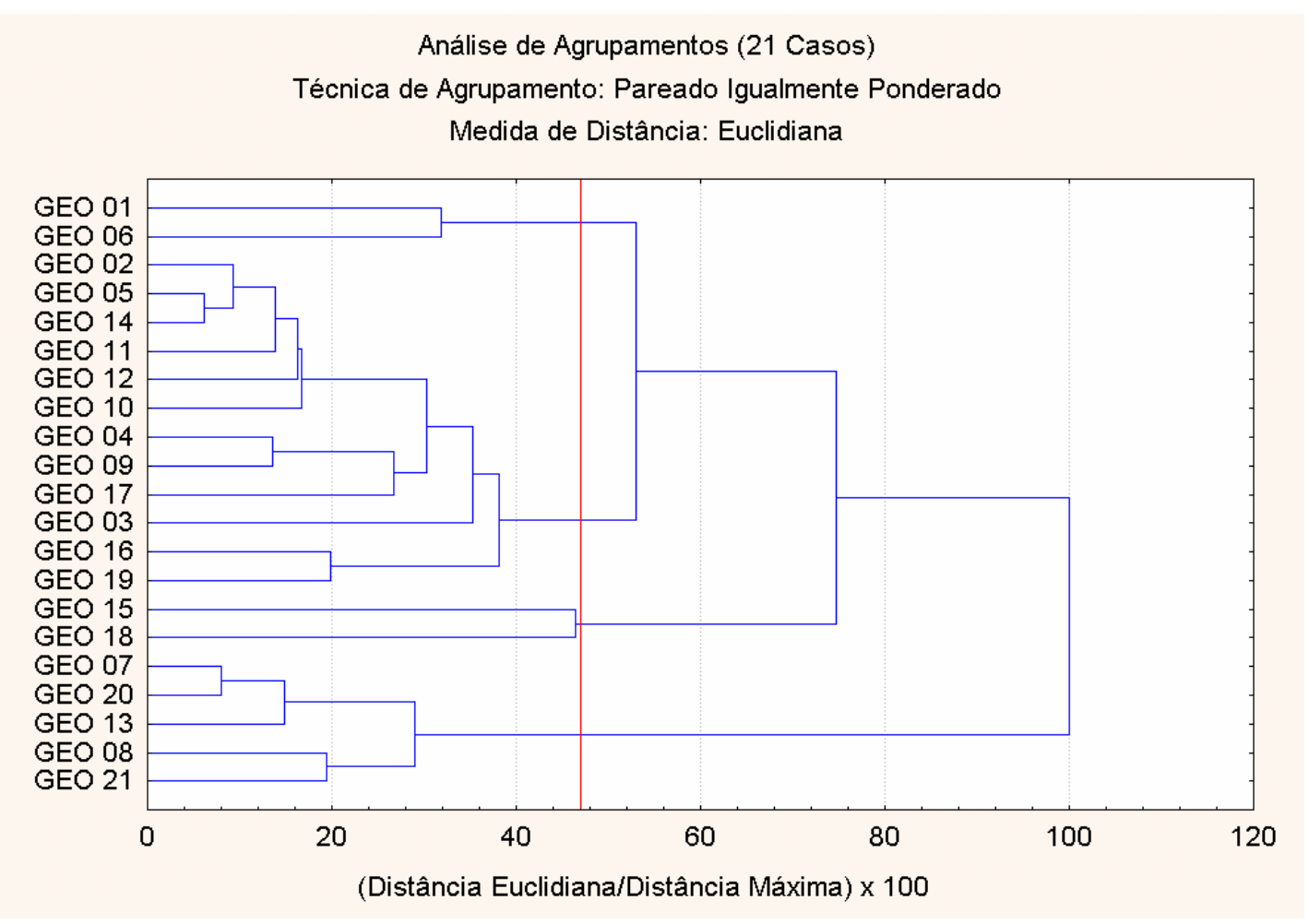

FIGURA 6.7 - Análise de agrupamentos (modo Q) realizada a partir das superfícies ocupadas em cada unidade geoambiental pelas classes de potencial agrícola onde a distância euclidiana máxima atingida é igual a 100 $\%$.

\subsubsection{Situação do Uso e Ocupação do Meio Físico nas Unidades Geoambientais}

A distribuição das formas de uso e ocupação do meio físico sobre as unidades geoambientais foram avaliadas nessa pesquisa tanto de modo mais geral quanto mais específico.

Para fazer a avaliação genérica foram calculadas por tabulação cruzada (ver o procedimento na sessão 6.2) o percentual em área das unidades de uso e ocupação, excetuando as áreas ocupadas pelas águas represadas, compreendidas nas classes das cartas de declividade e potencial agrícola e nas unidades dos mapas de substrato rochoso e materiais inconsolidados. 
Além disso, buscourse estabelecer o percentual que cada classe ou unidade apresenta de sua superfície ocupada pelos diferentes tipos de uso e ocupação (excetuando a classe de água represada). Os resultados encontram-se nas Tabelas 6.2, $6.3,6.4,6.5$ e 6.6 .

O exame dessa tabelas apontam:

* Quanto as áreas ocupadas por pasto:

$>$ Desenvolvem-se praticamente por todas as classes de declividades principalmente nas mais baixas que vão de 0 a $20 \%$.

Em relação às rochas do Maciço Alcalino de Poços de Caldas, predominam em mais da metade nos nefelina sienitos enquanto no Complexo Varginha nos migmatitos graníticos e nos estromatíticos.

São maioria nos materiais inconsolidados (mais de $50 \%$ ):

- Retrabalhados pertencentes ao grupo textural I de origem aluvionar apresentando espessuras variáveis.

- Residuais de fonólitos e tinguaítos pertecentes ao grupo textural IV apresentando espessuras superiores a 3,0 m.

- Residuais de nefelina sienitos pertecentes ao grupo textural III com espessuras variando entre 0,5 e $1,5 \mathrm{~m}$.

- Residuais de migmatitos graníticos e estromatíticos pertencentes ao grupo textural II com espessuras variando entre 1,5 e 3,0 m.

- Residuais de migmatitos graníticos e estromatíticos pertencentes ao grupo textural III com espessuras variando entre 1,5 e 3,0 m.

- Residuais de migmatitos graníticos e estromatíticos pertencentes ao grupo textural III apresentando espessuras superiores a 3,0 m.

- Residuais de migmatitos graníticos e estromatíticos pertencentes ao grupo textural VII com espessuras variando entre 1,5 e 3,0 m.

- Residuais de migmatitos graníticos e estromatíticos pertencentes aos grupos textural IV, V e VI apresentando espessuras variáveis.

Predominam em mais da metade das classes de potencial agrícola favorável, moderada e restritiva. 
TABELA 6.2 - Relação entre os setores destinados a pecuária bovina extensiva e as diversas classes/unidades presentes nas cartas de declividades e potencial agrícola e nos mapas de substrato rochoso e materiais inconsolidados.

\begin{tabular}{|c|c|c|c|c|}
\hline & $\begin{array}{l}\text { Número } \\
\text { de Pixels }\end{array}$ & \begin{tabular}{|l|} 
Número de \\
$\quad$ Pixels \\
Coincidentes \\
com o Pasto \\
\end{tabular} & \begin{tabular}{|c|} 
Percentual da \\
Superfície de Pasto \\
que as classes/unidades \\
Ocorrem \\
\end{tabular} & $\begin{array}{c}\text { Percentual de } \\
\text { Pasto que as } \\
\text { classes/unidades } \\
\text { Apresentam } \\
\end{array}$ \\
\hline PASTO & 261082 & & - & - \\
\hline Declivi Men que $2 \%$ & 10373 & 5491 & 2,10 & 52,94 \\
\hline Declivi de 2 a $5 \%$ & 47541 & 26376 & 10,10 & 55,48 \\
\hline Declivi de 5 a $10 \%$ & 86075 & 45052 & 17,26 & 52,34 \\
\hline Declivi de 10 a $15 \%$ & 79272 & 40051 & 15,34 & $\mathbf{5 0 , 5 2}$ \\
\hline Declivi de 15 a $20 \%$ & 75510 & 37800 & 14,48 & 50,06 \\
\hline Declivi de 20 a $25 \%$ & 65662 & 32356 & 12,39 & 49,28 \\
\hline Declivi de 25 a $30 \%$ & 45954 & 21891 & 8,38 & 47,64 \\
\hline Declivi de 30 a $47 \%$ & 110906 & 43343 & 16,60 & 39,08 \\
\hline Declivi de Mai 47 \% & 15469 & 3913 & 1,50 & 25,30 \\
\hline Fonólitos e Tinguaítos & 52643 & 14776 & 5,66 & 28,07 \\
\hline Nefelina Sienitos & 57354 & 29377 & 11,25 & 51,22 \\
\hline Charnockitos & 86416 & 37691 & 14,44 & 43,62 \\
\hline Granulitos Quart-feldsp & 74057 & 36781 & 14,09 & 49,67 \\
\hline Migmatitos Graní e Estrom & 260483 & 135054 & 51,73 & 51,85 \\
\hline Migmatitos Oftalmíticos & 5808 & 2591 & 0,99 & 44,61 \\
\hline Materiais Inconsolidados 01 & 1240 & 1022 & 0,39 & 82,42 \\
\hline Materiais Inconsolidados 02 & 2581 & 409 & 0,16 & 15,85 \\
\hline Materiais Inconsolidados 03 & 45191 & 17644 & 6,76 & 39,04 \\
\hline Materiais Inconsolidados 04 & 3598 & 1070 & 0,41 & 29,74 \\
\hline Materiais Inconsolidados 05 & 3109 & 2084 & 0,80 & 67,03 \\
\hline Materiais Inconsolidados 06 & 17024 & 6923 & 2,65 & 40,67 \\
\hline Materiais Inconsolidados 07 & 28932 & 4732 & 1,81 & 16,36 \\
\hline Materiais Inconsolidados 08 & 49956 & 27313 & 10,46 & 54,67 \\
\hline Materiais Inconsolidados 09 & 39643 & 17437 & 6,68 & 43,99 \\
\hline Materiais Inconsolidados 10 & 42901 & 18642 & 7,14 & 43,45 \\
\hline Materiais Inconsolidados 11 & 3873 & 1622 & 0,62 & 41,88 \\
\hline Materiais Inconsolidados 12 & 402 & 100 & 0,04 & 24,88 \\
\hline Materiais Inconsolidados 13 & 63571 & 31222 & 11,96 & 49,11 \\
\hline Materiais Inconsolidados 14 & 2227 & 549 & 0,21 & 24,65 \\
\hline Materiais Inconsolidados 15 & 20470 & 10303 & 3,95 & 50,33 \\
\hline Materiais Inconsolidados 16 & 38528 & 21709 & 8,32 & 56,35 \\
\hline Materiais Inconsolidados 17 & 6122 & 3005 & 1,15 & 49,09 \\
\hline Materiais Inconsolidados 18 & 17631 & 8030 & 3,08 & 45,54 \\
\hline Materiais Inconsolidados 19 & 5972 & 3646 & 1,40 & 61,05 \\
\hline Materiais Inconsolidados 20 & 137974 & 76215 & 29,19 & 55,24 \\
\hline Materiais Inconsolidados 21 & 5810 & 2593 & 0,99 & 44,63 \\
\hline Pot Agrícola Favorável & 95286 & 48960 & 18,75 & 51,38 \\
\hline Pot Agrícola Moderado & 289646 & 142155 & 54,45 & 49,08 \\
\hline Pot Agrícola Seve ro & 52747 & 16667 & 6,38 & 31,60 \\
\hline Pot Agrícola Restrito & 2382 & 1534 & 0,59 & 64,40 \\
\hline Uso Agrícola Proibido & 96701 & 46956 & 17,99 & 48,56 \\
\hline
\end{tabular}


TABELA 6.3 - Relação entre os setores destinados a monocultura cafeeira e as diversas classes/unidades presentes nas cartas de declividades e potencial agrícola e nos mapas de substrato rochoso e materiais inconsolidados.

\begin{tabular}{|c|c|c|c|c|}
\hline & $\begin{array}{l}\text { Número } \\
\text { de Pixels }\end{array}$ & \begin{tabular}{|l} 
Número de \\
Pixels \\
Coincidentes \\
com o Café
\end{tabular} & $\begin{array}{c}\text { Percentual da } \\
\text { Superfície de Café que } \\
\text { as classes/unidades } \\
\text { Ocorrem }\end{array}$ & $\begin{array}{c}\text { Percentual de } \\
\text { Café que as } \\
\text { classes/unidades } \\
\text { Apresentam }\end{array}$ \\
\hline CAFÉ & 130348 & - & - & - \\
\hline Declivi Men que $2 \%$ & 10373 & 1392 & 1,07 & 13,42 \\
\hline Declivi de 2 a $5 \%$ & 47541 & 8555 & 6,56 & 17,99 \\
\hline Declivi de 5 a $10 \%$ & 86075 & 17583 & 13,49 & 20,43 \\
\hline Declivi de 10 a $15 \%$ & 79272 & 18375 & 14,10 & 23,18 \\
\hline Declivi de 15 a $20 \%$ & 75510 & 17500 & 13,43 & 23,18 \\
\hline Declivi de 20 a $25 \%$ & 65662 & 15508 & 11,90 & 23,62 \\
\hline Declivi de 25 a $30 \%$ & 45954 & 10857 & 8,33 & 23,63 \\
\hline Declivi de 30 a $47 \%$ & 110906 & 33091 & 25,39 & 29,84 \\
\hline Declivi de Mai $47 \%$ & 15469 & 6573 & 5,04 & 42,49 \\
\hline Fonólitos e Tinguaítos & 52643 & 5408 & 4,15 & 10,27 \\
\hline Nefelina Sienitos & 57354 & 4213 & 3,23 & 7,35 \\
\hline Charnockitos & 86416 & 28727 & 22,04 & 33,24 \\
\hline Granulitos Quart-feldsp & 74057 & 21920 & 16,82 & 29,60 \\
\hline Migmatitos Graní e Estrom & 260483 & 67507 & 51,79 & 25,92 \\
\hline Migmatitos Oftalmíticos & 5808 & 1660 & 1,27 & 28,58 \\
\hline Materiais Inconsolidados 01 & 1240 & 87 & 0,07 & 7,02 \\
\hline Materiais Inconsolidados 02 & 2581 & 0 & 0,00 & 0,00 \\
\hline Materiais Inconsolidados 03 & 45191 & 19103 & 14,66 & 42,27 \\
\hline Materiais Inconsolidados 04 & 3598 & 267 & 0,20 & 7,42 \\
\hline Materiais Inconsolidados 05 & 3109 & 20 & 0,02 & 0,64 \\
\hline Materiais Inconsolidados 06 & 17024 & 221 & 0,17 & 1,30 \\
\hline Materiais Inconsolidados 07 & 28932 & 4898 & 3,76 & 16,93 \\
\hline Materiais Inconsolidados 08 & 49956 & 2193 & 1,68 & 4,39 \\
\hline Materiais Inconsolidados 09 & 39643 & 12783 & 9,81 & 32,25 \\
\hline Materiais Inconsolidados 10 & 42901 & 14388 & 11,04 & 33,54 \\
\hline Materiais Inconsolidados 11 & 3873 & 1562 & 1,20 & 40,33 \\
\hline Materiais Inconsolidados 12 & 402 & 134 & 0,10 & 33,33 \\
\hline Materiais Inconsolidados 13 & 63571 & 19502 & 14,96 & 30,68 \\
\hline Materiais Inconsolidados 14 & 2227 & 1127 & 0,86 & 50,61 \\
\hline Materiais Inconsolidados 15 & 20470 & 5455 & 4,18 & 26,65 \\
\hline Materiais Inconsolidados 16 & 38528 & 8266 & 6,34 & 21,45 \\
\hline Materiais Inconsolidados 17 & 6122 & 961 & 0,74 & 15,70 \\
\hline Materiais Inconsolidados 18 & 17631 & 4657 & 3,57 & 26,41 \\
\hline Materiais Inconsolidados 19 & 5972 & 1064 & 0,82 & 17,82 \\
\hline Materiais Inconsolidados 20 & 137974 & 31082 & 23,85 & 22,53 \\
\hline Materiais Inconsolidados 21 & 5810 & 1660 & 1,27 & 28,57 \\
\hline Pot Agrícola Favorável & 95286 & 20751 & 15,92 & 21,78 \\
\hline Pot Agrícola Moderado & 289646 & 68293 & 52,39 & 23,58 \\
\hline Pot Agrícola Severo & 52747 & 17399 & 13,35 & 32,99 \\
\hline Pot Agrícola Restrito & 2382 & 307 & 0,24 & 12,89 \\
\hline Uso Agrícola Proibido & 96701 & 22684 & 17,40 & 23,46 \\
\hline
\end{tabular}


TABELA 6.4 - Relação entre os setores de floresta nativa e as diversas classes/unidades presentes nas cartas de declividades e potencial agrícola e nos mapas de substrato rochoso e materiais inconsolidados.

\begin{tabular}{|c|c|c|c|c|}
\hline & $\begin{array}{l}\text { Número } \\
\text { de Pixels }\end{array}$ & \begin{tabular}{|c|}
$\begin{array}{c}\text { Número de } \\
\text { Pixels } \\
\text { Coincidentes } \\
\text { com a Mata } \\
\text { Nativa }\end{array}$ \\
\end{tabular} & $\begin{array}{c}\text { Percentual da } \\
\text { Superfície de Mata } \\
\text { Nativa que as } \\
\text { classes/unidades } \\
\text { Ocorrem }\end{array}$ & $\begin{array}{c}\text { Percentual de } \\
\text { Mata Nativa que } \\
\text { as } \\
\text { classes/unidades } \\
\text { Apresentam }\end{array}$ \\
\hline MATA NATIVA & 103720 & \begin{tabular}{l|l}
- & \\
\end{tabular} & - & - \\
\hline Declivi Men que $2 \%$ & 10373 & 1237 & 1,19 & 11,93 \\
\hline Declivi de 2 a $5 \%$ & 47541 & 6245 & 6,02 & 13,14 \\
\hline Declivi de 5 a $10 \%$ & 86075 & 12845 & 12,38 & 14,92 \\
\hline Declivi de 10 a $15 \%$ & 79272 & 12235 & 11,80 & 15,43 \\
\hline Declivi de 15 a $20 \%$ & 75510 & 13294 & 12,82 & 17,61 \\
\hline Declivi de 20 a $25 \%$ & 65662 & 12567 & 12,12 & 19,14 \\
\hline Declivi de 25 a $30 \%$ & 45954 & 10044 & 9,68 & 21,86 \\
\hline Declivi de 30 a $47 \%$ & 110906 & 28067 & 27,06 & 25,31 \\
\hline Declivi de Mai 47 \% & 15469 & 4504 & 4,34 & 29,12 \\
\hline Fonólitos e Tinguaítos & 52643 & 20082 & 19,36 & 38,15 \\
\hline Nefelina Sienitos & 57354 & 10491 & 10,11 & 18,29 \\
\hline Charnockitos & 86416 & 15628 & 15,07 & 18,08 \\
\hline Granulitos Quart-feldsp & 74057 & 11538 & 11,12 & 15,58 \\
\hline Migmatitos Graní e Estrom & 260483 & 41898 & 40,40 & 16,08 \\
\hline Migmatitos Oftalmíticos & 5808 & 1402 & 1,35 & 24,14 \\
\hline Materiais Inconsolidados 01 & 1240 & 119 & 0,11 & 9,60 \\
\hline Materiais Inconsolidados 02 & 2581 & 53 & 0,05 & 2,05 \\
\hline Materiais Inconsolidados 03 & 45191 & 6361 & 6,13 & 14,08 \\
\hline Materiais Inconsolidados 04 & 3598 & 2198 & 2,12 & 61,09 \\
\hline Materiais Inconsolidados 05 & 3109 & 654 & 0,63 & 21,04 \\
\hline Materiais Inconsolidados 06 & 17024 & 1414 & 1,36 & 8,31 \\
\hline Materiais Inconsolidados 07 & 28932 & 15805 & 15,24 & 54,63 \\
\hline Materiais Inconsolidados 08 & 49956 & 9531 & 9,19 & 19,08 \\
\hline Materiais Inconsolidados 09 & 39643 & 7238 & 6,98 & 18,26 \\
\hline Materiais Inconsolidados 10 & 42901 & 8013 & 7,73 & 18,68 \\
\hline Materiais Inconsolidados 11 & 3873 & 359 & 0,35 & 9,27 \\
\hline Materiais Inconsolidados 12 & 402 & 168 & 0,16 & 41,79 \\
\hline Materiais Inconsolidados 13 & 63571 & 9772 & 9,42 & 15,37 \\
\hline Materiais Inconsolidados 14 & 2227 & 362 & 0,35 & 16,26 \\
\hline Materiais Inconsolidados 15 & 20470 & 2470 & 2,38 & 12,07 \\
\hline Materiais Inconsolidados 16 & 38528 & 5806 & 5,60 & 15,07 \\
\hline Materiais Inconsolidados 17 & 6122 & 1562 & 1,51 & 25,51 \\
\hline Materiais Inconsolidados 18 & 17631 & 3594 & 3,47 & 20,38 \\
\hline Materiais Inconsolidados 19 & 5972 & 904 & 0,87 & 15,14 \\
\hline Materiais Inconsolidados 20 & 137974 & 23254 & 22,42 & 16,85 \\
\hline Materiais Inconsolidados 21 & 5810 & 1402 & 1,35 & 24,13 \\
\hline Pot Agrícola Favorável & 95286 & 14018 & 13,52 & 14,71 \\
\hline Pot Agrícola Moderado & 289646 & 55105 & 53,13 & 19,02 \\
\hline Pot Agrícola Severo & 52747 & 15400 & 14,85 & 29,20 \\
\hline Pot Agrícola Restrito & 2382 & 440 & 0,42 & 18,47 \\
\hline Uso Agrícola Proi bido & 96701 & 16076 & 15,50 & 16,62 \\
\hline
\end{tabular}


TABELA 6.5 - Relação entre os setores sem cobertura vegetal e as diversas classes/unidades presentes nas cartas de declividades e potencial agrícola e nos mapas de substrato rochoso e materiais inconsolidados.

\begin{tabular}{|c|c|c|c|c|}
\hline & $\begin{array}{l}\text { Número } \\
\text { de Pixels }\end{array}$ & \begin{tabular}{|l|} 
Número de \\
$\quad$ Pixels \\
Coincidentes \\
com o Solo \\
Exposto \\
\end{tabular} & $\begin{array}{c}\text { Percentual da } \\
\text { Superfície de Solo } \\
\text { Exposto que as } \\
\text { classes/unidades } \\
\text { Ocorrem } \\
\end{array}$ & $\begin{array}{c}\text { Percentual de } \\
\text { Solo Exposto que } \\
\text { as } \\
\text { classes/unidades } \\
\text { Apresentam } \\
\end{array}$ \\
\hline SOLO EXPOSTO & 16267 & - & - & - \\
\hline Declivi Men que $2 \%$ & 10373 & 202 & 1,24 & 1,95 \\
\hline Declivi de 2 a $5 \%$ & 47541 & 1294 & 7,95 & 2,72 \\
\hline Declivi de 5 a $10 \%$ & 86075 & 2524 & 15,52 & 2,93 \\
\hline Declivi de 10 a $15 \%$ & 79272 & 2340 & 14,38 & 2,95 \\
\hline Declivi de 15 a $20 \%$ & 75510 & 2455 & 15,09 & 3,25 \\
\hline Declivi de 20 a $25 \%$ & 65662 & 2394 & 14,72 & 3,65 \\
\hline Declivi de 25 a $30 \%$ & 45954 & 1463 & 8,99 & 3,18 \\
\hline Declivi de 30 a $47 \%$ & 110906 & 3076 & 18,91 & 2,77 \\
\hline Declivi de Mai $47 \%$ & 15469 & 346 & 2,13 & 2,24 \\
\hline Fonólitos e Tinguaítos & 52643 & 162 & 1,00 & 0,31 \\
\hline Nefelina Sienitos & 57354 & 626 & 3,85 & 1,09 \\
\hline Charnockitos & 86416 & 2906 & 17,86 & 3,36 \\
\hline Granulitos Quart-feldsp & 74057 & 2382 & 14,64 & 3,22 \\
\hline Migmatitos Graní e Estrom & 260483 & 9888 & 60,79 & 3,80 \\
\hline Migmatitos Oftalmíticos & 5808 & 130 & 0,80 & 2,24 \\
\hline Materiais Inconsolidados 01 & 1240 & 12 & 0,07 & 0,97 \\
\hline Materiais Inconsolidados 02 & 2581 & 0 & 0,00 & 0,00 \\
\hline Materiais Inconsolidados 03 & 45191 & 1361 & 8,37 & 3,01 \\
\hline Materiais Inconsolidados 04 & 3598 & 0 & 0,00 & 0,00 \\
\hline Materiais Inconsolidados 05 & 3109 & 0 & 0,00 & 0,00 \\
\hline Materiais Inconsolidados 06 & 17024 & 10 & 0,06 & 0,06 \\
\hline Materiais Inconsolidados 07 & 28932 & 154 & 0,95 & 0,53 \\
\hline Materiais Inconsolidados 08 & 49956 & 554 & 3,41 & 1,11 \\
\hline Materiais Inconsolidados 09 & 39643 & 1240 & 7,62 & 3,13 \\
\hline Materiais Inconsolidados 10 & 42901 & 1471 & 9,04 & 3,43 \\
\hline Materiais Inconsolidados 11 & 3873 & 198 & 1,22 & 5,11 \\
\hline Materiais Inconsolidados 12 & 402 & 0 & 0,00 & 0,00 \\
\hline Materiais Inconsolidados 13 & 63571 & 2079 & 12,78 & 3,27 \\
\hline Materiais Inconsolidados 14 & 2227 & 67 & 0,41 & 3,01 \\
\hline Materiais Inconsolidados 15 & 20470 & 1839 & 11,31 & 8,98 \\
\hline Materiais Inconsolidados 16 & 38528 & 1821 & 11,19 & 4,73 \\
\hline Materiais Inconsolidados 17 & 6122 & 116 & 0,71 & 1,89 \\
\hline Materiais Inconsolidados 18 & 17631 & 671 & 4,12 & 3,81 \\
\hline Materiais Inconsolidados 19 & 5972 & 349 & 2,15 & 5,84 \\
\hline Materiais Inconsolidados 20 & 137974 & 4023 & 24,73 & 2,92 \\
\hline Materiais Inconsolidados 21 & 5810 & 130 & 0,80 & 2,24 \\
\hline Pot Agrícola Favorável & 95286 & 2373 & 14,59 & 2,49 \\
\hline Pot Agrícola Moderado & 289646 & 9302 & 57,18 & 3,21 \\
\hline Pot Agrícola Severo & 52747 & 1158 & 7,12 & 2,20 \\
\hline Pot Agrícola Restrito & 2382 & 73 & 0,45 & 3,06 \\
\hline Uso Agrícola Proibido & 96701 & 3189 & 19,60 & 3,30 \\
\hline
\end{tabular}


TABELA 6.6 - Relação entre os setores destinados as áreas urbanizadas e as diversas classes/unidades presentes nas cartas de declividades e potencial agrícola e nos mapas de substrato rochoso e materiais inconsolidados.

\begin{tabular}{|c|c|c|c|c|}
\hline & $\begin{array}{l}\text { Número } \\
\text { de Pixels }\end{array}$ & $\begin{array}{l}\text { Número de } \\
\text { Pixels } \\
\text { Coincidentes } \\
\text { com a Zona } \\
\text { Urbana } \\
\end{array}$ & \begin{tabular}{|c|} 
Percentual da \\
Superfície de Zona \\
Urbana que as \\
classes/unidades \\
Ocorrem \\
\end{tabular} & $\begin{array}{c}\text { Percentual de } \\
\text { Zona Urbana } \\
\text { que as } \\
\text { classes/unidades } \\
\text { Apresentam } \\
\end{array}$ \\
\hline ZONA URBANA & 24656 & - & \begin{tabular}{|c|}
- \\
\end{tabular} & - \\
\hline Declivi Men que $2 \%$ & 10373 & 1748 & 7,09 & 16,85 \\
\hline Declivi de 2 a $5 \%$ & 47541 & 3801 & 15,42 & 8,00 \\
\hline Declivi de 5 a $10 \%$ & 86075 & 5477 & 22,21 & 6,36 \\
\hline Declivi de 10 a $15 \%$ & 79272 & 4035 & 16,37 & 5,09 \\
\hline Declivi de 15 a $20 \%$ & 75510 & 3674 & 14,90 & 4,87 \\
\hline Declivi de 20 a $25 \%$ & 65662 & 2312 & 9,38 & 3,52 \\
\hline Declivi de 25 a $30 \%$ & 45954 & 1326 & 5,38 & 2,89 \\
\hline Declivi de 30 a $47 \%$ & 110906 & 2182 & 8,85 & 1,97 \\
\hline Declivi de Mai $47 \%$ & 15469 & 92 & 0,37 & 0,59 \\
\hline Fonólitos e Tinguaítos & 52643 & 11837 & 48,01 & 22,49 \\
\hline Nefelina Sienitos & 57354 & 11391 & 46,20 & 19,86 \\
\hline Charnockitos & 86416 & 0 & 0,00 & 0,00 \\
\hline Granulitos Quart-feldsp & 74057 & 0 & 0,00 & 0,00 \\
\hline Migmatitos Graní e Estrom & 260483 & 1419 & 5,76 & 0,54 \\
\hline Migmatitos Oftalmíticos & 5808 & 0 & 0,00 & 0,00 \\
\hline Materiais Inconsolidados 01 & 1240 & 0 & 0,00 & 0,00 \\
\hline Materiais Inconsolidados 02 & 2581 & 2119 & 8,59 & 82,10 \\
\hline Materiais Inconsolidados 03 & 45191 & 0 & 0,00 & 0,00 \\
\hline Materiais Inconsolidados 04 & 3598 & 0 & 0,00 & 0,00 \\
\hline Materiais Inconsolidados 05 & 3109 & 233 & 0,95 & 7,49 \\
\hline Materiais Inconsolidados 06 & 17024 & 8279 & 33,58 & 48,63 \\
\hline Materiais Inconsolidados 07 & 28932 & 3325 & 13,49 & 11,49 \\
\hline Materiais Inconsolidados 08 & 49956 & 9272 & 37,61 & 18,56 \\
\hline Materiais Inconsolidados 09 & 39643 & 0 & 0,00 & 0,00 \\
\hline Materiais Inconsolidados 10 & 42901 & 0 & 0,00 & 0,00 \\
\hline Materiais Inconsolidados 11 & 3873 & 0 & 0,00 & 0,00 \\
\hline Materiais Inconsolidados 12 & 402 & 0 & 0,00 & 0,00 \\
\hline Materiais Inconsolidados 13 & 63571 & 0 & 0,00 & 0,00 \\
\hline Materiais Inconsolidados 14 & 2227 & 0 & 0,00 & 0,00 \\
\hline Materiais Inconsolidados 15 & 20470 & 0 & 0,00 & 0,00 \\
\hline Materiais Inconsolidados 16 & 38528 & 0 & 0,00 & 0,00 \\
\hline Materiais Inconsolidados 17 & 6122 & 0 & 0,00 & 0,00 \\
\hline Materiais Inconsolidados 18 & 17631 & 0 & 0,00 & 0,00 \\
\hline Materiais Inconsolidados 19 & 5972 & 0 & 0,00 & 0,00 \\
\hline Materiais Inconsolidados 20 & 137974 & 1419 & 5,76 & 1,03 \\
\hline Materiais Inconsolidados 21 & 5810 & 0 & 0,00 & 0,00 \\
\hline Pot Agrícola Favorável & 95286 & 7075 & 28,69 & 7,43 \\
\hline Pot Agrícola Moderado & 289646 & 12633 & 51,24 & 4,36 \\
\hline Pot Agrícola Severo & 52747 & 1883 & 7,64 & 3,57 \\
\hline Pot Agrícola Restrito & 2382 & 0 & 0,00 & 0,00 \\
\hline Uso Agrícola Proibido & 96701 & 3056 & 12,39 & 3,16 \\
\hline
\end{tabular}


$>$ Quase metade dos setores que apresentam proibição à prática agrícola $(48,56$ $\%$, com base no código florestal brasileiro, são destinados à pecuária bovina extensiva.

$>$ Cerca de $51,73 \%$ do percentual de áreas de pasto desenvolvem-se onde o substrato rochoso presente é composto por migmatitos graníticos e estromatíticos.

$>$ Mais da metade das áreas de pastagens $(54,45 \%)$ estão associadas a classe de potencial agrícola moderado.

Quanto as áreas ocupadas por café:

$>$ Predominam em mais de $50 \%$ sobre materiais inconsolidados residuais de granulitos quartzo-fedspáticos pertencentes ao grupo textural VI apresentando espessuras superiores a $3,0 \mathrm{~m}$.

Aproximadamente 23,46 \% dos setores que apresentam proibição à prática agrícola (código florestal) são destinados a monocultura cafeeira.

Mais da metade das áreas onde o café é plantado o substrato rochoso presente é formado por migmatitos graníticos e estromatíticos.

$>$ Mais de $50 \%$ dos setores onde o café é cultivado apresentam potencial agrícola moderado.

* Quanto as áreas ocupadas por mata nativa:

$>$ São maioria nos materiais inconsolidados (mais de $50 \%$ ):

- residuais de fnólitos e tinguaítos pertecentes ao grupo textural III com espessuras variando entre 0,5 e $1,5 \mathrm{~m}$.

- residuais de fonólitos e tinguaítos pertecentes ao grupo textural VIII apresentando espessuras superiores a 3,0 m.

Somente em 16,62 \% dos setores destinados a preservação da vegetação nativa possuem floresta mesófila.

$>$ Mais da metade das áreas de mata nativa $(53,13 \%)$ estão associadas a classe de potencial agrícola moderado.

- Quanto as áreas ocupadas por solo exposto:

$>$ Cerca de 3,30 \% dos setores que apresentam proibição à prática agrícola não apresentam nenhuma cobertura vegetal. 
$>$ A maior parte das áreas sem cobertura vegetal $(60,79 \%)$ tem como substrato rochoso associado os migmatitos graníticos e estromatíticos.

$>$ Mais de $50 \%$ das áreas que apresentam solo exposto estão associadas à classe de potencial agrícola moderada.

- Quanto as áreas ocupadas por zonas urbanas:

Até $82,10 \%$ da superfície da áreas estudada que contém materiais inconsolidados retrabalhados pertencentes ao grupo textural VI de origem aluvionar com espessuras inferiores a 0,5m estão urbanizados.

Somente $3,16 \%$ da classe proibida de aptidão agrícola (baseada no código florestal) está presente a zona urbana

$>$ A maior parte dos centros urbanos (mais de $50 \%$ ) estende-se pela classe moderada de potencial agrícola.

A avaliação individual da distribuição das diferentes formas de uso e ocupação em cada unidade geoambiental encontra-se presente no ANEXO X. Este conta ainda, a exemplo do ANEXO IX, com outras informações levantadas sobre meio físico.

Por fim, tentou-se estabelecer correlações entre os diversos padrões de uso e ocupação da área sobre as unidades geoambientais. Desse modo, foram realizadas regressões lineares considerando a superfície ocupada por cada unidade do mapa de uso e ocupação (excetuando a classe de água represada) sobre as diferentes unidades geoambientais por meio do STATISTICA® 5.5 .

Os resultados obtidos apontaram a presença de baixos coeficientes de correlação (Tabela 6.7). Entretanto, variáveis como percentuais de café e solo exposto parecem apresentar alguma relação, ainda que pouco consistente, para algumas das unidades geoambientais, conforme mostra a Figura 6.8.

Este tipo de análise embora não indique que exista uma relação de causa e efeito entre as variáveis, mesmo para coeficientes de correlações elevados, pode ser muito interessante para orientar estudos sobre aspectos de ocupação e eventualmente de degradação ambiental da área. 
TABELA 6.7 - Matriz de correlação obtida por regressão linear entre o percentual de superfície que cada unidade de uso e ocupação possui para as diferentes unidades geoambientais.

\begin{tabular}{|c|c|c|c|c|c|}
\cline { 2 - 6 } \multicolumn{1}{c|}{} & Mata Nativa & Pastagem & Solo Exposto & Café & Zona Urbana \\
\hline Mata Nativa & 1,00 & $-0,34$ & $-0,33$ & $-0,18$ & $-0,23$ \\
\hline Pastagem & $-0,34$ & 1,00 & 0,17 & $-0,23$ & $-0,43$ \\
\hline Solo Exposto & $-0,33$ & 0,17 & 1,00 & $\mathbf{0 , 5 3}$ & $-0,46$ \\
\hline Café & $-0,18$ & $-0,23$ & $\mathbf{0 , 5 3}$ & 1,00 & $-\mathbf{0 , 5 4}$ \\
\hline Zona Urbana & $-0,23$ & $-0,43$ & $-0,46$ & $\mathbf{- 0 , 5 4}$ & 1,00 \\
\hline
\end{tabular}

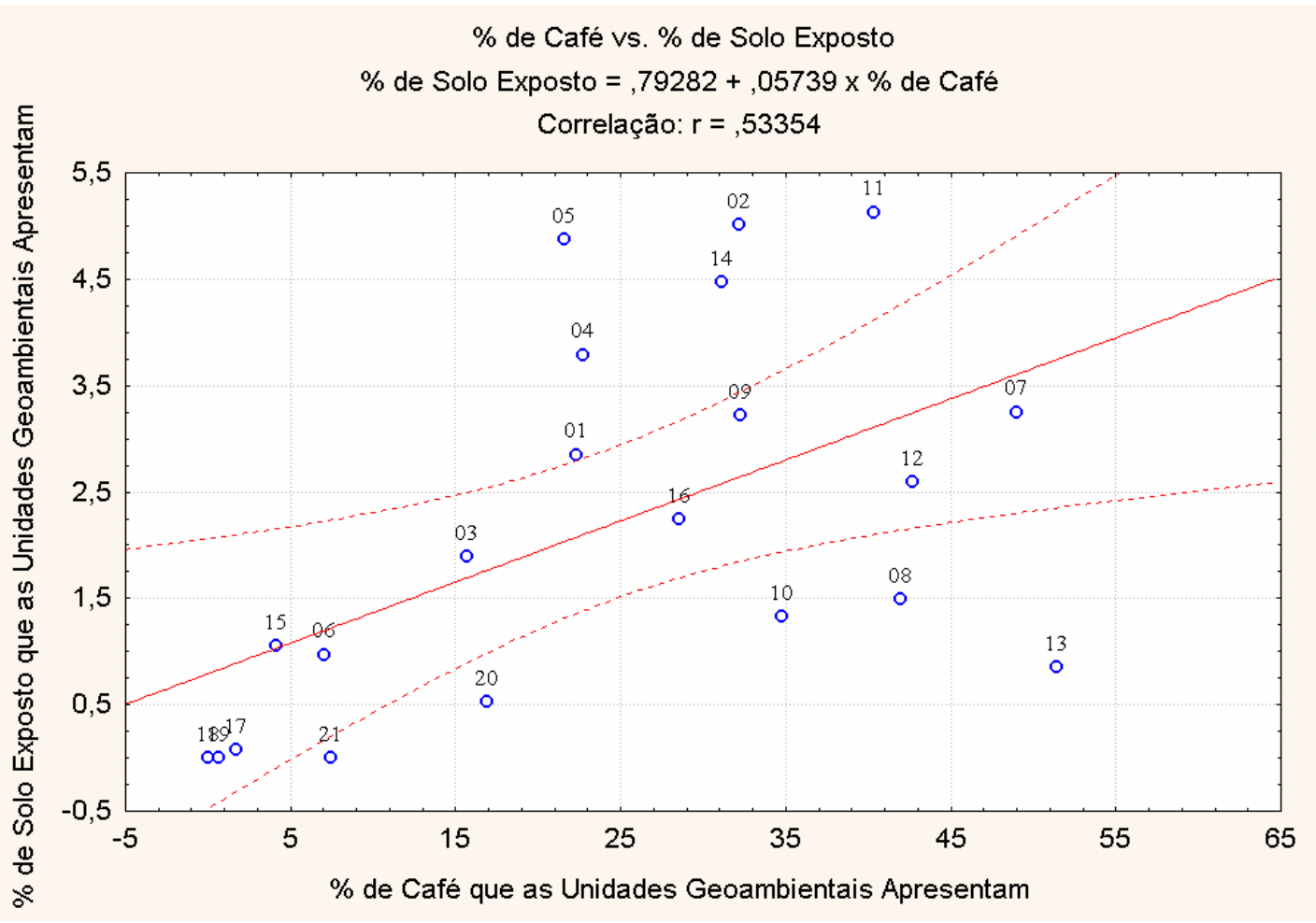

FIGURA 6.8 - Regressão linear entre o percentual de superfícies ocupadas por café e o percentual de superfícies que apresentam solo exposto nas 21 Unidades Geoambientais analisadas. 


\section{CAPÍTULO 7 - CONCLUSÕES E RECOMENDAÇÕES}

\subsection{Conclusões}

\subsubsection{Quanto a Metodologia de Zoneamento Geoambiental}

Os procedimentos e os produtos da cartografia geotécnica proposta por Zuquette (1987), Zuquette \& Gandolfi (1990), Zuquette (1993) e Zuquette et al. (1997) mostraram-se bastante adequados nessa pesquisa para o estabelecimento do zoneamento geoambiental da área estudada.

O sucesso obtido na confecção da carta geoambiental ocorreu pois tal proposta metodológica permitiu a produção e análise de um conjunto de documentos cartográficos que objetivaram representar o meio físico por meio dos seus principais atributos. A partir desses documentos, o zoneamento geoambiental da área em estudo foi estabelecido em função do cruzamento dos dados contidos nos produtos cartográficos, desse modo, aproveitando a informação geotécnica gerada na pesquisa.

A análise de agrupamentos dos componentes do meio físico, técnica não prevista na metodologia, quando associada a análise espacial utilizando geoprocessamento, mostrourse muito importante para a delimitação das unidades que compõem a carta geoambiental.

Tal técnica auxiliou a definição de setores que apresentaram, quando analisados individualmente, homogeneidade quanto aos aspectos do meio físico levantados, em termos geomorfológicos (carta de declividades e mapa de landforms), geológicos (mapa de substrato rochoso), de "solos" (mapa de materiais inconsolidados) e de suas aptidões (carta de potencial agrícola). 
Por outro lado, a análise de agrupamentos permitiu que as unidades geoambientais delimitadas, quando avaliadas na sua totalidade, possuíssem um comportamento heterogêneo de modo que cada um de seus setores exibissem características bem particulares relacionadas aos componentes do meio físico avaliados.

\subsubsection{Quanto ao Geoprocessamento das Informações}

O geoprocessamento das informações colecionadas ao longo da pesquisa, prestou grande contribuição à realização deste trabalho, permitindo que vários atributos da área em estudo fossem medidos, calculados, analisados, comparados, combinados ou simplesmente visualizados.

No entanto, o geoprocessamento realizado envolveu o uso de diversos softwares (AutoCad Map 2000, dxf2xyz 1.3, Microsoft Excel, Envi 3.2, Statistica 5.5 e Surfer 7.0) além dos sistemas de informações geográficas Idrisi 32 e ArcView GIS 3.1 o que resultou num acréscimo excessivo no tempo gasto para o desenvolvimento da pesquisa, uma vez que a aprendizagem e familiarização de tais softwares se desenvolveu em um longo período de tempo. Isto se tornou necessário, em função de se buscar neste trabalho utilizar os componentes de análise de cada software mais apropriados aos estudos realizados.

\subsubsection{Quanto aos Resultados Obtidos no Zoneamento Geoambiental}

A confecção da carta geoambiental foi realizada com sucesso atendendo aos critérios exigidos pela metodologia desenvolvida. Nela foram delimitadas 21 unidades geoambientais tomando como base o cruzamento e análise de agrupamentos dos diversos planos de informações produzidos.

Além disso, todos os produtos cartográficos gerados na pesquisa, encontramse inseridos nos sistemas de informações geográficas Idrisi 32 e ArcView GIS 3.1, onde este último associa aos mapas e cartas confeccionados um banco de dados geoambiental de modo a possibilitar que as informações possam ser acrescidas, inseridas, recuperadas, atualizadas ou simplesmente removidas desde que se queira ou se faça necessário. 


\subsection{Recomendações}

Para o zoneamento estabelecido nessa pesquisa foi levado somente em consideração aspectos do meio físico de natureza geomorfológica, geológica, de "solos" e aptidões ao uso e ocupação antrópica, contudo um estudo geoambiental completo, na visão deste trabalho, deve abranger também aspectos relacionados a susceptibilidade ao desenvolvimento de processos de dinâmica superficial (erosão, movimentos de massa, assoreamento, inundações, subsistência, colapsos, etc.), vulnerabilidades e riscos de acidentes geológico-geotécnicos.

Desse modo, é necessário nesse caso, analisar não somente o meio físico mas também o meio antrópico, de maneira a examinar como as formas diversificadas de uso e ocupação afetam o desenvolvimento das susceptibilidades, vulnerabilidades e riscos de acidentes geológico-geotécnicos.

Dessa forma, acredita-se que uma vez incluídos todos esses aspectos, seria possível avaliar a metodologia de zoneamento desenvolvida frente a uma caracterização completa do ponto de vista geoambiental.

Durante o processamento das informações o aprendizado e a familiarização com os softwares "específicos" utilizados resultaram num acréscimo excessivo no tempo gasto no desenvolvimento da pesquisa. Entretanto, sempre que se faça necessário eles devem ser utilizados, uma vez que para várias das tarefas de geoprocessamento (digitalização, geração do MDT, processamento digital de imagens, análise estatística, etc), apresentam opções de execução que são melhores e mais diversificadas em relação aos vários sistemas de informações geográficas presentes no mercado. 


\section{REFERÊNCIAS BIBLIOGRÁFICAS}

AGUIAR, M.B.; KRELING, P.C.L. Elaboração gráfica de carta de declividade de vertentes. Revista do Departamento de Geografia. São Paulo, v.3, p. 109 - 116, 1984.

ASSOCIAÇÃO BRASILEIRA DE NORMAS TÉCNICAS. NBR 6508. Grão que passam na \# 4,8 mm, determinação de massa específica.

ASSOCIAÇÃO BRASILEIRA DE NORMAS TÉCNICAS. NBR 7181. Solo Análise granulométrica.

ASWATHANARAYANA, U. Geoenvironment an Introduction Holanda, Balkema, 1995.

BITAR, O.Y.; ORTEGA, R.D.Gestão ambiental. In: OLIVEIRA, A.M. dos S.; BRITO, S.N.A. de. Geologia de engenharia. São Paulo, ABGE. 1998. Cap.32, p.499- 508 .

BJÖRNBERG. Arenitos do bordo do Planalto de Poços de Caldas. Anais da Academia Brasileira de Ciências. Rio de Janeiro. v.28, n4, p. 465 - 471, 1956.

BJÖRNBERG. Rochas clásticas do Planalto de Poços de Caldas. Boletim Geologia. Faculdade de Filosofia, Ciência e Letras da USP, São Paulo, 237, n18, p. 65 $122,1959$.

BRASIL. Lei n. 4.471 de 15 de setembro de 1965. Institui o Código Florestal. 
BRASIL. Lei no 6.766 de 19 de dezembro de 1979. Dispõe sobre o Parcelamento do Solo Urbano.

CALIJURI, M.L. Sistema de Informações geográficas. In: CASTELLANO, E.G.; CHAUDHRY, F.H. Desenvolvimento sustentado: Problemas e Estratégias. São Carlos, EESC - USP. 2000. Cap. 16,p.275 - 283.

CAMARA, G.; DAVIS, C. Introdução. In: CÂMARA, G et al.. Geoprocessamento: $\begin{array}{lllll}\text { Teoria } & \text { e } & \text { Aplicações } & \text { (livro } & \text { on-line). }\end{array}$ http://www.dpi.inpe.br/gilberto/livro/cap1-introducao.pdf. Acesso agosto de 2000.

CAVALCANTE, J.C.; CUNHA, H.C. da S.; CHIEREGATI, L.A.; KAEFER, L.Q.; ROCHA, J.M. da; DAITX, E.C.; COUTINHO, M.G. da N.; YAMAMOTO, K.; DRUMOND, J.B.V.; ROSA, D.B.; RAMALHO, R.. Projeto Sapucaí. Brasília: MME/DNPM. Séria Geologia no 4. Seção Geologia Básica no 2. 299p, 1979.

CENDRERO, A. \& DÍAZ de TERÁN. The environmental map system of the University of Cantabria Spain. In: ARNDT, P. \& LÜTTIG, G.; Mineral Resources Extraction, Environmental Protection and Land-Use Planning in the Industrial Developing Countries. Stuttgart, E. Schweizebart-Verlag. 1987. p. 149-181.

CENDRERO, A. Environmental geology of the Santander Bay Area, Norhern Spain. Engineering Geology. v. 1, p. 97 - 114. 1975.

CENDRERO, A.; NIETO, M.; ROBLES F.; SÁNCHES J.; DÍAZ de TERÁN, J.R.; FRANCÉS, E.; GONZÁLES-LASTRA, J.R.; BOLUDA, R.; GARAY, P.; GUTIÉRREZ, G.; JIMÉNEZ, J.; MARTÍNEZ, J.; MOLINA, M.J.; OBARTÍ, J.; PEREZ, A.; PONS, V.; SANTONHOA A.; STÜBING, G. Mapa Geocientífico de la Provincia de Valencia. Diputación Provincial de Valencia. Valencia. 1986. $350 \mathrm{p}$. 
CENDRERO, A.; SÁNCHEZ, J.; ANTOLÍN, A.; ARNAL, S.; DÁZ de TERÁN, J.R.; FRANCÉS, E.; MARTÍNEZ, A.; MOÑINO, M.; NIETO, M.; NOGALES, I.; PÉREZ, E.; RIOS, C.; ROBLES, F.; ROMERO, A.; SUÁREZ, C. Geoscientific maps for planning in semi-arid regions: Valencia and Gran Canaria, Spain. Engineering Geology, v. 29, p. 291 - 319. 1990.

CHAUDHRY, F.H. Aproveitamento de recursos hídricos. In: CASTELLANO, E.G.; CHAUDHRY, F.H. Desenvolvimento Sustentado: Problemas e Estratégias. São Carlos, EESC - USP. 2000. Cap. 3,p.27 - 37.

CHRISTIAN, C.S. \& STEWART, G.A. Methodology of integrated surveys. In: UNESCO, Aerial Surveys and Integrated Studies. Paris. 1968. p.233 - 280.

CHRISTOFOLETTI, A. Geomorfologia. São Paulo. Edgard Blücher, 1974.

COLLARES, Eduardo Goulart. Avaliação de alterações em redes de drenagem de microbacias como subsídio ao zoneamento geoambiental de bacias hidrográficas: aplicação na bacia hidrográfica do Rio Capivari - SP. 2000. 2v. Tese Doutorado - Escola de Engenharia de São Carlos, Universidade de São Paulo, São Carlos.

COOKE, R.U. \& DOORNKAMP, J.C. Mapping Geomorphology. In

Geomorphology in Environmental Management : a new introduction. 2.ed. New York: Claredon Press, 1990. cap. 2, p. 19-63.

CUNHA S.B. da; GUERRA, A.J.T. Degradação ambiental. In: GUERRA, A.J.T. CUNHA S.B. da; Geomorfologia e Meio Ambiente. Brasil: Bertrand Brasil, 1996. Cap. 7, p337- 379.

DAI, FC.; LEE, C.F.; ZHANG, X.H. GIS-based geo-environmental evaluaion for urban land-use planning: a case study. Engineering Geology. Elsevier. 61. p. 257-271, 2001.

DANTAS, M.E. Diagnóstico geoambiental do Estado do Rio de Janeiro. (CDROOM). Rio de Janeiro. 2000. Companhia de Pesquisa de Recursos Minerais. 
DAVIS, C.; CÂMARA, G. (1999). Arquitetura de sistemas de informação geográfica. In: CÂMARA, G. et al.. Geoprocessamento: Teoria e Aplicações (livro on-line). 1999. http://www.dpi.inpe.br/gilberto/livro/cap3-arquitetura.pdf. . Acesso agosto de 2000.

DE BIASI, M. A carta clinográfica: os métodos de representação e sua confecção. Revista do Departamento de Geografia. São Paulo n.6, p. 45 - 53, 1992.

DE BIASI, M. Cartas de declividade: confecção e utilização. Geomorfologia. São Paulo, v.21, p.8 - 13, 1970.

DE VILOTA, I.; DE LUXÁN, M.; GOY, J.L.; BUSTAMANTE, I.; ZAZO, C.; Geoenvironmental mapping applied to urban settlements: La Vall de Gallinera, Alicante, Spain. In: BOBROWSKY, P.T. Geoenvironmental Mapping. Victoria, School of Earth and Ocean Sciences - University of Victoria. 2002. p. $452-471$.

DIAS, R.W. Planos diretores de geoprocessamento: desenvolvimento e aplicações.

In: CONFERÊNCIA LATINOAMERICANA SOBRE SISTEMAS DE INFORMAÇÃO GEOGRÁFICA, 4 e SIMPÓSIO BRASILEIRO DE GEOPROCESSAMENTO, 2, São Paulo, 1993. Anais .... p. 687 - 707.

DINIZ, N.C.; CINTRA, J.P.; ALMEIDA, M.C.J. de; SALLES, E. R.; COSTA, M.O. Mapeamento geoambiental em base de dados georreferenciados como suporte de análise de riscos e avaliação ambiental regionais. In: CONGRESSO BRASILEIRO DE GEOTECNIA AMBIENTAL, 4, 1999, São José dos Campos. Anais ... São José dos Campos: 1999. p. 49-62.

EASTAMAN, J.R. IDRISI for Windows users's guide version 2.0 introduction. Worcester - MA. Clark University. 1997.

GEOLOGICAL SOCIETY. The description and classification of wethered rocks for engineering purposes. Working Party Report, June 1994. The Quarterly Journal Engineering Geology. v.28, n.2. 38p. 1995. 
GOTHE, C.A. A gestão do meio ambiente no Brasil. In: ENCONTRO NACIONAL DE ESTUDOS AMBIENTAIS, 3, 1991, Londrina. Anais ..., v. 1, p.318 - 331.

GRECCHI, R.C.; PEJON, O.J. Estudos Geoambientais da Região de Piracicaba (SP) com auxílio de imagem de satélite e sistema de informação geográfica. In: SIMPÓSIO BRASILEIRO DE CARTOGRAFIA GEOTÉCNICA, 3, Florianópolis, 1998. Anais ... CD-ROOM. 26p.

GUERRA, A.T. Dicionário Geológico-geomorfológico. 6. ed. Rio de Janeiro. IBGE, 1980.

Guia do ENVI 3.5 em Português (2002). Disponível em: http://www.envi.com.br/guiadoenvi. Acesso em: 16 jan. 2003.

HOWARD, A.D. Drainage analysis in geologic interpretation. Bulletin American Association of Petroleum Geologists. Tulsa, v.54, n11, p. 2246-59, 1967.

IBGE - INSTITUTO BRASILERIRO DE GEOGRAFIA E ESTATÍSTICA (2000).

Censo. Disponível em: www.ibge.gov.br. Acesso em: 13 fev. 2003.

IG - InStituto GeOlÓGICO. Subsídios do Meio Físico-geológico ao

Planejamento do Município de Campinas. São Paulo: Relatório de integração. v.1, 1993.

IPT - INSTITUTO DE PESQUISAS TECNOLÓGICAS DO ESTADO DE SÃO PAULO S.A. Mapa geomorfológico do Estado de São Paulo. São Paulo. Monografia 5. 2v. 1981.

LANDIM, P.M.P. Geologia Quantitativa. Int rodução à Analise Estatística de Dados Geológicos Multivariados. Rio Claro: Instituto de Geociências e Ciências Exatas, Universidade Estadual Paulista, 2001, 93p.

LANNA, A.E.L. Gerenciamento de Bacias Hidrográficas: Aspectos Conceituais e Metodológicos. Brasília. IBAMA, 1995.

LIMA, D de A (1966). Atlas Nacional do Brasil. In: CONGRESSO NACIONAL DE GEOGRAFIA, Rio de Janeiro, 1966. 
LIPORACI, Silvana Ribeiro. Procedimentos e metodologias de mapeamento geotécnico: aplicados na cidade e parte do Município de Poços de Calda (MG) - escala: 1:25000 - visando o planejamento do uso e ocupação do meio físico. 1994. 214p. Dissertação Mestrado - Escola de Engenharia de São Carlos, Universidade de São Paulo, São Carlos.

LOLLO, José Augusto. O uso da técnica de avaliação de terreno no processo no processo de elaboração de mapeamento geotécnico. 1996. 2v. Tese Doutorado - Escola de Engenharia de São Carlos, Universidade de São Paulo, São Carlos.

LOPES, P.M.S.; PEJON, O.J. Estudos dos Atributos do Meio Físico como Base para o Zoneamento Geoambiental das Bacias dos Rios Passa Cinco e Rio da Cabeça São Paulo. In: CONGRESSO BRASILEIRO DE GEOLOGIA DE ENGENHARIA E AMBIENTAL, 10, Ouro Preto, 2002. Anais ... CD-ROOM. $15 \mathrm{p}$.

LOPES, Paulo Maurício Silva. Estudo dos atributos do me io físico como base para o zoneamento geoambiental das bacias dos Rio Passa Cinco e Rio da Cabeça: Escala: 1:50.000. 2000. 136p. Dissertação Mestrado - Escola de Engenharia de São Carlos, Universidade de São Paulo, São Carlos.

Manual do Surfer SURFER ${ }^{\circledR}$ 7.00. User's guide. Contouring and 3D surface mapping for scientists and engineers. Golden Software, Inc, 1999.

MEDEIROS, J.S. de; CÂMARA, G. GIS para estudos ambientais. In: CÂMARA, G. et al. Introdução a Ciência da Geoinformação (livro on-line). 2002. http://www.dpi.inpe.br/gilberto/livro/introd/cap10-aplicacoesambientais.pdf. Acesso maio de 2002.

NOVO. E.M.L.M. Sensoriamento Remoto - Princípios e Aplicação. São Paulo: Edgard Blüchu, 1989. 
OLIVEIRA, M.A.F.; FRANCESCONI, R.; CORDEIRO, C.M.; INGLEZ, A.G.; OLIVEIRA, E.G.; SENA, C.A.S. In: ATLAS DA $1^{\text {a }}$ JORNADA SOBRE A CARTA GEOLÓGICA DO ESTADO DE SÃO PAULO EM 1:50.000. Anais... São Paulo: 1983. p. $171-192$.

PEJON, Osni José. Estudo dos fenômenos de expansão de rochas sedimentares de granulometria fina. Identificação, caracterização e mapeamento. 2000. 197p. Tese Livre Docência - Escola de Engenharia de São Carlos, Universidade de São Paulo, São Carlos.

PEJON, Osni José. Mapeamento geotécnico da folha de Piracicaba-SP (escala 1:100.000): estudo de aspectos metodológicos, de caracterização e de apresentação de atributos. 1992. 2v. Tese Doutorado - Escola de Engenharia de São Carlos, Universidade de São Paulo, São Carlos.

PIRES NETO. Planejamento territorial a abordagem geológico-geotécnica e o conceito de terreno ou abordagem de paisagem. Revista do Departamento de Geografia. n.8, p.51 - 62, 1994.

PIRES, J.S.R.; SANTOS, J.E. dos. Bacias hidrográficas integração entre meio ambiente e desenvolvimento. Ciência Hoje, v.19, n. 110, p.40 - 45, jun 1995.

PROCHNOW, M.C.R. Análise Ambiental da Sub-bacia do Rio Piracicaba: Subsídios ao Seu Planejamento e Manejo. 1990. Tese Doutorado - Intitulo de Geociências e Ciências Exatas, Universidade Estadual Paulista, Rio Claro.

PROJETO RADAMBRASIL. Levantamentos de recursos naturais. Brasília, Ministério de Minas e Energia. Vol 32. 776p. 1983.

ROSS, J.L.S. Geomorfologia aplicada aos EIA(s)-RIMA(s). In: GUERRA, A.J.T. CUNHA S.B. da; Geomorfologia e Meio Ambiente. Brasil: Bertrand Brasil, 1996. Cap. 6, p291 - 336.

ROSS, J.L.S.; DEL PRETTE, M.E. Recursos hídricos e bacias hidrográficas: âncoras do planejamento e gestão ambiental. Revista do Departamento de Geografia. n.12, p.89-121, 1998. 
SALAZAR JUNIOR, O. (1998). O uso de sistemas de informação geográfica na cartografia geotécnica. In: SIMPÓSIO BRASILEIRO DE CARTOGRAFIA GEOTÉCNICA, 3, Florianópolis: 1998. Palestras.

SANCHEZ, M.C. A propósito das cartas de declividade. In: SIMPÓSIO DE GEOGRAFIA FÍSICA APLICADA, 5, 1993, São Paulo. Anais... São Paulo: 1993. p. $311-314$.

SILVA, Sandra Fernandes da. Avaliação das alterações ambientais na sub-bacia hidrográfica do Ribeirão do Piçarrão, Campinas - SP. São Carlos. 2000. 138p. Dissertação Mestrado - Escola de Engenharia de São Carlos, Universidade de São Paulo.

SIMÕES, S.J.C. Geo-indicadores Ambientais Conceitos e Aplicações. Geociências. Rio Claro, v.18, n. 1, p.41 - 52, 1999.

STRAHLER, A N. Quantitative Analysis of Watershed Geomorfology. Trans. Ame. Geophys. New Haven, v38, p.913-20, 1957.

TUNDISI, J.G.Bases ecológicas para o desenvolvimento sustentado. In: CASTELlANO, E.G.; CHAUDHRY, F.H. Desenvolvimento sustentado: Problemas e Estratégias. São Carlos, EESC - USP. 2000. Cap. 1, p.3 - 6.

VEDOVELLO, R.; HOLL, M.C.; MAFFRA, C. de Q.T. Sistemas gerenciadores de informação geoambientais como produto da cartografia geotécnica. Exemplo voltado a disposição de resíduos. In: CONGRESSO BRASILEIRO DE GEOLOGIA DE ENGENHARIA, 9, São Pedro, 1999. Anais ... CD-ROOM. 13p.

ZUQUETTE, L.V.; GANDOLFI, N. Mapeamento geotécnico: uma proposta metodológica. Geociências. Rio Claro, v.9, p.55 - 66, 1990.

ZUQUETTE, L.V.; PEJON, O.J.; GANDOLFI, N.; RODRIGUES, J.E. Mapeamento geotécnico: parte 1 - atributos e procedimentos básicos para elaboração de mapas e cartas. Geociências. Rio Claro, v.16, n.2, p.491 - 524, 1997. 
ZUQUETTE, Lázaro Valentim. Análise crítica da cartografia geotécnica e proposta metodológica para condições brasileiras. 1987. 2v. Tese Livre Docência - Escola de Engenharia de São Carlos, Universidade de São Paulo, São Carlos.

ZUQUETTE, Lázaro Valentim. Importância do mapeamento geotécnico no uso e ocupação do meio físico: fundamentos e guia para elaboração. 1993. 3v. Tese Doutorado - Escola de Engenharia de São Carlos, Universidade de São Paulo, São Carlos. 
ANEXO I - MAPA DE DOCUMENTAÇÃO 


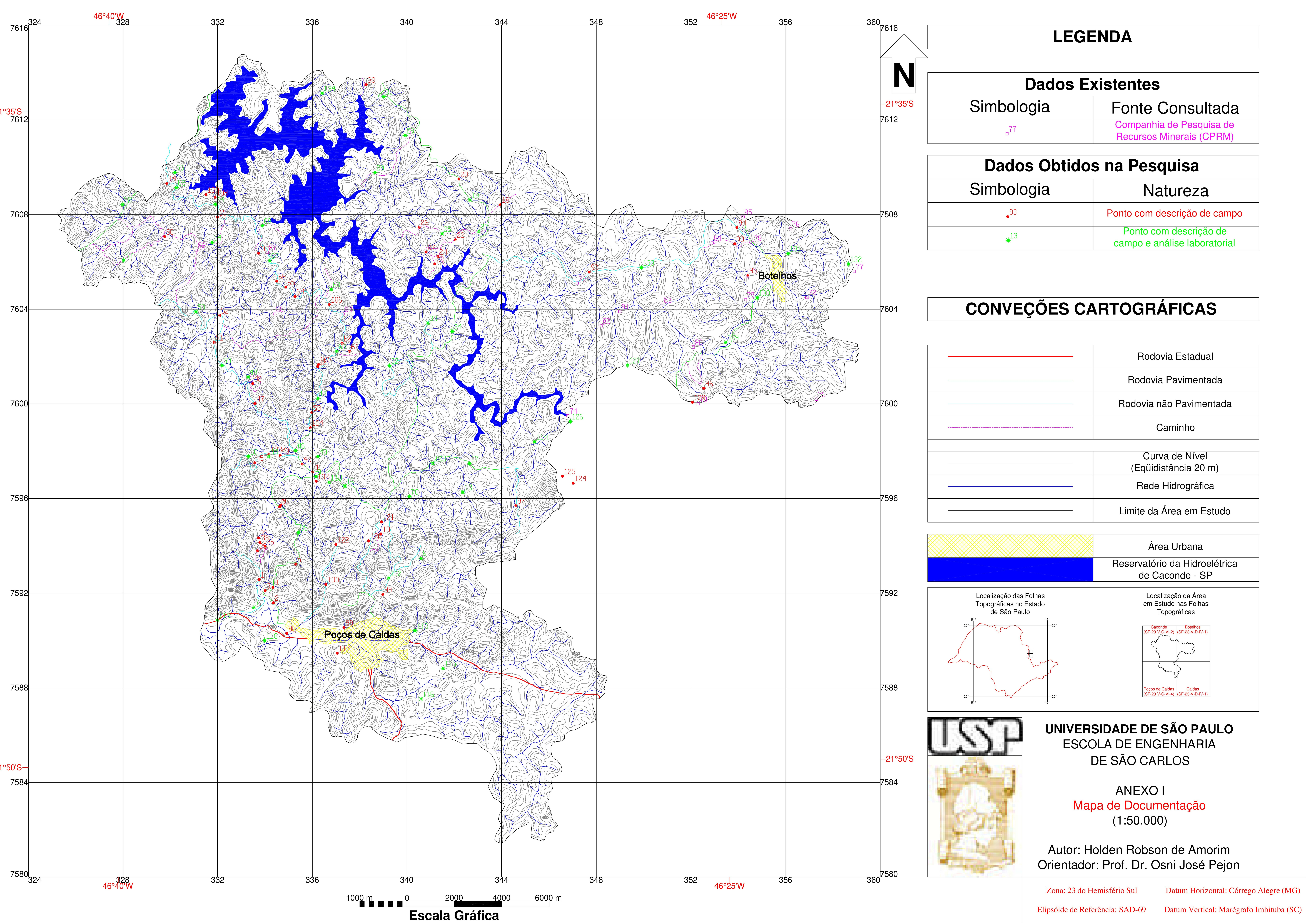


ANEXO II - CARTA DE DECLIVIDADES 


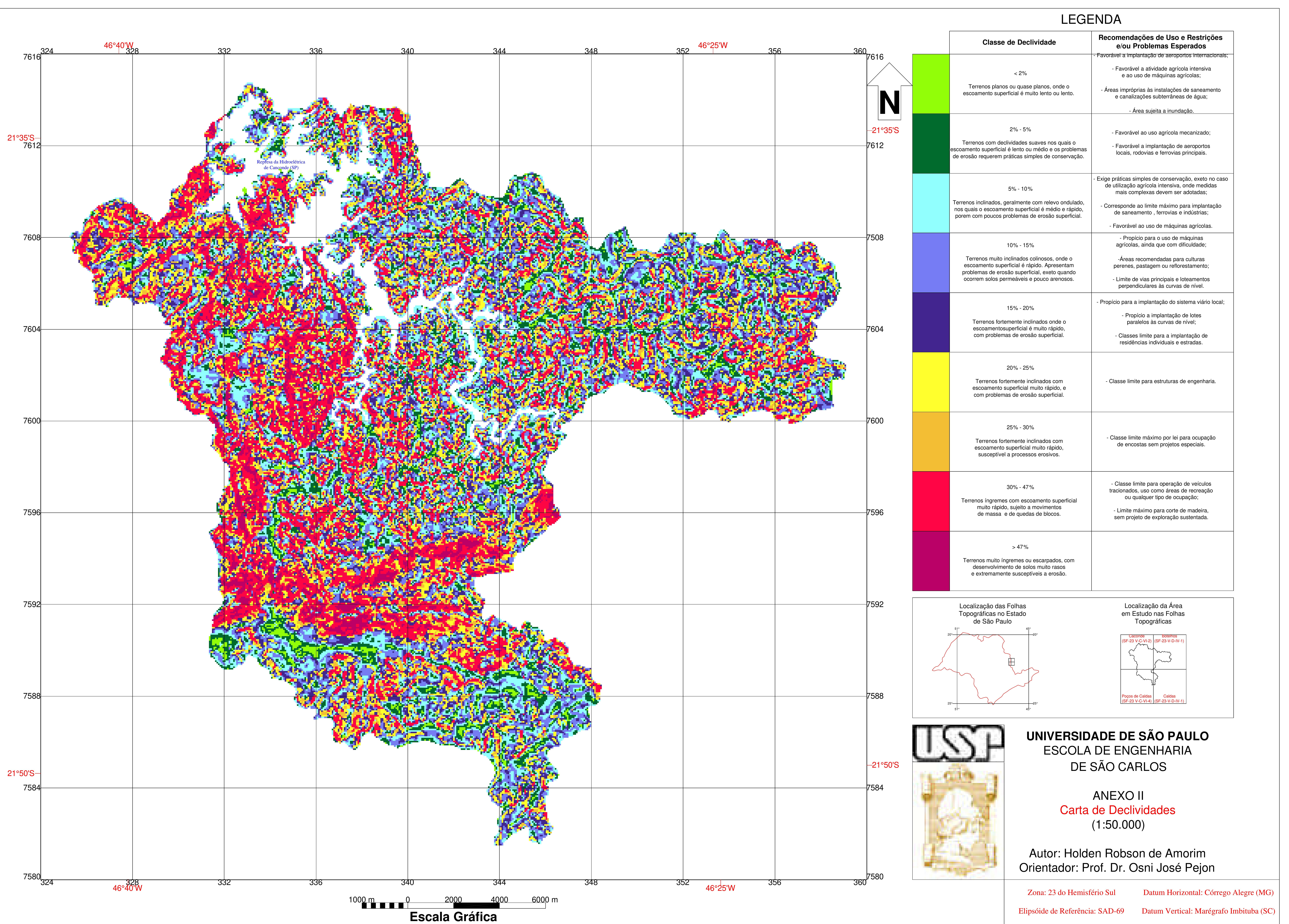


ANEXO III - MAPA DE SUBSTRATO ROCHOSO 


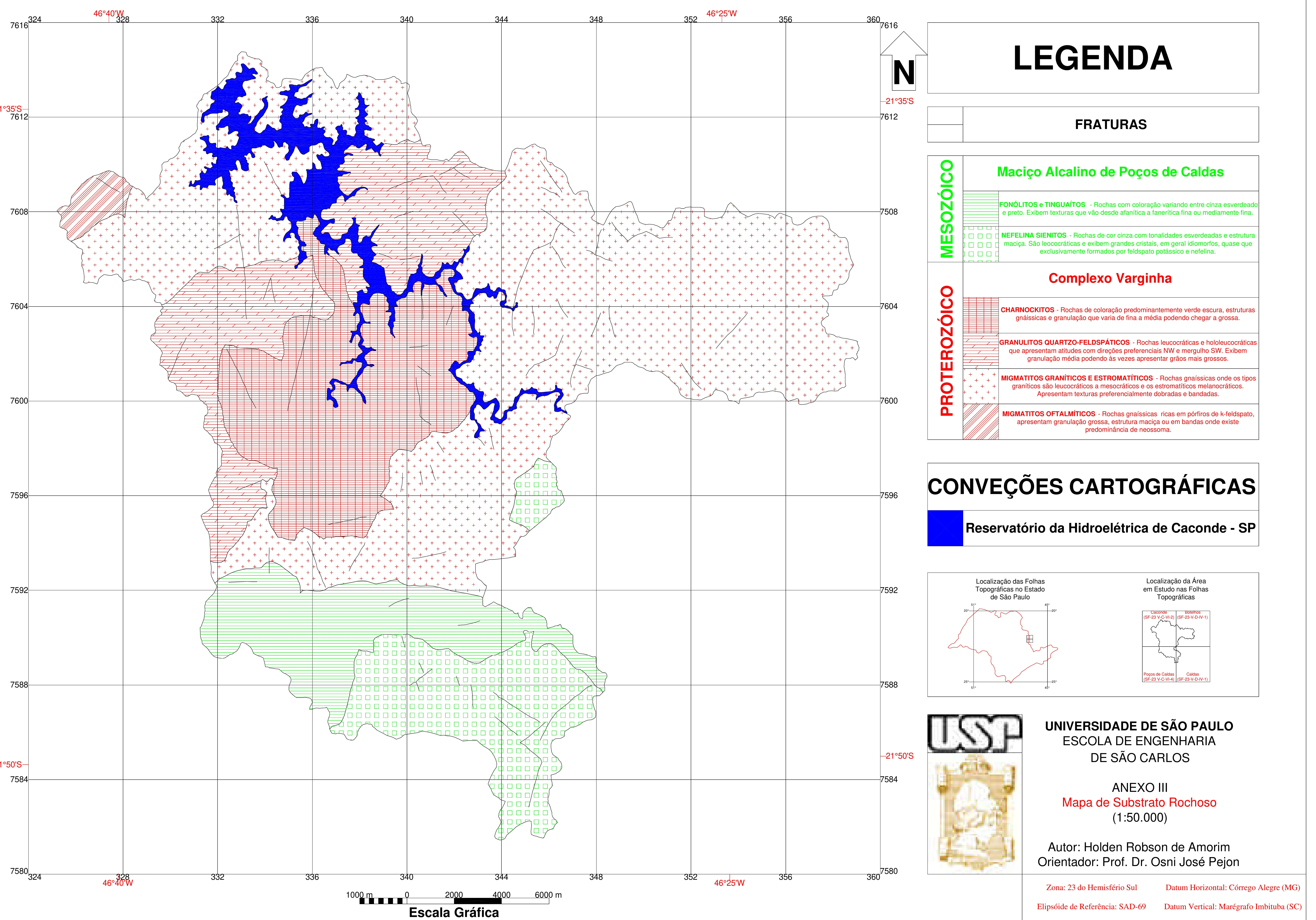


ANEXO IV - MAPA DE MATERIAIS INCONSOLIDADOS 


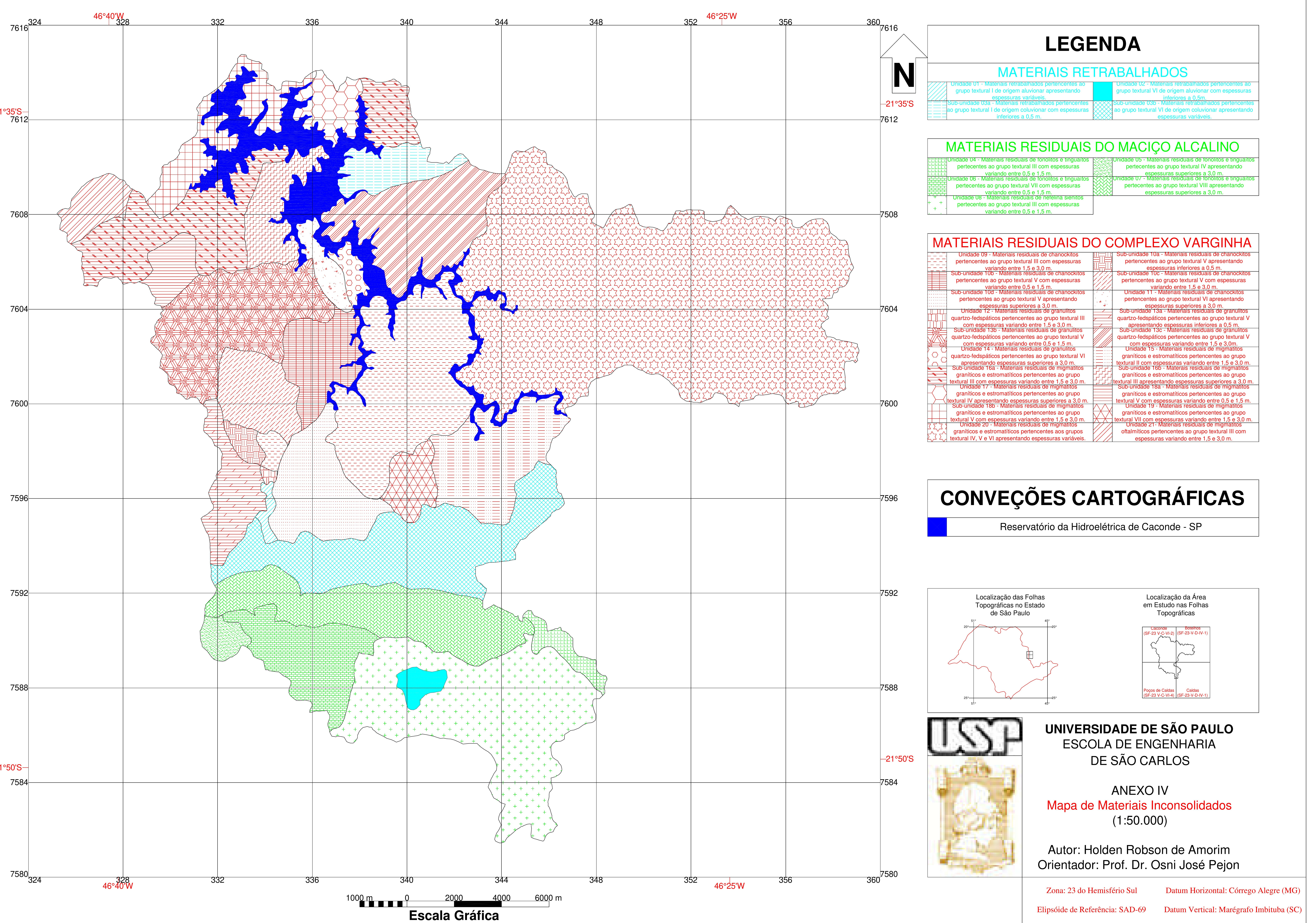


ANEXO V - MAPA DE LANDFORMS 


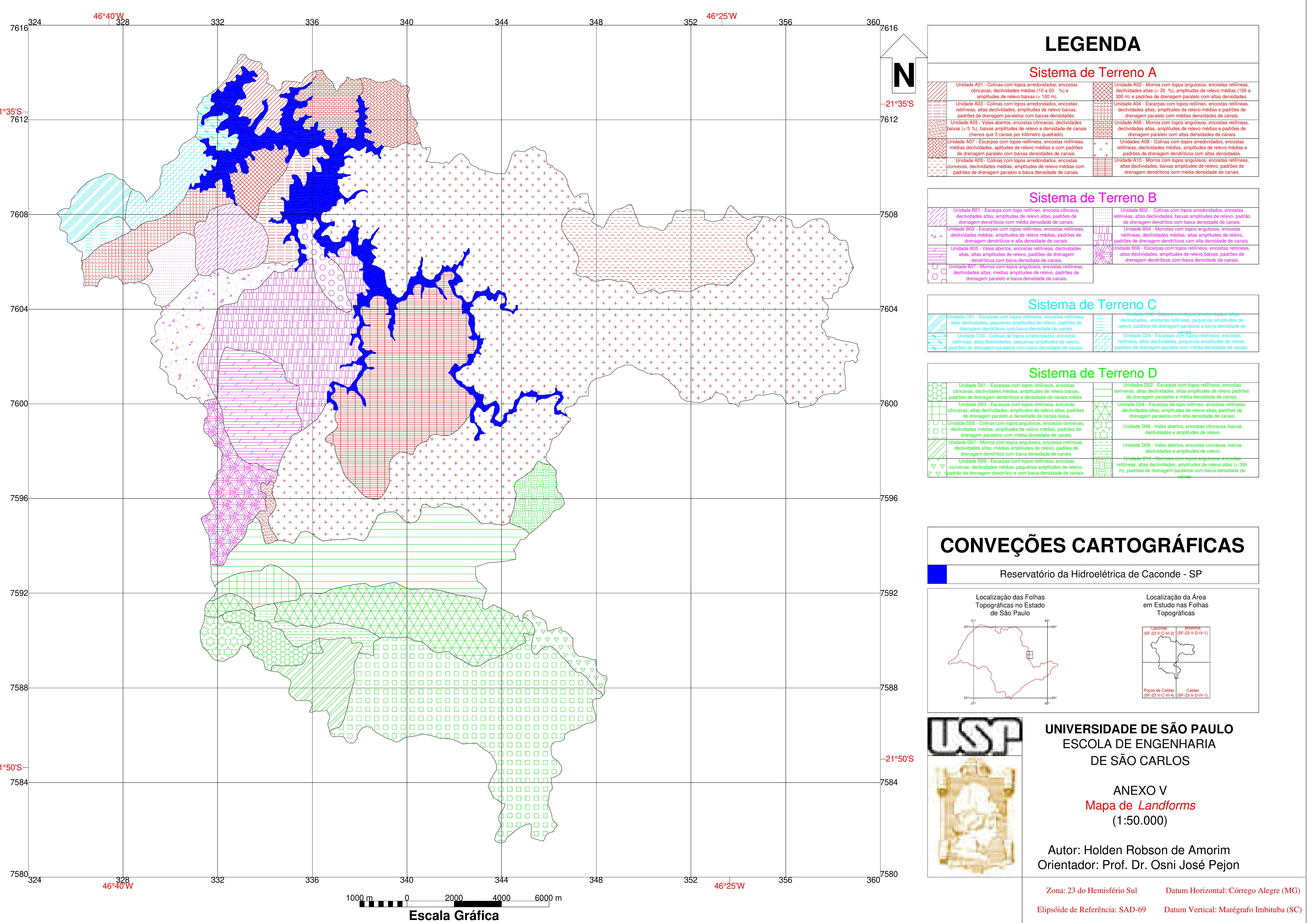


ANEXO VI - MAPA DE USO E OCUPAÇÃO 


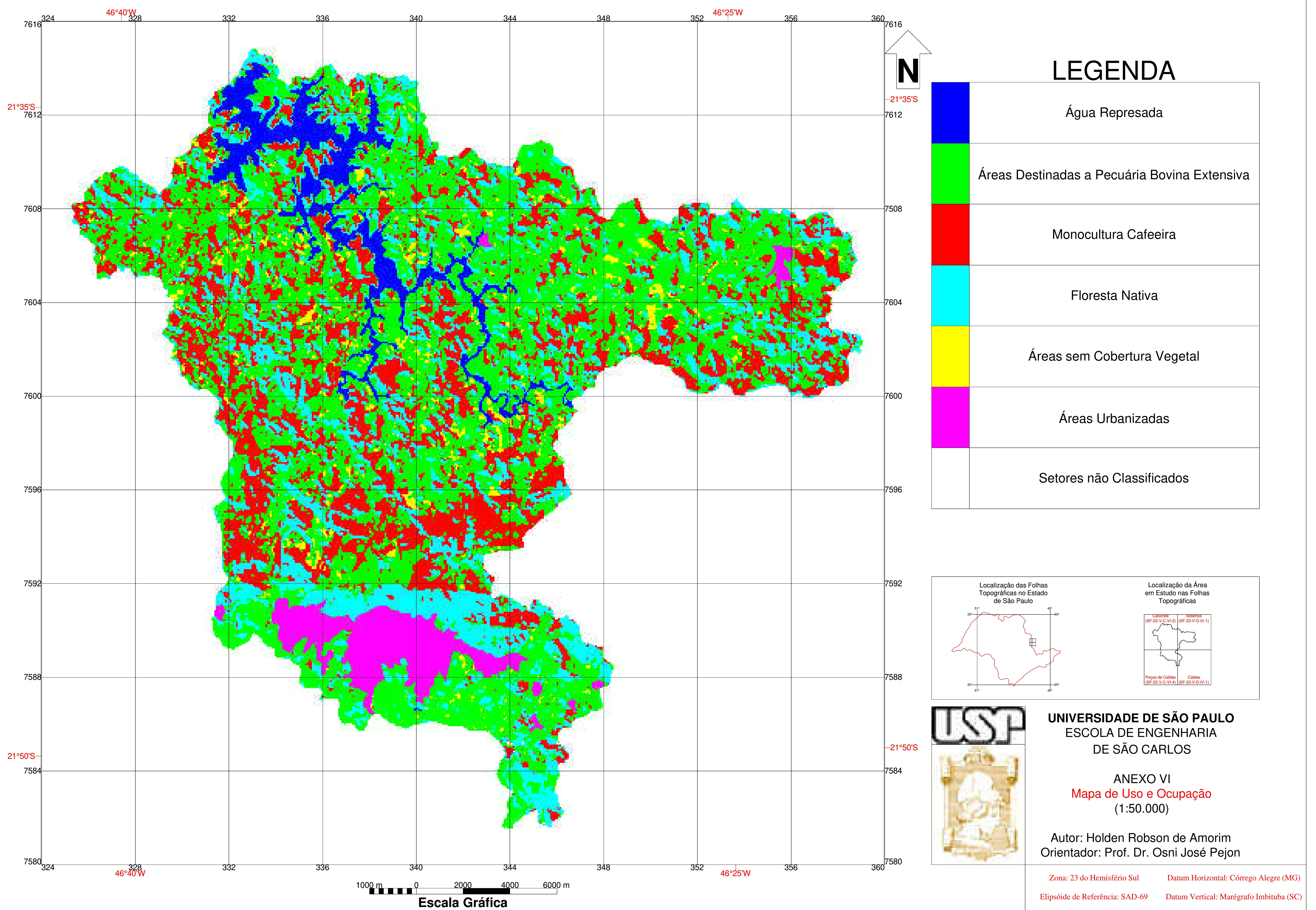


ANEXO VII - CARTA DE POTENCIAL AGRÍCOLA 


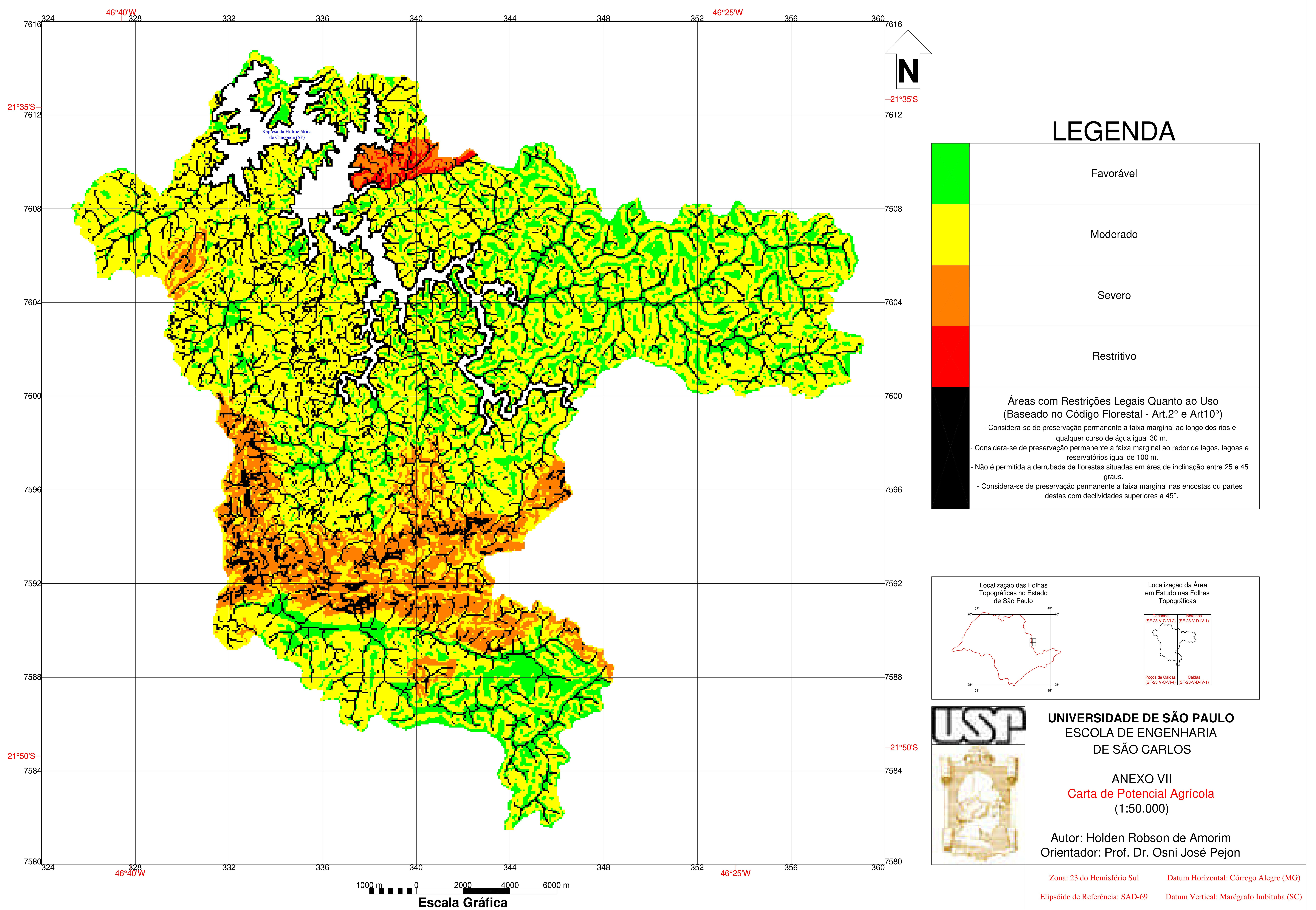


ANEXO VIII - CARTA DE ZONEAMENTO GEOAMBIENTAL 

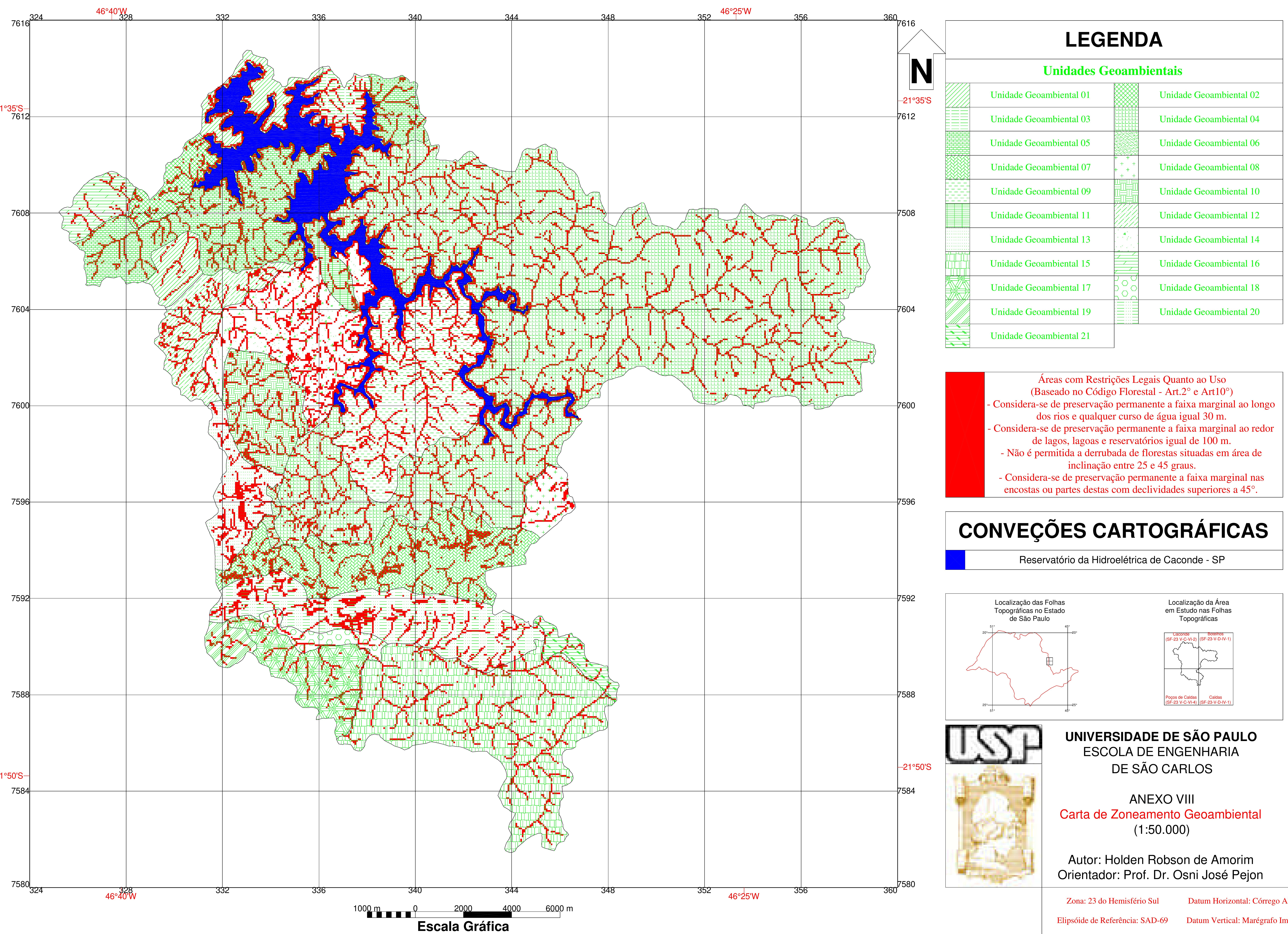

\section{CONVEÇÕES CARTOGRÁFICAS}

Reservatório da Hidroelétrica de Caconde - SP

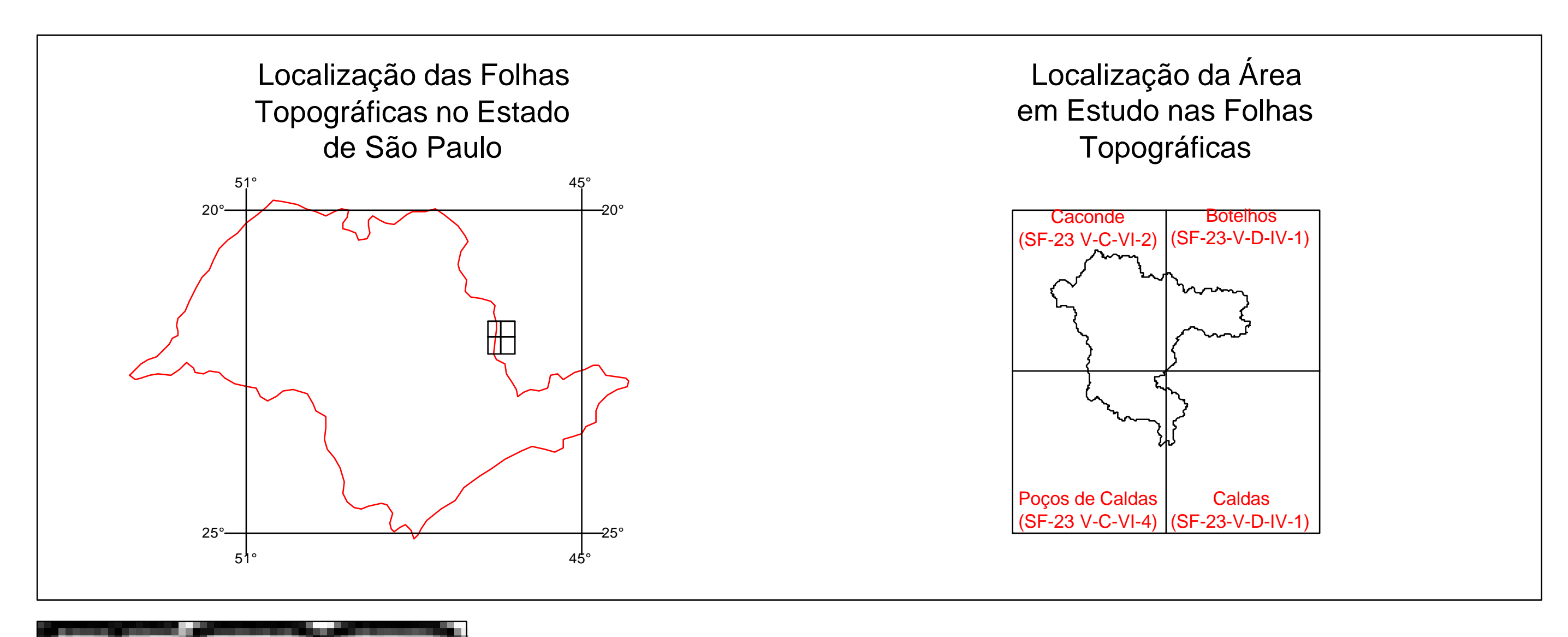
TSן UNIVERSIDADE DE SÃo PAULO DE SÃO CARLOS

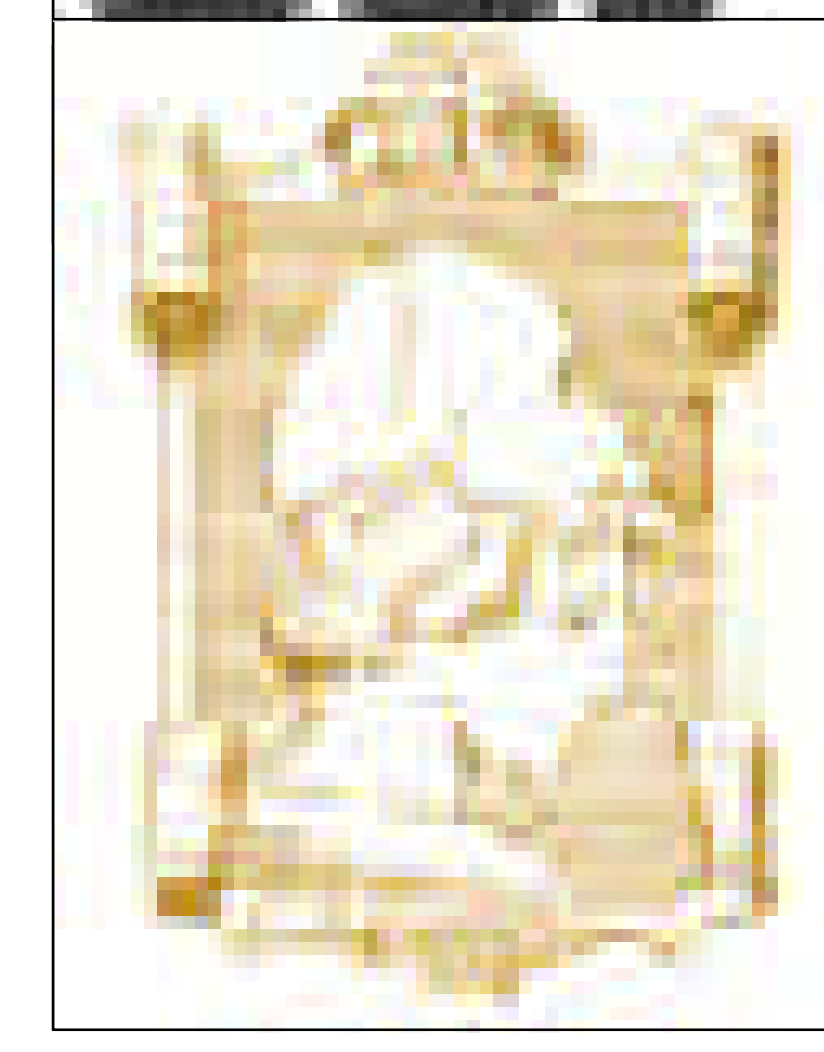

ANEXO VIII

Carta de Zoneamento Geoambiental $(1: 50.000)$

Autor: Holden Robson de Amorim Orientador: Prof. Dr. Osni José Pejon

Zona: 23 do Hemisfério Sul Datum Horizontal: Córego Alegre (MG) Elipsoide de Referência: SAD-69 $\quad$ Datum Vertical: Maregrafafo Imbituba (SC) 
ANEXO IX - RELAÇÃO ENTRE AS UNIDADES DE TERRENO E OS DIVERSOS ATRIBUTOS DO MEIO FÍSICO LEVANTADOS 

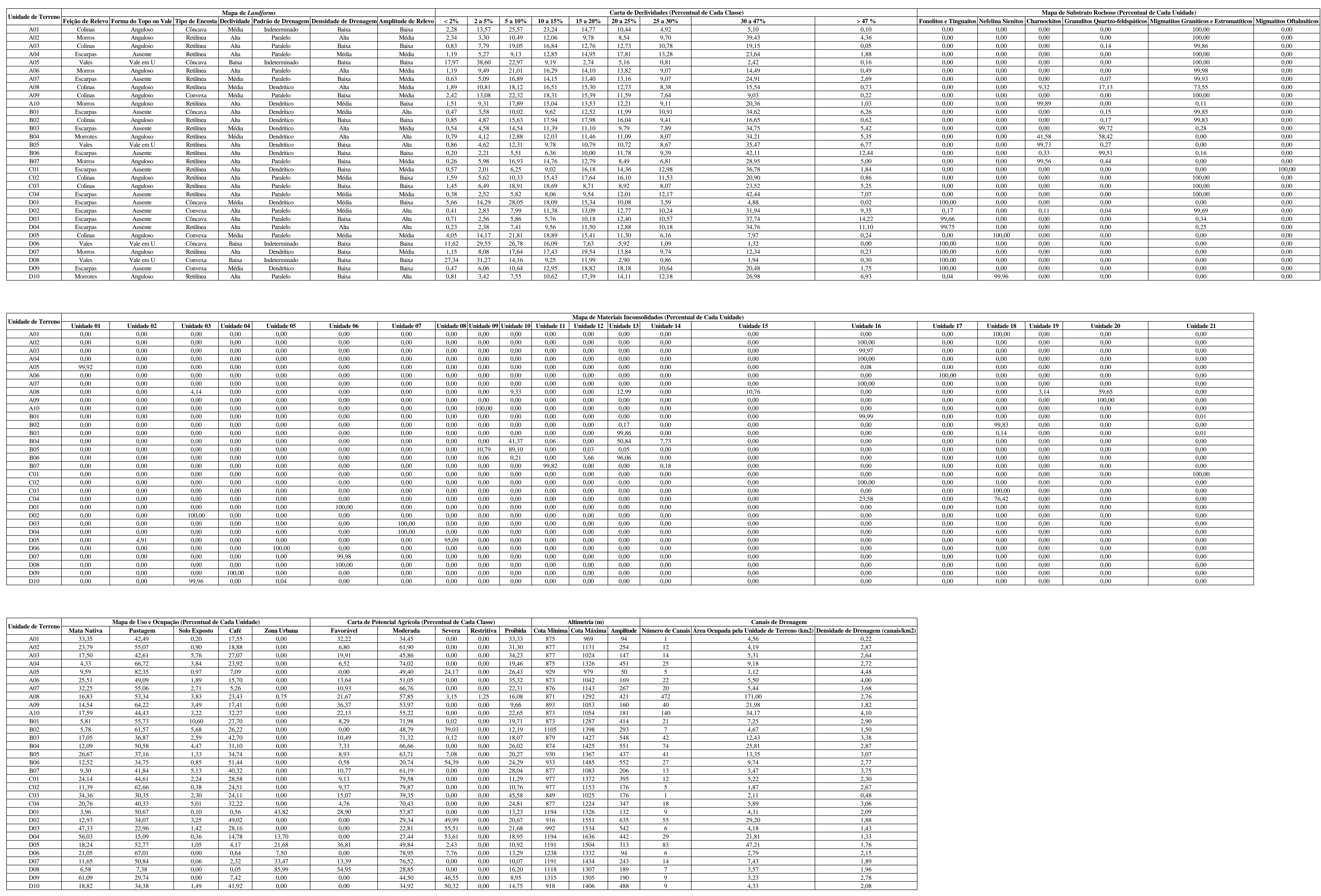


\section{ANEXO $X$ - RELAÇÃO ENTRE AS UNIDADES GEOAMBIENTAIS E OS DIVERSOS ATRIBUTOS DO MEIO FÍSICO LEVANTADOS}




\begin{tabular}{|c|c|c|c|c|c|c|c|c|c|c|c|}
\hline \multirow{2}{*}{ Unidades Geoambientais } & \multirow{2}{*}{ Feições de Relevo } & \multicolumn{9}{|c|}{ Carta de Declividades (Percentual de Cada Classe) } & \multirow{2}{*}{ Mapa de Substrato Rochoso (Percentual de Cada Unidade) } \\
\hline & & $<2 \%$ & 2 a 5\% & 5 a $10 \%$ & 10 a $15 \%$ & 15 a $20 \%$ & 20 a $25 \%$ & 25 a $30 \%$ & 30 a $47 \%$ & $>47 \%$ & \\
\hline Geo01 & Colinas & 1,54 & 8,67 & 20,24 & 20,22 & 14,97 & 12,46 & 7,36 & 13,28 & 1,27 & $\begin{array}{l}\text { Predomínio de Migmatitos Graníticos e Estromaútíticos }(99,93 \%) \text {. } \\
\end{array}$ \\
\hline Geo02 & Escarpas & 0,38 & 2,52 & 5,82 & 8,06 & 9,54 & 12,01 & 12,17 & 42,44 & 7,07 & Migmatitos Grańíticos e Estromatíticos $(100,00 \%)$. \\
\hline Geo03 & Morros & 1,19 & 9,49 & 21,01 & 16,29 & 14,10 & 13,82 & 9,07 & 14,49 & 0,49 & Predomínio de Migmatitos Graníticos e Estromátíticos $(99,98 \%)$. \\
\hline Geo04 & Colinas & 1,95 & 11,06 & 18,60 & 16,72 & 15,31 & 12,60 & 8,29 & 14,80 & 0,67 & 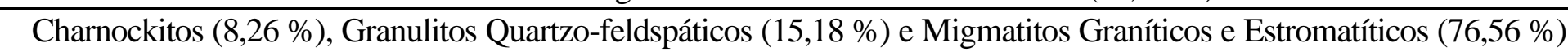 \\
\hline Geo05 & Morros, Escarpas e Colinas & 1,05 & 5,05 & 12,42 & 13,04 & 13,32 & 13,70 & 11,13 & 27,37 & 2,93 & $\begin{array}{l}\text { Predomínio de Migmatitos Graníticos e Estromaútíicos }(99,94 \%) . \\
\end{array}$ \\
\hline Geo06 & Vales & 17,98 & 38,63 & 22,98 & 9,19 & 2,74 & 5,16 & 0,81 & 2,34 & 0,16 & Migmatitos Graníticos e Estromatíticos $(100,00 \%)$. \\
\hline Geo07 & Escarpas & 0,41 & 2,83 & 7,99 & 11,38 & 13,09 & 12,77 & 10,24 & 31,94 & 9,35 & $\begin{array}{l}\text { Predomínio de Migmatitos Graníticos e Estromatúticos }(99,69 \%) \text {. }\end{array}$ \\
\hline Geo08 & Morrotes & 0,81 & 3,38 & 7,56 & 10,63 & 17,40 & 14,12 & 12,19 & 26,99 & 6,93 & Nefelina Sienitos $(100,00 \%)$ \\
\hline Geo09 & Morros & 1,51 & 9,31 & 17,89 & 15,04 & 13,53 & 12,21 & 9,11 & 20,36 & 1,03 & Predomínio de Charnockitos $(99,89 \%)$. \\
\hline Geo10 & Vales & 0,86 & 4,62 & 12,31 & 9,78 & 10,79 & 10,72 & 8,67 & 35,47 & 6,77 & Predomínio de Charnockitos $(99,73 \%)$. \\
\hline Geo11 & Morros & 0,26 & 5,98 & 16,93 & 14,76 & 12,79 & 8,49 & 6,81 & 28,95 & 5,00 & Predomínio de Charnockitos $(99,56 \%)$. \\
\hline Geo12 & Escarpas & 0,54 & 4,58 & 14,54 & 11,39 & 11,10 & 9,79 & 7,89 & 34,75 & 5,42 & Predomínio de Granulitos Quartzo-feldspáticos $(99,72 \%)$. \\
\hline Geo13 & Escarpas & 0,20 & 2,21 & 5,51 & 6,36 & 10,00 & 11,78 & 9,39 & 42,11 & 12,44 & Predomínio de Granulitos Quartzo-feldspáticos $(99,51 \%)$. \\
\hline Geo14 & Morrotes & 0,79 & 4,12 & 12,88 & 12,03 & 11,46 & 11,09 & 8,07 & 34,21 & 5,35 & Charnockitos $(41,58 \%)$ e Granulitos Quartzo-feldspáticos $(58,42 \%)$. \\
\hline Geo15 & Colinas & 4,05 & 14,17 & 21,81 & 18,89 & 15,41 & 11,30 & 6,16 & 7,97 & 0,24 & Nefelina Sienitos $(100,00 \%)$ \\
\hline Geo16 & Escarpas & 0,57 & 2,01 & 6,25 & 9,02 & 16,18 & 14,36 & 12,98 & 36,78 & 1,84 & Migmatitos Oftalmíticos $(100,00 \%)$. \\
\hline Geo17 & Escarpas e Morros & 2,80 & 10,36 & 21,46 & 17,68 & 18,00 & 12,46 & 7,48 & 9,60 & 0,15 & Fonolitos e Tinguátos $(100,00 \%)$. \\
\hline Geo18 & Vales & 27,34 & 31,27 & 14,16 & 9,25 & 11,99 & 2,90 & 0,86 & 1,94 & 0,30 & Fonolitos e Tinguátos $(100,00 \%)$. \\
\hline Geo19 & Vales & 11,62 & 29,55 & 26,78 & 16,09 & 7,63 & 5,92 & 1,09 & 1,32 & 0,00 & Fonolitos e Tinguátos $(100,00 \%)$. \\
\hline Geo20 & Escarpas & 0,31 & 2,41 & 7,16 & 8,95 & 11,29 & 12,80 & 10,24 & 35,24 & 11,60 & $\begin{array}{l}\text { Predomínio de Fonolitos e Tinguátos }(99,73 \%) \text {. } \\
\end{array}$ \\
\hline Geo21 & Escarpas & 0,47 & 6,11 & 10,64 & 12,94 & 18,81 & 18,17 & 10,64 & 20,47 & 1,75 & Fonolitos e Tinguátos $(100,00 \%)$ \\
\hline
\end{tabular}

\begin{tabular}{|c|c|}
\hline Unidades Geoambientais & Mapa de Materiais Inconsolidados (Percentual de Cada Unidade) \\
\hline Geo01 & Predominio da Unidade 18- Materiais residuais de migmatitos granniticos es estromantificos pertencentes a o grupo textural $\mathrm{V}(99,93 \%)$. \\
\hline Geo02 & 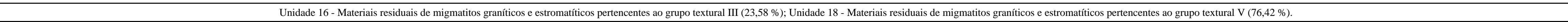 \\
\hline Geo03 & 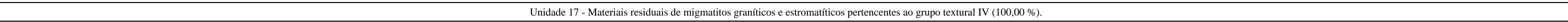 \\
\hline Geo04 & 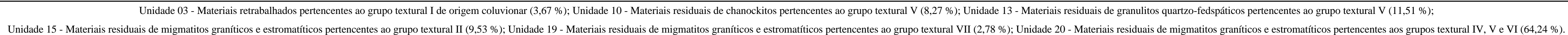 \\
\hline Geo05 & Predominio da Unidade 16 - Materiais residuais de migmatitios granniticos e estromatriticos pertencentes ao grupo textural III $99,99 \%$ \%). \\
\hline Geo06 & Unidade 01 - Materiais retrabalhados pertencentes ao grupo textural I de origem aluvionar $(100,00 \%)$. \\
\hline Ge007 & 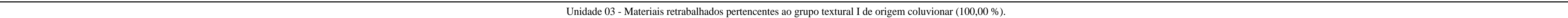 \\
\hline Geo08 & Unidade 03 - Materiais retrabalhados pertencentes a g grupo textural Id origem coluvionar $(100,00 \%$ \%). \\
\hline Geo09 & Unidade 09 - Materiais residuais de chanockitos pertencentes a a grupo textural III $(100,00 \%)$. \\
\hline Geol0 & Unidade 09 - Materiais residuais de c chanockitos pertencentes a a grupo textural III $(10,79 \%$ ); Unidade 10 - Materiais residuais de chanockitos pertencentes a a grupo textural V $(89,10 \%$ ). \\
\hline Geol1 & Predominio da Unidade 11 - Materiais residuais de chanockitos pertencentes ao grupo textural $\mathrm{VI}(99,82 \%)$. \\
\hline Geol2 & Predominio da Unidade 13 - Materiais residuais de granulitios quartzo-fedspaticos pertencentes a a grupo textural $\mathrm{V}(99,86 \%$ \%). \\
\hline Geo13 & 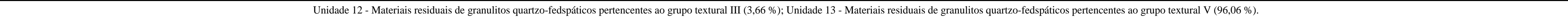 \\
\hline Geo14 & 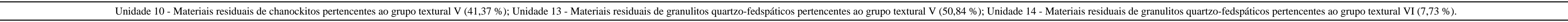 \\
\hline Geo15 & 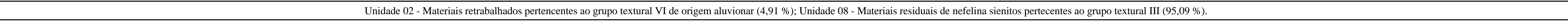 \\
\hline Geo16 & Unidade 21-Materiais residuais de migmantitos offalmiticicos pertencentes ao grupo textural III $(100,00 \%)$. \\
\hline Geol7 & Predominio da Unidade 06 - Materiais residuais de fonolitos e tinguatios pertecentes a a grupo textural VII $99,98 \%$ ). \\
\hline Geo18 & 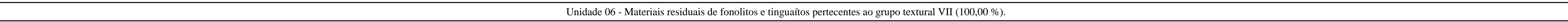 \\
\hline Geo19 & Unidade 05 - Materiais residuais de fonolitos e tinguaitos pertecentes ao grupo textural IV $(100,00 \%)$. \\
\hline Geo20 & Unidade 07 - Materiais residuais de fonolitios e tinguatitos pertecentes a a grupo textural $\mathrm{VIII}(100,00 \%)$. \\
\hline Geo21 & $\begin{array}{ll}\text { Predominio da Unidade } 04 \text { - Materiais residuais de fonolitios e tinguatitos pertecentes a a grupo textural III } 99,94 \% \text { ). } \\
\end{array}$ \\
\hline
\end{tabular}

\begin{tabular}{|c|c|c|c|c|c|c|c|c|c|c|c|c|c|c|c|c|}
\hline \multirow{2}{*}{ Unidades Geoambientais } & \multicolumn{5}{|c|}{ Mapa de Uso e Ocupação (Percentual de Cada Unidade) } & \multicolumn{5}{|c|}{ Carta de Potencial Agrícola (Percentual de Cada Classe) } & \multicolumn{3}{|c|}{ Altimetria $(\mathbf{m})$} & \multicolumn{3}{|c|}{\begin{tabular}{|c|} 
Canais de Drenagem \\
\end{tabular}} \\
\hline & Mata Nativa & Pastage! & Solo Exposto & Café & Zona Urbana & Favoráve & Moderada & Severa & Restritiviv & Proibida & Cota Mínim & Cota Máxim: & Amplitude & Número de Canais & Área da Unidade Geoambiental $(\mathbf{k m} 2)$ & Densidade de Drenagem (canais/km2) \\
\hline Geo01 & 22,18 & 48,09 & 2,85 & 22,34 & 0,00 & 15,77 & 41,26 & 16,07 & 0,00 & 26,90 & 849 & 1398 & 549 & 9 & 11,33 & 0,79 \\
\hline Geo02 & 20,76 & 40,33 & 5,01 & 32,22 & 0,00 & 4,76 & 70,43 & 0,00 & 0,00 & 24,81 & 874 & 1425 & 551 & 18 & 5,89 & 3,06 \\
\hline Geo03 & 25,51 & 49,09 & 1,89 & 15,70 & 0,00 & 13,64 & 51,05 & 0,00 & 0,00 & $\begin{array}{r}35,32 \\
\end{array}$ & 873 & 1042 & 169 & 22 & 5,50 & 4,00 \\
\hline Geo04 & 16,57 & 54,58 & 3,79 & 22,75 & 0,66 & 23,35 & 57,40 & 2,79 & 1,11 & 15,35 & 871 & 1292 & 421 & 512 & 192,98 & 2,65 \\
\hline Geo05 & 14,17 & 56,86 & 4,87 & 21,60 & 0,00 & 9,96 & 66,69 & 0,01 & 0,00 & 23,34 & 873 & 1326 & 453 & 97 & 33,23 & 2,92 \\
\hline Geo06 & 9,60 & 82,42 & 0,97 & 7,02 & 0,00 & 0,00 & 49,35 & 24,19 & 0,00 & 26,45 & 929 & 979 & 50 & 5 & 1,11 & 4,49 \\
\hline Geo07 & 12,93 & 34,07 & 3,25 & 49,02 & 0,00 & 0,00 & 29,34 & 49,99 & 0,00 & 20,67 & 919 & 1551 & 632 & 55 & 29,20 & 1,88 \\
\hline Geo08 & 18,83 & 34,36 & 1,49 & 41,93 & 0,00 & 0,00 & 34,90 & 50,34 & 0,00 & 14,76 & 918 & 1406 & 488 & 9 & 4,33 & 2,08 \\
\hline Geo09 & 17,59 & 44,43 & 3,22 & 32,27 & 0,00 & 22,13 & 55,22 & 0,00 & 0,00 & 22,65 & 873 & 1054 & 181 & 140 & 34,17 & 4,10 \\
\hline Geo10 & 26,67 & 37,16 & 1,33 & 34,74 & 0,00 & 8,93 & 63,71 & 7,08 & 0,00 & 20,27 & 930 & 1367 & 4377 & 41 & 13,35 & 3,07 \\
\hline Geol1 & 9,30 & 41,84 & 5,13 & 40,32 & 0,00 & 10,77 & 61,19 & 0,00 & 0,00 & 28,04 & 877 & 1083 & 206 & 13 & 3,47 & 3,75 \\
\hline Geol2 & 17,00 & 36,87 & 2,59 & 42,70 & 0,00 & 10,49 & 71,32 & 0,12 & 0,00 & 18,07 & 879 & 1427 & 548 & 42 & 12,43 & 3,38 \\
\hline Geo13 & 12,52 & 34,75 & 0,85 & 51,44 & 0,00 & 0,58 & 20,74 & 54,39 & 0,00 & 24,29 & 933 & 1485 & 552 & 27 & 9,74 & 2,77 \\
\hline Geol4 & 12,09 & 50,58 & 4,47 & 31,10 & 0,00 & 7,33 & 66,6 & 0,00 & 0,00 & 26,02 & 874 & 1425 & 551 & 74 & 25,81 & 2,87 \\
\hline Geo15 & 18,24 & 52,77 & 1,05 & 4,17 & 21,68 & 36,81 & 49,84 & 2,43 & 0,00 & 10,92 & 1191 & 1504 & 313 & 83 & 47,21 & 1,76 \\
\hline Geo16 & 24,14 & 44,61 & 2,24 & 28,58 & 0,00 & 9,13 & 79,58 & 0,00 & 0,00 & 11,29 & 977 & 1372 & 395 & 12 & 5,22 & 2,30 \\
\hline Geol7 & 8,83 & 50,78 & 0,08 & 1,68 & 37,27 & 19,09 & 69,67 & 0,00 & 0,00 & 11,23 & 1191 & 1434 & 243 & 23 & 11,73 & 1,96 \\
\hline Geo18 & 6,58 & 7,38 & 0,00 & 0,05 & 85,99 & 54,95 & 28,85 & 0,00 & 0,00 & 16,20 & 1118 & 1307 & 189 & 7 & 3,57 & 1,96 \\
\hline Geo19 & 21,00 & 67,01 & 0,00 & 0,64 & 7,50 & 0,00 & 78,95 & 7,76 & 0,00 & 13,29 & 1238 & 1332 & 94 & 6 & 2,79 & 2,15 \\
\hline Geo20 & 54,63 & 16,36 & 0,53 & 16,93 & 11,49 & 0,00 & 26,70 & 53,91 & 0,00 & 19,39 & 992 & 1636 & 644 & 35 & 26,00 & 1,35 \\
\hline Geo21 & 61,06 & 29,78 & 0,00 & 7,42 & 0,00 & 0,00 & 44,53 & 46.53 & 0.00 & 8,94 & 918 & 1406 & 488 & 9 & 3,23 & 2.78 \\
\hline
\end{tabular}

